\title{
The impact of brands on innovation and firm performance : empirical evidence from Germany
}

Citation for published version (APA):

Crass, D. (2014). The impact of brands on innovation and firm performance : empirical evidence from Germany. [Doctoral Thesis, Maastricht University]. Maastricht University. https://doi.org/10.26481/dis.20141217dc

Document status and date:

Published: 01/01/2014

DOI:

$10.26481 /$ dis.20141217dc

Document Version:

Publisher's PDF, also known as Version of record

\section{Please check the document version of this publication:}

- A submitted manuscript is the version of the article upon submission and before peer-review. There can be important differences between the submitted version and the official published version of record.

People interested in the research are advised to contact the author for the final version of the publication, or visit the DOI to the publisher's website.

- The final author version and the galley proof are versions of the publication after peer review.

- The final published version features the final layout of the paper including the volume, issue and page numbers.

Link to publication

\footnotetext{
General rights rights.

- You may freely distribute the URL identifying the publication in the public portal. please follow below link for the End User Agreement:

www.umlib.nl/taverne-license

Take down policy

If you believe that this document breaches copyright please contact us at:

repository@maastrichtuniversity.nl

providing details and we will investigate your claim.
}

Copyright and moral rights for the publications made accessible in the public portal are retained by the authors and/or other copyright owners and it is a condition of accessing publications that users recognise and abide by the legal requirements associated with these

- Users may download and print one copy of any publication from the public portal for the purpose of private study or research.

- You may not further distribute the material or use it for any profit-making activity or commercial gain

If the publication is distributed under the terms of Article $25 \mathrm{fa}$ of the Dutch Copyright Act, indicated by the "Taverne" license above, 


\section{The Impact of Brands on Innovation and Firm Performance}

Empirical Evidence from Germany

\section{Dirk Crass}





\section{The Impact of Brands}

on Innovation and Firm Performance -

Empirical Evidence from Germany 
(C) Dirk Crass, Maastricht 2014

All rights reserved. No part of this publication may be reproduced, stored in a retrieval system, or transmitted in any form, or by any means, electronic, mechanical, photocopying, recording or otherwise, without the prior permission in writing from the author.

Published by Universitaire Pers Maastricht

ISBN: 9789461593979

Printed in The Netherlands by Datawyse Maastricht 


\title{
The Impact of Brands \\ on Innovation and Firm Performance - Empirical Evidence from Germany
}

\author{
DISSERTATION \\ to obtain the degree of Doctor at Maastricht University, \\ on the authority of the Rector Magnificus Prof. Dr. L. L. G. Soete \\ in accordance with the decision of the Board of Deans, \\ to be defended in public on Wednesday December $17^{\text {th }} 2014$, at $15: 45$ hours
}

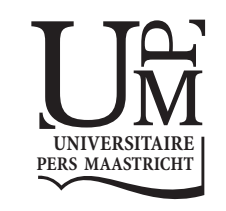


Supervisor:

Prof. Dr. Pierre Mohnen

Co-supervisor:

Dr. Bettina Peters (ZEW Mannheim, Germany)

\author{
Assesment Committee: \\ Prof. Dr. John Hagedoorn (Chairperson) \\ Prof. Dr. Martin A. Carree \\ Prof. Dr. Can Huang (Zhejiang University, Hangzhou, China) \\ Prof. Dr. Katrin Hussinger (University of Luxembourg)
}


To my mum and dad. Thanks for always being there for me.

To my wife Sarah. Thank you for all of your love, support, help, encouragement and dedication. I am so grateful that you are an integral part of my life.

To our son Lennard, who recognised the tiny little symbols on our clothes. Thank you for the excitement and laughter about brands at our breakfast table.

This is a tribute to all of you. 



\section{Acknowledgements}

I particularly thank my supervisors, Prof. Pierre Mohnen and Dr. Bettina Peters, for their time discussing my work, their guiding questions, and their valuable suggestions for the improvement of my papers. I would like to thank the reading committee, John Hagedoorn, Martin Carree, Can Huang and Katrin Hussinger, for their time and careful reading of the manuscript. I also express my gratitude to my co-authors Dirk Czarnitzki, Andrew A. Toole, and Bettina Peters for their long-term support. Furthermore, I would like to thank Prof. Jonathan Haskel for his invitation to visit the Imperial College Business School London in early autumn 2011 and Prof. Brent Goldfarb for his invitation to visit the University of Maryland's Robert H. Smith School of Business in autumn 2012. Both research stays provided me with great insights and were wonderful experiences in many aspects.

The working atmosphere at the Department of Industrial Economics and International Management in particular, and at the ZEW in Mannheim in general, is a very pleasant and inspiring one. My thanks and appreciations go to Georg Licht and all my colleagues for their support and encouragement. Although I should mention all colleagues, I would like to provide special thanks to Thorsten Doherr, Christian Rammer and Paula Schliessler. Thank you all for your feedback and advice which certainly helped in improving the research quality of my individual working papers. 



\section{Contents}

List of Figures $\quad$ v

List of Tables vii

$\begin{array}{lll}\text { Summary } & \text { i }\end{array}$

Samenvatting $\quad$ iii

1 Introduction 1

1.1 Background and Motivation . . . . . . . . . . . . . . . 1

1.2 Research Questions and Main Results . . . . . . . . . . . . . . . . . 3

1.3 Thesis Outline . . . . . . . . . . . . . . . . . . 5

2 Which Firms Use Trademarks - and Why? Representative Firm$\begin{array}{ll}\text { Level Evidence from Germany } & 7\end{array}$

2.1 Introduction . . . . . . . . . . . . . . . . . . . 7

2.2 The Role of Trademarks . . . . . . . . . . . . . . . . . . . . . . . . 9

2.2.1 The Reputation of Trademarks . . . . . . . . . . . . . . 9

2.2.2 The Link between Innovation and Trademarks . . . . . . . . . 11

2.3 Empirical Implementation . . . . . . . . . . . . . . . . . . . . . . 12

2.3.1 Data Sets . . . . . . . . . . . . . . . . . . 12

2.3.2 Trademarking Firms . . . . . . . . . . . . . . . . . . . . 13

2.3.3 Explanatory Variables . . . . . . . . . . . . . . . . 16

2.4 Empirical Findings . . . . . . . . . . . . . . . . . . . . . . . . . 19

2.4.1 The Propensity to Trademark . . . . . . . . . . . . . . . . 19

2.4.2 Distance, product quality and substitutability matters . . . . 21

2.4 .3 Innovation matters . . . . . . . . . . . . . . . . . . . 23

2.5 Conclusion . . . . . . . . . . . . . . . . . . . . . . . 25

2.A Appendix . . . . . . . . . . . . . . . . . . 27

2.A.1 Definition of Variables . . . . . . . . . . . . . . 27

2.A.2 Descriptive Statistics . . . . . . . . . . . . . . . . 28

2.A.3 Descriptive Statistics . . . . . . . . . . . . . . . . . . . . 29

2.A.4 Correlation Matrix . . . . . . . . . . . . . . . 30

2.A.5 Weighted Regression . . . . . . . . . . . . . . . 32 
3 The Impact of Brand Use on Innovation Performance - Empirical Results for Germany 33

3.1 Introduction . . . . . . . . . . . . . . . . . . . 33

3.2 Determinants of Innovation Performance . . . . . . . . . . . . . . 35

3.2 .1 Investment in Innovation . . . . . . . . . . . . . . . 35

3.2 .2 Brand Use . . . . . . . . . . . . . . . . . . . 37

3.3 Data and Variables . . . . . . . . . . . . . . . . . . . . 38

3.3.1 Data Sets . . . . . . . . . . . . . . . . . . 38

3.3.2 Product Innovation Performance . . . . . . . . . . . . . . . . 39

3.3.3 The Use of Brands for Product Innovations . . . . . . . . . . 40

3.3.4 Control variables . . . . . . . . . . . . . . . . . . . . . 41

3.4 Empirical Strategy and Results . . . . . . . . . . . . . . . . . . . 44

3.4.1 Impact of Brand Use on Innovation . . . . . . . . . . . . . . 45

3.4.2 Impact of Brand Use by Degree of Innovation . . . . . . . . . 48

3.4.3 Impact of Brand Use by Firm Size . . . . . . . . . . . . . . . 50

3.4.4 Robustness Check . . . . . . . . . . . . . . . . . 53

3.5 Concluding Remarks . . . . . . . . . . . . . . . . . . . . . 53

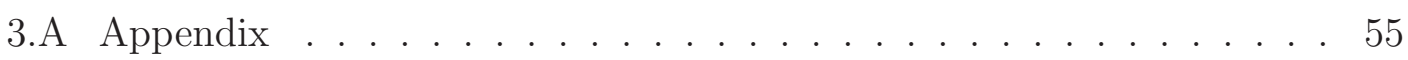

3.A.1 Definition of Variables . . . . . . . . . . . . . . 55

3.A.2 Descriptive Statistics . . . . . . . . . . . . . . . . 57

3.A.3 Innovation Performance: Robustness Check . . . . . . . . . 59

4 The Dynamic Relationship between Investments in Brand Equity and Firm Profitability: Evidence using Trademark Registrations 61

4.1 Introduction . . . . . . . . . . . . . . . . . . . . . . . . 61

4.2 Prior Literature and Conceptual Framework . . . . . . . . . . . . . . 62

4.2.1 Brand Investments and Brand Equity . . . . . . . . . . . . . 62

4.2.2 Brand Equity and Firm Profitability . . . . . . . . . . . . . 64

4.3 Data and Estimation Method . . . . . . . . . . . . . . . 67

4.3 .1 Data . . . . . . . . . . . . . . . 67

4.3.2 Dependent Variable: Firm Profitability . . . . . . . . . . . 67

4.3.3 The Trademark Measure of Brand Equity . . . . . . . . . . . 68

4.3.4 Empirical Implementation . . . . . . . . . . . . . . . . 70

4.3.5 Control Variables . . . . . . . . . . . . . . . . . . . 71

4.4 Econometric Results . . . . . . . . . . . . . . . . . . . . . . 72

4.5 Conclusion . . . . . . . . . . . . . . . . . . . . . . . 78

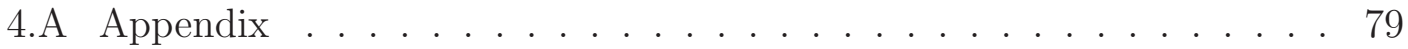

4.A.1 Definition of Variables . . . . . . . . . . . . . . . 79

4.A.2 Correlation Matrix . . . . . . . . . . . . . . 80 
5 Intangible Assets and Firm-Level Productivity 83

5.1 Introduction . . . . . . . . . . . . . . . . . . . . . . . 83

5.2 Productivity Effects of Intangible Assets . . . . . . . . . . . . . . . 85

5.3 Econometric Framework . . . . . . . . . . . . . . . . . . . . . 89

5.4 Data and Variables . . . . . . . . . . . . . . . . . . . . . . . . . 90

5.4 .1 Data . . . . . . . . . . . . . . . . . 90

5.4 .2 Variables. . . . . . . . . . . . . . . . . . . . 91

5.5 Stylized Facts on Firm-Level Investments in Intangibles . . . . . . . . 94

5.6 Econometric Results . . . . . . . . . . . . . . . . . . . . . . . . 97

5.6.1 Estimation Method . . . . . . . . . . . . . 97

5.6.2 Effect of Intangibles on Productivity . . . . . . . . . . . . . . 98

5.6.3 Robustness Checks . . . . . . . . . . . . . . . . 100

5.6.4 The Role of Organizational Investment on Productivity . . . . 106

5.6.5 Complementarity Between Intangible Assets . . . . . . . . . . 108

5.7 Conclusion . . . . . . . . . . . . . . . . . . . . . . . . . 110

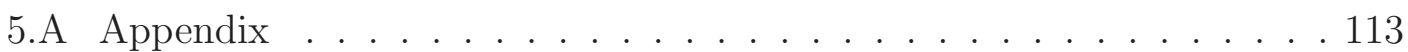

5.A.1 Definition of Variables . . . . . . . . . . . . . . . 113

5.A.2 Depreciation and Growth Rates . . . . . . . . . . . . . . . . 114

5.A.3 Correlation Matrix . . . . . . . . . . . . . . . . . . . . . . 114

5.A.4 Testing for Complementarity . . . . . . . . . . . . . . 116

5.A.5 Industry Differences . . . . . . . . . . . . . . . . 117

6 Concluding Discussion $\quad 119$

6.1 Overall Summary . . . . . . . . . . . . . . . . . . . . . . 119

6.2 Limitations and Future Research . . . . . . . . . . . . . . . . 121

$\begin{array}{llr}7 & \text { Bibliography } & 123\end{array}$

$\begin{array}{ll}\text { Valorization } & 135\end{array}$

$\begin{array}{lr}\text { Curriculum Vitae } & 139\end{array}$ 



\section{List of Figures}

2.1 Firm Size: a) Average Adjusted Predictions (AAPs), b) Average Marginal Effects (AMEs) . . . . . . . . . . . . . . 21

2.2 Distance to Customers matters, Adjusted Predictions at Representative Values (APRs) . . . . . . . . . . . . . . . . . . 22

2.3 Substitutability matters, Average Adjusted Predictions (AAPs) . . . 23

2.4 Innovation matters, Average Adjusted Predictions (AAPs) . . . . . . 24

4.1 Distribution of Firm Profitability . . . . . . . . . . . . . . 68

4.2 Age Distribution of Trademarks in 2010 . . . . . . . . . . . . . . . . 69

4.3 Lag-distributed Marginal Effects of Brand-related Investments . . . . 77 



\section{List of Tables}

2.1 Absolute Number and Proportion of Trademarking Firms in Germany 15

2.2 Descriptive Statistics of Main Variables (not weighted) . . . . . . . . 16

2.3 Firm Characteristics and the Propensity to Trademark . . . . . . . . 20

2.4 Variable Definitions . . . . . . . . . . . . . . . . . . . . 27

2.5 Descriptive Statistics of Main Variables (Part 1) . . . . . . . . . . . 28

2.6 Descriptive Statistics of Main Variables (Part 2) . . . . . . . . . . . . 29

2.7 Correlation Matrix . . . . . . . . . . . . . . . . . . . . . . 30

2.8 Weighted Regression: The Propensity to Trademark . . . . . . . . . . 31

3.1 Brand Usage of Product Innovators . . . . . . . . . . . . . . . . . . . 40

3.2 Descriptive Statistics of Main Variables . . . . . . . . . . . . . . . 43

3.3 The Propensity to Innovate and Determinants of Innovation Perfor-

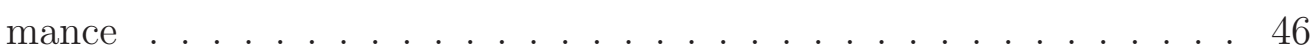

3.4 The Propensity to Innovate and Determinants of Innovation Performance . . . . . . . . . . . . . . . . . . . . . . 49

3.5 Split Sample: Differences Between Small and Larger Firms . . . . . . 52

3.6 Definitions of Main Variables _. . . . . . . . . . . . . . . 55

3.7 Variable Definitions (continued) . . . . . . . . . . . . 56

3.8 Descriptive Statistics of Main Variables . . . . . . . . . . . . . . . 57

3.9 Split Sample: Differences between smaller and larger firms . . . . . . 58

3.10 Innovation Success: Sales Share with Innovations . . . . . . . . . . . 59

4.1 Descriptive Statistics of Main Variables . . . . . . . . . . . . . . 72

4.2 Firm Profitability and the Impact of Brand-related Investments . . . 74

4.3 Resulting Betas (Random-Effects Interval Regression) . . . . . . . . . 76

4.4 Variable Definitions . . . . . . . . . . . . . . . . . . . . . . . . . 79

4.5 Correlation Matrix . . . . . . . . . . . . . . . . . . . . 80

4.6 Pooled vs. Panel Interval Regression . . . . . . . . . . . . . . . . 81

5.1 Proportion of Firms with Intangibles by Industries . . . . . . . . . . . 94

5.2 Descriptive Statistics of Main Variables . . . . . . . . . . . . . . . 96

5.3 Differences in Firm Productivity by Intangible Assets . . . . . . . . . 97

5.4 Effect of Intangibles on Firm-Level Productivity (TFP) . . . . . . . . 99 
5.5 Robustness Check: Parametric and Non-Parametric Estimation Methods . . . . . . . . . . . . . . . . . . . . . . 101

5.6 Robustness Check: Labour Productivity vs. TFP . . . . . . . . . . . 103

5.7 Robustness Check: Value Added . . . . . . . . . . . . . . . . . . . . 104

5.8 Intangibles Proxied by Expenses versus PIM Capital Stocks . . . . 106

5.9 Effect of Organizational Investment on Firm-Level Productivity . . . 107

5.10 Complementarities and Substitutabilities . . . . . . . . . . . . . 110

5.11 Complementarity and Substitutability Between Intangibles . . . . . . 111

5.12 Description and Definition of Main Variables . . . . . . . . . . . . . . 113

5.13 Depreciation- and Growth Rates for Intangibles . . . . . . . . . . . . 114

5.14 Correlation Coefficients of Intangibles (Dummy-Variables) . . . . . . 114

5.15 Correlation Matrix . . . . . . . . . . . . . . . . . . . . . . 115

5.16 Effect of Intangibles on Firm-Level Productivity: 1st Stage . . . . . . 117

5.17 Effect of Intangibles on Firm-Level Productivity: 2nd Stage . . . . . 118 


\section{Summary}

Brands belong to the most valuable intangible assets a firm can have. An established brand generates awareness and attention to a firm's branded products, adds reputation and credibility and favorable associations (Keller and Lehmann, 2006). Firm's that introduce product innovation may benefit in particular from the reputation of their brands (Aaker, 2007). The building of a brand takes, however, time and is associated with substantial investments. Whether a firm can expect a net gain from investments in brands is a priori not clear.

The research presented in this dissertation explores the impact of brands on innovation and firm performance. The empirical studies rely on the Mannheim Innovation Panel (MIP) which constitutes the German part of the international harmonized Community Innovation Survey (CIS). These surveys are representative for German firms and thus contain many small and medium-sized firms. Most of these firms are not required to publish any data. The inclusion of these firms constitutes an important difference to several existing studies. Existing studies which rely on publicly available firm level information, use most likely a selective sample of large firms which are not representative of the economy. The studies of this dissertation overcome this limitation and fill a gap in the literature as the findings are not related to large and famous global brands, but investigate the role of brands for a representative sample of German firms.

Brands can be protected by trademarks, but the majority of firms does not register trademarks at all. Extrapolated figures for the use of trademark registrations, which are representative for all German firms with more than five employees, show that about $18 \%$ of firms have at least one registered trademark. Based on this finding, Chapter 2 proceeds with the question of which factors drive firms' decision to register trademarks. The empirical analysis shows that the probability to register trademarks is higher if firms are larger, have to overcome the distance to their customers, differentiate their products against those from competitors, and that product innovations in particular are associated to the use of trademarks.

Based on the finding that the trademark registration of a firm is associated with its product innovations, Chapter 3 investigates the question of whether the use of brands has a positive impact on the commercial success of a firm's product innovations. Firms can use a brand to introduce a product innovation into the market. A brand 
name might generate interest, adds credibility and reputation. The results show that firms can improve the odds of commercial success by using a brand. The market introduction under an established brand is shown to be associated with about $35 \%$ larger sales with product innovations.

While the use of brands and trademarks is associated with higher firm performance in terms of higher sales, the net gain of investments in brand capital is not clear. Chapter 4 demonstrates empirically that past brand-related investments contribute to current profits. Brand-related investments are proxied by the flow of trademark registrations over the past thirty years. The results show that it takes on average four years until brand-related investments show a positive return, and twelve years until their return peaks. After that the effect slowly fades out and investments older than twenty-three years show no significant impact anymore.

The last study compares the effect of different types of intangible assets on productivity and sheds light on the question of whether complementarity exists between them. Intangible assets include a comprehensive set of components, which are grouped into three main categories: innovative capital, human capital, and branding capital. A firm's branding capital, measured in terms of marketing expenditures and registered trademarks, is shown to have a strong positive impact on total factor productivity. The study provides also evidence that innovative capital and branding capital are complements. 


\section{Samenvatting}

Een merk is een van de meest waardevolle zaken dat een bedrijf kan bezitten. Een gevestigd merk creëert bewustzijn en aandacht voor producten, bouwt reputatie en geloofwaardigheid op, en creëert gunstige associaties (Keller and Lehmann, 2006). Aan de andere kant vergt het opbouwen van een merk veel tijd en substantiele investeringen. Het is dus a priori niet duidelijk of een firma een netto-opbrengst kan verwachten van merkinvesteringen.

Deze thesis onderzoekt de impact van merken op innovatie en bedrijfsprestaties. De empirische studies zijn gebaseerd op het Duitse deel van de Community Innovation Survey (CIS). Deze enqutes zijn respresentatief voor Duitse bedrijven, en bevatten ook veel kleine en middelgrote bedrijven. Een belangrijk verschil met andere studies is dat de meeste van deze bedrijven niet verplicht zijn om gegevens te publiceren. Andere studies gebaseerd op publieke bedrijfsinformatie gebruiken dus waarschijnlijk een selectieve steekproef van grote bedrijven die niet representatief is voor de hele economie. De studies in deze dissertatie vermijden deze beperking. De bevindingen zijn dus niet enkel relevant voor wereldwijd bekende merken, maar respresenteren in de plaats de rol van merken voor een representatieve steekproef van Duitse bedrijven. Merken kunnen door handelsmerken beschermd worden, maar de meerderheid van bedrijven registreert geen enkel handelsmerk. Hoofdstuk 2 bevat geextrapoleerde gegevens voor het gebruik van handelsrechtregistraties die representatief zijn voor alle Duitse bedrijven met meer dan vijf werknemers. De resultaten geven aan dat ongeveer $18 \%$ van de firmas op zijn minst 1 geregistreerd handelsmerk heeft. De empirische analyse toont aan dat the waarschijnlijkheid dat een handelsmerk geregistreerd wordt groter is als de bedrijven groter zijn, de afstand tot hun klanten moeten overbruggen, hun producten differentiëren van die van hun concurrenten, en dat productinnovatoren specifiek geassocieerd worden met het gebruik van handelsmerken.

Bedrijven kunnen een merk gebruiken om een productinnovatie in de markt te introduceren. Een merknaam kann interesse genereren, en credibiliteit en reputatie opbouwen. Hoofdstuk 3 onderzoekt de rol van het gebruik van merken voor het commercieel succes van productinnovaties. De resultaten geven aan dat bedrijven de kansen op commercieel succes kunnen verbeteren door een merkstrategie na te streven. Een marktintroductie onder een gevestigd merk is geassocieerd met $35 \%$ 
hogere verkoop met productinnovaties.

Terwijl het gebruik van merken en handelsmerken geassocieerd wordt met bedrijfsperformantie, is de netto-opbrengst van investeringen in merkkapitaal niet duidelijk. Hoofdstuk 4 demonstreert door empirische analyse dat merkgerelateerde investeringen in het verleden bijdragen tot huidige winst. Merkgerelateerde investeringen worden benaderd door de stroom van handelsmerkregistraties van de laatste dertig jaar. De resultaten geven aan dat het gemiddeld vier jaar duurt voor merkgerelateerde investeringen een positief rendement genereren, en twaalf jaar voordat het rendement piekt. Investeringen ouder dan drieëntwintig jaar hebben geen significante impact meer.

De laatste studie, gepresenteerd in hoofdstuk 5, onderzoekt de impact van immateriële activa op productiviteit. Immateriële activa bevatten een uitgebreide set van componenten, die in drie categorieën zijn ingedeeld: innovatief kapitaal, menselijk kapitaal, en merkkapitaal. Er wordt aangetoond dat het merkkapitaal van een firma, gemeten aan de hand van marketinguitgaven en geregistreerde handelsmerken, een sterke positieve impact heeft op totale factorproductiviteit. De studie bewijst ook dat innovatief kapitaal en merkkapitaal complementair werken. 


\section{Chapter 1}

\section{Introduction}

\subsection{Background and Motivation}

Brands have a ubiquitous presence throughout the economy and in our everyday life. This has its advantages. They enable consumers to identify and memorise products, to determine their origin, and to distinguish products of different providers from each other (Aaker, 1991). The identifiability of a product is an essential requirement for customers to draw on previous experiences with a product while making purchasing decisions. The experiences with the product, even those of others, may prove useful to evaluate otherwise unobservable product characteristics. The evaluation of a product enables customers to assess (i) how functional or effective the product is, (ii) how reliable it is, (iii) how durable it is, (iv) how easy it is to use, (v) how it tastes, sounds or smells and (vi) what side effects it may have (WIPO, 2013, p.81). Positive experiences are likely to lead to repeated purchases, while disappointed customers might avoid the product. This constitutes an incentive for firms to build a reputation to deliver products and services of a reliable quality, leading to the quality guarantee, implicitly indicated by trademarks. In turn, producers are able to differentiate their products against those of competitors and to establish brand reputation.

An established brand is one of the most valuable intangible asset a firm can have and, following Barney (1991), serves as a firm's key competitive advantage. Barney (1991) argues that a sustained competitive advantage depends on a firm's resources and capabilities that are valuable, rare, imperfectly imitable, and not substitutable. An established brand definitely falls into this category. A brand can develop qualities that exist above and beyond the objective product or service such as customer awareness, perception of desirable overall quality, and favorable associations (Keller and Lehmann, 2006). The direct effect of branding capital is that brand loyalty is created and the demand for the brand becomes less price-elastic (Schmalensee, 1982; Bagwell, 2007).

A brand is of economic value only if the respective firm has the right to use this 
reputational asset exclusively. In Germany there are two ways of getting exclusive rights of marks. First, the protection of marks might be obtained on the basis of use in commerce. Protection is awarded if the mark is used intensively in commerce and a significant proportion of the relevant public has knowledge of the mark. A formal registration does not take place; trademarks acquired by use are therefore not observable by the researcher. There are good reasons for firms not to rely solely on the protection acquired by use and to choose the second way to obtain the exclusive right on a mark: the official registration. The registration of a trademark offers a number of advantages: (i) A trademark is protected once it is registered $;^{1}$ knowledge of the relevant public is not necessary. (ii) The scope of protection includes the selected product and service classes and applies to the whole territory of Germany; protection is not limited to the region in which the relevant public has knowledge of the mark. (iii) Registration takes place at reasonable cost: the basic registration fee at the German trade mark office (DPMA) amounts to 290 Euro and at the European Office (OHIM) to 900 Euro, possibly augmented by attorneys fees.

The European law (Article 2, Directive 2008/95/EC of the European Parliament and of the Council) defines a trademark as follows: "A trade mark may consist of any signs capable of being represented graphically, particularly words, including personal names, designs, letters, numerals, the shape of goods or of their packaging, provided that such signs are capable of distinguishing the goods or services of one undertaking from those of other undertakings." A firm might use a bundle of trademarks to protect different aspects of the representation of its brand. The Coca-Cola brand, for example, is one of the most valuable brands world-wide and protected in Germany by a rich bundle of over 100 trademarks. These trademarks protect the word CocaCola, the figure of the distinctive lettering, the famous "waisted" bottle shape, as well as several marketing slogans.

The registration of a brand as a trademark or through a bundle of trademarks protects the reputation of a brand. The registration defines a firm's rights against counterfeiting and fraud. The owner of this right is given a legal monopoly over the protected word, sign, symbol or other graphical representation in connection with the attached commodity. The owner has the exclusive right to commercially use the protected trademark and is exclusively protected against infringement (Economides, 1998; Baroncelli et al., 2004). The protection from misuse happens not automatically; the trademarking firm has to proactively police for trademark violations and enforce its rights against infringement. Von Graevenitz (2007) emphasizes that trademark owners need the "reputation of being tough on imitators".

For this thesis trademark application data have been prepared and merged to firmlevel data. In contrast to the US, where the US Patent and Trademark Office (USPTO) released a dataset of trademark applications in a format convenient for

\footnotetext{
${ }^{1}$ The term trademark refers to the legal right that belongs to the wider family of intellectual property rights.
} 
researchers (Graham et al., 2013), the German and European trademark data needed extensive data processing. The preparation of the administrative data started with the extraction of variables from the raw data and led to a panel of trademark portfolios at the firm-level. The resulting dataset provides detailed information on a firm's trademark applications filed with, or registrations issued by, the German Patent and Trademark Office (DPMA) and the Office for Harmonization in the Internal Market (OHIM). The data set provides information on ownership, mark characteristics, protection classes, opposition proceedings, and renewal and maintenance history on about 1.7 million German trademarks since 1875 and on about 1 million Community trademarks since the foundation of OHIM in 1996.

Firm-level data is obtained from the Mannheim Innovation Panel (MIP) which is a stratified random sample (stratified by sector, size and region) of German firms. The MIP is the German contribution to the European-wide harmonized Community Innovation Surveys (CIS) and based on the concepts and definitions of OECD's Oslo Manual (2005) for collecting data on innovation processes and targets legally independent firms with at least five employees. The survey is voluntary in Germany and each year between 5000 and 7000 enterprises in manufacturing and services respond to the survey and provide information on their innovation activities and general firm information such as sales, employment, exports, and other major control variables. The design of the MIP offers some flexibility to introduce additional questions. In the 2011 survey, this flexibility has been used to ask firms about their brand use, their branding policy and about the role of brands in their innovation strategy. The 2011 questionnaires had been returned by nearly 7,000 firms in manufacturing and services, which constituted a $20 \%$ response rate.

Surveyed MIP firms have been linked with information on firm's trademark activity at the German Patent and Trademark Office (DPMA) and at the Office of Harmonization for the Internal Market (OHIM). Firm-specific trademark information were collected by matching the name of the firms participating in the innovation survey with the names of applicants at the OHIM and the DPMA using a special software developed at ZEW, and including an extensive manual double-check.

\subsection{Research Questions and Main Results}

\section{Which firms use trademarks - and why?}

In a recent survey Schautschick and Greenhalgh (2013) conclude that trademarking firms are more productive (see Chapter 5), generate higher profits (see Chapter 4), and have a better survival rate. Trademarking firms are in one word more successful, which should motivate non-trademarking firms to adopt a trademark strategy. But this does not seem not to be the case. Chapter 2 provides empirical evidence that the proportion of trademarking firms in the German business sector amounts 
to just $18 \%$. This figure is quite low, given that nearly each firm has its reputation to protect. The first research question addressed in this thesis is, therefore, why the vast majority of firms has no registered trademarks. The purpose of chapter 2 is to shed more light on firm and product characteristics that influence a firm's decision to trademark. Using a representative sample of German firms, this chapter provides projections about the use of trademarks for the German economy in total as well as for single industries. Moreover, it provides empirical evidence that firms use trademarks to overcome the distance to their customers, differentiate their products against those from competitors, and that product innovations in particular are associated to trademark registrations.

\section{The Impact of Brand Use on Innovation Performance}

The market launch of product innovations is the most visible output of a firm's investment in innovation activities. To achieve this objective most efficiently, firms strengthen their technological capabilities, acquire external knowledge in a number of different ways, and optimize their innovation process. The success of a firm's innovation strategy has two dimensions: First, the ability of a firm to master the research and development process, leading to the market introduction of a product innovation. Second, the ability to turn the market introduction of a product innovation into commercial success. While a firm's technological capabilities are conducive for developing a product innovation, this new product might face a lack of interest among potential customers after its market introduction. The introduction of a product innovation under a brand name might generate interest, add credibility and reputation and has the potential for the firm to better appropriate the returns from its innovations. Chapter 3 investigates the role of brand use for the commercial success of product innovations, using a representative sample of German firms. The results show that firms can improve the odds of commercial success by pursuing a branding strategy. The market introduction of a product innovation is shown to be associated with $35 \%$ larger sales if the firm uses an established brand to introduce the product innovation into the market.

\section{Investments in Brand Equity and Firm Profitability}

A firm has to invest to establish a brand in the marketplace. Whether this investment pays off for an average firm is a priori not clear. Chapter 4 demonstrates empirically that past brand-related investments contribute to current profits. Brandrelated investments are proxied by the flow of trademark registrations over the past thirty years. Based on a representative panel of German firms from 2001 to 2010, the results show an inverse U-shaped profile of brand-related investments. On average, it takes four years until brand-related investments show a positive return, and 
twelve years until their return peaks. Investments older than twenty-three years have no significant impacts anymore.

\section{Intangible Assets and Productivity}

Empirical studies show positive associations between the use of trademarks and firm success (Sandner and Block, 2011; Griffiths et al., 2011; Greenhalgh and Rogers, 2012). Consequently, Corrado et al. (2009) captured brand equity as one central part of a firm's intangible assets. Chapter 5 explores to which extent different kinds of intangible assets are conducive to firm-level productivity. The chapter contributes to the literature by simultaneously comparing productivity effects of innovative capital, human capital, branding capital and organizational capital and testing whether complementarity or substitutability exists between different intangible assets. Using panel data for the period 2006-2010, econometric estimates confirm strong positive productivity effects of human capital and branding capital. Results for innovative capital are found to be mixed. While R\&D has a strong positive impact on productivity, design \& licenses and patents show only weak productivity enhancing effects. The same holds for organizational capital. The results are robust to various parametric (OLS, FE) and non-parametric (Olley and Pakes, Levinsohn and Petrin) productivity estimation methods. The study also provides evidence that innovative capital and branding capital are complements.

\subsection{Thesis Outline}

The thesis consists of four academic papers. Chapter 2 sets the scene by investigating to what extent German firms use trademarks to legally protect their brands and what determines their decision to do so. Chapter 3 analyses the impact of branduse on a firm's innovation performance. Firm's invest huge amounts in marketing activities. Whether brand-related investments pay-off in terms of profits is analysed in Chapter 4. Chapter 5 investigates the role of intangible assets on firm productivity. A firm's brand equity, one of the most important intangible assets, is shown to have a positive impact on productivity. Chapter 6 closes with an overall summary, discussion and general conclusions. 



\section{Chapter 2}

\section{Which Firms Use Trademarks - and Why? Representative Firm-Level Evidence from Germany}

\section{$2.1 \quad$ Introduction}

Brands and trademarks have a ubiquitous presence throughout the economy and in our everyday life. This has its advantages. They enable us to identify and memorise products, to determine their origin, and to distinguish products of different providers from each other. The identifiability of a product is an essential requirement for customers to draw on previous experiences with a product while making purchasing decisions. The experiences with a product, even those of others, may prove useful to assess otherwise unobservable product characteristics. Positive experiences are likely to lead to repeated purchases, while disappointed customers are more likely to avoid the product. This constitutes an incentive for firms to build a reputation to deliver products and services of a reliable quality, leading to the quality guarantee, implicitly indicated by trademarks. In turn, producers are able to differentiate their products against those of competitors and to establish brand reputation, leading, at best, to brand loyalty.

A brand is of economic value only if the respective firm has the right to use this reputational asset exclusively. In Germany, as in most European countries, the protection of marks might be obtained on the basis of use in commerce. Protection is awarded if the mark is used intensively in commerce and a significant proportion of the relevant public has knowledge of the mark. A formal registration does not take place; trademarks acquired by use are therefore not observable by the researcher. There are good reasons for firms not to rely solely on the protection acquired by use and to choose an official registration: A trademark is protected once it is reg- 
istered $;^{2}$ knowledge of the relevant public is not necessary. The scope of protection includes the selected product and service classes and applies to the whole territory of Germany; protection is not limited to the region in which the relevant public has knowledge of the mark. Registration takes place at reasonable cost: the registration fee at the German trade mark office (DPMA) amounts to 290 Euro and at the European Office (OHIM) to 900 Euro, possibly augmented by attorneys fees.

The registration of a brand as a trademark or through a bundle of trademarks protects the reputation of a brand. The registration defines the firm's rights against counterfeiting and fraud. The owner of this right is given a legal monopoly over the protected word, sign, symbol or other graphical representation in connection with the attached commodity. He has the exclusive right to commercially use the protected trademark and is exclusively protected against infringement (Economides, 1998; Baroncelli et al., 2004). The protection from misuse happens not automatically; the trademarking firm has to proactively police for trademark violations and enforce its rights against infringement. Von Graevenitz (2007) emphasizes that trademark owners need the "reputation of being tough on imitators".

Empirical studies show positive associations between the use of registered trademarks and firm success. A trademarking firm exhibits on average a higher productivity (Greenhalgh and Longland, 2005; Greenhalgh and Rogers, 2012; Crass and Peters, 2014, see Chapter 5), is more profitable (Griffiths et al., 2011; Crass et al., 2014, see Chapter 4), yields higher market valuation (Bosworth and Rogers, 2001; Sandner and Block, 2011; Greenhalgh and Rogers, 2012), and has a better propensity to survive in the market (Jensen et al., 2008; Buddelmeyer et al., 2010; Helmers and Rogers, 2010). Schautschick and Greenhalgh (2013) provide a detailed overview. The empirical studies provide evidence of a positive contribution of trademarking to firm performance. This implies that a non-trademarking firm could benefit from adopting a trademark strategy. Hall et al. (2012) expect trademarks to be "the most widely used" intellectual property right that is "available to essentially any firm". Graham et al. (2013) state that "almost every firm, regardless of size, market, or business strategy, has goodwill to protect". From this perspective, perhaps not every firm but the vast majority of firms can be expected to register trademarks. But why does - quite the opposite - a vast majority of firms register no trademarks at all? In Germany, about four out of five firms do not register trademarks and just $18 \%$ of the firms are trademarking firms.

The group of trademarking firms seems to be special - or to be more precise, the group of firms registering trademarks. The empirical literature has stressed that larger firms use trademarks more frequently and that the proportion of trademarking firms is highest for manufacturing and especially for high-tech manufacturing firms (Greenhalgh et al., 2011; Millot, 2011; Crass and Peters, 2014). But are there any

\footnotetext{
${ }^{2}$ The term trademark refers to the legal right that belongs to the wider family of intellectual property rights.
} 
other reasons as to why relatively few firms register trademarks? The purpose of this study is to describe relevant circumstances under which trademarks might be powerful instruments for a firm and to shed more light on firm and product characteristics that influence a firm's decision to trademark.

The empirical analysis relies on 5,335 firm-level observations from the 2011 survey of the Mannheim Innovation Panel (MIP). The 2011 survey provides information on firms trademark activity, their branding policy, as well as their competitive environment. The stratified random sample also allows for extrapolations to the total of German firms with at least five employees in the business sector. The data confirms large heterogeneity by size. While $73.9 \%$ of large firms with 1,000 employees and more rely on trademarks, it turns out that the proportion of small firms with 5 to 49 employees is quite low at about $13.6 \%$. As already mentioned, the extrapolated proportion of trademarking firms amounts to $17.8 \%$.

The existing literature is extended in the following ways: Firstly, using a representative sample of German firms, the study provides extrapolated figures about the use of trademarks for the German business sector in total as well as for single industries. Second, it provides large-scale empirical evidence on the drivers of trademark decisions. Results show that firms use trademarks to overcome the distance to their customers, make product quality more assessable, differentiate their products against a limited (not large) number of competitors, and that especially R\&D activities and product innovations induce the registration of trademarks.

\subsection{The Role of Trademarks}

\subsubsection{The Reputation of Trademarks}

A trademark is a sign which is able to distinguish the firm's product(s) from those of its competitors. It is intended to identify the origin of a product, but the information content of the actual sign is quite limited - unless it is charged with meaning. Economides (1998) highlights that a meaningful and thereby valuable trademark "will be created with its identification with the product." The identification can be accomplished in several ways. Borden (1944) argued that consumers associate the product with a trademark through recommendation, through use, or through advertisement. The association with a trademark makes former experiences with the product recognizable; own experiences, or even those of other people, can be assigned to the trademark to assess a product's quality.

\section{Distance to Customers}

Trademarks are certainly not a recent invention. Moore and Reid (2008) emphasize that trademarks "have existed for as long as it has been possible to trace artefacts 
of human existence." But they underline, that trademarks became "more complex through time". Borden (1944) described the point at which trademarks, which served (just) as a guarantee of origin, reached the next level of complexity and became a valuable asset for a company:

He stresses the relevance of a "close contact" between "the maker and the buyer". Their "close contact", in an environment where everyone knows each other, provides a basis for a (often long-standing) personal relationship. The "maker" is able to build a reputation in the course of the relationship and "the buyer" in turn is enabled to assess the quality of the goods and services. The reputation of the "maker" might not guarantee the best quality of the goods and services for "the buyer" - but it limits the degree of uncertainty about the product. Borden (1944) dated the lost of a "close contact" to the Middle Ages, where goods were traded over long distances. Trademarks took the place of the crucial personal relationship and became more and more "guides of quality to buyers".

The times when people ("the maker and the buyer") knew each other, which Borden (1944) referred to as village economy, are gone; though not completely. Many firms offer their goods and services solely in the immediate vicinity of where the company is located. This is often true in the case of handicraft businesses, law firms, or restaurants. These firms are able to maintain long standing customer relationships even in our highly specialised economy. The personal relationship is here of primary importance and trademarks play only a subordinate role.

Geographical proximity of "the maker and the buyer" might not be the only way to establish a personal relationship. A firm might be able to maintain very close contacts with its customers for example through regular meetings and client visits. The larger the distance that separates a firm from its customers, the larger the costs to overcome the distance. The costs of labour and travel-related expenses limit the number of customers with which a "close contact" is worthwhile. Overall, this leads to the expectation that trademarks are of minor importance for regional providers and firms with comparatively few customers.

\section{Product Quality and the Role of Trademarks}

Consumers do often not possess full knowledge of the quality characteristics of the products and services offered. Imperfectly informed customers are not able to price at the moment of the purchase unobservable quality features. A consumer would, consequently, not pay for unobservable and from her perspective at best uncertain quality features. For the maker of the product, however, these features are costly. It would not be profitable for a firm "to incur higher costs for unobservable quality improvements if these could not be signalled to the prospective buyers to justify a higher sales price" (Baroncelli et al., 2004). Unobservable quality improvements would be crowded out from the market. 
A trademark is an instrument designed to avoid this kind of market failure induced by information asymmetries. Akerlof (1970) refers already to trademarks as "an institution which counteracts the effects of quality uncertainty". A trademarked product is identifiable and recognizable so that customers are able to rely on former consumption experiences. After experiencing a product, they are better able to assess "how functional or effective the product is; how reliable it is; how long it last; how easy it is to use; how it tastes, sounds or smells; and what side effects it may have" (WIPO, 2013, p.81).

The information role of trademarks allows firms to build reputation for reliability and a certain consistent quality (Economides, 1998; Landes and Posner, 1987). The consistent quality is not to be confused with high quality. The reputation of the trademark of McDonalds illustrates the difference. While the worldwide operating fast food restaurants are not known for being gourmet restaurants, the trademark has the reputation to deliver a consistent quality everywhere in the world. A consumer can rely on his former culinary experience. He knows exactly what he will get and how the burger will taste. This leads to the expectation that trademarks are especially useful if the characteristics of a product are not directly observable.

\section{Product Substitutability}

Besides the quality information trademarks convey also an image of the product. Sáiz and Fernández (2009) point out that "the intangible prestige of brands is often much more difficult to imitate than the technological information contained in patents." The more this effect increases brand loyalty, the more effective the product differentiation strategy which is likely to result in a weaker price competition. Especially firms with products that are easily substitutable would benefit from a high degree of product differentiation, since this could lead to a less elastic demand (Bagwell, 2007).

\subsubsection{The Link between Innovation and Trademarks}

New trademarks are correlated with the introduction of new product innovations, what qualifies trademarks as proxies for innovation (Mendonca et al., 2004; Jensen and Webster, 2009). But what causes this correlation?

The first explanation is a timing argument: A new product might come with a new name, perhaps a new logo. As part of the preparations for the market introduction, the new signs are registered as a trademark. The immediate registration is not compelling, but advisable: the desired sign might be in conflict with already registered ones and later changes of the sign can become expensive. The resulting coincidence in time of trademark registration and market introduction qualifies the flow of trademarks (not the trademark stock) as proxy for innovations (Greenhalgh and Rogers, 2012). 
The correlation between trademarks and product innovation may also be explained by the information argument. The introduction of a product innovation is per definition the introduction of a good or service that is "new" for a firm's customers. Potential customers have no experience with the new product from former purchases to judge the product quality. Is the new product sold under a trademark, the reputation of the trademark might balance out a consumer's lack of experience with the new product. In this sense, trademarks have the potential to reduce uncertainty about the quality of product innovations. This might be especially relevant for product innovations why innovative firms pursue more often a trademark strategy.

An alternative explanation for the correlation between trademarks and innovation reverses the direction of causality: The reputation for a brand encourages a firm to improve the quality of its products (Ramello, 2006; Greenhalgh and Rogers, 2012). In this case, the stock of trademarks might serve as a proxy for innovation.

\subsection{Empirical Implementation}

\subsubsection{Data Sets}

Firm-level data is obtained from the 2011 survey of the Mannheim Innovation Panel (MIP) which is a stratified random sample (stratified by sector, size and region) of German firms. The MIP is the German contribution to the European-wide harmonized Community Innovation Surveys (CIS). It is based on the concepts and definitions of the Oslo Manual (2005) for collecting data on innovation processes. It targets legally independent firms with at least five employees. The MIP sample is disproportionally drawn. Higher drawing probabilities are applied to larger size classes, cells from Eastern Germany and cells with a high variation of innovation activities. For a more detailed description of the dataset, the survey, and the methodology in general see Peters and Rammer (2013) as well as Aschhoff et al. (2013) for the 2011 survey.

The MIP, started in 1993, is conducted annually. Though it is designed as a panel, the 2011 survey is the only wave which includes information on the distance between firms and customers, product quality, and product substitutability. The 2011 questionnaires had been returned by nearly 7,000 firms in manufacturing and services, which constituted a $20 \%$ response rate. The firms provide information on their innovation activities and general firm information such as sales, employment, exports, and other major control variables. Surveyed MIP firms have been linked with information on firm's trademark activity at the German Patent and Trademark Office (DPMA) and at the Office of Harmonization for the Internal Market (OHIM). ${ }^{3}$

\footnotetext{
${ }^{3}$ Firm-specific trademark information were collected by matching the name of the firms participating in the innovation survey with the names of applicants at the OHIM and the DPMA using a special software developed at ZEW, and including an extensive manual double-check.
} 


\subsubsection{Trademarking Firms}

There are three options for a firm to obtain trademark protection in Germany through registration: Firms can choose between a registration of a national (German) trademark at the German Patent and Trademark Office (DPMA), the registration of a European Community Trademark at the Office of Harmonization for the Internal Market (OHIM), or the registration of an International Trademark at the Bureau of the World Intellectual Property Organization (WIPO). A trademark registration at all three offices has the same protective effect for Germany; a Community trademark or an International Trademark completely replaces the need for a German Trademark - and vice versa (with respect to the territory of Germany). At all offices, the initial term of trademark protection is 10 years and can be indefinitely renewed for further 10-year periods. International Trademarks are not explicitly considered in the empirical analysis, which should not affect the results: An international registration must be based on a registration of the same mark in one of the member states of the Madrid Agreement for the International Registration of Marks. For the sample of German firms in question, an International Trademark is almost certainly based on a Community Trademark or a (national) German Trademark.

The aim of this paper is to explain the firm's trademarking status, regardless of the trademark office chosen. The binary dependent variable trademarks indicates whether a firm has at least one valid trademark in 2010. A trademark is considered as valid, if it has been registered at either trademark office and if its protection period has not expired. This is the case for $31 \%$ of the firms in the sample (Table 2.2).

The sample is, as already pointed out, disproportionally drawn. Firm responses and information from the trademark register are weighted to represent the total firm population covered by the Mannheim Innovation Panel (MIP). Disproportional sampling by sector, size class and region as well as differences in response rates are taken into account. Table 2.1 provides the extrapolated absolute number and the proportion of trademarking firms by sector and size classes. A total of roughly 48,000 firms with more than five employees in the German business sector have at least one valid trademark in 2010. This corresponds to a proportion of $17.8 \%$ of the total firm population surveyed. Trademarks are used by firms in all sectors. The proportion of trademarking firms differs considerably between the various sectors, ranging from $6 \%$ to $57 \%$; less between manufacturing (20.6\%) and service industries (16.1\%). Sectors with high absolute numbers of trademarking firms are wholesale, IT and telecommunication, corporate services, machinery, consultancy and advertising, and metal. The highest share of trademarking firms can be found in the chemicals and pharmaceutical sector ( $57.1 \%$ of all firms), followed by motor vehicles $(38.4 \%)$, IT and telecommunication $(37.9 \%)$, electronics $(36.2 \%)$, and machinery $(34.8 \%)$. The lowest share of trademarking firms can be seen in transportation and 
postal services $(6 \%)$, water, waste disposal, and recycling $(7.2 \%)$, and food, beverage, and tobacco (10.1\%). The largest proportion of firms using trademarks are research-intensive manufacturing $(38 \%)$. The proportion of trademarking firms is much smaller in knowledge-intensive services (19.4\%), other manufacturing (15.7\%), and other services (13.6\%).

The extrapolated figures also suggest that there is a link between firm size (measured by the number of employees in 2010) and a firm's tendency to trademark. The larger a firm the more likely its tendency to register trademarks. A break down by size classes illustrates this relationship: The proportion of trademarking firms is quite low for small firms (less than 50 employees) making up 13.6\% of the total figure. The proportion rises already to $38.8 \%$ for medium-sized firms (50-249 employees) and to $58.8 \%$ for large firms (250-999 employees). The proportion of trademarking firms increases up to $73.9 \%$ for very large firms (1000 and more employees). 
Table 2.1: Absolute Number and Proportion of Trademarking Firms in Germany

\begin{tabular}{|c|c|c|c|}
\hline Sector & WZ 2008 & $\begin{array}{l}\text { Trademarking } \\
\text { absolute }\end{array}$ & $\begin{array}{r}\text { Firms } \\
\text { in \% }\end{array}$ \\
\hline Food/Beverage/Tobacco & $10-12$ & 1,793 & 10.1 \\
\hline Textile/Clothes/Leather & $13-15$ & 767 & 32.0 \\
\hline Wood/Paper & $16-17$ & 644 & 13.6 \\
\hline Chemicals/Pharmaceuticals & $20-21$ & 1,368 & 57.1 \\
\hline Rubber-/Plastics products & 22 & 1,475 & 30.3 \\
\hline Glass/Clay/Stone & 23 & 869 & 24.2 \\
\hline Metal & $24-25$ & 3,250 & 15.6 \\
\hline Electronics & $26-27$ & 2,750 & 36.2 \\
\hline Machinery & 28 & 3,562 & 34.8 \\
\hline Motor vehicles & $29-30$ & 855 & 38.4 \\
\hline Furnit./Toys/Medic. instr./Repair & $31-33$ & 2,393 & 16.6 \\
\hline Energy/Mining/Petroleum & $5-9,19,35$ & 607 & 22.6 \\
\hline Water/Waste disposal/Recycling & $36-39$ & 322 & 7.2 \\
\hline Wholesale & 46 & 7,483 & 19.6 \\
\hline Transportation/Postal services & $49-53,79$ & 1,865 & 6.0 \\
\hline Media services & $18,58-60$ & 2,191 & 26.5 \\
\hline IT/Telecommunication & $61-63$ & 4,996 & 37.9 \\
\hline Financial services & $64-66$ & 1,432 & 20.7 \\
\hline Technical/R\&D services & $71-72$ & 2,205 & 13.6 \\
\hline Consultancy/Advertising & $69,70.2,73$ & 3,470 & 11.1 \\
\hline Corporate services & $74,78,80-82$ & 3,663 & 14.1 \\
\hline Research-intensive manufacturing & $20-21,26-30$ & 8,535 & 38.0 \\
\hline Other manufacturing & $5-19,22-25,31-39$ & 12,512 & 15.7 \\
\hline Knowledge-intensive services & $58-66,69,70.2,73$ & 13,902 & 19.4 \\
\hline Other services & $46,49-53,74,78-82$ & 13,011 & 13.6 \\
\hline \multicolumn{4}{|l|}{ Size Class (\# employees) } \\
\hline $5-49$ & & 31,247 & 13.6 \\
\hline $50-249$ & & 12,272 & 38.8 \\
\hline 250-999 & & 3,457 & 58.8 \\
\hline 1000 and more & & 984 & 73.9 \\
\hline Total & & 47,960 & 17.8 \\
\hline
\end{tabular}

Notes: Firms in Germany having at least 5 employees in German Classification of Economic Activities, 2008 edition (WZ 2008) 5-39, 46, 49-53, 58-66, 69-74 (not 70.1), 78-82. All figures are extrapolated to the total firm population in Germany.

Source: ZEW: Mannheim Innovation Panel, survey 2011. 


\subsubsection{Explanatory Variables}

Based on the expectations developed above, four broad categories of explanatory variables are of special interest in the empirical analyses: distance to customers, product quality, product substitutability, and a firm's innovation activity. They will be explained in the following subsections together with basic firm characteristics which are used as control variables in the regression. Table 2.2 provides the sample mean and standard errors for the full sample in Column (1) and for the subsample of trademarking firms in Column (2). The difference between trademarking and non-trademarking firms shows Column (3). More detailed descriptive statistics are provided in Table 3.8 in the Appendix.

Table 2.2: Descriptive Statistics of Main Variables (not weighted)

\begin{tabular}{|c|c|c|c|c|c|c|}
\hline & \multicolumn{2}{|c|}{$\begin{array}{l}(1) \\
\text { Full Sample }\end{array}$} & \multicolumn{2}{|c|}{$\begin{array}{c}(2) \\
\text { TM-Firms }\end{array}$} & \multicolumn{2}{|c|}{$\begin{array}{c}(3) \\
\text { Difference }\end{array}$} \\
\hline & Mean & SE & Mean & $\mathrm{SE}$ & Diff & SE \\
\hline $\begin{array}{l}\text { Trademark Activity } \\
\text { Trademarks (D) }\end{array}$ & 0.31 & $(0.01)$ & 1.00 & $(0.01)$ & 1.00 & $(0.00)$ \\
\hline $\begin{array}{l}\text { Personal Distance } \\
\text { Few Customers (D) } \\
\text { Many Customers (D) } \\
\end{array}$ & $\begin{array}{l}0.15 \\
0.45 \\
\end{array}$ & $\begin{array}{l}(0.00) \\
(0.01) \\
\end{array}$ & $\begin{array}{l}0.10 \\
0.51 \\
\end{array}$ & $\begin{array}{l}(0.00) \\
(0.01) \\
\end{array}$ & $\begin{array}{r}-0.07^{* * *} \\
0.09^{* * *} \\
\end{array}$ & $\begin{array}{l}(0.01) \\
(0.01) \\
\end{array}$ \\
\hline $\begin{array}{l}\text { Geographical Distance } \\
\text { Regional Market (D) } \\
\text { National Market (D) } \\
\text { International Market (D) }\end{array}$ & $\begin{array}{l}0.63 \\
0.71 \\
0.47\end{array}$ & $\begin{array}{l}(0.01) \\
(0.01) \\
(0.01)\end{array}$ & $\begin{array}{l}0.52 \\
0.88 \\
0.71\end{array}$ & $\begin{array}{l}(0.01) \\
(0.01) \\
(0.01)\end{array}$ & $\begin{array}{r}-0.16^{* * *} \\
0.24^{* * *} \\
0.35^{* * *}\end{array}$ & $\begin{array}{l}(0.01) \\
(0.01) \\
(0.01)\end{array}$ \\
\hline $\begin{array}{l}\text { Product Quality } \\
\text { Quality Assessable (D) }\end{array}$ & 0.22 & $(0.01)$ & 0.21 & $(0.01)$ & -0.02 & $(0.01)$ \\
\hline $\begin{array}{l}\text { Substitutability } \\
\text { Products Substitutable (D) } \\
\text { Few Competitors (D) } \\
\text { Many Competitors (D) }\end{array}$ & $\begin{array}{l}0.21 \\
0.42 \\
0.19\end{array}$ & $\begin{array}{l}(0.01) \\
(0.01) \\
(0.01)\end{array}$ & $\begin{array}{l}0.16 \\
0.47 \\
0.12\end{array}$ & $\begin{array}{l}(0.01) \\
(0.01) \\
(0.01)\end{array}$ & $\begin{array}{r}-0.07^{* * *} \\
0.07^{* * *} \\
-0.10^{* * *}\end{array}$ & $\begin{array}{l}(0.01) \\
(0.01) \\
(0.01)\end{array}$ \\
\hline $\begin{array}{l}\text { Innovation } \\
\text { Continuous R\&D (D) } \\
\text { EPO Patent (D) } \\
\text { Process Innovation (D) } \\
\text { Product Innovation (D) }\end{array}$ & $\begin{array}{l}0.22 \\
0.12 \\
0.32 \\
0.44\end{array}$ & $\begin{array}{l}(0.01) \\
(0.00) \\
(0.01) \\
(0.01)\end{array}$ & $\begin{array}{l}0.40 \\
0.30 \\
0.44 \\
0.65\end{array}$ & $\begin{array}{l}(0.01) \\
(0.00) \\
(0.01) \\
(0.01)\end{array}$ & $\begin{array}{l}0.27^{* * *} \\
0.26^{* * *} \\
0.16^{* * *} \\
0.30^{* * *}\end{array}$ & $\begin{array}{l}(0.01) \\
=(0.01) \\
(0.01) \\
(0.01)\end{array}$ \\
\hline $\begin{array}{l}\text { Basic Characteristics } \\
\text { Firm Size (\# of employees) } \\
\text { Group (D) } \\
\text { East Germany (D) } \\
\text { Firm Age (in years) }\end{array}$ & $\begin{array}{r}203.15 \\
0.29 \\
0.32 \\
32.96\end{array}$ & $\begin{array}{r}(21.07) \\
(0.01) \\
(0.01) \\
(0.50)\end{array}$ & $\begin{array}{r}457.59 \\
0.44 \\
0.23 \\
37.50\end{array}$ & $\begin{array}{r}(21.07) \\
(0.01) \\
(0.01) \\
(0.50)\end{array}$ & $\begin{array}{r}370.40^{* * *} \\
0.22^{* * *} \\
-0.13^{* * *} \\
6.61^{* * *}\end{array}$ & $\begin{array}{l}(29.27) \\
(0.01) \\
=(0.01) \\
(1.05)\end{array}$ \\
\hline
\end{tabular}

The first column provides mean and standard error of the main variables for the full sample, the second column for the subsample of trademarking firms, and the third column provides the difference between trademarking and non-trademarking firms. D indicates a dummy variable.

Source: ZEW: Mannheim Innovation Panel, survey 2011.

\section{Distance Between Firm and Customer}

The distance between the firm and its customers is captured through two different dimensions: the geographical distance and the personal distance.

The geographical distance is measured through the geographic markets in which a firm is active. Three dummy variables account for a firm's activity in the local 
market (the firm sells goods or services within a radius of $50 \mathrm{~km}$ ), the national market (Germany), and/or the international market. A firm is able to serve all or only some geographical markets. The local market allows, from the geographical perspective, the closest contact between a firm and its customers and is served by $63 \%$ of the sample firms. Corollary, this means, that the local market is not relevant for the remaining $37 \%$ and that those firms have to deal more often with geographical distance. The same is true for $71 \%$ that serve the national market, and nearly half of the firms $(47 \%)$ that serve the international market. Firms could use trademarks to deal with geographical distance. Table 2.2 supports this view: trademarking firms are more frequently active at the national or international level and less at the regional market.

The second distance dimension, the personal distance, captures the ability of a firm to build a personal relationship between its staff members and its customers. It is reasonable to assume that the more customers a firm has, the less able it is to establish a close relationship with all of its customers. The number of customers would be a good measure of the personal distance but is, unfortunately, not available from the survey and often unknown to the firm as well. The survey, instead, provides information on the share of turnover with the three most important customers. This measure is able to proxy the number of customers quite well: A firm that reports a share of turnover of 100 percent for its three most important customers, has not more than three customers. The lower the reported share, the larger in general the number of customers. Based on this survey information, the two binary variables few customers and many customers account for personal distance. A close contact seems to be reachable for $15 \%$ of the sample firms with only few customers, while $45 \%$ are characterized as having many customers, associated with larger personal distance. Again, firms might deal with personal distance by using trademarks. The descriptive statistics (Table 2.2) are in line with this argument since the proportion of trademarking firms is larger with many customers and smaller with few customers.

\section{Substitutability of Products and Services}

Firms might be more likely to pursue a product differentiation strategy if operating in product markets in which product-substitutability is high. Whether a firm operates in a market in which products are substitutable is direct information from the questionnaire and based on the assessment of the firms. About $21 \%$ of the sample firms state that they operate in a market where products are substitutable, while this applies only for $16 \%$ of the trademarking firms.

The number of (main) competitors serves additionally as a measure of product substitutability and is again direct information from the survey. A firm with no or just few competitors sells goods and services which are, due to the lack of alternative suppliers, less easily substituted. The larger the number of competitors, the higher 
the number of potential providers and consequently the degree of substitutability. A small number of competitors (up to five) is considered as few competitors and a large number (more than 50 competitors) as many competitors. Any number of competitors in between serves as the reference category. It turns out from the descriptive statistics that trademarking firms are less often faced by many competitors ( $12 \%$ in contrast to $22 \%$ of non-trademarking firms) and operate more often in a competition environment with few competitors (47\% in contrast to $40 \%$ ).

\section{Product Quality}

An important aspect of product quality concerns the assessability of quality by customers prior to the purchase. The firms were asked to assess on a four-point Likert scale (ranging from "applies not" to "applies fully") whether it is difficult for customers to assess the quality in a firm's product market. The binary variable quality assessable equals one, if customers have no difficulties to assess the product quality. Overall, that is the case for $22 \%$ of the firms. The proportion of suppliers with assessable quality is not smaller for trademarking firms (see Table 2.2).

\section{Innovative Activity of Firms}

Innovative firms are supposed to benefit particularly from the use of trademarks. A firm's technological capability and its innovative capability are used to identify innovative firms. Two dummy variables serve as indicators for a firm's technological capability: continuous internal R\&D activities and at least one patent application at the European Patent Office (EPO). Continuous REDD is again direct information from the survey. Descriptive statistics reveal large differences between trademarking and non-trademarking firms: $40 \%$ of the trademarking firms conduct R\&D continuously but just $13 \%$ of non-trademarking firms. The results for an EPO patent are similar: $30 \%$ of the trademarking and just $4 \%$ of the non-trademarking firms have a patent application at the EPO. Research oriented firms seem to be also trademarkoriented ones.

The innovative capability of a firm is captured by the current level of innovative activity, proxied by a set of dummy variables that indicates process innovation and process innovation during the period 2008 to 2010. Again, trademarking firms are more often innovative: $44 \%$ introduced a process innovation (in contrast to $28 \%$ of non-trademarking firms) and $65 \%$ a product innovation (in contrast to $35 \%$ of non-trademarking firms). The current level of innovation seems to proxy the general innovativeness of a firm quite well, since innovation is shown to be persistent within firms (Peters, 2009). 


\section{Basic Firm Characteristics}

The group of basic firm characteristics includes besides firm size also firm age (measured in years), the type of ownership, the region of a firm's location, and its sector affiliation. The type of ownership distinguishes between unaffiliated firms (reference group) and those that belong to a group. The region distinguishes between firms located in West- (reference group) and East Germany and the sector affiliation between 21 aggregated sector groupings.

\section{$2.4 \quad$ Empirical Findings}

\subsubsection{The Propensity to Trademark}

The dependent variable indicates whether a firm uses trademarks. Due to the binary character of the dependent variable, I use a probit model for the econometric analysis. The cross-sectional data allows no interpretation of the results as causal effects; the results should thus be taken as associations rather than as causal relationships. The main estimation results of gradually enriched probit models are presented in Table 2.3. ${ }^{4}$ Each of the four columns contain two sub-columns, where the first provides the coefficients and standard errors from the regression and the second sub-column provides the more informative average marginal effects. Column (1) presents the estimates for a specification which only accounts for basic firm characteristics. The specification is gradually enriched by including components of personal and geographical distance, product quality, and product substitutability in Column (2). Alternatively, model (3) accounts for basic firm characteristics and innovation activity. The complete set of explanatory variables is used for estimation in Column (4).

A randomly drawn sample firm uses at least one trademark with a propensity of $31.3 \%$. The regression results provide some more differentiated insights into the propensity to trademark in Column (1), solely based on basic firm characteristics. Firms are characterized by size, group status, location, firm age, and sector affiliation. As the results show, the size of a firm has a highly significant impact: the larger a firm, the higher the propensity to trademark. A one unit increase of firm size (the logarithm of the number of employees) increases the probability of using trademarks by 9.1 percentage points. The estimated marginal effect is lowered to 6.2 percentage points, after controlling for all additional variables in Column (4). This indicates that firm size is positively correlated to these variables and captures them partly.

The single number of 6.2 percentage points represents the average marginal effect of firm size - but the effect might vary across the range from small to large firms.

\footnotetext{
${ }^{4}$ The results of a weighted estimation are provided in Table 2.8 in the Appendix. The results differ only slightly.
} 
Table 2.3: Firm Characteristics and the Propensity to Trademark

\begin{tabular}{|c|c|c|c|c|c|c|c|c|}
\hline & \multicolumn{2}{|c|}{$\begin{array}{c}(1) \\
\text { Trademarks (D) }\end{array}$} & \multicolumn{2}{|c|}{$\begin{array}{c}(2) \\
\text { Trademarks (D) }\end{array}$} & \multicolumn{2}{|c|}{$\begin{array}{c}(3) \\
\text { Trademarks (D) }\end{array}$} & \multicolumn{2}{|c|}{$\begin{array}{c}(4) \\
\text { Trademarks (D) }\end{array}$} \\
\hline & $\beta / \mathrm{SE}$ & $\mathrm{ME}$ & $\beta / \mathrm{SE}$ & $\mathrm{ME}$ & $\beta / \mathrm{SE}$ & $\mathrm{ME}$ & $\beta / \mathrm{SE}$ & $\mathrm{ME}$ \\
\hline \multicolumn{9}{|l|}{ Basic Characteristics } \\
\hline Firm Size & $\begin{array}{l}0.316^{* * *} \\
(0.016)\end{array}$ & $0.091^{* * *}$ & $\begin{array}{l}0.282^{* * *} \\
(0.016)\end{array}$ & $0.076^{* * *}$ & $\begin{array}{l}0.263^{* * *} \\
(0.016)\end{array}$ & $0.070^{* * *}$ & $\begin{array}{l}0.243^{* * *} \\
(0.017)\end{array}$ & $0.062^{* * *}$ \\
\hline Group & $\begin{array}{l}0.120^{* *} \\
(0.048)\end{array}$ & $0.035^{* *}$ & $\begin{array}{c}0.074 \\
(0.049)\end{array}$ & 0.020 & $\begin{array}{c}0.065 \\
(0.050)\end{array}$ & 0.018 & $\begin{array}{c}0.036 \\
(0.051)\end{array}$ & 0.009 \\
\hline East Germany & $\begin{array}{l}-0.248^{* * *} \\
(0.044)\end{array}$ & $-0.070^{* * *}$ & $\begin{array}{l}-0.195^{* * *} \\
(0.046)\end{array}$ & $-0.053^{* * *}$ & $\begin{array}{l}-0.223^{* * *} \\
(0.045)\end{array}$ & $-0.059 * * *$ & $\begin{array}{l}-0.180^{* * *} \\
(0.047)\end{array}$ & $-0.046^{* * *}$ \\
\hline Firm Age & $\begin{array}{l}-0.001 \\
(0.024)\end{array}$ & -0.000 & $\begin{array}{c}0.009 \\
(0.025)\end{array}$ & 0.002 & $\begin{array}{c}0.013 \\
(0.025)\end{array}$ & 0.004 & $\begin{array}{c}0.013 \\
(0.026)\end{array}$ & 0.003 \\
\hline \multicolumn{9}{|l|}{ Personal Distance } \\
\hline Few Customers & & & $\begin{array}{l}-0.153^{* *} \\
(0.065)\end{array}$ & $-0.040^{* *}$ & & & $\begin{array}{l}-0.159^{* *} \\
(0.066)\end{array}$ & $-0.039^{* *}$ \\
\hline Many Customers & & & $\begin{array}{l}0.147^{* * * *} \\
(0.045)\end{array}$ & $0.040 * * *$ & & & $\begin{array}{l}0.146^{* * *} \\
(0.046)\end{array}$ & $0.038^{* * *}$ \\
\hline \multicolumn{9}{|l|}{ Geographical Distance } \\
\hline Regional Market & & & $\begin{array}{l}-0.204^{* * *} \\
(0.043)\end{array}$ & $-0.056^{* * *}$ & & & $\begin{array}{l}-0.177^{* * *} \\
(0.044)\end{array}$ & $-0.046^{* * *}$ \\
\hline National Market & & & $\begin{array}{l}0.418^{* * *} \\
(0.059)\end{array}$ & $0.111^{* * *}$ & & & $\begin{array}{l}0.401^{* * *} \\
(0.059)\end{array}$ & $0.101^{* * *}$ \\
\hline International Market & & & $\begin{array}{l}0.450^{* * * *} \\
(0.048)\end{array}$ & $0.127^{* * *}$ & & & $\begin{array}{l}0.353^{* * *} \\
(0.049)\end{array}$ & $0.094^{* * *}$ \\
\hline \multicolumn{9}{|l|}{ Product Quality } \\
\hline Quality Assessable & & & $\begin{array}{l}-0.139 * * * \\
(0.050)\end{array}$ & $-0.037^{* * *}$ & & & $\begin{array}{l}-0.138^{* * *} \\
(0.051)\end{array}$ & $-0.035^{* * *}$ \\
\hline \multicolumn{9}{|l|}{ Substitutability } \\
\hline Products Substitutable & & & $\begin{array}{c}-0.080 \\
(0.053)\end{array}$ & -0.022 & & & $\begin{array}{l}-0.036 \\
(0.054)\end{array}$ & -0.009 \\
\hline Few Competitors & & & $\begin{array}{l}0.140^{* * *} \\
(0.045)\end{array}$ & $0.039 * * *$ & & & $\begin{array}{l}0.093^{* *} \\
(0.046)\end{array}$ & $0.024^{* *}$ \\
\hline Many Competitors & & & $\begin{array}{l}-0.206^{* * *} \\
(0.060)\end{array}$ & $-0.053^{* * *}$ & & & $\begin{array}{l}-0.173^{* * *} \\
(0.060)\end{array}$ & $-0.043^{* * *}$ \\
\hline \multicolumn{9}{|l|}{ Innovator } \\
\hline Continuous R\&D & & & & & $\begin{array}{l}0.242^{* * *} \\
(0.061)\end{array}$ & $0.068^{* * *}$ & $\begin{array}{l}0.208^{* * *} \\
(0.062)\end{array}$ & $0.056^{* * *}$ \\
\hline EPO Patent & & & & & $\begin{array}{l}0.866^{* * *} \\
(0.067)\end{array}$ & $0.275^{* * *}$ & $\begin{array}{l}0.800^{* * * *} \\
(0.069)\end{array}$ & $0.240^{* * *}$ \\
\hline Process Innovation & & & & & $\begin{array}{c}-0.019 \\
(0.046)\end{array}$ & -0.005 & $\begin{array}{l}-0.042 \\
(0.047)\end{array}$ & -0.011 \\
\hline Product Innovation & & & & & $\begin{array}{l}0.292^{* * *} \\
(0.051)\end{array}$ & $0.081^{* * *}$ & $\begin{array}{l}0.203^{* * *} \\
(0.052)\end{array}$ & $0.053^{* * *}$ \\
\hline W_Industry & 0.000 & & 0.000 & & 0.000 & & 0.000 & \\
\hline McFadden's R2 & 0.181 & & 0.228 & & 0.231 & & 0.263 & \\
\hline McFadden's Adj R2 & 0.172 & & 0.215 & & 0.219 & & 0.247 & \\
\hline Correctly Classified (\%) & 71.230 & & 73.170 & & 75.092 & & 75.275 & \\
\hline Correctly Classified $1(\%)$ & 72.063 & & 76.096 & & 70.836 & & 74.342 & \\
\hline Correctly Classified $0(\%)$ & 70.850 & & 71.836 & & 77.032 & & 75.699 & \\
\hline Observations & 5464 & & 5464 & & 5464 & & 5464 & \\
\hline
\end{tabular}

Source: ZEW: Mannheim Innovation Panel, survey 2011.

Williams (2012) recommends to choose ranges of values for one or more independent variables (in this case firm size) and calculate marginal effects for this range of representative values. Figure 2.1 provides average adjusted predictions (AAPs) and average marginal effects (AMEs) for a plausible range of firm size. The AAPs in Figure 2.1a illustrate the relevance of firm size after controlling for all other variables: a firm with 10 employees, which is at the border of being classified from very small to small (in logarithm at 2.3, the first dotted line), has a $22.3 \%$ predicted probability 
Figure 2.1: Firm Size: a) Average Adjusted Predictions (AAPs), b) Average Marginal Effects (AMEs)

(a) AAPs and 95\% confidence intervals

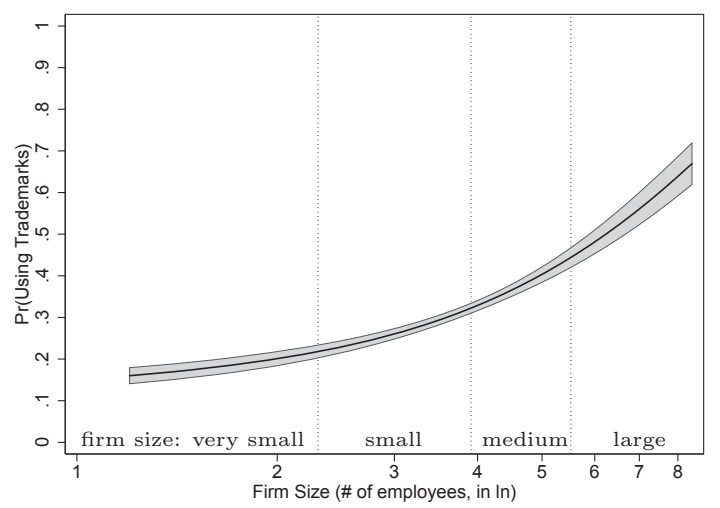

(b) AME and 95\% confidence intervals

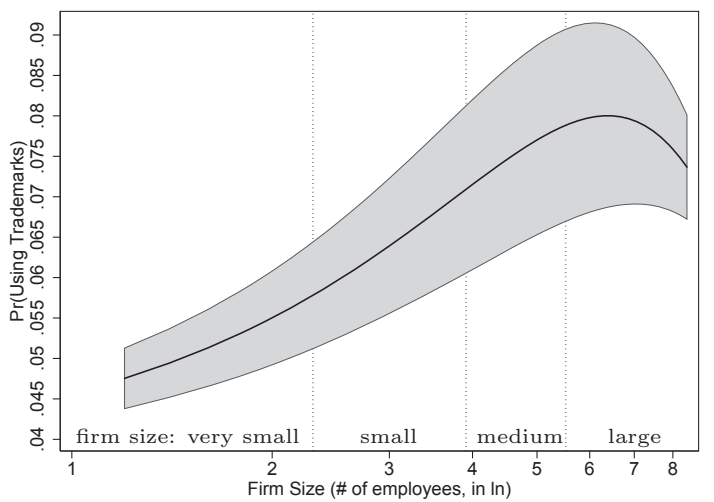

of using trademarks. A firm with 50 employees, which is on the border of being medium sized, has a $32.4 \%$ predicted probability and one with 250 employees on the border of being large, has a predicted probability of $44.1 \%$ to use trademarks. The average marginal effects (AMEs) are presented in Figure 2.1b for exactly the same range of firm size. The graph shows that increases in firm size produce for firms up to 600 employees (about 6.4 in logarithm) an increase in firm size increases the marginal effect of trademarking. This is the case for slightly less than $95 \%$ of all firms in the sample. An additional increase in firm size after 600 employees produces smaller but still positive increases in the likelihood to register trademarks.

A firm is, beside its size, also characterized by its group status, its location in East or West Germany, and its sector affiliation. After controlling for all additional variables in Column (4), the propensity to register trademarks is reduced by 4.6 percentage points for a firm located in East Germany. Whether a firm is part of a group and the age of a firm has no significant effect.

\subsubsection{Distance, product quality and substitutability matters}

Results for the first set of additional firm characteristics is given in Column (2). The results provide evidence that both dimensions of distance between a firm and its customers are significantly correlated to the use of trademarks: Trademarks are on average 4.0 percentage points less likely used in the case of low personal distance (few customers), while large personal distance (many customers) induce a 4.0 percentage points increase in the propensity to trademark. Furthermore, firms propensity to use trademarks is about 5.6 percentage points smaller in the case of a low geographical distance (regional market) and significantly higher in the case of a large distance; 11.1 percentage points larger for firms that serve the national market and 12.7 percentage points for those that serve the international market. 
The marginal effects are just slightly smaller after controlling for the full set of variables in Column (4).

Figure 2.2: Distance to Customers matters, Adjusted Predictions at Representative Values (APRs)

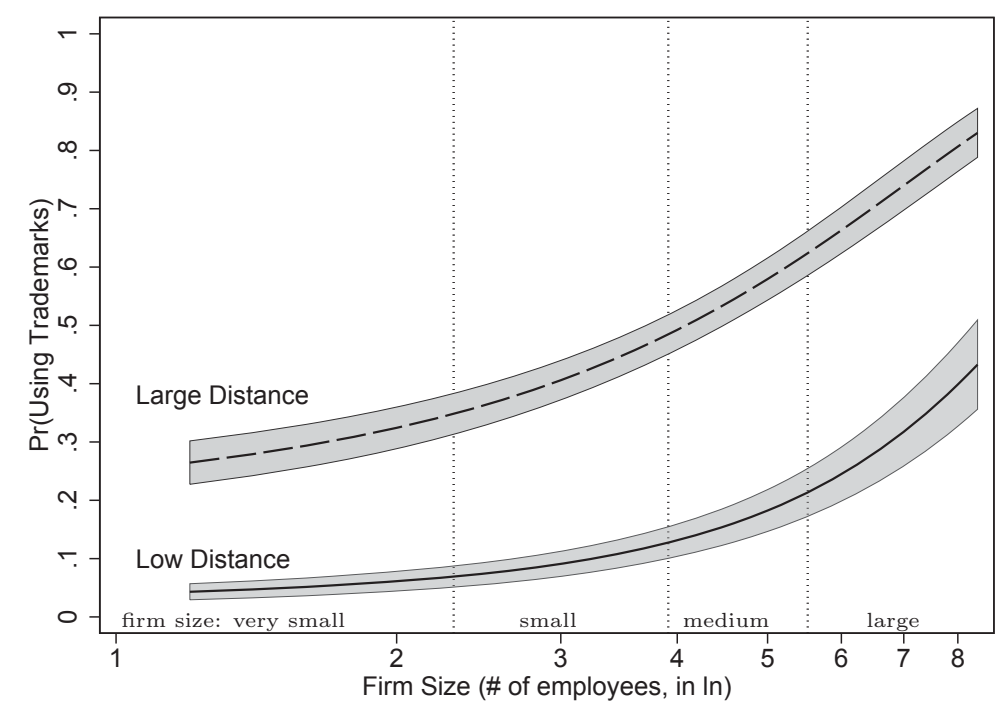

Notes: Large distance is defined as serving the national and international market as well as having many customers. Low distance firms serve just the regional market and have few customers.

To illustrate the relevance of distance in more detail, Figure 2.2 shows adjusted predictions for the same range of firm size as above, but distinguished by distance to customers. Low distance is defined as having a limited personal distance (few customers) and as having a limited geographical distance (being active just at the local market). Large distance firms are those with many customers, which are also active at the national and international market. Figure 2.2 tellingly reveals along the firm size distribution that the probability of trademarking is significantly larger for firms with a large distance, compared to those with a low distance to their customers - even after controlling for all other variables. A firm with large distance and 250 employees (in logarithm at 5.5, the third dotted line) has a three times higher predicted probability of trademarking (63\% instead of $19.4 \%$ ) than an equally sized firm with low distance to its customers. A small firm with 10 employees (in logarithm at 2.3, the first dotted line) and a large distance has actually a six times higher predicted propensity to trademark.

This implies that trademarks are frequently used as an instrument to overcome distance, which is otherwise preventing a close relationship to customers. A low distance on the other hand limits the need for trademarks, since it enables firms to establish a close relationship with its customers.

Trademarks are also less often needed, if the quality of a firm's products is easily to assess: Firms in a product market in which products are of assessable quality have a 3.4 percentage points lower probability of using trademarks. This confirms that 
a trademark is a useful instrument to signal those product quality features that are otherwise not obvious.

Figure 2.3: Substitutability matters, Average Adjusted Predictions (AAPs)

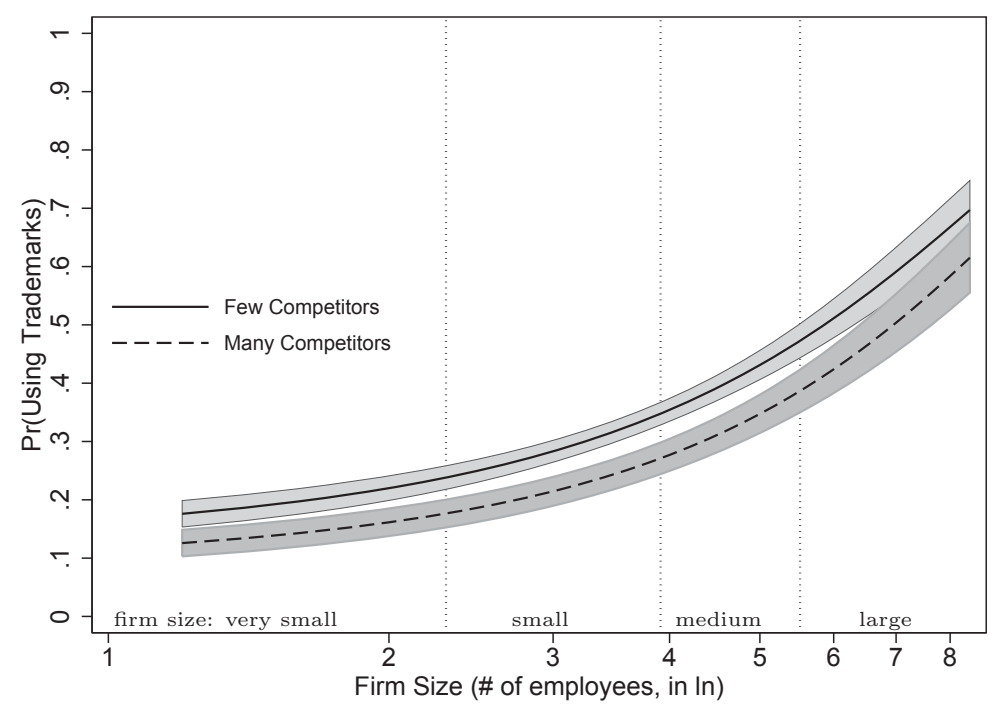

The degree of competition is used to proxy product substitutability. A low number of competitors (few competitors) indicates limited competition, which is correlated with a 3.9 percentage points larger probability to use trademarks. A large number of competitors (many competitors) is considered as strong competition, which is correlated with a 5.3 percentage points lower propensity to trademark. This indicates that trademarks are used to differentiate a firms' product especially in the case of a small number of main competitors. Figure 2.3 compares adjusted predictions for firms with few and many competitors. The largest differences arise for small to medium sized firms with about 50 employees. The overlapping areas of the confidence intervals reveal that the difference is not significant for large firms.

The results can also be interpreted as indication for the competition-reducing effect of brands. The presence of strong brands might establish barriers to entry for potential competitors. Market entry is prevented because of the high fixed costs for a firm that enters the market and has to establish competitive brands.

\subsubsection{Innovation matters}

Innovative firms have a larger probability of using trademarks. Firm's conducting continuous $R E B$ have a 6.8 percentage points higher, and those with a patent application at the European Patent Office (EPO) have on average a 27.4 percentage points higher propensity to trademark. Both indicators capture a firm's technological capability and point to research intensive firms. The innovative capability captures the ability of a firm to introduce new products and processes into the market. Firms with product innovations have a 8.1 percentage points larger probability 
of using trademarks, while process innovations have no significant influence.

The highly significant correlation of a firm's innovation activities and its use of trademarks confirms related studies (Mendonca et al., 2004; Greenhalgh and Rogers, 2012). Whether innovation activities lead to trademark registrations or the reverse, a firm's brands lead to innovation activities is not clear.

Figure 2.4: Innovation matters, Average Adjusted Predictions (AAPs)

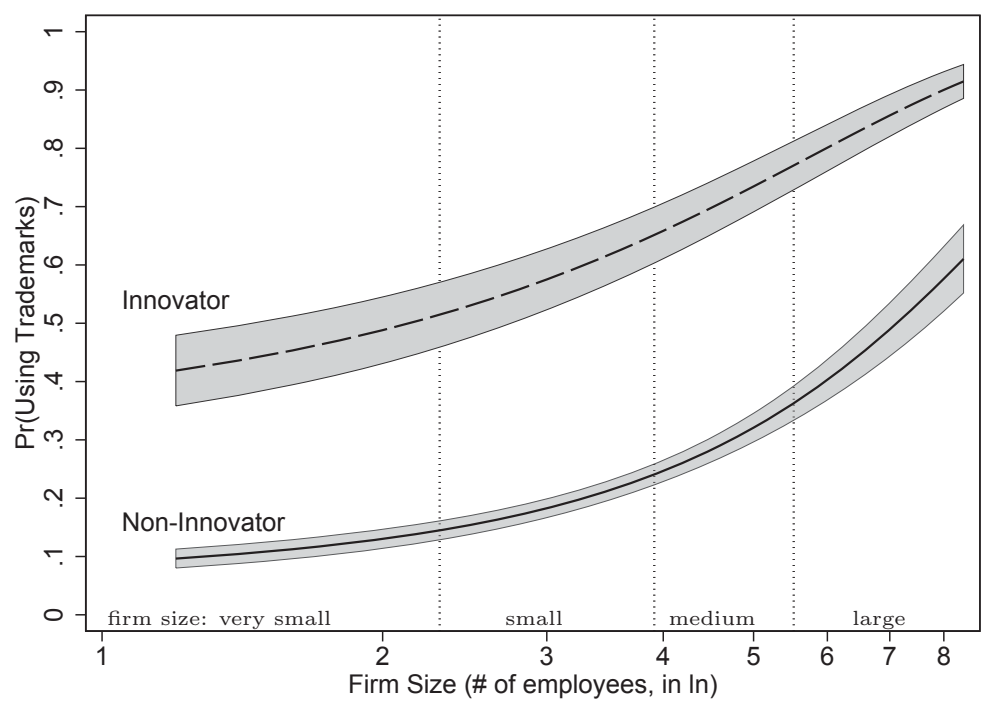

Notes: An innovator is defined as follows: he conducts R\&D continuously, has an EPO patent application, and introduced a product innovation. The opposite is true for the definition of non-innovators.

Adjusted predictions are also chosen to illustrate the difference between innovative and non-innovative firms in Figure 2.4. Innovative firms are defined as firms that undertake R\&D continuously, having a patent application at the EPO, and having introduced a product innovation. Non-innovative firms conduct no R\&D, and have neither a patent registered nor a product innovation introduced. The introduction of process innovations has no significant effect and is therefore not taken into account. The probability of using trademarks differs significantly for the whole range of size classes. An innovative firm with 250 employees (on the border of being between medium and large sized) is more than twice as likely to trademark. After controlling for all other variables, the propensity to trademark is $77.0 \%$ for an innovative firm, compared to $36.4 \%$ for a non-innovative firm. The probability of trademarking of a small innovative firm with 10 employees (in logarithm at 2.3, the first dotted line) is more than three times larger (51.5\% instead of $14.6 \%)$, compared to a non-innovative firm of the same size. 


\subsection{Conclusion}

This paper provides empirical evidence of the proportion of firms that have registered trademarks in 2010 and analyses the role of several firm characteristics that are related to a firm's decision to register trademarks. The empirical analysis relies on a large sample of about 5,400 German firms from many different industries in the business sector. The extrapolated proportion of $18 \%$ of firms with at least one registered and still valid trademark is representative for all firms with more than five employees in the corresponding sectors. While firms in all sectors register trademarks, the differences in the proportions between the sectors are striking. The tendency to register trademarks is particularly high with $38 \%$ for firms in the research-intensive manufacturing sector. The proportion of trademarking firms is considerably lower in knowledge-intensive service sectors $(19.4 \%)$, followed by firms in other manufacturing (15.7\%) and other services (13.6\%). With $57.1 \%$ chemicals and pharmaceuticals firms show the largest proportion of trademarking firms, followed by firms in the motor vehicles sectors with $38.4 \%$. The latter is of comparable size with the proportion of $37.9 \%$ of trademarking firms in the IT and telecommunication sector. Another important aspect for the propensity to trademark is the size of a firm. The larger the firm the larger the probability to register trademarks: among small firms (5-49 employees) the proportion of trademarking firms is comparatively low with $13.6 \%$, while a high proportion of $73.9 \%$ of large firms (with 1,000 or more employees) have registered trademarks.

The empirical analysis investigates to what extent firm and product characteristics matter for the firms decision to use trademarks. The results cannot be taken as indicating causality because of potential endogeneity. But the results provide evidence that the decision of a firm to register trademarks is related to several firm characteristics: the distance between a firm and its customers, the assessability of product quality, the degree of substitutability, and innovative activities of a firm.

Firms with a low level of personal as well as geographical distance use trademarks less often, while firms with larger distances use trademarks more frequently. This result suggests that trademarks are an appropriate instrument to overcome distance and are not needed in circumstances under which a firm and its customers are able to maintain a close relationship. The results of the preferred specification indicates that a medium sized firm with 250 employees has a three times larger predicted probability to register trademarks, if the firm is having a large distance to its customers. The quality features of products offered are sometimes obvious, but more often not straightforward assessable at the time of the purchase. The results show that firms with products, whose quality is difficult to assess, use significantly more often trademarks. This might be interpreted as meaning that trademarks can help to solve the problem of asymmetric information: The reputation of a trademark helps to assess those products. Previous experiences with the product or even with 
similar products of the same brand, can be transferred to the current purchase decision. The results further indicate that trademarks are also more frequently used, if a firm's products are characterized by a limited (but not strong) substitutability. Pursuing a trademark strategy seems to be more promising, if a firm has to distinguish its products against few competitors. In the case of many competitors and thus easy substitutability, trademarks are significantly less used. Another important finding is that a firm that conducts continuous $R \& D$, is engaged in patenting and the introduction of innovative products, has a significantly higher propensity to register trademarks. This confirms that product innovations and the registration of trademarks are correlated. The results for instance indicate that a medium sized innovative firm with 250 employees has a propensity to register trademark of $77 \%$. It is thus more than twice as likely to register trademarks, as a non-innovative firm. So, what are the circumstances under which trademarks are important for a firm? Overall, the results show that firms are more likely to register trademarks and pursue a trademarking strategy, provided that the distance to their customers is large, the product quality is not assessable, the number of competitors is small, or firms undertake R\&D activities and introduce product innovations. 


\section{A Appendix}

\section{A.1 Definition of Variables}

Table 2.4: Variable Definitions

\begin{tabular}{|c|c|}
\hline Variable & Definition \\
\hline Trademarks & $\begin{array}{l}\text { Dummy variable taking value } 1 \text {, if firm has at least one registered } \\
\text { trademark in } 2010 .\end{array}$ \\
\hline Firm Size & Log of the number of employees (in 2010). \\
\hline Group & $\begin{array}{l}\text { Dummy variable taking value } 1 \text {, if firm reports to be part of an enterprise } \\
\text { group in } 2010 .\end{array}$ \\
\hline East & $\begin{array}{l}\text { Dummy variable taking value } 1 \text {, if firm is located in East Germany (the } \\
\text { former territory of the GDR and West-Berlin). }\end{array}$ \\
\hline Firm Age & Log of the number of years (in 2010) since the enterprise was founded. \\
\hline Few Customers & $\begin{array}{l}\text { Dummy variable taking value } 1 \text {, if a firms' reported share of sales in } 2010 \\
\text { with the largest } 3 \text { customers is among the highest } 15 \text { percent of all sample } \\
\text { firms. }\end{array}$ \\
\hline Many Customers & $\begin{array}{l}\text { Dummy variable taking value } 1 \text {, if a firms' reported share of sales in } 2010 \\
\text { with the largest } 3 \text { customers is below the median value of all sample firms. }\end{array}$ \\
\hline Regional Market & $\begin{array}{l}\text { Dummy variable taking value } 1 \text {, if firm reports to be active on the } \\
\text { regional market, defined as the area within a radius of } 50 \mathrm{~km} \text {. }\end{array}$ \\
\hline National Market & $\begin{array}{l}\text { Dummy variable taking value } 1 \text {, if firm reports to be active on the } \\
\text { national market (Germany). }\end{array}$ \\
\hline International Market & $\begin{array}{l}\text { Dummy variable taking value } 1 \text {, if firm reports to be active on the } \\
\text { international market. }\end{array}$ \\
\hline Quality Assessable & $\begin{array}{l}\text { Dummy variable taking value } 1 \text {, if firm reports that its market is } \\
\text { characterized by the fact that customers have no difficulties to assess the } \\
\text { quality of products. }\end{array}$ \\
\hline $\begin{array}{l}\text { Products } \\
\text { tutable }\end{array}$ & $\begin{array}{l}\text { Dummy variable taking value } 1 \text {, if firm states it applies fully that it } \\
\text { operates in a market in which products are substitutable. }\end{array}$ \\
\hline Few Competitors & $\begin{array}{l}\text { Dummy variable taking value } 1 \text {, if firm reports to have up to } 5 \\
\text { competitors on its main product market in } 2010 \text {. }\end{array}$ \\
\hline Many Competitors & $\begin{array}{l}\text { Dummy variable taking value } 1 \text {, if firm reports to have more than } 50 \\
\text { competitors on its main product market in } 2010 \text {. }\end{array}$ \\
\hline Continuous R\&D & $\begin{array}{l}\text { Dummy variable taking value } 1 \text {, if firm reports to have continuous } R \& D \\
\text { activities during } 2008-2010 \text {. }\end{array}$ \\
\hline EPO Patent & Dummy variable taking value 1 , if firm has at least one patent application. \\
\hline Process Innovation & $\begin{array}{l}\text { Dummy variable taking value } 1 \text {, if firm introduced a process innovation } \\
\text { during } 2008-2010 .\end{array}$ \\
\hline Product Innovation & $\begin{array}{l}\text { Dummy variable taking value } 1 \text {, if firm introduced a product innovation } \\
\text { during } 2008-2010 \text {. }\end{array}$ \\
\hline
\end{tabular}




\section{A.2 Descriptive Statistics}

Table 2.5: Descriptive Statistics of Main Variables (Part 1)

\begin{tabular}{lrrrr}
\hline & Mean & SD & Min & Max \\
\hline Basic Characteristics & & & & \\
Firm Size & 3.58 & 1.62 & -0.13 & 10.22 \\
Group (D) & 0.29 & 0.45 & 0.00 & 1.00 \\
East Germany (D) & 0.32 & 0.47 & 0.00 & 1.00 \\
Firm Age & 3.11 & 0.86 & 0.00 & 6.52 \\
\hline Sector Affiliation & & & & \\
Food/Beverage/Tobacco & 0.04 & 0.20 & 0.00 & 1.00 \\
Textile/Clothes/Leather & 0.03 & 0.17 & 0.00 & 1.00 \\
Wood/Paper & 0.03 & 0.17 & 0.00 & 1.00 \\
Chemicals/Pharmaceuticals & 0.04 & 0.18 & 0.00 & 1.00 \\
Rubber-/Plastics products & 0.03 & 0.17 & 0.00 & 1.00 \\
Glass/Clay/Stone & 0.02 & 0.15 & 0.00 & 1.00 \\
Metal & 0.07 & 0.25 & 0.00 & 1.00 \\
Machinery & 0.07 & 0.26 & 0.00 & 1.00 \\
Electronics & 0.07 & 0.26 & 0.00 & 1.00 \\
Motor vehicles & 0.03 & 0.16 & 0.00 & 1.00 \\
Furnit./Toys/Medic. instr./Repair & 0.03 & 0.18 & 0.00 & 1.00 \\
Water/Waste disposal/Recycling & 0.05 & 0.22 & 0.00 & 1.00 \\
Energy/Mining/Petroleum & 0.04 & 0.19 & 0.00 & 1.00 \\
Wholesale & 0.04 & 0.19 & 0.00 & 1.00 \\
Transportation/Postal services & 0.07 & 0.25 & 0.00 & 1.00 \\
Media services & 0.04 & 0.20 & 0.00 & 1.00 \\
IT/Telecommunication & 0.05 & 0.22 & 0.00 & 1.00 \\
Financial services & 0.03 & 0.17 & 0.00 & 1.00 \\
Consultancy/Advertising & 0.05 & 0.22 & 0.00 & 1.00 \\
Technical/R\&D services & 0.07 & 0.26 & 0.00 & 1.00 \\
Corporate services & 0.06 & 0.23 & 0.00 & 1.00 \\
\hline
\end{tabular}

Source: ZEW: Mannheim Innovation Panel, survey 2011. 


\section{A.3 Descriptive Statistics}

Table 2.6: Descriptive Statistics of Main Variables (Part 2)

\begin{tabular}{lcccc}
\hline & Mean & SD & Min & Max \\
\hline Personal Distance & & & & \\
Few Customers (D) & 0.15 & 0.36 & 0.00 & 1.00 \\
Many Customers (D) & 0.45 & 0.50 & 0.00 & 1.00 \\
\hline Geographical Distance & & & & \\
Regional Market (D) & 0.63 & 0.48 & 0.00 & 1.00 \\
National Market (D) & 0.71 & 0.45 & 0.00 & 1.00 \\
International Market (D) & 0.47 & 0.50 & 0.00 & 1.00 \\
\hline Product Quality & & & & \\
Quality Assessable (D) & 0.22 & 0.42 & 0.00 & 1.00 \\
\hline Substitutability & & & & \\
Products Substitutable (D) & 0.21 & 0.41 & 0.00 & 1.00 \\
Few Competitors (D) & 0.42 & 0.49 & 0.00 & 1.00 \\
Many Competitors (D) & 0.19 & 0.39 & 0.00 & 1.00 \\
\hline Innovation & & & & \\
Continuous R\&D (D) & 0.22 & 0.41 & 0.00 & 1.00 \\
EPO Patent (D) & 0.12 & 0.33 & 0.00 & 1.00 \\
Process Innovation (D) & 0.32 & 0.47 & 0.00 & 1.00 \\
Product Innovation (D) & 0.44 & 0.50 & 0.00 & 1.00 \\
\hline
\end{tabular}

Source: ZEW: Mannheim Innovation Panel, survey 2011. 


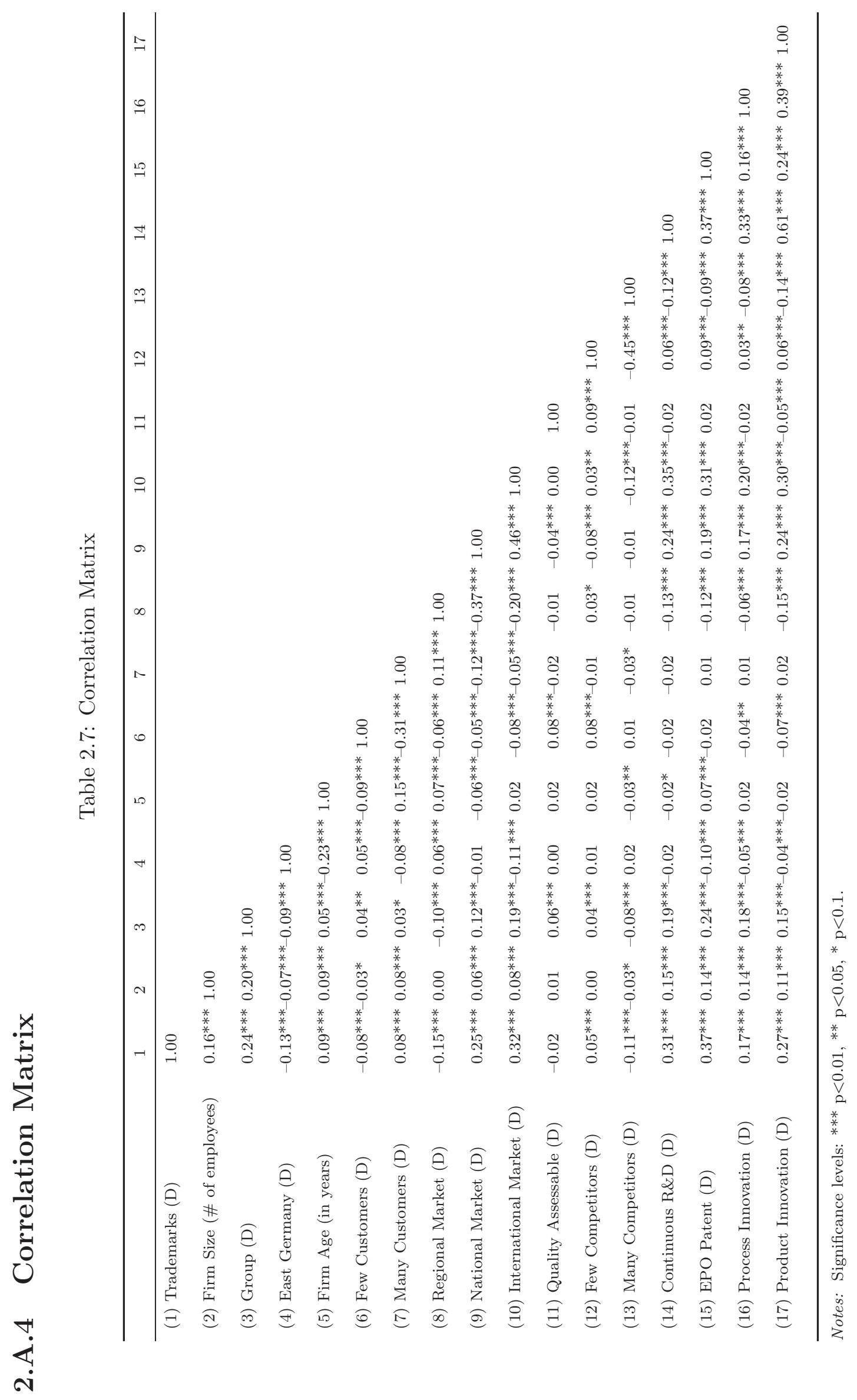


Table 2.8: Weighted Regression: The Propensity to Trademark

\begin{tabular}{|c|c|c|c|c|}
\hline & \multicolumn{2}{|c|}{$\begin{array}{c}(1) \\
\text { Trademarks (D) }\end{array}$} & \multicolumn{2}{|c|}{$\begin{array}{c}(2) \\
\text { Trademarks (D) }\end{array}$} \\
\hline & $\beta / \mathrm{SE}$ & $\mathrm{ME}$ & $\beta / \mathrm{SE}$ & ME \\
\hline \multicolumn{5}{|l|}{ Basic Characteristics } \\
\hline Firm Size & $\begin{array}{l}0.243^{* * *} \\
(0.017)\end{array}$ & $0.062^{* * *}$ & $\begin{array}{l}0.345^{* * *} \\
(0.041)\end{array}$ & $0.067^{* * *}$ \\
\hline Group & $\begin{array}{c}0.036 \\
(0.051)\end{array}$ & 0.009 & $\begin{array}{c}0.055 \\
(0.114)\end{array}$ & 0.011 \\
\hline East Germany & $\begin{array}{l}-0.180^{* * *} \\
(0.047)\end{array}$ & $-0.046^{* * *}$ & $\begin{array}{l}-0.082 \\
(0.090)\end{array}$ & -0.016 \\
\hline Firm Age & $\begin{array}{c}0.013 \\
(0.026)\end{array}$ & 0.003 & $\begin{array}{l}-0.048 \\
(0.047)\end{array}$ & -0.009 \\
\hline \multicolumn{5}{|l|}{ Personal Distance } \\
\hline Few Customers & $\begin{array}{l}-0.159^{* *} \\
(0.066)\end{array}$ & $-0.039 * *$ & $\begin{array}{l}-0.262^{* *} \\
(0.123)\end{array}$ & $-0.045^{* *}$ \\
\hline Many Customers & $\begin{array}{l}0.146^{* * *} \\
(0.046)\end{array}$ & $0.038^{* * *}$ & $\begin{array}{c}0.107 \\
(0.090)\end{array}$ & 0.021 \\
\hline \multicolumn{5}{|l|}{ Geographical Distance } \\
\hline Regional Market & $\begin{array}{l}-0.177^{* * *} \\
(0.044)\end{array}$ & $-0.046^{* * *}$ & $\begin{array}{l}-0.229^{* * *} \\
(0.086)\end{array}$ & $-0.046^{* * *}$ \\
\hline National Market & $\begin{array}{l}0.401^{* * *} \\
(0.059)\end{array}$ & $0.101^{* * *}$ & $\begin{array}{l}0.553^{* * *} \\
(0.120)\end{array}$ & $0.101^{* * *}$ \\
\hline International Market & $\begin{array}{l}0.353^{* * *} \\
(0.049)\end{array}$ & $0.094^{* * *}$ & $\begin{array}{l}0.337^{* * *} \\
(0.093)\end{array}$ & $0.069^{* * *}$ \\
\hline \multicolumn{5}{|l|}{ Product Quality } \\
\hline Quality Assessable & $\begin{array}{l}-0.138^{* * *} \\
(0.051)\end{array}$ & $-0.035 * * *$ & $\begin{array}{c}-0.192^{*} \\
(0.104)\end{array}$ & $-0.036^{*}$ \\
\hline \multicolumn{5}{|l|}{ Substitutability } \\
\hline Products Substitutable & $\begin{array}{l}-0.036 \\
(0.054)\end{array}$ & -0.009 & $\begin{array}{c}0.016 \\
(0.105)\end{array}$ & 0.003 \\
\hline Few Competitors & $\begin{array}{l}0.093^{* *} \\
(0.046)\end{array}$ & $0.024^{* *}$ & $\begin{array}{l}0.270^{* * *} \\
(0.088)\end{array}$ & $0.057^{* * *}$ \\
\hline Many Competitors & $\begin{array}{l}-0.173^{* * *} \\
(0.060)\end{array}$ & $-0.043^{* * *}$ & $\begin{array}{l}-0.221^{* *} \\
(0.112)\end{array}$ & $-0.038^{* *}$ \\
\hline \multicolumn{5}{|l|}{ Innovator } \\
\hline Continuous R\&D & $\begin{array}{l}0.208^{* * *} \\
(0.062)\end{array}$ & $0.056^{* * *}$ & $\begin{array}{l}0.235^{* *} \\
(0.111)\end{array}$ & $0.049^{* *}$ \\
\hline EPO Patent & $\begin{array}{l}0.800^{* * *} \\
(0.069)\end{array}$ & $0.240^{* * *}$ & $\begin{array}{l}0.705^{* * *} \\
(0.119)\end{array}$ & $0.173^{* * *}$ \\
\hline Process Innovation & $\begin{array}{c}-0.042 \\
(0.047)\end{array}$ & -0.011 & $\begin{array}{c}-0.035 \\
(0.083)\end{array}$ & -0.007 \\
\hline Product Innovation & $\begin{array}{l}0.203^{* * *} \\
(0.052)\end{array}$ & $0.053^{* * *}$ & $\begin{array}{c}0.016 \\
(0.087)\end{array}$ & 0.003 \\
\hline W_Industry & 0.000 & & 0.000 & \\
\hline McFadden's R2 & 0.263 & & 0.247 & \\
\hline McFadden's Adj R2 & 0.247 & & 0.247 & \\
\hline Correctly Classified (\%) & 75.275 & & & \\
\hline Correctly Classified 1 (\%) & 74.342 & & & \\
\hline Correctly Classified $0(\%)$ & 75.699 & & & \\
\hline Observations & 5464 & & 5464 & \\
\hline
\end{tabular}

Notes: Column (1) provides results of an unweighted regression and Column 2 of a weighted regression. Source: ZEW: Mannheim Innovation Panel, survey 2011. 



\section{Chapter 3}

\section{The Impact of Brand Use on Innovation Performance - Empirical Results for Germany}

\subsection{Introduction}

Innovative firms aim to transfer their R\&D and other related investments into successful innovations. The success of innovations requires both: the successful completion of the research and development process, resulting in a new or improved product, as well as the acceptance of the product in the market, resulting in commercial success for the firm. Following Griliches (1979), intangible capital affecting innovation success is mainly shown to be determined by the technological side. Innovation success is influenced by a firms investment in innovation, its technological capabilities, its absorptive capacities, and the use of external knowledge (Cohen and Levinthal, 1990; Crépon et al., 1998; Lööf and Heshmati, 2002; Peters and Schmiele, 2011; Peters, 2008; Hall and Mairesse, 2006).

According to this framework, new technology enables the creation of new or improved functional product attributes that speak for themselves. This is at odds with the observation that (potential) customers are not perfectly informed about quality characteristics, prices, or even the existence of product innovations. Consequently, considerable marketing activities might be necessary to overcome information asymmetries in the market. This is in line with the finding that marketing expenditures are responsible for large parts of expenditures for launching innovations (Pavitt, 1985). ${ }^{5}$ In other words, while a firm's technological abilities make a product innovation possible, this product may face a lack of interest among potential customers after its market introduction. Aaker (2007) points out that the branding of an innovation "can make all the difference." This difference, according

\footnotetext{
${ }^{5}$ Costs associated with the market introduction of product innovations (including expenses for market tests) amount... on total innovation expenditure ... 8\% ... (Licht and Stahl, 1997)
} 
to his reasoning, can be the result of several factors: Branding helps to "make the innovation visible" by attracting interest and recognition. Branding is furthermore able to add credibility to the product innovation and makes "communication more efficient". The branding of product innovations also provides "the potential to own the innovation". A competitor might offer an imitation of the product innovation, but "will need to overcome the power of the brand" (Aaker, 2007). In this sense, branding can be an effective strategy to appropriate the returns of an innovation (Amara et al., 2008). To sum up, branding might play a crucial role during the commercialisation and might have an important impact on the economic success of a firm's product innovation.

The aim of this paper is to investigate the performance effects of branding on a firm's innovation success. First, I investigate whether the brand strategy of a firm affects the introduction of new products. Second, given that a firm has decided to introduce new product(s), I analyse whether brands are conducive to innovation success, measured in terms of sales with new products. When a firm introduces a new product, it has to make two choices. First, whether the new product is introduced with or without a brand and if it opts for a brand, whether it relies on an established brand or creates a new brand.

Previous studies provide evidence that brands improve a firm's market valuation, productivity and profitability (Sandner and Block, 2011; Crass and Peters, 2014; Griffiths et al., 2011; Crass et al., 2014). To the best of my knowledge, there is no large-scale evidence about the impact of brands on the commercial performance of product innovations. The impact of well-known brands like Coca-Cola, Apple, Google, or Mercedes on the commercial performance of corresponding product innovations supports a positive impact. These global brands are, however, not necessarily representative for the entire economic sector. Do firms on average profit from a branding strategy? This study aims to provide empirical evidence to fill the research gap on the impact of brands on innovation performance by using a representative sample of German firms.

Firm-level data is obtained from the Mannheim Innovation Panel (MIP), which is the official innovation Survey in Germany, based on a stratified random sample of legally independent firms in the business sector with at least five employees. In addition to various innovation indicators, the 2011 survey provides unique information on firms' branding strategies. Firms were asked whether their product innovations were introduced without a brand, under an established brand or a new brand. MIP firmlevel data is furthermore augmented by information on firms' trademark registrations at the German as well as the European trademark office.

Results show that firms achieve larger performance effects with branded product innovations than with unbranded ones. Beyond this, firms that pursue a brand strategy, have a higher propensity to innovate in terms of the introduction of a product innovation. 


\subsection{Determinants of Innovation Performance}

Innovation performance has several dimensions and can be measured quite differently. Common measures of innovation output are patent applications, the introduction of product and process innovations, cost reductions due to process innovations and the share of sales with innovative products. Patents are indicators for the success of a firm's research activities. A patent indicates that a firm has achieved a new technical invention, that is commercially applicable and has a sufficient level of inventiveness. These inventions are not equivalent to new products. A technological invention becomes a product innovation only if "it has processed through production and marketing tasks and is diffused into the marketplace" (Garcia and Calantone, 2002). However, product innovations do not have to be based on patents. In fact, just 31\% of German firms with product or process innovations used patents to protect their intellectual property (Aschhoff et al., 2013). The introduction of a product innovation constitutes an indicator of innovation success, which emphasizes in particular the commercially useful output. The commercial success is measured through a firm's sales share with its product innovations. The share of innovative sales in total turnover captures, in contrast to traditional patent indicators, "a direct link between the innovation effort and commercial success" (Chudnovsky et al., 2006).

Each product innovator thus has to manage both: the development of a new product, possibly based on a technological invention as well as the commercial success of the product innovation in the marketplace. Both stages are risky and only a fraction of product launches are successful (Hauser et al., 2006). Firms are interested in maximizing their chances of success. In the following I discuss factors that are supposed to enhance the probability of success.

\subsubsection{Investment in Innovation}

One of the most important determinants of innovation performance is the extent to which a firm invests in innovation (Crépon et al., 1998; Mairesse and Mohnen, 2002; Griffith et al., 2006). The greater a firm's efforts in innovation activities, the larger the probability of having a product innovation and the larger on average the innovation performance.

The acquisition of external knowledge is crucial to improve a firm's innovation performance. Internal R\&D activities are more efficient, if they are combined with external sources. Cassiman and Veugelers (2006) provide empirical evidence for the complementarity of internal R\&D and external knowledge-acquisition activities. They show that external R\&D, that is R\&D that is contracted out to third parties has a positive effect on the marginal return of internal $R \& D$, and vice versa. However, outsourcing of $R \& D$ can also have a negative impact on innovation per- 
formance. Grimpe and Kaiser (2010) argue that "over-outsourcing" constitutes a serious risk to a firm's innovation success but the negative effects can be mitigated through the extent of internal R\&D and the breadth of research collaborations. This finding emphasizes the importance of balancing internal and external innovation activities to maintain a firm's "absorptive capacity" (Cohen and Levin, 1989), which is based on its stock of prior knowledge. These findings also point to cooperation as another source of external knowledge.

Research and development $(\mathrm{R} \& \mathrm{D})$ alliances opens a wide range of external knowledge sources. A firm might cooperate with competitors, suppliers, customers, and universities and research institutes to acquire relevant external knowledge for the innovation process. Laursen and Salter (2006) emphasize the role of a firm's search strategy for new ideas that have a high potential for commercial success. They find that firms who are more open to external sources have more commercial success with their product innovations. Many firms are involved in multiple cooperation alliances. Synergy effects and complementary knowledge from different sources can increase the impact on innovation success (Belderbos et al., 2004; Leiponen and Helfat, 2010). The diversity of cooperation partners increases the effect of R\&D alliances (van Beers and Zand, 2014).

Given that many product innovations fail, a firm is most successful if it pursues several innovation projects (Hauser et al., 2006). The underlying idea is quite simple: Pursuing several innovation projects increases the probability that at least one of them will be successful. Klingebiel and Rammer (2014) investigate the effect of different resource allocation strategies on innovation performance. They find that breadth in resource allocation increases innovation performance, that is the more projects, the higher is the likelihood of some innovation success. According to their findings, firms achieve greater performance if they allocate their financial resources initially to a broad range of projects and discontinue less successful projects in later stages, leading to the selection of the most successful projects.

To sum up, prior literature has shown that innovation performance is influenced by the investment in research and development, the various ways to acquire knowledge, and the way to design the innovation process. Apart from these closely innovationrelated factors, a number of other factors are found to be relevant. Hall et al. (2013) find, for example, that investment in information and communication technology (ICT) is strongly associated with innovation success. They treat ICT in parallel with R\&D as an input to innovation and find both to contribute to a firm's innovation performance.

Another crucial asset for firm performance is brand equity. Brand equity is shown to add to the overall performance of a firm, particularly in terms of productivity, profitability and market value (Srinivasan et al., 2011; Griffiths et al., 2011; Sandner and Block, 2011; Crass and Peters, 2014; Crass et al., 2014), but its contribution to innovation performance is empirically less clear. 


\subsubsection{Brand Use}

Once the firm has managed to achieve market readiness of a new or significantly improved product, the firm has to decide whether it introduces the product innovation under a brand and if so, whether it makes use of a new or an established brand. The market introduction under a brand might enhance the economic success of the product innovation. The brand could even make "all the difference" (Aaker, 2007). This might be due to the fact that a brand generates attention to the product innovation, adds reputation and credibility, and helps to appropriate the returns from the innovation.

Independently of how well a product innovation might meet the needs of customers, they have to be aware of it to purchase it (Srinivasan et al., 2005). Branding helps to make the innovation visible by attracting interest and recognition (Aaker, 2007). In this sense, the product innovation can achieve higher awareness and is easier to remember.

A product innovation has per definition significant new features or is even completely new. The target audience has no experience with the particular product innovation and might face uncertainty about its (new) features. The good experience that consumers may have had with previous purchases of the brand is likely to induce them to transmit their confidence in the brand to the product innovation. Established brands are thus able to add reputation and credibility to new products.

An established brand differs from a new brand in its already established reputation among the target audience. Building a new brand takes time and is associated with considerably costs. The use of a new brand to introduce new products into the market might therefore be less powerful and positive effects might occur not immediately but only in the medium and long term. The use of an established brand to introduce a new product has advantages, since its reputation and awareness can be attached to a new product immediately, the chances of success are higher and marketing costs are lower. A firm might, regardless of the advantages of an established brand, decide to use a new brand. Apart from the possibility that the firm does not have an established brand, there are two main reasons to use a new brand. First, an established brand can fail to help a new product. This might be the case if the new product does not fit to the perceptions of the consumers about the established brand. Second, a new product can damage the original brand by adding undesired associations (Aaker, 1991; Srinivasan et al., 2011).

Most product innovations can be imitated by competitors. If the product innovation is linked in the minds of the consumers to the brand, then the brand becomes an integral feature of the product itself. In this case, a competitor not only has to imitate the product, but also to overcome the power of the brand (Aaker, 2007). Since a firm can protect its brands by trademarks, which can be renewed indefinitely, the power of the brand might constitute a long-term competitive advantage over 
competitors. ${ }^{6}$ This means that the branding of a product innovation provides the potential to better appropriate the returns from innovation because the innovator can achieve a legally protected monopoly over its brand. Hence I expect firms which use brands for product innovations to have a higher innovation success.

\subsection{Data and Variables}

\subsubsection{Data Sets}

Most of the firm-level data come from the Mannheim Innovation Panel, which constitutes the German contribution to the European Community Innovation Survey (CIS). The survey is a stratified random sample (by sector, size, and region) that targets the population of all German firms with at least five employees in manufacturing and service industries. The survey is conducted annually since 1993 by the Centre for European Economic Research (ZEW) in collaboration with infas Institute for Applied Social Sciences and the Fraunhofer Institute for Systems and Innovation Research (ISI) on behalf of the feral ministry of education and research. It asks firms to report general and innovation related information covering the prior three years. So, for instance, the 2011 survey used here collected data for 2008, 2009, and 2010. (OECD, Eurostat, 2005). CIS methodology and questionnaires are internationally harmonized across the countries and based on the so-called Oslo Manual (OECD, Eurostat, 2005). German CIS data provide an additional layer of quality through extensive nonresponse surveys and are considered to be of high quality (Eurostat, 2013). Further information on the survey methodology, data, and validity is provided by Peters (2008), Aschhoff et al. (2013), and Peters and Rammer (2013). This study combines the German CIS information of the 2011 survey with administrative data on each firm's trademark and patenting activity. The trademark data comes from the Office for Harmonization in the Internal Market (OHIM) and the German Patent and Trade Mark Office (DPMA). The OHIM data reflect trademarks valid in all European Union (EU) member states while the DPMA trademarks are specific to Germany. The patent data come from the European Patent Office (EPO) and Germany's DPMA. All administrative data were matched to the German CIS using assignee name and address information and specialized software developed at the Centre for European Economic Research.

The sample consists of 6,844 firms for which information of their innovation activities is available. The German part of the Community Innovation Survey (CIS) offers some flexibility for additional questions in addition to the core questions of the harmonized CIS questionnaire. This flexibility was used in 2011 to include a set of

\footnotetext{
${ }^{6}$ The owner of a trademark is given a legal monopoly over the protected word, sign, symbol or other graphical representation in connection with the attached commodity (Economides, 1998; Baroncelli et al., 2004).
} 
questions on a firm's branding strategy.

\subsubsection{Product Innovation Performance}

The first dependent variable is a binary indicator for product innovators i.e. firms that have managed to introduce a product innovation into the market between 2008 and 2010. The commercial success of these product innovations is captured through a firm's revenue derived from new product sales in 2010. This second measure reflects the acceptance of the innovation in the market and provides a direct link between product innovations and their commercial performance (Chudnovsky et al., 2006; Mairesse and Mohnen, 2010).

A product innovation is defined as the market introduction of a new or significantly improved good or service, which is either new or significantly improved with respect to its fundamental characteristics or technical components. The innovation has to be new to the firm, not necessarily new to the market. This definition captures quite different degrees of innovativeness, which can be further distinguished between market novelties (new-to-the-market products) and firm novelties (product imitations). Market novelties are product innovations that have been launched onto the market by a firm prior to any competitor. Imitative product innovations are defined to be new to the firm, but not new to the market (Garcia and Calantone, 2002). The survey design furthermore allows to distinguish between firm's revenue from new-to-market product sales and new-to-firm (imitative) product sales. The questionnaire provides the percentage of firm sales derived from the introduction of product innovations, as well as the percentage of new-to-market product sales in 2010. The difference between these two values is, by definition, the percentage of imitative product innovations.

Several studies have used the share of sales with product innovations as dependent variable (Crépon et al., 1998; Chudnovsky et al., 2006; Mairesse and Mohnen, 2010; Grimpe and Kaiser, 2010). One can argue that with respect to the dependent variable more should always be better. However, a higher percentage of sales with innovative products does not automatically imply better performance. Particularly smaller and single product firms quickly achieve high intensities. Klingebiel and Rammer (2014) therefore propose the use of raw values. The percentage shares are multiplied by a firm's total sales, to obtain the raw Euro value of a firm's product innovation sales. This study follows their suggestion and uses the percentage shares only as a robustness-check.

About $38 \%$ of the sample firms introduced at least one product innovation between 2008 and 2010. About 18\% introduced at least one market novelty and $32 \%$ at least one product imitation. The innovators in the sample generate on average 26.8 percent of total turnover with new or improved products. About 7.6 percent of total turnover result from new-to-market product innovations and the remaining 
19.2 percent from product imitations.

\subsubsection{The Use of Brands for Product Innovations}

As explained in the previous section, brands might play an important role in the commercialization phase of product innovations. The CIS 2011 survey provides unique information about the branding strategy related to product innovation. In addition to the core CIS questions, German firms were asked to report whether its product innovations were introduced without a brand, under an established brand or a new brand. Three dummy variables have been constructed, which indicate whether a firm's product innovation was introduced under an established brand, under a new brand or (the reference category) without any branding.

Table 3.1: Brand Usage of Product Innovators

\begin{tabular}{lccc}
\hline Sector & Establ. Brand & New Brand & No Brand \\
\hline Mining & 0.00 & 0.20 & 0.80 \\
Low-tech manufacturing & 0.26 & 0.15 & 0.61 \\
High-tech manufacturing & 0.34 & 0.19 & 0.52 \\
Energy, water, recycling & 0.15 & 0.09 & 0.79 \\
Construction & 0.20 & 0.00 & 0.80 \\
Wholesale & 0.42 & 0.15 & 0.42 \\
Transportation & 0.10 & 0.04 & 0.87 \\
Information and Communication & 0.29 & 0.13 & 0.62 \\
Financial Services & 0.10 & 0.05 & 0.85 \\
Consulting, Advertising & 0.17 & 0.05 & 0.78 \\
Engineering/R\&D services & 0.15 & 0.07 & 0.80 \\
Other business services & 0.09 & 0.02 & 0.89 \\
\hline Total & 0.26 & 0.14 & 0.62 \\
\hline
\end{tabular}

Source: ZEW: Mannheim Innovation Panel, survey 2011.

Table 3.1 depicts descriptive statistics on the usage of branding strategies related to the introduction of new products. It turns out that the majority, $62 \%$ of product innovators, do not rely on brands at all when they introduce new products into the marketplace. About $14 \%$ of the product innovators attempt to introduce a product innovation under a new brand and $26 \%$ rely on an established brand. Only a small group of $2.5 \%$ of the firms use both, new and established brands. A differentiation by sector affiliation shows a high degree of heterogeneity of brand usage across different industries. Branding of product innovations is most common in the wholesale sector, where around $60 \%$ of the product innovators use a brand name for their innovations, followed by the high-tech manufacturing sector (with around 50\%), the low-tech manufacturing sector and the information and communication sector (both with around 40\%). Branding of product innovations has only a minor importance within the so-called other business service sector (only about $10 \%$ use a brand name), the 
transportation sector (14\%) and the financial service sector (16\%).

Brands can be protected by trademarks. The data about trademark registration have the advantage that they provide information on past brand-related activities. The binary variable trademark makes use of the information on a firm's trademark history and takes the value 1 , if the firm has at least one registered trademark in 2007. The year 2007 refers to the year prior to the period 2008 to 2010 in which the product innovation is captured.

Brands are built over time through a variety of management choices such as expenditures on advertising, promotions, market research, loyalty programs, distribution channel development, product-quality and customer service efforts, and new product development (Kirk et al., 2013). Marketing expenditures capture an important part of these expenses, including all in-house and contracted out expenditures for advertising and branding, reputation building, conceptual design of marketing strategies, market and costumer research, and the installation of new distribution channels. A firm's marketing intensity is measured as a firm's marketing expenditure per employee.

\subsubsection{Control variables}

The model contains a number of control variables that might influence innovation performance and are frequently used as explanatory variables (Crépon et al., 1998; Grimpe and Kaiser, 2010; Klingebiel and Rammer, 2014; Mairesse and Mohnen, 2002). The number of employees (in logs) accounts for firm size and sales per employee for a firm's level of productivity in 2008. One of the most important determinants of innovation performance is innovation effort. The more a firm spends on innovation, the more product and process innovations might be developed. Innovation intensity, measured as the total amount of innovation expenditure per employee, is therefore included as additional control variable in order to account for differences in innovation effort. The dummy variable process innovation indicates whether innovation expenditures are at least partly assigned to process innovations. The stock of prior knowledge creates the basis for a firm's "absorptive capacity" (Cohen and Levin, 1989), which is captured through a firm's patent stock and a dummy variable, indicating continuous $R \mathscr{E} D$ activities. $R \& D$ is conducted on a continuous base by about half of the product innovating firms. Whether a firm does R\&D continuously is direct information from the survey. The patent stock is calculated from the annual time series of patent applications at the European Patent Office using the perpetual inventory method with a discount factor of 0.15 (Griliches and Mairesse, 1984; Hall, 1999). Roughly one out of five product innovater (23\%) have patent applications. Taking the logarithm of the patent stock yields missing values for all observations with no patents at all. The value of these missings is set to zero and a dummy variable indicating a firm without patents is added in the regression. 
The acquisition of external knowledge is captured by two dummy variables. The first dummy variable external $R E \mathcal{E}$ indicates that a firm contracts $R \& D$ out and the second dummy variable cooperation indicates that a firm has innovation alliances with competitors, suppliers, customers, or universities and research institutes.

Human capital is an important input factor in a firm's innovation process. High skilled labour, the proportion of employees with a university degree, captures an important dimension of human capital in firms. About $25 \%$ of the employees of product innovating firms have a university degree, while this proportion is considerably smaller for non-product innovators at about $15 \%$. The typical length of a firm's product life cycle is supposed to have an influence on the frequency of a firm's market introductions. The shorter the typical life cycle of products is, the larger should be the sales share with its product innovations. To control for the typical life cycle, I make use of a firm's assessment of whether its products are quickly outdated. The survey asked respondents to state on a four-point Likert scale (zero=does not apply at all, to three=does apply fully) whether the firm's most important products and services are quickly outdated. The variable quickly outdated represents the industry average of firms that have marked the highest category.

I also control for several basic firm characteristics. Firm age is measured as the log of years since the firm's foundation. A region dummy indicates whether the firm's headquarter is located in East Germany and an exporter dummy whether the firm serves international markets. Firms which belong to a group of companies can make use of the resources of the group and thus gain from synergy (dis)advantages. Increased intragroup synergies can lead to higher innovation output. An indicator variable group is therefore included. Furthermore, I include 12 industry dummies to control for industry characteristics that are not measured by the other structural variables. Firms are assigned to these industries on the basis of their most important activity. Detailed descriptions of the variables are provided in Table 3.6 in the Appendix. 
Table 3.2: Descriptive Statistics of Main Variables

\begin{tabular}{|c|c|c|c|c|c|c|}
\hline & \multicolumn{2}{|c|}{$\begin{array}{c}(1) \\
\text { Full sample }\end{array}$} & \multicolumn{2}{|c|}{$\begin{array}{c}(2) \\
\text { Innovators }\end{array}$} & \multicolumn{2}{|c|}{$\begin{array}{c}(3) \\
\text { Innov. vs. Non-Innov. }\end{array}$} \\
\hline & Mean & $\mathrm{SE}$ & Mean & SE & Diff & $\mathrm{SE}$ \\
\hline Product Innovation (D) & 0.38 & $(0.01)$ & 1.00 & $(0.00)$ & 1.00 & $(0.00)$ \\
\hline Sales Product Innovations & 6.41 & $(1.24)$ & 17.25 & $(3.31)$ & $17.25^{* * *}$ & $(2.54)$ \\
\hline Sales Share Innovations & 10.05 & $(0.32)$ & 26.80 & $(0.66)$ & $26.80^{* * *}$ & $(0.51)$ \\
\hline Market Novelty (D) & 0.18 & $(0.01)$ & 0.49 & $(0.01)$ & $0.49^{* * *}$ & $(0.01)$ \\
\hline Sales Market Novelties & 1.40 & $(0.23)$ & 3.77 & $(0.61)$ & $3.77^{* * *}$ & $(0.47)$ \\
\hline Sales Share Market Novelties & 2.84 & $(0.16)$ & 7.57 & $(0.41)$ & $7.57^{* * *}$ & $(0.31)$ \\
\hline Imitative Innovation (D) & 0.32 & $(0.01)$ & 0.84 & $(0.01)$ & $0.84^{* * *}$ & $(0.01)$ \\
\hline Sales Product Imitations & 5.01 & $(1.12)$ & 13.48 & $(3.00)$ & $13.48^{* * *}$ & $(2.30)$ \\
\hline Sales Share Imitation Product & 7.21 & $(0.26)$ & 19.22 & $(0.58)$ & $19.22^{* * *}$ & $(0.45)$ \\
\hline Innovation intensity & 0.00 & $(0.00)$ & 0.01 & $(0.00)$ & $0.01^{* * *}$ & $(0.00)$ \\
\hline High Skilled Labour & 18.35 & $(0.37)$ & 24.28 & $(0.68)$ & $9.49^{* * *}$ & $(0.76)$ \\
\hline Process Innovation (D) & 0.29 & $(0.01)$ & 0.52 & $(0.01)$ & $0.37^{* * *}$ & $(0.01)$ \\
\hline Patent stock (ln) & 0.00 & $(0.01)$ & 0.08 & $(0.02)$ & $0.13^{* * *}$ & $(0.02)$ \\
\hline Patent stock: zero & 0.88 & $(0.01)$ & 0.77 & $(0.01)$ & $-0.18^{* * *}$ & $(0.01)$ \\
\hline Continuous R\&D (D) & 0.21 & $(0.01)$ & 0.48 & $(0.01)$ & $0.43^{* * *}$ & $(0.01)$ \\
\hline External R\&D (D) & 0.15 & $(0.01)$ & 0.32 & $(0.01)$ & $0.27^{* * *}$ & $(0.01)$ \\
\hline Cooperation (D) & 0.21 & $(0.01)$ & 0.25 & $(0.01)$ & $0.06^{* * *}$ & $(0.01)$ \\
\hline Marketing intensity & 0.00 & $(0.00)$ & 0.00 & $(0.00)$ & $0.00^{* * *}$ & $(0.00)$ \\
\hline Established Brand (D) & 0.10 & $(0.00)$ & 0.26 & $(0.01)$ & $0.26^{* * *}$ & $(0.01)$ \\
\hline New Brand (D) & 0.05 & $(0.00)$ & 0.14 & $(0.01)$ & $0.14^{* * *}$ & $(0.01)$ \\
\hline Trademark (D, L3) & 0.29 & $(0.01)$ & 0.44 & $(0.01)$ & $0.24^{* * *}$ & $(0.01)$ \\
\hline Diversity (ln) & -4.19 & $(0.01)$ & -4.13 & $(0.01)$ & $0.10^{* * *}$ & $(0.01)$ \\
\hline divln_m & 0.07 & $(0.00)$ & 0.05 & $(0.01)$ & $-0.03^{* * *}$ & $(0.01)$ \\
\hline Market share (ln, L2) & -0.75 & $(0.07)$ & -0.13 & $(0.11)$ & $0.99^{* * *}$ & $(0.14)$ \\
\hline Missing: Market share (ln, L2) & 0.21 & $(0.01)$ & 0.16 & $(0.01)$ & $-0.08^{* * *}$ & $(0.01)$ \\
\hline Firm Size (ln \# of employees) & 3.68 & $(0.02)$ & 3.97 & $(0.04)$ & $0.46^{* * *}$ & $(0.05)$ \\
\hline Productivity (L2) & 0.20 & $(0.01)$ & 0.19 & $(0.02)$ & -0.01 & $(0.02)$ \\
\hline Exporter (D) & 0.46 & $(0.01)$ & 0.67 & $(0.01)$ & $0.34^{* * *}$ & $(0.02)$ \\
\hline Firm age & 3.15 & $(0.01)$ & 3.09 & $(0.02)$ & $-0.10^{* * *}$ & $(0.03)$ \\
\hline Quickly Outdated & 0.06 & $(0.00)$ & 0.07 & $(0.00)$ & $0.01^{* * *}$ & $(0.00)$ \\
\hline Group (D) & 0.28 & $(0.01)$ & 0.34 & $(0.01)$ & $0.10^{* * *}$ & $(0.01)$ \\
\hline East Germany (D) & 0.34 & $(0.01)$ & 0.32 & $(0.01)$ & $-0.03^{*}$ & $(0.02)$ \\
\hline
\end{tabular}

The first column provides mean and standard error of the main variables for the full sample, the second column for the subsample of product innovating firms, and the third column provides the difference between product innovating and non-product-innovating firms.

Notes: (D) denotes dummy variables. (L2) denotes two, and (L3) three year lagged variables.

Source: ZEW: Mannheim Innovation Panel, survey 2011. 


\subsection{Empirical Strategy and Results}

The study aims at shedding light on the question how brands impact innovation performance. Innovation performance, however, can be observed only for those firms that have accomplished the market introduction of a new or significantly improved product. This group of product innovators is not randomly assigned, which is why we have to address a potential selection bias. A Heckman sample selection model, which is also referred to as Tobit type II model, is estimated to control for selection bias. The model is specified with two equations: the first one explains the propensity to introduce a product innovation. Given that a firm has introduced a new product, the second equation explains the innovation performance in terms of sales with these product innovations.

In the first stage I investigate the determinants that lead to product innovations. Firms have to decide to invest in innovation and have to be successful in accomplishing the innovation process to introduce a new or significantly improved product. Following the literature of a firm's propensity to launch a product innovation (see Chapter 3.2 and studies cited therein e.g. Crépon et al., 1998; Klingebiel and Rammer, 2014), the following explanatory variables are included: firm size, lagged level of firm productivity, firm age, a firm's absorptive capability (measured by its lagged patent stock and the share of high skilled labour), the market environment (captured by the assessment whether its products are quickly outdated and whether the firm serves international markets), and whether the firm belongs to a group. Product innovations might be caused by brands (see Chapter 2). To mitigate potential endogeneity problems, I include the three-year lagged trademark indicator in the selection regression.

The specification of the selection equation should include a so-called exclusion restriction, so that the identification of the model is not based solely upon the nonlinearity in the functional form (Cameron and Trivedi, 2009). A variable which serves as exclusion restriction provides an independent source of variation in the probability to introduce innovations and does not affect innovation performance directly. A firm's market share and the degree of a firm's product diversity meet these requirements. The larger a firm's market share, the more likely it is that a firm introduces a new product while the market share does not affect the absolute amount of innovative sales. Indeed, when we additionally include market share in the second stage, we do not find a significant impact though this is not a formal test of the validity as exclusion restriction. Likewise, I expect the degree of product diversity to have an impact on the propensity to introduce a product innovation, since a more diverse firm has more "chances" to improve its products and services. Product diversity has, however, no impact on the economic success of product innovations (Crépon et al., 1998). This qualifies product diversity to serve as exclusion restriction as well. In the second stage, the factors influencing the innovation performance of a firm's 
product innovations are investigated. As the main variables of interest I add a dummy variable, which indicates the use of a brand when pacing a product innovation onto the market. The use of a brand is in the next step distinguished by two dummy variables, which indicate the introduction of a firm's product innovations under an established brand and under a new brand. Innovative success might not only be affected by the use of brands but also by marketing efforts. Even without brand usage firms can spend on marketing activities. However, firms might be more dedicated to marketing activities if they use brands. In order to separate the effect of branding from marketing expenditures, I additionally include marketing intensity. A firm's innovation activities include its innovation intensity, a dummy variable indicating that the firm conducts $\mathrm{R} \& \mathrm{D}$ on a continuous basis, that the firm could potentially acquire external knowledge through the outsourcing of $\mathrm{R} \% \mathrm{D}$ or $\mathrm{R} \& \mathrm{D}$ cooperation. If a firm introduces a process innovation, innovation expenditures are attributed to a certain extent to process innovations. This is why a dummy variable controls for the introduction of process innovations.

The model includes also the explanatory variables from the first stage, with the exception of a firm's degree of product diversity and its market share (which serve as exclusion restriction) and the dummy variable, indicating that the firm has at least one registered trademark in 2007.

\subsubsection{Impact of Brand Use on Innovation}

Table 3.3 presents the full maximum likelihood estimates of the above described Heckman model. Since this study makes use of cross sectional data, the results should be interpreted as associations rather than causal effects. The specification is gradually enriched by including marketing and brand use. Columns (1), (3), (5), (7) present results on the total amount of innovative sales for the second stage of the estimation procedure. Columns (2), (4), (6), (8) report the corresponding first stage results of the selection equation.

Column (1) and (2) present the estimates of the basic specification using common innovation related variables but without including any brand or marketing related ones. The results of the selection equation, presented in Column (2), confirm prior findings from the literature. The propensity to introduce a product innovation increases with firm size, a firm's technological capabilities, captured through its patent stock and the proportion of high skilled labour. Furthermore, results show that older firms are less likely to introduce innovations than younger ones and the more diverse the product portfolio of a firm, the more likely is the introduction of a product innovation. Firms with a larger market share innovate more and firms operating in an industry with quickly outdated products and services are also more likely to introduce product innovations. The differences in the propensity to innovate are also jointly significant across industries. 
Table 3.3: The Propensity to Innovate and Determinants of Innovation Performance

\begin{tabular}{|c|c|c|c|c|c|c|c|c|}
\hline & $\begin{array}{c}(1) \\
\text { Sales }\end{array}$ & $\begin{array}{c}(2) \\
\text { yes/no }\end{array}$ & $\begin{array}{c}(3) \\
\text { Sales }\end{array}$ & $\begin{array}{c}(4) \\
\text { yes/no }\end{array}$ & $\begin{array}{c}(5) \\
\text { Sales }\end{array}$ & $\begin{array}{c}(6) \\
\text { yes/no }\end{array}$ & $\begin{array}{c}(7) \\
\text { Sales }\end{array}$ & $\begin{array}{c}(8) \\
\text { yes/no }\end{array}$ \\
\hline Firm Size (ln \# empl.) & $\begin{array}{l}0.940^{* * *} \\
(0.029)\end{array}$ & $\begin{array}{l}0.067^{* * *} \\
(0.020)\end{array}$ & $\begin{array}{l}0.929 * * * \\
(0.029)\end{array}$ & $\begin{array}{l}0.050^{* *} \\
(0.020)\end{array}$ & $\begin{array}{l}0.929^{* * *} \\
(0.029)\end{array}$ & $\begin{array}{l}0.050^{* *} \\
(0.020)\end{array}$ & $\begin{array}{c}0.932^{* * *} \\
(0.029)\end{array}$ & $\begin{array}{c}0.050^{* *} \\
(0.020)\end{array}$ \\
\hline Productivity (L2) & $\begin{array}{l}0.488^{* * *} \\
(0.052)\end{array}$ & $\begin{array}{c}-0.002 \\
(0.039)\end{array}$ & $\begin{array}{l}0.471^{* * *} \\
(0.051)\end{array}$ & $\begin{array}{c}-0.013 \\
(0.039)\end{array}$ & $\begin{array}{l}0.470^{* * *} \\
(0.051)\end{array}$ & $\begin{array}{c}-0.013 \\
(0.039)\end{array}$ & $\begin{array}{l}0.469^{* * *} \\
(0.051)\end{array}$ & $\begin{array}{c}-0.013 \\
(0.039)\end{array}$ \\
\hline Marketing Intensity & & & $\begin{array}{l}30.358^{\text {*** }} \\
(5.532)\end{array}$ & & $\begin{array}{l}29.387^{\text {**** }} \\
(5.522)\end{array}$ & & $\begin{array}{l}39.941^{* * *} \\
(9.603)\end{array}$ & \\
\hline Brand Use & & & $\begin{array}{l}0.241^{* * *} \\
(0.070)\end{array}$ & & & & & \\
\hline Established Brand (D) & & & & & $\begin{array}{l}0.346^{* * *} \\
(0.075)\end{array}$ & & $\begin{array}{l}0.380^{* * *} \\
(0.079)\end{array}$ & \\
\hline Est. Brand x Market. & & & & & & & $\begin{array}{c}-16.236 \\
(11.517)\end{array}$ & \\
\hline New Brand (D) & & & & & $\begin{array}{c}0.011 \\
(0.095)\end{array}$ & & $\begin{array}{c}0.001 \\
(0.105)\end{array}$ & \\
\hline New Brand x Market. & & & & & & & $\begin{array}{c}1.964 \\
(16.905)\end{array}$ & \\
\hline Trademark (D, L3) & & & & $\begin{array}{l}0.238^{* * *} \\
(0.056)\end{array}$ & & $\begin{array}{l}0.238^{* * *} \\
(0.056)\end{array}$ & & $\begin{array}{l}0.238^{\text {*** }} \\
(0.056)\end{array}$ \\
\hline Innovation Intensity & $\begin{array}{l}4.933^{* * *} \\
(1.344)\end{array}$ & & $\begin{array}{l}3.661^{* * *} \\
(1.338)\end{array}$ & & $\begin{array}{c}3.513^{* * *} \\
(1.334)\end{array}$ & & $\begin{array}{l}3.670^{* * *} \\
(1.347)\end{array}$ & \\
\hline High Skilled Labour & $\begin{array}{l}0.006^{* * *} \\
(0.002)\end{array}$ & $\begin{array}{l}0.009 * * * \\
(0.001)\end{array}$ & $\begin{array}{l}0.005^{* * *} \\
(0.002)\end{array}$ & $\begin{array}{l}0.008^{* * * *} \\
(0.001)\end{array}$ & $\begin{array}{l}0.005^{* * *} \\
(0.002)\end{array}$ & $\begin{array}{l}0.008^{* * *} \\
(0.001)\end{array}$ & $\begin{array}{c}0.005^{* * *} \\
(0.002)\end{array}$ & $\begin{array}{l}0.008^{* * *} \\
(0.001)\end{array}$ \\
\hline Process Innovation (D) & $\begin{array}{l}0.178^{* * *} \\
(0.066)\end{array}$ & & $\begin{array}{l}0.176^{\text {*** }} \\
(0.065)\end{array}$ & & $\begin{array}{l}0.173^{* * *} \\
(0.064)\end{array}$ & & $\begin{array}{l}0.176^{* * *} \\
(0.064)\end{array}$ & \\
\hline Patent Stock (ln, L1) & $\begin{array}{l}0.089^{* *} \\
(0.040)\end{array}$ & $\begin{array}{l}0.178^{* * *} \\
(0.042)\end{array}$ & $\begin{array}{c}0.072^{*} \\
(0.039)\end{array}$ & $\begin{array}{l}0.174^{* * *} \\
(0.042)\end{array}$ & $\begin{array}{c}0.067^{*} \\
(0.039)\end{array}$ & $\begin{array}{l}0.174^{* * *} \\
(0.042)\end{array}$ & $\begin{array}{r}0.066^{*} \\
(0.039)\end{array}$ & $\begin{array}{l}0.174^{* * *} \\
(0.042)\end{array}$ \\
\hline Continuous R\&D (D) & $\begin{array}{c}0.096 \\
(0.076)\end{array}$ & & $\begin{array}{c}0.106 \\
(0.075)\end{array}$ & & $\begin{array}{c}0.111 \\
(0.075)\end{array}$ & & $\begin{array}{c}0.105 \\
(0.075)\end{array}$ & \\
\hline External R\&D (D) & $\begin{array}{c}0.045 \\
(0.076)\end{array}$ & & $\begin{array}{c}0.032 \\
(0.075)\end{array}$ & & $\begin{array}{c}0.028 \\
(0.075)\end{array}$ & & $\begin{array}{c}0.028 \\
(0.075)\end{array}$ & \\
\hline Cooperation (D) & $\begin{array}{c}-0.008 \\
(0.075)\end{array}$ & & $\begin{array}{c}-0.012 \\
(0.074)\end{array}$ & & $\begin{array}{c}-0.004 \\
(0.074)\end{array}$ & & $\begin{array}{c}-0.000 \\
(0.074)\end{array}$ & \\
\hline Exporter (D) & $\begin{array}{l}0.301^{* * *} \\
(0.093)\end{array}$ & $\begin{array}{l}0.453^{* * *} \\
(0.055)\end{array}$ & $\begin{array}{l}0.250^{* * *} \\
(0.092)\end{array}$ & $\begin{array}{l}0.427^{* * *} \\
(0.055)\end{array}$ & $\begin{array}{l}0.252^{* * *} \\
(0.091)\end{array}$ & $\begin{array}{l}0.427^{* * *} \\
(0.055)\end{array}$ & $\begin{array}{c}0.250^{* * *} \\
(0.091)\end{array}$ & $\begin{array}{l}0.427^{\text {*** }} \\
(0.055)\end{array}$ \\
\hline Firm Age & $\begin{array}{l}-0.140^{* * *} \\
(0.043)\end{array}$ & $\begin{array}{c}-0.135^{* * *} \\
(0.030)\end{array}$ & $\begin{array}{l}-0.136^{* * *} \\
(0.042)\end{array}$ & $\begin{array}{c}-0.142^{* * *} \\
(0.030)\end{array}$ & $\begin{array}{c}-0.136^{* * *} \\
(0.042)\end{array}$ & $\begin{array}{c}-0.142^{* * *} \\
(0.030)\end{array}$ & $\begin{array}{c}*-0.135^{* * * *} \\
(0.042)\end{array}$ & $\begin{array}{c}-0.142^{* * *} \\
(0.030)\end{array}$ \\
\hline Quickly Outdated & $\begin{array}{c}0.592 \\
(0.569)\end{array}$ & $\begin{array}{c}0.977^{* *} \\
(0.422)\end{array}$ & $\begin{array}{c}0.399 \\
(0.560)\end{array}$ & $\begin{array}{c}0.926^{* *} \\
(0.422)\end{array}$ & $\begin{array}{c}0.341 \\
(0.559)\end{array}$ & $\begin{array}{l}0.925^{* *} \\
(0.422)\end{array}$ & $\begin{array}{c}0.393 \\
(0.560)\end{array}$ & $\begin{array}{l}0.925^{* *} \\
(0.422)\end{array}$ \\
\hline Group (D) & $\begin{array}{l}0.196^{* *} \\
(0.080)\end{array}$ & $\begin{array}{c}-0.045 \\
(0.058)\end{array}$ & $\begin{array}{l}0.156^{* *} \\
(0.079)\end{array}$ & $\begin{array}{c}-0.049 \\
(0.058)\end{array}$ & $\begin{array}{l}0.154^{* *} \\
(0.078)\end{array}$ & $\begin{array}{c}-0.049 \\
(0.058)\end{array}$ & $\begin{array}{c}0.149^{*} \\
(0.078)\end{array}$ & $\begin{array}{c}-0.049 \\
(0.058)\end{array}$ \\
\hline East Germany (D) & $\begin{array}{l}-0.164^{* *} \\
(0.072)\end{array}$ & $\begin{array}{c}0.028 \\
(0.050)\end{array}$ & $\begin{array}{c}-0.129 * \\
(0.071)\end{array}$ & $\begin{array}{c}0.041 \\
(0.051)\end{array}$ & $\begin{array}{c}-0.125^{*} \\
(0.071)\end{array}$ & $\begin{array}{c}0.041 \\
(0.051)\end{array}$ & $\begin{array}{c}-0.121^{*} \\
(0.071)\end{array}$ & $\begin{array}{c}0.041 \\
(0.051)\end{array}$ \\
\hline Diversity $(\ln )$ & & $\begin{array}{l}0.179^{* * *} \\
(0.053)\end{array}$ & & $\begin{array}{l}0.174^{* * *} \\
(0.053)\end{array}$ & & $\begin{array}{l}0.174^{* * *} \\
(0.053)\end{array}$ & & $\begin{array}{l}0.174^{* * *} \\
(0.053)\end{array}$ \\
\hline Market Share (ln, L2) & & $\begin{array}{l}0.026^{* * *} \\
(0.006)\end{array}$ & & $\begin{array}{l}0.024^{* * *} \\
(0.006)\end{array}$ & & $\begin{array}{l}0.024^{\text {**** }} \\
(0.006)\end{array}$ & & $\begin{array}{l}0.024^{* * *} \\
(0.006)\end{array}$ \\
\hline W_In & 0.00 & & 0.00 & & 0.000 & & 0.000 & \\
\hline Lambda & 0.126 & & 0.129 & & 0.124 & & 0.129 & \\
\hline Chi2 (LR test $\rho=0$ ) & 2587.762 & & 705.537 & & 733.620 & & 739.943 & \\
\hline P-Value $(\rho=0)$ & 0.000 & & 0.000 & & 0.000 & & 0.000 & \\
\hline No. of Innovators & 1,461 & & 1,461 & & 1,461 & & 1,461 & \\
\hline Observations & 3,933 & & 3,933 & & 3,933 & & 3,933 & \\
\hline
\end{tabular}

Notes: The regression additionally includes a dummy variable indicating patent stock is zero. (D) denotes dummy variables. (L1) denotes one, (L2) two, and (L3) three year lagged variables, which refer to the year 2009, 2008, and 2007.

Source: ZEW: Mannheim Innovation Panel, survey 2011.

Given that the firm has introduced a product innovation, the commercial success with these innovations is investigated in the second stage. Column (1) of Table 3.3 shows the result for innovative sales. Not surprisingly, it turns out that larger as 
well as more productive firms are associated with higher innovation performance. With respect to the control variables, the results show, as could be expected, that the higher the innovation intensity, the higher a firm's innovation performance in terms of innovative sales. The same is true for the share of high skilled labour, which captures another important input factor for a firm's innovation activities. The introduction of a process innovation adds to the innovation performance and the patent stock shows also significantly positive effects. Surprisingly, the fact that a firm conducts $R \& D$ on a continuous basis or acquires external knowledge through external $R \& D$ or $R \& D$ cooperation show no significant impact. These indicators might have an influence in the earlier stage of the research and development process, but not in the commercialisation of product innovations. Firms that operate in foreign markets achieve higher sales with innovations, while firms that operate in markets where products and services are quickly outdated do not yield higher innovation success.

The results of main interest concern a firm's choice to introduce innovations under brand names onto the market. The specification presented in Column (3) includes additionally brand use as well as marketing intensity. The results show that the use of a brand has a highly significant impact on innovation performance. The market introduction of a product innovation is associated with about $24 \%$ higher sales if the firm uses a brand. Marketing intensity improves also the commercial success with product innovations. The highly significant coefficient of marketing intensity is furthermore several times higher than the coefficient for innovation intensity. Considering marketing and brand use leads to considerably smaller coefficients of innovation intensity, while the coefficient of the patent stock is also smaller and shows only slightly significant effects.

Another striking result with respect to our research question is that the probability of introducing a product innovation is associated with a firm's brand strategy. Whether a firm pursues a brand strategy is captured through a dummy variable indicating at least one registered trademark in 2007. Column (4) shows that firms which have invested in brand protection through trademark registrations in the past, are more likely to introduce further product innovations in the future.

Brand use can be distinguished between the use of an established brand or the use of a new brand to introduce product innovations onto the market. Column 5 presents the estimates of the specification that makes this distinction. The market introduction under an established brand shows a highly significant impact on innovation performance. This underlines the potential of an established brand to achieve awareness, the perception of desirable overall quality, and favorable associations to promote new products (Keller and Lehmann, 2006). An established brand is in this respect an important asset that is associated with about $35 \%$ larger sales with product innovations and constitutes an important competitive advantage.

Our results show on the contrary that product innovators that use a new brand for 
market introduction do not outperform product innovators that do not use brands for product innovation in the first three years after market introduction. Admittedly, we do not know the exact year of market introduction within the three-year period. Thus for some firms we probably measure the effect within a shorter period after market introduction. It is not surprising that the use of a new brand shows no significant association to innovation performance, since the impact from a brand arises from its degree of awareness and favourable associations of the target audience with the brand. The creation of brand awareness and positive associations takes time and an immediate impact on innovation performance cannot be taken for granted. One advantage of the use of established brands to introduce new products are lower marketing costs. A new brand, on the contrary, has to be established in the market, which might be associated with higher marketing costs. The specification in Column 7 thus includes additionally interaction terms between the use of an established brand and marketing intensity as well as between the use of a new brand and marketing intensity. Both interaction terms are not significant. I prefer therefore the specification presented in Column (5), which includes marketing intensity and distinguishes between established and new brands, but does not consider any interaction terms.

\subsubsection{Impact of Brand Use by Degree of Innovation}

Product innovations can be distinguished between those that are new-to-the-market and those that are not. If a product innovation is not new-to-the-market, but newto-the-firm, it is considered as an imitative product innovation. The impact of the use of a brand on the performance of a product innovation might differ between these two categories of innovativeness. Columns (1), (3), (5) of Table 3.4 present results for the second stage using total amount of innovative sales, sales with market novelties and sales with imitative products. Columns (2), (4), (6) report the corresponding first stage results (selection equation).

The results of the selection equation are quite similar for all three models and confirm prior findings from the literature. The propensity to introduce a product innovation, a market novelty or an imitative innovation increases with firm size, a firm's technological capabilities, captured through its patent stock and the proportion of high skilled labour. Furthermore, results show that older firms are less likely to introduce innovations than younger ones and the more diverse the product portfolio of a firm, the more likely is the introduction of a product innovation or imitative innovation, but surprisingly not of market novelties. Firms with a larger market share innovate more and firms operating in an industry with quickly outdated products and services are also more likely to introduce product innovations and market novelties. The differences in the propensity to innovate are also jointly significant across industries. 
Table 3.4: The Propensity to Innovate and Determinants of Innovation Performance

\begin{tabular}{|c|c|c|c|c|c|c|}
\hline & \multicolumn{2}{|c|}{ Innovation } & \multicolumn{2}{|c|}{ Market Novelty } & \multicolumn{2}{|c|}{ Imitation } \\
\hline & $(1)$ & $(2)$ & $(3)$ & (4) & $(5)$ & $(6)$ \\
\hline & Sales & yes or no & Sales & yes or no & Sales & yes or no \\
\hline & 2nd stage & 1st stage & 2nd stage & 1st stage & 2nd stage & 1st stage \\
\hline \multirow[t]{2}{*}{ Firm Size $(\ln )$} & $0.929^{* * *}$ & $0.050 * *$ & $0.755^{* * *}$ & 0.035 & $0.966^{* * *}$ & $0.061^{* * *}$ \\
\hline & $(0.029)$ & $(0.020)$ & $(0.064)$ & $(0.022)$ & $(0.032)$ & $(0.020)$ \\
\hline \multirow[t]{2}{*}{ Productivity (L2) } & $0.470^{* * *}$ & -0.013 & $0.335^{* * *}$ & $0.134^{* *}$ & $0.412^{* * *}$ & 0.004 \\
\hline & $(0.051)$ & $(0.039)$ & $(0.108)$ & $(0.053)$ & $(0.052)$ & $(0.039)$ \\
\hline \multirow[t]{2}{*}{ Marketing Intensity } & $29.387^{* * *}$ & & $32.033^{* * *}$ & & $26.874^{* * *}$ & \\
\hline & $(5.522)$ & & $(10.434)$ & & $(5.978)$ & \\
\hline \multirow[t]{2}{*}{ Established Brand (D) } & $0.346^{* * *}$ & & 0.148 & & $0.327^{* * *}$ & \\
\hline & $(0.075)$ & & $(0.120)$ & & $(0.082)$ & \\
\hline \multirow[t]{2}{*}{ New Brand (D) } & 0.011 & & -0.200 & & -0.010 & \\
\hline & $(0.095)$ & & $(0.142)$ & & $(0.107)$ & \\
\hline \multirow[t]{2}{*}{ Trademark (D, L3) } & & $0.238^{* * *}$ & & $0.184^{* * *}$ & & $0.159^{* * *}$ \\
\hline & & $(0.056)$ & & $(0.043)$ & & $(0.056)$ \\
\hline \multirow{2}{*}{ Innovation Intensity } & $3.513^{* * *}$ & & $6.233^{* *}$ & & 2.150 & \\
\hline & $(1.334)^{*}$ & & $(2.495)$ & & $(1.398)$ & \\
\hline \multirow[t]{2}{*}{ High Skilled Labour } & $0.005^{* * *}$ & $0.008^{* * *}$ & $-0.009^{* *}$ & $0.007^{* * *}$ & $0.006^{* * *}$ & $0.006^{* * *}$ \\
\hline & $(0.002)$ & $(0.001)$ & $(0.004)$ & $(0.001)$ & $(0.002)$ & $(0.001)$ \\
\hline \multirow[t]{2}{*}{ Process Innovation (D) } & $0.173^{* * *}$ & & $0.224^{* *}$ & & 0.082 & \\
\hline & $(0.064)$ & & $(0.109)$ & & $(0.070)$ & \\
\hline \multirow[t]{2}{*}{ Patent Stock (ln, L1) } & $0.067^{*}$ & $0.174^{* * *}$ & -0.122 & $0.103^{* * *}$ & $0.070^{*}$ & $0.125^{* * *}$ \\
\hline & $(0.039)$ & $(0.042)$ & $(0.089)$ & $(0.034)$ & $(0.042)$ & $(0.037)$ \\
\hline \multirow[t]{2}{*}{ Continuous R\&D (D) } & 0.111 & & -0.029 & & 0.058 & \\
\hline & $(0.075)$ & & $(0.123)$ & & $(0.083)$ & \\
\hline \multirow[t]{2}{*}{ External R\&D (D) } & 0.028 & & -0.033 & & 0.091 & \\
\hline & $(0.075)$ & & $(0.122)$ & & $(0.082)$ & \\
\hline \multirow[t]{2}{*}{ Cooperation (D) } & -0.004 & & 0.093 & & $-0.159^{* *}$ & \\
\hline & $(0.074)$ & & $(0.123)$ & & $(0.080)$ & \\
\hline \multirow[t]{2}{*}{ Exporter (D) } & $0.252^{* * *}$ & $0.427 * * *$ & $-0.910^{* * *}$ & $0.476 * * *$ & $0.318^{* * *}$ & $0.333^{* * *}$ \\
\hline & $(0.091)$ & $(0.055)$ & $(0.199)$ & $(0.065)$ & $(0.098)$ & $(0.056)$ \\
\hline \multirow[t]{2}{*}{ Firm Age } & $-0.136^{* * *}$ & $-0.142^{* * *}$ & 0.069 & $-0.125^{* * *}$ & $-0.097^{* *}$ & $-0.122^{* * *}$ \\
\hline & $(0.042)$ & $(0.030)$ & $(0.098)$ & $(0.034)$ & $(0.047)$ & $(0.030)$ \\
\hline \multirow[t]{2}{*}{ Quickly Outdated } & 0.341 & $0.925^{* *}$ & -2.174 & $1.315^{* * *}$ & 0.570 & 0.647 \\
\hline & $(0.559)$ & $(0.422)$ & $(1.344)$ & $(0.483)$ & $(0.596)$ & $(0.420)$ \\
\hline \multirow{2}{*}{ Group (D) } & $0.154^{* *}$ & -0.049 & -0.101 & 0.051 & $0.225^{* * *}$ & -0.066 \\
\hline & $(0.078)$ & $(0.058)$ & $(0.182)$ & $(0.064)$ & $(0.087)$ & $(0.058)$ \\
\hline East Germany (D) & $-0.125^{*}$ & 0.041 & -0.091 & -0.039 & -0.099 & $0.112^{* *}$ \\
\hline & $(0.071)$ & $(0.051)$ & $(0.166)$ & $(0.058)$ & $(0.078)$ & $(0.051)$ \\
\hline Diversity $(\ln )$ & & $0.174^{* * *}$ & & -0.038 & & $0.217^{* * *}$ \\
\hline & & $(0.053)$ & & $(0.044)$ & & $(0.052)$ \\
\hline Market Share (ln, L2) & & $0.024^{* * *}$ & & $0.022^{* * *}$ & & $0.018^{* * *}$ \\
\hline & & $(0.006)$ & & $(0.005)$ & & $(0.006)$ \\
\hline W_Industry (p-value) & 0.000 & & 0.000 & & 0.000 & \\
\hline Lambda & 0.124 & & -2.473 & & 0.259 & \\
\hline Chi2 (LR test for $\rho=0)$ & 2733.620 & & 426.150 & & 2420.577 & \\
\hline P-Value $(\rho=0)$ & 0.000 & & 0.000 & & 0.000 & \\
\hline No. of Innovators & 1,461 & & 715 & & 1,246 & \\
\hline Observations & 3,933 & & 3,933 & & 3,933 & \\
\hline
\end{tabular}

Notes: The regression additionally includes a dummy variable indicating patent stock is zero. (D) denotes dummy variables. (L2) denotes two, and (L3) three year lagged variables.

Source: ZEW: Mannheim Innovation Panel, survey 2011.

Table 3.4 shows in Column (3) the impact of brand use on the performance of market novelties. Like for product innovations, the use of a new brand has no significant effect. However, in contrast to prior findings, established brands show 
no significant impact for market novelties anymore. This might be explained by the higher level of uncertainty that market novelties have. It might also be the case that the reduced sample (only about half of the product innovators introduce market novelties) is too small, to obtain a significant effect. Even if the reduced sample size increases standard errors, we also observe the coefficient to be much smaller than in Column (1). Thus, the results indicate that the reputation of a firm's established brand is not easily transferable to market novelties.

Turning to imitative innovations in Column (3), the use of a new brand has still no significant effect, but the use of an established brand has a highly significant impact on the market performance of imitative product innovations and is associated with $32 \%$ larger sales with imitative products.

\subsubsection{Impact of Brand Use by Firm Size}

The impact of brands might differ between smaller and larger firms. Larger firms might be able to establish a brand in the market more easily because of greater financial resources and better distribution channels. In order to see whether size matters for the impact of brand use, the sample is split at the median number of employees (31 employees) to investigate differences between smaller and larger firms. The split sample analysis shows that the estimates for the impact of brands on the performance of product innovations as well as on the performance with imitative products do not differ much between smaller and larger firms (see Table 3.9 in the Appendix). The use of an established brand is always associated with about $34 \%$ to $39 \%$ larger sales.

The differences are more striking for the performance with market novelties (see Table 3.5). The introduction of a market novelty under an established brand has no significant impact in the full sample, as well as in the sub-sample of larger firms, but has a significantly positive impact for the sample of smaller firms. As mentioned, one might expect the effect of established brands on the success of market novelties to be larger for large firms. However, and most strikingly, we find no impact of established brand on innovation success with new-to-market product for large firms. It is only in smaller firms, where we find a positive relationship. Smaller firms achieve with respect to these results about 39\% larger sales with market novelties, provided that the market novelty is introduced under an established brand.

Furthermore, the introduction under a new brand is significantly negatively associated with the performance of market novelties for smaller firms. A smaller firm achieves about $53 \%$ less sales with market novelties. This points to the fact that the creation of a brand takes time and shows that at least in the short-run negative performance effects are possible.

Another interesting finding is that marketing activities significantly enhance performance only for larger firms. Innovation intensity and skilled labour associated with 
Table 3.5: Split Sample: Differences Between Small and Larger Firms

\begin{tabular}{|c|c|c|c|c|}
\hline & \multicolumn{4}{|c|}{ Market Novelty } \\
\hline & \multicolumn{2}{|c|}{$<$ Median Size } & \multicolumn{2}{|c|}{$\geq$ Median Size } \\
\hline & $\begin{array}{c}\text { Sales } \\
\text { 2nd stage }\end{array}$ & $\begin{array}{l}\text { yes or no } \\
\text { 1st stage }\end{array}$ & $\begin{array}{c}\text { Sales } \\
\text { 2nd stage }\end{array}$ & $\begin{array}{l}\text { yes or no } \\
1 \text { st stage }\end{array}$ \\
\hline Firm Size (ln \# of employees) & $\begin{array}{l}0.623^{* * *} \\
(0.178)\end{array}$ & $\begin{array}{l}0.155^{* *} \\
(0.078)\end{array}$ & $\begin{array}{l}0.780^{* * * *} \\
(0.091)\end{array}$ & $\begin{array}{c}0.039 \\
(0.038)\end{array}$ \\
\hline Productivity (L2) & $\begin{array}{l}3.238^{* * *} \\
(0.487)\end{array}$ & $\begin{array}{l}-0.053 \\
(0.143)\end{array}$ & $\begin{array}{l}0.286^{* * * *} \\
(0.084)\end{array}$ & $\begin{array}{l}0.046 \\
(0.048)\end{array}$ \\
\hline Marketing Intensity & $\begin{array}{l}18.825 \\
(18.525)\end{array}$ & & $\begin{array}{l}21.674^{* *} \\
(10.361)\end{array}$ & \\
\hline Established Brand (D) & $\begin{array}{c}0.394^{* *} \\
(0.197)\end{array}$ & & $\begin{array}{c}0.029 \\
(0.187)\end{array}$ & \\
\hline New Brand (D) & $\begin{array}{l}-0.533^{* *} \\
(0.248)\end{array}$ & & $\begin{array}{c}-0.193 \\
(0.206)\end{array}$ & \\
\hline Trademark (D, L3) & & $\begin{array}{l}0.348^{* * *} \\
(0.104)\end{array}$ & & $\begin{array}{l}0.229^{* * *} \\
(0.079)\end{array}$ \\
\hline Innovation Intensity & $\begin{array}{c}0.635 \\
(2.235)\end{array}$ & & $\begin{array}{c}6.507^{*} \\
(3.722)\end{array}$ & \\
\hline High Skilled Labour & $\begin{array}{l}-0.006 \\
(0.004)\end{array}$ & $\begin{array}{l}0.006^{* * *} \\
(0.002)\end{array}$ & $\begin{array}{l}0.021^{* * *} \\
(0.006)\end{array}$ & $\begin{array}{l}0.008^{* * *} \\
(0.002)\end{array}$ \\
\hline Process Innovation (D) & $\begin{array}{c}0.052 \\
(0.172)\end{array}$ & & $\begin{array}{c}0.163 \\
(0.177)\end{array}$ & \\
\hline Patent Stock (ln, L1) & $\begin{array}{c}0.247 \\
(0.218)\end{array}$ & $\begin{array}{l}-0.113 \\
(0.138)\end{array}$ & $\begin{array}{c}0.078 \\
(0.101)\end{array}$ & $\begin{array}{l}0.167^{* * *} \\
(0.040)\end{array}$ \\
\hline Continuous R\&D (D) & $\begin{array}{c}-0.059 \\
(0.202)\end{array}$ & & $\begin{array}{c}0.093 \\
(0.210)\end{array}$ & \\
\hline External R\&D (D) & $\begin{array}{l}-0.095 \\
(0.202)\end{array}$ & & $\begin{array}{c}0.058 \\
(0.191)\end{array}$ & \\
\hline Cooperation (D) & $\begin{array}{c}0.173 \\
(0.189)\end{array}$ & & $\begin{array}{l}-0.209 \\
(0.200)\end{array}$ & \\
\hline Exporter (D) & $\begin{array}{l}-0.303 \\
(0.259)\end{array}$ & $\begin{array}{l}0.453^{* * *} \\
(0.093)\end{array}$ & $\begin{array}{c}-0.076 \\
(0.360)\end{array}$ & $\begin{array}{l}0.424^{* * *} \\
(0.102)\end{array}$ \\
\hline Firm Age & $\begin{array}{c}-0.182 \\
(0.147)\end{array}$ & $\begin{array}{l}-0.244^{* * *} \\
(0.059)\end{array}$ & $\begin{array}{c}-0.091 \\
(0.114)\end{array}$ & $\begin{array}{c}-0.088^{*} \\
(0.046)\end{array}$ \\
\hline Quickly Outdated & $\begin{array}{l}-1.102 \\
(1.588)\end{array}$ & $\begin{array}{l}2.674^{* * *} \\
(0.742)\end{array}$ & $\begin{array}{c}0.458 \\
(1.620)\end{array}$ & $\begin{array}{c}0.215 \\
(0.704)\end{array}$ \\
\hline Group (D) & $\begin{array}{l}-0.455^{*} \\
(0.252)\end{array}$ & $\begin{array}{c}0.119 \\
(0.124)\end{array}$ & $\begin{array}{l}-0.055 \\
(0.196)\end{array}$ & $\begin{array}{c}0.001 \\
(0.080)\end{array}$ \\
\hline East Germany (D) & $\begin{array}{c}-0.167 \\
(0.179)\end{array}$ & $\begin{array}{l}-0.029 \\
(0.085)\end{array}$ & $\begin{array}{c}-0.066 \\
(0.220)\end{array}$ & $\begin{array}{l}-0.046 \\
(0.088)\end{array}$ \\
\hline Diversity (ln) & & $\begin{array}{c}0.049 \\
(0.105)\end{array}$ & & $\begin{array}{l}0.013 \\
(0.077)\end{array}$ \\
\hline Market Share (ln, L2) & & $\begin{array}{l}0.046^{* * *} \\
(0.010)\end{array}$ & & $\begin{array}{l}0.043^{* * *} \\
(0.011) \\
\end{array}$ \\
\hline W_Industry (p-value) & 0.000 & & 0.000 & \\
\hline Lambda & -0.607 & & -0.249 & \\
\hline Chi2 (LR test for $\rho=0)$ & 122.569 & & 226.904 & \\
\hline P-Value $(\rho=0)$ & 0.000 & & 0.000 & \\
\hline No. of Innovators & 622 & & 839 & \\
\hline Observations & 1,955 & & 1,978 & \\
\hline
\end{tabular}

Notes: The regression additionally includes a dummy variable indicating patent stock is zero. (D) denotes dummy variables. (L2) denotes two, and (L3) three year lagged variables. Source: ZEW: Mannheim Innovation Panel, survey 2011. 
significantly higher sales with market novelties in the sample of larger but not in that of smaller firms.

\subsubsection{Robustness Check}

Innovation performance is measured in 'raw values', that is, as sales with product innovations in millions of Euros. The same figure expressed as intensity, namely as share on total sales, is a widely used alternative measure for innovation performance (Crépon et al., 1998; Mairesse and Mohnen, 2002). Using the share of sales with innovations as dependent variable yields results which are properly comparable. The model specification is exactly identical to the base line model to ensure comparability. The introduction of an innovation under a new brand is again not correlated with innovation performance. An established brand, however, has a highly significant impact on the performance with product innovations, imitative innovations, as well as market novelties. The significant effect on market novelties is the most important difference to the base model. Table 3.10 in the Appendix provides the results in full detail.

\subsection{Concluding Remarks}

A firm has to decide whether it uses brand names to introduce its product innovations into the market place. Branded product innovations have the potential to achieve a higher level of awareness among the target audience, might profit from the reputation of the brand, and allow a firm to better appropriate the returns from its innovations (Aaker, 2007).

This study makes use of the German contribution to the Community Innovation Survey (CIS) to provide empirical evidence on the impact of brands on innovation performance. The 2011 survey wave provides a direct link between the introduction of a firm's product innovations and its use of a new or an established brand. This direct link could not be made through the match of trademark register data, since a firm might use an established but not trademark protected brand or it might have trademark protected brands but decides not to use them for the market introduction of the particular product innovation. The descriptive analysis shows that about $38 \%$ of product innovating firms introduce new products under a brand. About $26.5 \%$ of the firms rely on already established brands, while $14 \%$ introduce product innovations under a new brand name.

The question is whether firms are more successful with product innovations if they decide to use brands. The results suggest that branded product innovations are more successful in terms of sales with these new products. The use of an established brand is associated to remarkable $35 \%$ higher sales with product innovations. The market introduction of a product innovation under a new brand shows no significant 
effect. The empirical results could be driven by the unobservable quality of the firm's innovation, so that this can not be interpreted as causal effects.

Smaller and larger firms differ with respect to the impact of brands on the performance of market novelties. The sub-sample of smaller firms shows a significantly positive effect of the use of established brands. The use of an established brand by smaller firms is associated with about $30 \%$ larger sales with market novelties. The introduction of a market novelty by smaller firms under a new brand is however associated with significantly reduced sales of about $53 \%$.

It takes time to built a new brand. The empirical evidence provided by (Crass et al., 2014, see chapter 4) shows a positive impact of brands on overall firm performance after about four years. A positive impact of the introduction of product innovations under a new brand on innovation performance might also take time. The innovation performance is defined as a firm's sales with innovations that have been introduced into the market during the three year period 2008 to 2010. Innovation performance is directly linked to a firm's product innovation, but it captures only the immediate success. Whether product innovations are also successful in the long-run is not observable. Future research should investigate the long-run impact of the use of new and established brands on innovation performance. 


\section{A Appendix}

\section{A.1 Definition of Variables}

Table 3.6: Definitions of Main Variables

\begin{tabular}{ll}
\hline Variable & Definition \\
\hline Product Innovation (D) & $\begin{array}{l}\text { Dummy variable taking value 1, if firm introduced a product } \\
\text { innovation during the period from } 2008 \text { to } 2010 .\end{array}$ \\
Sales with Product Innova- & $\begin{array}{l}\text { Sales with product innovations; computed as share of sales with } \\
\text { product innovations } x \text { sales in million Euros. }\end{array}$ \\
tions & Share of sales with product innovations in 2010. \\
Sales Share Innovations & $\begin{array}{l}\text { Dummy variable taking value 1, if firm introduced a new-to-the } \\
\text { Market Novelty (D) } \\
\text { prior to any competitor ("market novelty") during the period } \\
\text { from 2008 to 2010. }\end{array}$
\end{tabular}

Sales Share Market Novel- Share of sales with market novelties in 2010. ties $(\%)$

Sales Market Novelties

Sales with market novelties; computed as share of sales with market novelties $x$ sales in million Euros.

Imitation Product (D)

Dummy variable taking value 1 , if firm introduced an imitative product innovation during the period from 2008 to 2010 .

Sales Share Imitative Innovations $(\%)$

Sales Imitative Innovations

Share of sales with imitative innovations; computed as the difference between the share of sales with product innovations and the share of sales with market novelties.

Sales with imitative innovations in 2010; computed as share of sales with imitative innovations $x$ sales in million Euros.

Marketing Intensity

Marketing expenditures per employee. Includes all internal and external expenditures for advertisement, reputation building, for the conceptual design of marketing strategies, market and costumer research, and the installation of new distribution channels. Pure selling costs are not considered as marketing expenditures.

Established Brand (D) Dummy variable taking value 1, if firm uses an established brand to introduce a product innovation into the market.

New Brand (D)

Dummy variable taking value 1 , if firm uses a new brand to introduce a product innovation into the market.

Trademark (D, L3) Dummy variable indicating firm has at least one registered trademark in 2007. 
Table 3.7: Variable Definitions (continued)

\begin{tabular}{|c|c|}
\hline Variable & Definition \\
\hline Innovation Intensity & $\begin{array}{l}\text { Innovation expenditures per employee. Includes all internal } R \& D \\
\text { and external } R \& D(R \& D \text { contracted out to third parties), ex- } \\
\text { penses for design, licenses and other external knowledge, market } \\
\text { introduction, training and product preparation related to inno- } \\
\text { vation. }\end{array}$ \\
\hline High Skilled Labour & Proportion of employees holding an university degree. \\
\hline Process Innovation (D) & $\begin{array}{l}\text { Dummy variable taking value } 1 \text {, if firm introduced a process in- } \\
\text { novation during the previous three years. }\end{array}$ \\
\hline Patent Stock (ln, L1) & $\begin{array}{l}\text { The log of the lagged stock of patents is built up using the per- } \\
\text { petual inventory method with a constant depreciation rate of } \\
15 \% \text {. }\end{array}$ \\
\hline Patent Stock: zero & Dummy variable indicating firm has no patents. \\
\hline Continuous R\&D (D) & $\begin{array}{l}\text { Dummy variable taking value } 1 \text {, if firm reports to have continuous } \\
\text { internal R\&D activities during } 2008-2010 \text {. }\end{array}$ \\
\hline External R\&D (D) & $\begin{array}{l}\text { Dummy variable indicating firm has contracted out R\&D activi- } \\
\text { ties to third parties. }\end{array}$ \\
\hline Cooperation (D) & $\begin{array}{l}\text { Dummy variable taking value } 1 \text {, if firm reports to have innova- } \\
\text { tion/research alliances. }\end{array}$ \\
\hline Diversity (ln) & $\begin{array}{l}\text { The inverse of the share on total sales of the most important } \\
\text { product in logs. }\end{array}$ \\
\hline Market Share (ln, L2) & Market share with the most important product in 2008 in logs. \\
\hline Firm Size & Log of the number of employees in 2010. \\
\hline Productivity (L2) & Labour productivity: Sales per employee in 2008. \\
\hline Exporter $(\mathrm{D})$ & $\begin{array}{l}\text { Dummy variable taking value } 1 \text {, if firm reports a positive export } \\
\text { value. }\end{array}$ \\
\hline Firm Age & Log of the number of years since the enterprise was founded. \\
\hline Quickly Outdated & $\begin{array}{l}\text { Industry average of the dummy variable taking value } 1 \text {, if firm } \\
\text { reports its products to be quickly outdated. }\end{array}$ \\
\hline Group (D) & $\begin{array}{l}\text { Dummy variable taking value } 1 \text {, if firm reports to be part of an } \\
\text { enterprise group. }\end{array}$ \\
\hline East Germany (D) & $\begin{array}{l}\text { Dummy variable taking value } 1 \text {, if firm is located in East Ger- } \\
\text { many. }\end{array}$ \\
\hline
\end{tabular}




\section{A.2 Descriptive Statistics}

Table 3.8: Descriptive Statistics of Main Variables

\begin{tabular}{lrrrr}
\hline & Mean & \multicolumn{1}{c}{ SD } & Min & Max \\
\hline Product Innovation (D) & 0.371 & 0.483 & 0.00 & 1.00 \\
Sales Share Innovations (\%) & 9.992 & 20.182 & 0.00 & 100.00 \\
Sales with Product Innovations & 6.406 & 77.495 & 0.00 & 2430.00 \\
Market Novelty (D) & 0.182 & 0.386 & 0.00 & 1.00 \\
Sales Share Market Novelties (\%) & 2.810 & 10.195 & 0.00 & 100.00 \\
Sales with Market Novelties & 1.400 & 14.242 & 0.00 & 453.81 \\
Imitation Product (D) & 0.317 & 0.465 & 0.00 & 1.00 \\
Sales Share Imitative Innovations (\%) & 7.182 & 16.529 & 0.00 & 100.00 \\
Sales with Product Imitations & 5.006 & 70.132 & 0.00 & 2255.80 \\
Innovation Intensity & 0.005 & 0.024 & 0.00 & 1.06 \\
High Skilled Labour (\%) & 18.344 & 23.587 & 0.00 & 100.00 \\
Process Innovation (D) & 0.286 & 0.452 & 0.00 & 1.00 \\
Patent Stock (ln, L1) & 0.002 & 0.632 & -4.55 & 8.04 \\
Patent Stock: zero & 0.883 & 0.322 & 0.00 & 1.00 \\
Continuous R\&D (D) & 0.213 & 0.410 & 0.00 & 1.00 \\
External R\&D (D) & 0.149 & 0.356 & 0.00 & 1.00 \\
Cooperation (D) & 0.213 & 0.410 & 0.00 & 1.00 \\
Marketing Intensity & 0.001 & 0.004 & 0.00 & 0.13 \\
Established Brand (D) & 0.099 & 0.299 & 0.00 & 1.00 \\
New Brand (D) & 0.052 & 0.221 & 0.00 & 1.00 \\
Trademark (D, L3) & 0.287 & 0.452 & 0.00 & 1.00 \\
Diversity (ln) & -4.187 & 0.438 & -4.61 & 0.22 \\
Missing: Diversity & 0.068 & 0.251 & 0.00 & 1.00 \\
Market Share (ln, L2) & -0.746 & 4.331 & -6.91 & 4.61 \\
Missing: Market Share (ln, L2) & 0.209 & 0.407 & 0.00 & 1.00 \\
Firm Size (ln \# of employees) & 3.676 & 1.460 & 1.61 & 10.67 \\
Productivity (L2) & 0.203 & 0.555 & 0.00 & 22.74 \\
Exporter (D) & 0.456 & 0.498 & 0.00 & 1.00 \\
Firm Age & 3.146 & 0.843 & 0.69 & 6.19 \\
Quickly Outdated & 0.061 & 0.080 & 0.00 & 0.67 \\
Group (D) & 0.284 & 0.451 & 0.00 & 1.00 \\
East Germany (D) & 0.337 & 0.473 & 0.00 & 1.00 \\
\hline
\end{tabular}

Notes: (D) denotes dummy variables. (L1), (L2), and (L3) denote one, two, and three year lagged variables which refer to the years 2009, 2008, and 2007. All Euro values are expressed in Million.

Source: ZEW: Mannheim Innovation Panel, survey 2011. 
Table 3.9: Split Sample: Differences between smaller and larger firms

\begin{tabular}{|c|c|c|c|c|c|c|c|c|}
\hline & \multicolumn{4}{|c|}{ Innovation } & \multicolumn{4}{|c|}{ Imitation } \\
\hline & \multicolumn{2}{|c|}{$<$ Median Size } & \multicolumn{2}{|c|}{$\geq$ Median Size } & \multicolumn{2}{|c|}{$<$ Median Size } & \multicolumn{2}{|c|}{$\geq$ Median Size } \\
\hline & Sales & yes/no & $\overline{\text { Sales }}$ & yes/no & Sales & yes/no & Sales $\quad$ & yes/no \\
\hline \multirow[t]{2}{*}{ Firm Size (ln \# empl.) } & $0.815^{* * *}$ & * $0.213^{* * *}$ & $1.048^{* * *}$ & 0.052 & $0.953^{* * *}$ & * $0.202^{* * *}$ & $1.086^{* * *}$ & $0.078^{* *}$ \\
\hline & $(0.096)$ & $(0.065)$ & $(0.049)$ & $(0.035)$ & $(0.118)$ & $(0.065)$ & $(0.058)$ & $(0.034)$ \\
\hline \multirow[t]{2}{*}{ Productivity (L2) } & $2.289^{* * *}$ & ${ }^{*}-0.137$ & $0.389^{* * *}$ & 0.002 & $2.004^{* * *}$ & ${ }^{*}-0.151$ & $0.356^{* * *}$ & $=0.020$ \\
\hline & $(0.223)$ & $(0.118)$ & $(0.056)$ & $(0.046)$ & $(0.255)$ & $(0.126)$ & $(0.061)$ & $(0.046)$ \\
\hline \multirow[t]{2}{*}{ Marketing intensity } & $19.183^{*}$ & & $20.719^{* * *}$ & & 9.522 & & $19.910^{* * *}$ & \\
\hline & $(11.589)$ & & $(6.550)$ & & $(12.617)$ & & $(7.082)$ & \\
\hline \multirow[t]{2}{*}{ Established Brand (D) } & $0.392^{* * *}$ & & $0.348^{* * *}$ & & $0.363^{* * *}$ & & $0.336^{* * *}$ & \\
\hline & $(0.107)$ & & $(0.101)$ & & $(0.120)$ & & $(0.109)$ & \\
\hline \multirow[t]{2}{*}{ New Brand (D) } & -0.057 & & 0.034 & & -0.101 & & 0.016 & \\
\hline & $(0.153)$ & & $(0.121)$ & & $(0.183)$ & & $(0.134)$ & \\
\hline \multirow[t]{2}{*}{ Trademark (D, L3) } & & $0.302^{* * *}$ & & $0.207^{* * *}$ & & $0.276^{* * *}$ & & 0.109 \\
\hline & & $(0.096)$ & & $(0.071)$ & & $(0.095)$ & & $(0.071)$ \\
\hline \multirow{2}{*}{ Innovation intensity } & -0.278 & & $8.681^{* * *}$ & & -1.980 & & $7.858^{* * *}$ & \\
\hline & $(1.540)$ & & $(2.261)$ & & $(1.727)$ & & $(2.311)$ & \\
\hline \multirow[t]{2}{*}{ High Skilled Labour } & 0.001 & $0.008^{* * *}$ & $0.012^{* * *}$ & $0.008^{* * *}$ & $* 0.006^{* *}$ & $0.006^{* * *}$ & $0.009^{* * *}$ & $0.005^{* *}$ \\
\hline & $(0.002)$ & $(0.002)$ & $(0.003)$ & $(0.002)$ & $(0.003)$ & $(0.002)$ & $(0.003)$ & $(0.002)$ \\
\hline \multirow[t]{2}{*}{ Process Innovation (D) } & $0.220^{* *}$ & & $0.202^{* *}$ & & $0.192^{* *}$ & & 0.078 & \\
\hline & $(0.086)$ & & $(0.089)$ & & $(0.095)$ & & $(0.097)$ & \\
\hline \multirow[t]{2}{*}{ Patent stock (ln) } & 0.102 & $-0.305^{* *}$ & 0.079 & $0.233^{* * *}$ & $*-0.011$ & -0.203 & 0.088 & $0.159^{* * *}$ \\
\hline & $(0.138)$ & $(0.145)$ & $(0.055)$ & $(0.045)$ & $(0.164)$ & $(0.134)$ & $(0.061)$ & $(0.040)$ \\
\hline \multirow[t]{2}{*}{ Continuous R\&D (D) } & $0.271^{* * *}$ & & 0.030 & & $0.196^{*}$ & & 0.051 & \\
\hline & $(0.103)$ & & $(0.102)$ & & $(0.115)$ & & $(0.113)$ & \\
\hline \multirow[t]{2}{*}{ External R\&D (D) } & 0.115 & & 0.006 & & 0.081 & & 0.123 & \\
\hline & $(0.111)$ & & $(0.096)$ & & $(0.125)$ & & $(0.105)$ & \\
\hline \multirow{2}{*}{ Cooperation (D) } & 0.023 & & -0.037 & & -0.152 & & -0.160 & \\
\hline & $(0.101)$ & & $(0.101)$ & & $(0.111)$ & & $(0.109)$ & \\
\hline Exporter (D) & 0.028 & $0.520^{* * *}$ & $0.489^{* * *}$ & $0.293^{* * *}$ & $* 0.286$ & $0.455^{* * *}$ & $0.518^{* * *}$ & $0.163^{*}$ \\
\hline & $(0.149)$ & $(0.077)$ & $(0.154)$ & $(0.084)$ & $(0.189)$ & $(0.078)$ & $(0.157)$ & $(0.085)$ \\
\hline Firm age & $-0.171^{* *}$ & $-0.198^{* * *}$ & $-0.128^{* *}$ & $-0.100^{* *}$ & $-0.256^{* * *}$ & ${ }^{*}-0.161^{* * *}$ & -0.072 & $-0.088^{* *}$ \\
\hline & $(0.072)$ & $(0.046)$ & $(0.057)$ & $(0.041)$ & $(0.086)$ & $(0.046)$ & $(0.064)$ & $(0.040)$ \\
\hline Quickly Outdated & 0.436 & $1.790^{* * *}$ & 0.170 & 0.043 & 0.829 & $1.352^{* *}$ & 0.747 & -0.056 \\
\hline & $(0.758)$ & $(0.601)$ & $(0.860)$ & $(0.618)$ & $(0.863)$ & $(0.594)$ & $(0.952)$ & $(0.615)$ \\
\hline Group (D) & 0.175 & 0.036 & 0.080 & -0.043 & $0.390^{* *}$ & 0.001 & 0.067 & -0.057 \\
\hline & $(0.133)$ & $(0.108)$ & $(0.101)$ & $(0.071)$ & $(0.157)$ & $(0.109)$ & $(0.115)$ & $(0.071)$ \\
\hline East Germany (D) & $-0.198^{* *}$ & -0.008 & -0.030 & 0.062 & $-0.183^{*}$ & 0.076 & 0.025 & $0.129^{*}$ \\
\hline & $(0.090)$ & $(0.071)$ & $(0.108)$ & $(0.075)$ & $(0.107)$ & $(0.071)$ & $(0.123)$ & $(0.075)$ \\
\hline Diversity (ln) & & $0.143^{*}$ & & $0.188^{* * *}$ & & $0.174^{* *}$ & & $0.235^{* * *}$ \\
\hline & & $(0.085)$ & & $(0.069)$ & & $(0.085)$ & & $(0.069)$ \\
\hline Market share (ln, L2) & & $0.024^{* * *}$ & & $0.025^{* * *}$ & & $0.018^{* *}$ & & $0.016^{*}$ \\
\hline & & $(0.008)$ & & $(0.009)$ & & $(0.008)$ & & $(0.009)$ \\
\hline Size Class & & & & & & & & \\
\hline W_Industry & 0.000 & & 0.000 & & 0.000 & & 0.000 & \\
\hline Lambda & -0.080 & & 0.653 & & 0.617 & & 0.898 & \\
\hline Chi2 (LR test $\rho=0)$ & 372.725 & & 11.754 & & 272.248 & & 828.971 & \\
\hline P-Value $(\rho=0)$ & 0.000 & & 0.000 & & 0.000 & & 0.000 & \\
\hline No. of Innovators & 622 & & 839 & & 622 & & 839 & \\
\hline Observations & 1,955 & & 1,978 & & 1,955 & & 1,978 & \\
\hline
\end{tabular}

Notes: The regression additionally includes a dummy variable indicating patent stock is zero. (D) denotes dummy variables. (L2) denotes two, and(L3) three year lagged variables.

Source: ZEW: Mannheim Innovation Panel, survey 2011. 


\section{A.3 Innovation Performance: Robustness Check}

Table 3.10: Innovation Success: Sales Share with Innovations

\begin{tabular}{|c|c|c|c|c|c|c|}
\hline \multirow{4}{*}{ Firm Size (ln \# of employees) } & \multicolumn{2}{|c|}{ Innovation } & \multicolumn{2}{|c|}{ Market Novelty } & \multicolumn{2}{|c|}{ Imitation } \\
\hline & Share & yes or no & Share y & yes or no & Share & yes or no \\
\hline & $-1.563^{* *}$ & $0.056^{* * *}$ & $-1.575^{* *}$ & 0.013 & -0.303 & $0.057 * * *$ \\
\hline & $(0.646)$ & $(0.020)$ & $(0.628)$ & $(0.023)$ & $(0.743)$ & $(0.020)$ \\
\hline \multirow{2}{*}{ Productivity (L2) } & 0.495 & -0.017 & 0.567 & 0.033 & 0.252 & -0.003 \\
\hline & $(1.084)$ & $(0.039)$ & $(0.875)$ & $(0.043)$ & $(1.159)$ & $(0.040)$ \\
\hline \multirow[t]{2}{*}{ Marketing intensity } & 81.422 & & 61.060 & & 44.330 & \\
\hline & $(112.201)$ & & $(95.398)$ & & $(114.680)$ & \\
\hline \multirow[t]{2}{*}{ Established Brand (D) } & $8.269^{* * *}$ & & $3.145^{* *}$ & & $6.860^{* * *}$ & \\
\hline & $(1.492)$ & & $(1.548)$ & & $(1.527)$ & \\
\hline \multirow[t]{2}{*}{ New Brand (D) } & 1.750 & & -0.551 & & 0.254 & \\
\hline & $(1.911)$ & & $(1.740)$ & & $(2.033)$ & \\
\hline \multirow[t]{2}{*}{ Trademark (D, L3) } & & $0.241^{* * *}$ & & $0.282^{* * *}$ & & $0.164^{* * *}$ \\
\hline & & $(0.056)$ & & $(0.062)$ & & $(0.056)$ \\
\hline \multirow[t]{2}{*}{ Innovation intensity } & $97.783^{* * *}$ & & 34.360 & & $44.469^{*}$ & \\
\hline & $(27.105)$ & & $(21.968)$ & & $(26.689)$ & \\
\hline \multirow[t]{2}{*}{ High Skilled Labour } & $0.186^{* * *}$ & $0.008 * * *$ & $0.125^{* * *}$ & $* 0.007^{* * *}$ & * $0.164^{* * *}$ & $* 0.006 * * *$ \\
\hline & $(0.041)$ & $(0.001)$ & $(0.041)$ & $(0.001)$ & $(0.044)$ & $(0.001)$ \\
\hline \multirow{2}{*}{ Process Innovation (D) } & $3.763^{* * *}$ & & 1.622 & & $2.574^{* *}$ & \\
\hline & $(1.255)$ & & $(1.405)$ & & $(1.268)$ & \\
\hline \multirow[t]{2}{*}{ Patent stock (ln) } & $2.011^{* *}$ & $0.170 * * *$ & $1.487^{*}$ & $0.134^{* * *}$ & * $1.998^{* *}$ & $0.129^{* * *}$ \\
\hline & $(0.879)$ & $(0.041)$ & $(0.843)$ & $(0.036)$ & $(1.003)$ & $(0.037)$ \\
\hline \multirow[t]{2}{*}{ Continuous R\&D (D) } & $2.789^{*}$ & & 1.059 & & 1.069 & \\
\hline & $(1.460)$ & & $(1.652)$ & & $(1.497)$ & \\
\hline \multirow[t]{2}{*}{ External R\&D (D) } & -0.742 & & -0.358 & & -0.142 & \\
\hline & $(1.478)$ & & $(1.574)$ & & $(1.512)$ & \\
\hline \multirow[t]{2}{*}{ Cooperation (D) } & 1.017 & & $3.110^{* *}$ & & -2.296 & \\
\hline & $(1.453)$ & & $(1.569)$ & & $(1.463)$ & \\
\hline Exporter (D) & $5.224^{* *}$ & $0.424^{* * *}$ & 2.505 & $0.444^{* * *}$ & $* 6.260^{* *}$ & $0.330^{* * *}$ \\
\hline & $(2.329)$ & $(0.055)$ & $(2.442)$ & $(0.067)$ & $(2.495)$ & $(0.056)$ \\
\hline Firm age & $-6.028^{* * *}$ & $-0.140^{* * *}$ & $-5.418^{* * *}$ & $-0.141^{* * *}$ & $*-4.703^{* * *}$ & * $-0.119^{* * *}$ \\
\hline & $(0.931)$ & $(0.030)$ & $(1.006)$ & $(0.035)$ & $(1.046)$ & $(0.030)$ \\
\hline Quickly Outdated & $21.810^{*}$ & $0.863^{* *}$ & -0.196 & $1.450^{* * *}$ & $* 21.295$ & 0.644 \\
\hline & (11.991) & $(0.420)$ & $(12.996)$ & $(0.498)$ & $(13.013)$ & $(0.419)$ \\
\hline Group (D) & -1.036 & -0.053 & $-3.032^{*}$ & 0.010 & 0.262 & -0.063 \\
\hline & $(1.655)$ & $(0.058)$ & $(1.726)$ & $(0.066)$ & $(1.860)$ & $(0.058)$ \\
\hline East Germany (D) & 1.941 & 0.043 & $-2.880^{*}$ & -0.024 & $3.980^{* *}$ & $0.109^{* *}$ \\
\hline & $(1.484)$ & $(0.050)$ & $(1.625)$ & $(0.060)$ & $(1.681)$ & $(0.051)$ \\
\hline Diversity (ln) & & $0.173^{* * *}$ & & 0.027 & & $0.204^{* * *}$ \\
\hline & & $(0.053)$ & & $(0.062)$ & & $(0.052)$ \\
\hline Market share (ln, L2) & & $0.023^{* * *}$ & & $0.043^{* * *}$ & & $0.017^{* * *}$ \\
\hline & & $(0.006)$ & & $(0.007)$ & & $(0.006)$ \\
\hline W_Industry & 0.000 & & 0.000 & & 0.000 & \\
\hline Lambda & 18.216 & & 8.504 & & 25.719 & \\
\hline Chi2 (LR test for $\rho=0)$ & 258.232 & & 139.145 & & 124.711 & \\
\hline P-Value $(\rho=0)$ & 0.000 & & 0.000 & & 0.000 & \\
\hline No. of Innovators & 1,478 & & 716 & & 1,246 & \\
\hline Observations & 3,950 & & 3,950 & & 3,950 & \\
\hline
\end{tabular}

Notes: The regression additionally includes a dummy variables indicating patent stock is zero. Source: ZEW: Mannheim Innovation Panel, survey 2011. 


\section{Chapter 4}

\section{The Dynamic Relationship} between Investments in Brand Equity and Firm Profitability: Evidence using Trademark Registrations $^{7}$

\subsection{Introduction}

Most marketing practitioners and scholars agree that marketing assets such as brand equity significantly contribute to a firm's financial performance. As an asset, brand equity provides value to the firm today and in the long-term. But when do brandrelated investments actually impact firm performance? Most studies looking at the relationship between marketing efforts and brand equity focus on consumers and identify short-term effects (Yoo et al., 2000; Buil et al., 2013). However, the long-term relationship between brand-related investments and firm performance is also important. Marketing practitioners need this information to formulate accurate marketing strategies and provide management with realistic expectations about productivity of marketing efforts (Rust et al., 2004).

Marketing researchers interested in the long-run value of brand equity generally follow two approaches. The first approach exploits the forward-looking nature of pricing in an efficient capital market. A firm's valuation in the capital market is considered to reflect investors' expectations about future cash flows. Simon and Sullivan (1993) estimate brand equity by separating a firm's market valuation into its tangible asset (book values) and (the remaining) intangible asset component. They apply a Tobin's Q approach and decompose intangible assets further to estimate

\footnotetext{
${ }^{7}$ This chapter is co-written with Dirk Czarnitzki (KU Leuven) and Andrew A. Toole (USDA Research Group).
} 
brand equity based on the forward looking capital market valuation. While Simon and Sullivan (1993) use advertising expenditures to estimate brand equity, Sandner and Block (2011), who also apply a Tobin's Q approach, focus on trademark registrations. They confirm a positive effect of trademark stocks on firm value. The second approach uses acquisition transactions to infer the long-run value of brand equity. For instance, Bahadir et al. (2008) make use of 133 M\&A transactions of U.S.-based public firms, for which the acquirer of a firm reports the assessed dollar value of the target brand portfolio. The assigned value represents a forward-looking measure of expected cash flows that are attributable to the brand portfolio. They find the value of a diversified brand portfolio to be more valuable. While quite informative, these approaches do not explain how past marketing efforts created the current brand equity estimate. Marketing managers would benefit from a better understanding of the dynamic relationship between past marketing investments and the current value of brand equity.

In this paper, we study the relationship between past brand-related investments and current financial performance. Financial performance is measured using the firm's profit margin. This indicator captures both revenue and cost effects of brand equity. We model brand equity as a stock that results from up to thirty years of past brand-related investment flows. This formulation is possible due to the availability of consistent time series on a firm's trademark registrations, which serve as annual proxy variables for the firm's brand-related investments. Our approach reveals the dynamic profile between past brand-related investments and current profitability.

Based on a sample of public and private firms in Germany, our results show that brand equity has a significant long-run impact on firm financial performance. The dynamic profile of brand-related investments has an inverted-U shape. On average, it takes twelve years before investments into brand equity have their peak impact on profits. Brand-related investments do not show any return in the first four years and brand-investments older than twenty-three years are not significantly related to current profits. For the median trademarking firm, the estimated annual profit contribution of brand equity amounts to 273,000 Euros.

\subsection{Prior Literature and Conceptual Framework}

\subsubsection{Brand Investments and Brand Equity}

In the literature, a number of conceptual models suggest that brand equity mediates the relationship between a firm's marketing actions and its subsequent financial performance. Rust et al. (2004) present a "chain of marketing productivity" model in which tactical marketing choices such as advertising and branding initiatives affect brand equity before showing up as changes in the firm's financial position. Keller and Lehmann (2006) emphasize that company marketing programs first impact how 
consumers think and feel, then influence their purchasing decisions, and finally affect firm performance. Raggio and Leone (2007) suggest that brand-related marketing efforts influence intrapersonal brand equity before showing up as brand value to the firm. The predominant view seems to be that firm-level outcomes ultimately reflect consumer-level effects such as brand knowledge, loyalty, associations, and so forth (Ailawadi et al., 2003).

At the consumer-level, brand equity is inherently multidimensional and unobservable. It might initially be synonymous with a branded product or service, but over time it can develop qualities that exist above and beyond the objective product or service such as customer awareness, perception of desirable overall quality, and favorable associations (Keller and Lehmann, 2006). In this sense, the development of brand equity is likely to take time, but once a brand becomes familiar, people will select those products or services over an unknown brand (Aaker, 1991).

It is well understood that a company's brand equity is built over time through a variety of management choices such as expenditures on advertising, promotions, market research, loyalty programs, distribution channel development, product-quality and customer service efforts, and new product development (Kirk et al., 2013). Advertising is one of the most visible and most expensive marketing activities, but the direct effects of advertising expenditures are not durable. For instance, Vakratsas and Ambler (1999) and Wang et al. (2009) note that advertising expenditures exert an impact on sales that dies out over a relatively short period of time. Advertising helps, however, to achieve a high level of brand awareness, which is necessary to build brand equity (Keller, 2013). The indirect effects of advertising can thus be long-lasting and might help to accumulate customer's awareness and knowledge about the brand (Wang et al., 2009). The awareness of a brand might affect potential customers to purchase and thus evaluate the product or service.

The positive evaluation of the branded product is necessary for building a strong brand (Farquhar, 1989, 1990). The evaluation of a product enables customers to assess (i) how functional or effective the product is, (ii) how reliable it is, (iii) how durable it is, (iv) how easy it is to use, (v) how it tastes, sounds or smells and (vi) what side effects it may have (WIPO, 2013, p.81). The evaluation creates brand knowledge, which is more than just objective characteristics of the brand. It encompasses the thoughts, feelings, perceptions, images, experiences, and so on that become linked to the brand in the minds of customers (Leone et al., 2006).

The positive evaluation of a company's goods is not sufficient to build brand equity. Customers have to keep the positive experience with the product or service in mind. The message for marketing practitioners is to focus on a unique aspect of the brand that is easy for consumers to remember (Farquhar, 1989, 1990). A memorable name, an easy to recognize symbol or even a notably packaging might represent such a unique aspect of a brand. Srinivasan et al. (2011) call the unique and memorable aspects of a brand the symbol system that firms use as the public face of the brand. 
The symbol system enables customers to identify the goods and services they prefer for whatever reasons. The symbols that represent a brand are, however, only valuable as long as it is impossible for other companies to use confusingly similar symbols (Economides, 1998). Trademarks allow firm's to protect the symbol system of their brands against competitors, who might want to confuse customers with similar symbols (Srinivasan et al., 2011; von Graevenitz, 2007; Aaker, 1991). The European law (Article 2, Directive 2008/95/EC of the European Parliament and of the Council) defines a trademark as follows: "A trade mark may consist of any signs capable of being represented graphically, particularly words, including personal names, designs, letters, numerals, the shape of goods or of their packaging, provided that such signs are capable of distinguishing the goods or services of one undertaking from those of other undertakings." A firm might use a bundle of trademarks to protect different aspects of the representation of the symbol system of its brand. The Coca-Cola brand, for example, is one of the most valuable brands world-wide and protected in Germany by a rich bundle of over 100 trademarks. These trademarks protect the word Coca-Cola, the figure of the distinctive lettering, the famous "waisted" bottle shape, as well as several marketing slogans.

Brand equity, even if legally protected, will dissipate over time unless maintained (Aaker, 1991). Firm's brand-building activities to maintain brand equity might be accompanied by related trademark registrations. This includes marketing campaigns, which might cause the trademark protection of image-related messages (Krasnikov et al., 2009) and the introduction of new products under the brand. Examples for such brand extensions are the introduction of Coca-Cola light, CocaCola zero, and Coca-Cola life.

Trademarks are perhaps the most effective instrument at establishing a durable or long lasting impression on potential buyers. They incorporate durable symbols, words, and signs that consumers are likely to remember. Trademarks establish brand differentiation, help to avoid confusion among customers, allow to build reputational capital and are a key strategic tool for the long-term development of brand equity (Srinivasan et al., 2011). Managers can choose to renew existing trademarks and introduce new trademarks that reinforce and maintain existing brand image in the minds of consumers. For these reasons, a company's history of trademark registration can serve as a proxy for the firm's investments into its brand equity.

\subsubsection{Brand Equity and Firm Profitability}

For our analysis, the firm's economic performance metric must reflect the value of brand equity along with all other factors that influence firm performance. Prior research shows that brand equity can influence a firm's performance by increasing revenues and/or by decreasing costs (Simon and Sullivan, 1993; Ailawadi et al., 2003;

Keller and Lehmann, 2006; Raggio and Leone, 2007; Krasnikov et al., 2009). On 
the revenue side, Ailawadi et al. (2003) highlight that brand equity can influence both price and quantity. Simon and Sullivan (1993) emphasize the effect of brand equity on lowering a firm's production and marketing costs. In our framework, brand equity is the contribution of a firm's branded products and services to its profitability compared to the firm's profitability without having brands (Dubin, 2007). To capture both channels of influence, we use a firm's profit margin, also called excess return on sales. We follow closely Czarnitzki and Kraft (2010) where the excess return on sales is expressed as follows:

$$
\frac{\pi}{S}=\frac{S-\text { labour cost }- \text { capital cost }- \text { material cost }}{S}
$$

with $\pi$ representing profits and $\mathrm{S}$ is sales. If firms are in the long-run equilibrium and operate in a production range in which their production functions are characterized by constant returns to scale, excess return on sales (averaged across all products produced by the firm) will equal the Lerner index. With constant returns to scale, marginal costs (MC) are equal to average costs (AC) and the Lerner index $L$ can be written as:

$$
L=\frac{p-M C}{p}=\frac{p q-A C q}{p q}=\frac{\pi}{S}
$$

with $p$ being price and $q$ the quantity produced. Hence, our measure of profitability is the firm's price-cost margin adjusted for capital costs, or simply profit margin.

We model the firm's profit margin at a point in time as a function of its stock of brand equity and other firm-level determinants (Jaffe, 1986; Czarnitzki and Kraft, 2010; Rexhäuser and Rammer, 2014; Stahl et al., 2012)

$$
P M_{i t}=\beta_{0}+\beta_{1} * \text { BrandEquity }_{i t}+X_{i t} \delta+\eta_{i}+\xi_{t}+u_{i t}
$$

where $P M_{i t}$ is firm $i^{\prime} s$ profit margin in year $t$. BrandEquity ${ }_{i t}$ is the (unobserved) stock of brand equity of firm $i$ at time $t$. $X$ is a vector of control variables capturing other influences on profit margins (described in the next section in chapter 4.3.5). Analogous to Griliches (1979) treatment of a firm's knowledge capital, we model the firm's unobserved stock of brand equity at a point in time as reflecting current and past levels of brand-related investments:

$$
\text { BrandEquity }_{i t}=\theta_{i}+\sum_{j=0}^{k} \alpha_{j} T M_{i t-j}+\mu_{t}+v_{i t}
$$

As noted by Corrado and Hao (2014), part of the value of a company's brand is likely to be captured by a time-constant firm-specific component. $\theta_{i}$ is the firmspecific level of brand equity regardless of whether the firm makes any brand-related investments (Raggio and Leone, 2009). The $\alpha_{j}$ coefficients measure the fraction of 
the firm's past brand-related investments that contribute to brand equity at time t. $\mu_{t}$ is the trend component capturing all other time-varying influences on the company's brand equity that are outside the control of the firm. $v_{i t}$ is a random transitory component that captures unexpected "shocks" to the firm's accumulated level of brand equity. Substituting (4.2) into (4.1) gives:

$$
P M_{i t}=\phi_{0}+\sum_{j=0}^{k} \gamma_{j} T M_{i t-j}+\mathbf{X}_{i t} \delta+\eta_{i}+\tau_{t}+\epsilon_{i t}
$$

where $\phi_{0}=\beta_{0}+\left(\theta_{i} * \beta_{1}\right), \gamma_{j}=\alpha_{j} * \beta_{1}, \tau_{t}=\xi_{t}+\beta_{1} * \mu_{t}$ and $\epsilon_{i t}=\beta_{1} * v_{i t}+u_{i t}$. The primary coefficients of interest are the $\gamma_{j}$. These coefficients reveal the dynamic contribution of brand-related investments on the firm's current profit margin. Notice that $\gamma_{j}$ combines the effect of brand-related investment in year $t-j$ on brand equity in year $t, \alpha_{j}$, with the coefficient $\beta_{1}$, which reveals how brand equity in year $t$ contributes to the firm's profit margin. Notice further that the calculation of a trademark capital stock and assumptions about an appropriate depreciation or appreciation rate are not needed. With a sufficiently long and complete time series of brand-related investments and appropriate assumptions about $\epsilon_{i t}$, equation (4.3) could be estimated directly. However, long and complete time series data on firmlevel brand-related investments do not exist. Instead, we use proxy variables for a firm's annual flow of brand-related investments, $T M_{i t-j}$. Proxy variables allow us to estimate the shape of the lag distribution that characterizes how past brand-related investments contribute to current profits. For our empirical implementation, we use a firm's annual number of trademark registrations as proxy variables for past brandrelated investments. Trademarks have been used as proxy variables for marketing investments in at least two prior studies (Fosfuri and Giarratana, 2009; Ceccagnoli et al., 2010).

Prior research using trademarks in the economics and marketing literatures creates stocks of trademarks for each company instead of using trademark flows. For instance, Sandner and Block (2011) sum all past trademarks under the assumption there is no "depreciation" of the effectiveness of individual trademarks over time. This approach assumes the $\alpha_{t}$ are constant and equal to one across all years $\left(\alpha_{j}=1\right)$ in equation (4.2). In a recent contribution to the marketing literature, Krasnikov et al. (2009) follow the same methodology. In our empirical analysis, we are able to relax this assumption. We hypothesize that the dynamic relationship between past investments in brand equity and current profitability is not constant or monotone. The contribution of a trademark to brand equity might be small in the beginning as firms try to build consumer awareness and experience. As marketing efforts have their impact, the value of brand equity is likely to rise. Furthermore, past investments in brand equity are likely to depreciate in the sense that these investments do not have the same effect on current profitability. To allow for a non-linear rela- 
tionship between past investments and current profitability, we implement a vintage model that uses flows rather than stocks.

\subsection{Data and Estimation Method}

\subsubsection{Data}

Most of our firm-level data come from the Mannheim Innovation Panel, which constitutes the German part of the European Community Innovation Survey (CIS). The survey is a stratified random sample (by sector, size, and region) that targets the population of all German firms with at least five employees in manufacturing and service industries. The survey is conducted annually since 1993 by the Centre for European Economic Research (ZEW) and asks firms to report general and innovation related information covering the prior three years. The methodology and questionnaires are internationally harmonized across the countries and based on the so-called Oslo Manual: "Proposed Guidlines for Collecting and Interpreting Technological Innovation Data" (OECD, Eurostat, 2005). German CIS data provide an additional layer of quality through extensive nonresponse surveys and are considered to be of high quality (Eurostat, 2013). Further information on the survey methodology, data, and validity is provided by Peters (2008) and Aschhoff et al. (2013).

This study combines the German CIS information for the period from 2001 through 2010 with administrative data on each firm's trademark and patenting activity. The trademark data come from the Office for Harmonization in the Internal Market (OHIM) and the German Patent and Trade Mark Office (DPMA). The OHIM data reflect trademarks valid in all European Union (EU) member states while the DPMA trademarks are specific to Germany. In the empirical model, we will also control for patent applications by the firms. Patent application data come from the European Patent Office (EPO) and Germany's DPMA. All administrative data were matched to the German CIS using assignee name and address information and specialized software developed at the Centre for European Economic Research. The final database is an unbalanced panel of 11,789 firms with a total of 38,431 firm-year observations. It is unbalanced because firms do not always respond to the survey. About $4 \%$ of the firms have 10 years of data, another $10 \%$ have at least 8 years of data, $45 \%$ have 4 years of data, and the remaining $41 \%$ have less than 4 years.

\subsubsection{Dependent Variable: Firm Profitability}

Because firms typically view their return on sales as proprietary, the MIP survey question was designed to obtain interval responses as opposed to exact figures. Respondents could choose from among seven categories: less than 0 percent, 0 to less 
than 2 percent, 2 to less than 4 percent, 4 to less than 7 percent, 7 to less than 10 percent, 10 to less than 15 percent, and 15 percent and more. ${ }^{8}$

Figure 4.1: Distribution of Firm Profitability

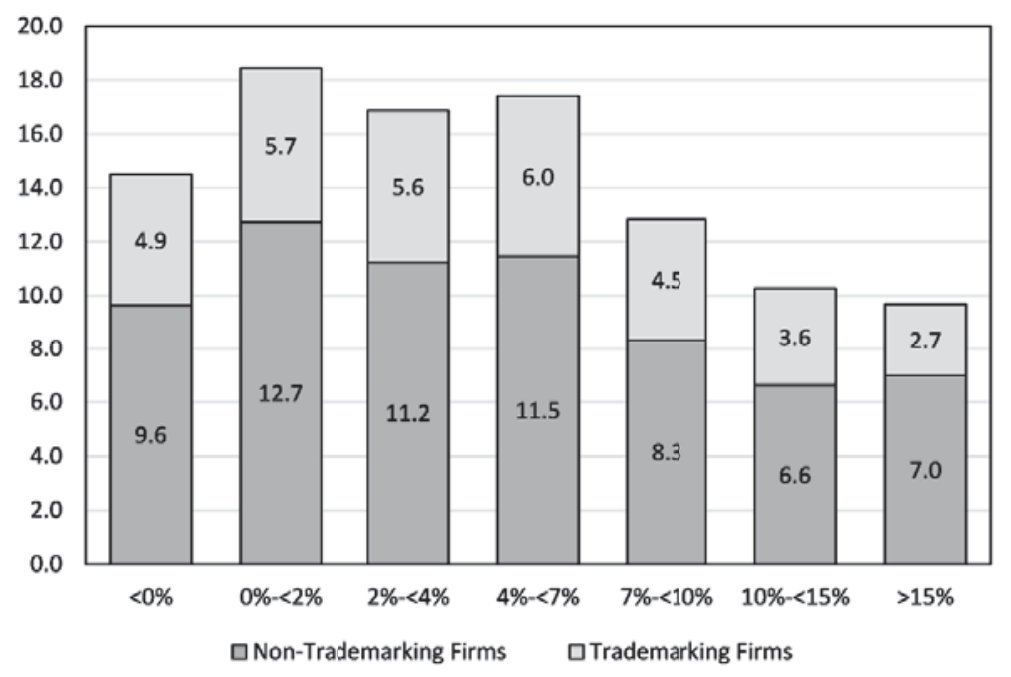

For all 11,789 firms in the sample, Figure 4.1 shows the distribution of return on sales, which we call profit margin for simplicity. The category of the lowest profitability is those with profit margins of "less than $0 \%$ ". Firms in this category are making losses in the respective year of observation and their proportion is remarkable high at around $15 \%$. Slightly more than half of the firms achieve profit margins between $0 \%$ and $7 \%$, almost equally distributed across the three categories. About a third of the firms achieved profit margins of more than $7 \%$.

The column percentage in Figure 4.1 is divided into those firms with at least one active trademark and those without. So, for instance, for the $14.2 \%$ of the firms in column 1 with profit margins of "less than $0 \%$ ", we see that $4.9 \%$ had trademarks and $9.6 \%$ had not. While a disproportionate small proportion of $31 \%$ of the firms with trademarks belong to the low profit margin category of $0 \%$ to $2 \%$, a disproportionate large number of $34.7 \%$ of them belong to the three high profit margin categories between $4 \%$ and 15\%. Firms with trademarks are also under-represented in the highest category ("more than 15\%").

\subsubsection{The Trademark Measure of Brand Equity}

We proxy for a firm's brand-related investment using thirty years of trademark activity. One of the main advantages of using trademarks to proxy for investments into brand equity is that comprehensive administrative data are publicly available. For the German firms in this study, administrative data includes more than 1.5

\footnotetext{
${ }^{8}$ In the years 2009 and 2010, the category "less than zero" was further differentiated but grouped together for better comparability.
} 
million trademarks registered at DPMA since 1894 and nearly 0.9 million Community trademarks since the foundation of OHIM in 1996. The combined DPMA and OHIM data allow us to have a long time series on the number of trademarks each firm registered. We use the registration date of the trademarks and use only trademarks that are still valid (active). Trademarks expire after 10 years, unless the firm renews them. Similar to Krasnikov et al. (2009), we assume expired trademarks, which are no longer valid, do not contribute to firm profitability.

Figure 4.2: Age Distribution of Trademarks in 2010

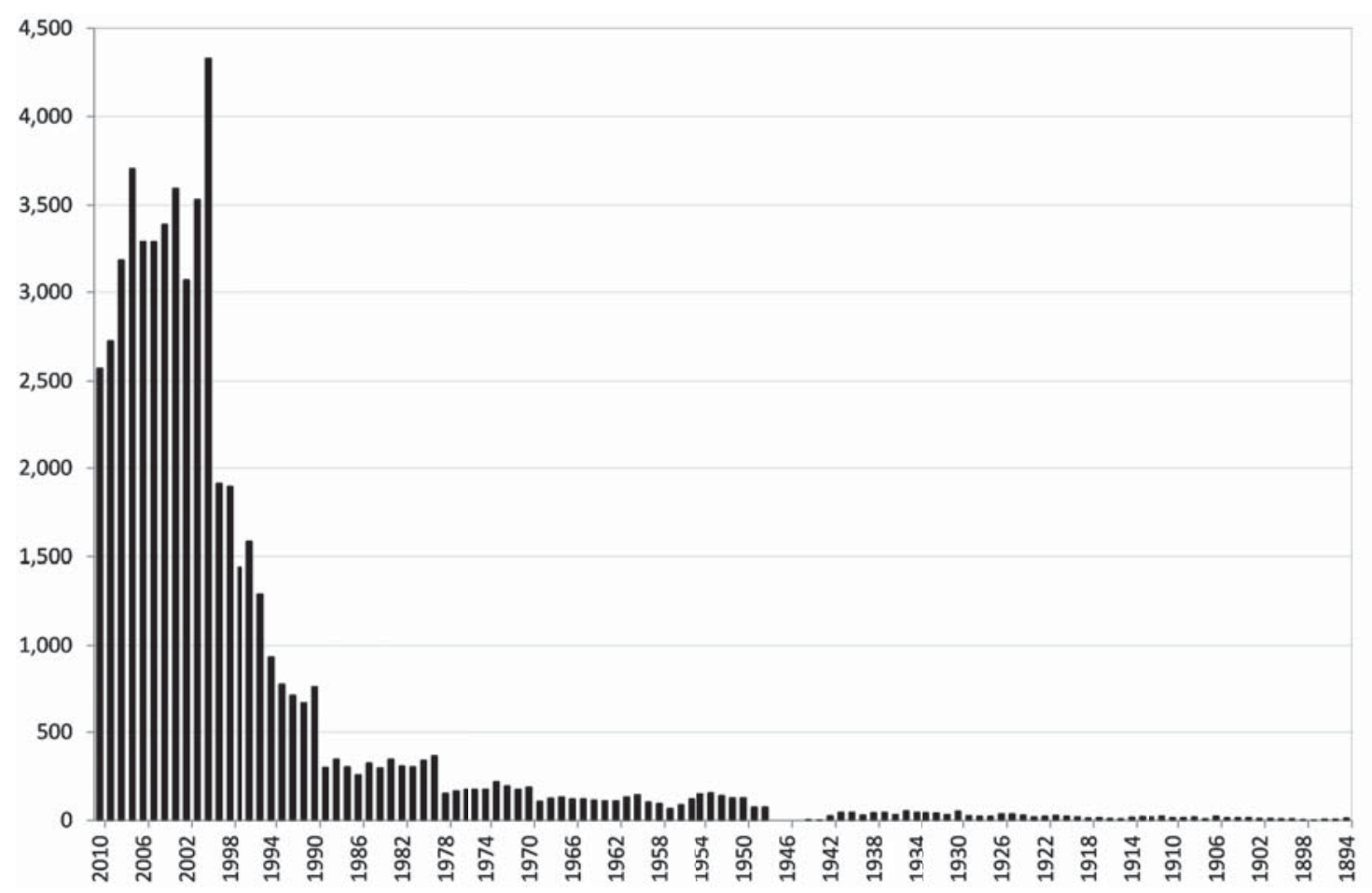

Source: ZEW: Mannheim Innovation Panel.

Figure 4.2 shows the age distribution of registered and valid trademarks in our data for the year 2010. Most trademarks are less than eight years old and the number of valid trademarks falls quickly with age. This is caused by two effects: the number of trademark registrations has increased tremendously since the early 1990's (Schautschick and Greenhalgh, 2013) and a considerable proportion of registered trademarks is not renewed and expires after the protection period of ten years. Of the trademarks that have been registered in 1999, only $54 \%$ have been extended.

For our empirical analysis, we restrict the age range to be a maximum of thirty years. This range covers the large majority of over $90 \%$ of all valid trademarks in our sample. While it is possible that branding investments which were made more than thirty years in the past are still influencing profitability, the literature points out that brands need continual investment to maintain their equity in the eyes of consumers (Keller, 2013). It is likely that firms have introduced new trademarks over 
time that build on and support the older trademarks to maintain brand awareness markets with ever changing demographics. For example, Coca-Cola has a portfolio of 707 trademarks (at DPMA and OHIM) [newest 2014, oldest 1926, which is the classic coke trademark Cad Coda], but only 61 are older than thirty years (8.6\%). While those $8.6 \%$ of Coca-Cola's trademarks are the "classics," it is reasonable to believe that they maintain their value over generations of consumers due to the introduction of new and related trademarks.

\subsubsection{Empirical Implementation}

We estimate the contribution of brand equity to firm profits using firm-level panel data. In the survey, firms reported profit margins in intervals. To account for this, we used an ordered probit regression model with known thresholds. Since we know the thresholds of the categories, we are able to interpret the coefficients of the estimation directly as marginal effects (Wooldridge, 2002, p. 508). The panel structure of the data allows us to estimate both pooled regression models and random effects models, which have the added feature of controlling for firm-level unobserved heterogeneity as indicated in Equation (4.3).

Our data allow us to use thirty years of annual trademark registration flows to proxy for brand-related investments. To avoid problems of multicollinearity, prior research used a stock formulation; however, to estimate the distributed lag we require a different specification. Following Griliches (1979), we allow the distributed lag to have a polynomial shape by using an Almon formulation. Following the Weierstrasstheorem, the Almon approach to distributed-lag models assumes that $\gamma_{j}$ can be approximated by a suitable-degree polynomial in $j$, the length of the lag. A second order polynomial in $j$, the length of the lag, allows for both: a linear increase or decrease as well as an increase at first and then decrease of the economic value of an average trademark. We follow closely the description of the Almon approach in Gujarati (2003).

The flow of trademarks for 30 years is approximated by the second-degree polynomial $^{9}$

$$
\gamma_{j}=a_{0}+a_{1} j+a_{2} j^{2}
$$

\footnotetext{
${ }^{9}$ We used also a third-degree polynomial, see section 4.4 on econometric results. As we will discuss below, the results concerning the shape of the value creation by trademarks in our vintage model did not depend on the degree of the polynomial.
} 
Substituting (4.4) into (4.3), we obtain

$$
\begin{aligned}
P M_{i t} & =\phi_{0}+\sum_{j=0}^{k}\left(a_{0}+a_{1} j+a_{2} j^{2}\right) T M_{i t-j}+\mathbf{X}_{i t} \delta+\tau_{t}+\varepsilon_{i t} \\
& =\phi_{0}+a_{0} \sum_{j=0}^{k} T M_{i t-j}+a_{1} \sum_{j=0}^{k} j T M_{i t-j}+a_{2} \sum_{j=0}^{k} j^{2} T M_{i t-j}+\mathbf{X}_{i t} \delta+\tau_{t}+\varepsilon_{i t}
\end{aligned}
$$

Defining

$$
\begin{aligned}
& Z_{1 t}=\sum_{j=0}^{k} T M_{t-j} \\
& Z_{2 t}=\sum_{j=0}^{k} j T M_{t-j} \\
& Z_{3 t}=\sum_{j=0}^{k} j^{2} T M_{t-j}
\end{aligned}
$$

The equation simplifies to

$$
P M_{i t}=\phi_{0}+a_{0} Z_{1 t}+a_{1} Z_{2 t}+a_{2} Z_{3 t}+\mathbf{X}_{i t} \delta+\tau_{t}+\varepsilon_{i t}
$$

In the Almon scheme $P M$ is regressed on the constructed variables $Z$ (or AlmonPolynomial Terms), not on the original $T M$ variables. Once the Almon-Polynomial terms are calculated, the original $\gamma$ 's can be estimated from

$$
\hat{\gamma}_{j}=\hat{a}_{0}+\hat{a}_{1} j+\hat{a}_{2} j^{2}
$$

The resulting beta coefficients for each of the 30 lags can be interpreted as marginal effects on a firm's profit margin.

\subsubsection{Control Variables}

A firm's profit margin may be influenced by a variety of other firm-specific and external factors. As firm-specific drivers we include firm size and its square, firm age, region, export orientation, and the type of ownership. Firm size is measured by the number of employees and firm age in years (both in logs). A region dummy indicates whether the firm's headquarter is located in East Germany and an exporter dummy whether the firm serves international markets. The type of ownership distinguishes between unaffiliated firms (reference group) and those that belong to a group, controlling for synergy (dis)advantages. Among external factors, market structure is captured by the Herfindahl concentration index, which is a measure for imperfect competition. We take barriers to entry into account by including capital intensity. 
Capital intensity is defined as the logarithm of the tangible assets per employee, which is direct information from the survey.

Table 4.1: Descriptive Statistics of Main Variables

\begin{tabular}{lccrrr}
\hline & Median & Mean & Std.Dev. & Min. & Max. \\
\hline Profit Margin & 4.00 & 3.65 & 1.87 & 1.00 & 7.00 \\
Trademarks (D) $_{\text {Trademark Stock }}{ }^{1}$ & 0.00 & 0.33 & 0.47 & 0.00 & 1.00 \\
Firm Size $_{\text {Capital Intensity }}$ & 3.00 & 3.96 & 28.13 & 0.00 & 1200.00 \\
EPO Patent (D) & -3.86 & -3.84 & 1.72 & 0.00 & 13.17 \\
Product Innovation (D) & 0.00 & 0.14 & 1.53 & -11.95 & 3.58 \\
Process Innovation (D) & 0.00 & 0.47 & 0.50 & 0.00 & 1.00 \\
Herfindahl Index & 0.00 & 0.47 & 0.79 & 0.00 & 1.00 \\
Exporter (D) & 0.00 & 0.47 & 0.02 & 0.00 & 4.00 \\
Firm Age & 2.77 & 2.83 & 1.14 & -0.69 & 1.00 \\
Group (D) & 0.00 & 0.31 & 0.46 & 0.00 & 1.00 \\
East Germany (D) & 0.00 & 0.32 & 0.47 & 0.00 & 1.00 \\
\hline
\end{tabular}

1 The variable Trademark Stock captures all valid trademarks over the last 30 years and corresponds to the first Almon-Polynomial Term.

Source: ZEW: Mannheim Innovation Panel.

Innovative activities are supposed to be another important determinant of profitability. A firm's patents at the European Patent Office (EPO), as well as the introduction of product and process innovation, capture the successful outcome of innovative activity. We use a dummy variable that indicates whether the firm has at least one granted patent at the EPO. The introduction of product innovation and process innovation in the preceding three years are also captured by dummy variables.

Furthermore, we include time dummies and 12 industry dummies to control for industry characteristics that are not measured by the other structural variables. Firms are assigned to these industries on the basis of their most important activity. Descriptive statistics of the main variables are presented in Table 4.1 and the definition of the variables are provided in Table 4.4 in the Appendix.

\subsection{Econometric Results}

We estimate both, pooled and random effects models to analyse the effect of brandrelated investments on a firm's profit margin. Both models yield quite similar results, but the conducted LR test rejects the null hypothesis of the pooled model and thus confirms a significant contribution of the panel-level variable. We depict results for the pooled model in the Appendix but focus here on the estimates of the random effects model and present the results of four different model specifications in Table 4.2. 
The estimated coefficients directly identify the marginal effects.

Consistently across different specifications, we find significance for firm size, innovation activity, and firm age. Firm size is negatively associated with the profit margin for firms up to 1,100 employees (what applies to roughly $95 \%$ of the sample) and increases again slightly for larger firms. Older firms achieve higher profit margins, pointing to a learning curve effect. The innovation activity, the patent protection of technological knowledge, and the introduction of product as well as process innovations is associated with higher profit margins. In contrast to the results of the pooled model (presented in Table 4.6 in the Appendix), the estimates of capital intensity, group, and East Germany show no significance in the panel model. As these variables show little within firm variance, their impact is at least partly captured by the firm-specific effects of the panel model. These findings are consistent with related studies for German firms (Czarnitzki and Kraft, 2010; Peters and Schmiele, 2010).

The most important result is the significant positive impact of brand-related investment on firm profitability in each of the four model specifications. The specification is gradually enriched by additional Almon-Polynomial Terms. Additional Almon terms relax the assumption about time lags between brand-related investment and their effect on a firm's profit margin. The first column (1) provides the results for the specification with just the first polynomial term. This specification corresponds in principal to the stock formulation without depreciation, since the flow of trademarks over the 30-year period is added up in the first term. The common stock formulation would also take trademarks into account that are older than the defined 30 -year period. With a correlation of 0.99 , the resulting variables, the first polynomial term and the trademark stock without depreciation, are highly correlated and the alternative estimation with the trademark stock yields nearly the same results. The results confirm a significant positive effect of trademarks on firm profitability. Each trademark, irrespective of its age, has a marginal impact of 0.008 on firm's profits.

The specification in Column (2) includes in addition the second Almon-Polynomial Term. The resulting first-degree, or linear polynomial, relaxes the assumption that trademarks of different ages have the same impact on firm profitability. The specification allows for both a decreasing and an increasing (linear) impact of the age of trademarks. The results show that the Almon-Polynomial terms are jointly significant, but the two coefficients of the Almon-Polynomial Terms are not particularly informative. More informative than the coefficients of the Almon-Polynomial Terms are the estimated $\gamma$ 's for the 30 lag-variables. Using equation (4.8), Table 4.3 provides the corresponding coefficients and standard errors of the Almon-Polynomial Terms for each model specification.

The results show that the marginal effect increases from 0.005 in year 4 after the brand-related investment $\left(\gamma_{4}\right)$ to 0.024 for those that date back 30 years $\left(\gamma_{30}\right)$. This 
Table 4.2: Firm Profitability and the Impact of Brand-related Investments

\begin{tabular}{|c|c|c|c|c|}
\hline & $\begin{array}{c}(1) \\
\text { Stock }\end{array}$ & $\begin{array}{c}(2) \\
\text { Linear }\end{array}$ & $\begin{array}{c}(3) \\
\text { Quadratic }\end{array}$ & $\begin{array}{c}(4) \\
\text { Cubic }\end{array}$ \\
\hline \multicolumn{5}{|l|}{ Brand-related Investments } \\
\hline Trademark Stock & $\begin{array}{l}0.008^{* * *} \\
(0.002)\end{array}$ & & & \\
\hline Almon-Polynomial Term 0 & & $\begin{array}{c}0.002 \\
(0.005)\end{array}$ & $\begin{array}{c}-0.005 \\
(0.007)\end{array}$ & $\begin{array}{c}0.006 \\
(0.011)\end{array}$ \\
\hline Almon-Polynomial Term 1 & & $\begin{array}{c}0.001 \\
(0.001)\end{array}$ & $\begin{array}{l}0.003^{* *} \\
(0.002)\end{array}$ & $\begin{array}{l}-0.002 \\
(0.005)\end{array}$ \\
\hline Almon-Polynomial Term 2 & & & $\begin{array}{c}-0.000^{*} \\
(0.000)\end{array}$ & $\begin{array}{c}0.001 \\
(0.001)\end{array}$ \\
\hline Almon-Polynomial Term 3 & & & & $\begin{array}{l}-0.000 \\
(0.000)\end{array}$ \\
\hline Firm Size & $\begin{array}{l}-0.850^{* * *} \\
(0.105)\end{array}$ & $\begin{array}{l}-0.855^{* * *} \\
(0.105)\end{array}$ & $\begin{array}{l}-0.852^{* * *} \\
(0.105)\end{array}$ & $\begin{array}{l}-0.858^{* * *} \\
(0.105)\end{array}$ \\
\hline Firm Size Squared & $\begin{array}{l}0.060^{* * *} \\
(0.012)\end{array}$ & $\begin{array}{l}0.061^{* * *} \\
(0.012)\end{array}$ & $\begin{array}{l}0.060^{* * *} \\
(0.012)\end{array}$ & $\begin{array}{l}0.061^{* * * *} \\
(0.012)\end{array}$ \\
\hline Capital intensity & $\begin{array}{c}0.024 \\
(0.025)\end{array}$ & $\begin{array}{c}0.024 \\
(0.025)\end{array}$ & $\begin{array}{c}0.024 \\
(0.025)\end{array}$ & $\begin{array}{c}0.024 \\
(0.025)\end{array}$ \\
\hline EPO Patent (D) & $\begin{array}{c}0.259^{*} \\
(0.154)\end{array}$ & $\begin{array}{c}0.252 \\
(0.154)\end{array}$ & $\begin{array}{c}0.256^{*} \\
(0.154)\end{array}$ & $\begin{array}{c}0.255^{*} \\
(0.154)\end{array}$ \\
\hline Product Innovation (D) & $\begin{array}{l}0.295^{* * *} \\
(0.059)\end{array}$ & $\begin{array}{l}0.295^{* * *} \\
(0.059)\end{array}$ & $\begin{array}{l}0.294^{* * *} \\
(0.059)\end{array}$ & $\begin{array}{l}0.294^{* * *} \\
(0.059)\end{array}$ \\
\hline Process Innovation (D) & $\begin{array}{c}0.060^{*} \\
(0.034)\end{array}$ & $\begin{array}{c}0.060^{*} \\
(0.034)\end{array}$ & $\begin{array}{c}0.060^{*} \\
(0.034)\end{array}$ & $\begin{array}{c}0.061^{*} \\
(0.034)\end{array}$ \\
\hline Herfindahl index & $\begin{array}{c}0.767 \\
(2.231)\end{array}$ & $\begin{array}{c}0.748 \\
(2.231)\end{array}$ & $\begin{array}{c}0.733 \\
(2.231)\end{array}$ & $\begin{array}{c}0.710 \\
(2.231)\end{array}$ \\
\hline Exporter (D) & $\begin{array}{c}0.077 \\
(0.092)\end{array}$ & $\begin{array}{c}0.076 \\
(0.092)\end{array}$ & $\begin{array}{c}0.077 \\
(0.092)\end{array}$ & $\begin{array}{c}0.076 \\
(0.092)\end{array}$ \\
\hline Firm Age & $\begin{array}{l}0.184^{* * *} \\
(0.044)\end{array}$ & $\begin{array}{l}0.182^{* * *} \\
(0.044)\end{array}$ & $\begin{array}{l}0.182^{* * *} \\
(0.044)\end{array}$ & $\begin{array}{l}0.182^{* * *} \\
(0.044)\end{array}$ \\
\hline Group (D) & $\begin{array}{c}0.030 \\
(0.093)\end{array}$ & $\begin{array}{c}0.028 \\
(0.093)\end{array}$ & $\begin{array}{c}0.029 \\
(0.093)\end{array}$ & $\begin{array}{c}0.030 \\
(0.093)\end{array}$ \\
\hline East Germany (D) & $\begin{array}{l}-0.167 \\
(0.116) \\
\end{array}$ & $\begin{array}{l}-0.166 \\
(0.116) \\
\end{array}$ & $\begin{array}{c}-0.168 \\
(0.116) \\
\end{array}$ & $\begin{array}{l}-0.168 \\
(0.116)\end{array}$ \\
\hline W_Almon & 0.000 & 0.000 & 0.000 & 0.000 \\
\hline W_Industry & 0.000 & 0.000 & 0.000 & 0.000 \\
\hline Log-likelihood & $-66,849.11$ & $-66,848.32$ & $-66,846.96$ & $-66,846.12$ \\
\hline Observations & 38,431 & 38,431 & 38,431 & 38,431 \\
\hline
\end{tabular}

Significance levels: $* * * \mathrm{p}<0.01,{ }^{* *} \mathrm{p}<0.05,{ }^{*} \mathrm{p}<0.1$. Standard errors in parentheses. Notes: Regression additionally includes three dummies indicating exporter, group, and capital intensity are missing. P-values of Wald tests on joint significance are indicated by "W_".

Source: ZEW: Mannheim Innovation Panel, surveys 2002-2011.

increase corresponds to an annual growth rate of about $7 \%$. These findings point to an appreciation of brand-related investment, but the assumptions are still restrictive in the sense that they allow for a linear increase or linear decrease only. 
In specification (3), we relax the assumption of the impact of brand-related investments of different ages even more. We apply a second-order, or quadratic, polynomial by including Polynomial Term 3. The quadratic polynomial allows for a linear increase of the marginal impact of brand-related investments like in specification (2), but also for an initially increase and later decrease or the other way round. The Almon-Polynomial Terms are once again jointly significant and the estimated $\gamma$ 's (see Table 4.3) show the marginal impact of brand-related investments of different ages. Recent brand-related investments have again no significant impact on the profitability of firms. The impact of brand-related investments on profitability becomes significantly positive after four years. The size of the coefficient increases until the thirteenth year and decreases afterwards. The impact of brand-related investments older than nineteen years does not remain significant.

The estimates of an even more flexible polynomial form, a third-order, or cubic polynomial are shown in Column (4). The U-shaped relationship is confirmed in the cubic specification, but the effect of brand-related investment are just after eight years significant. We calculate a likelihood-ratio (LR) test to compare the fit of the cubic with the quadratic model specification. The resulting significance level of 0.1941 points to the fact that the additional third polynomial term is rejected in favour of the quadratic model specification. We prefer thus the quadratic specification presented in Column (3). It provides the most flexible functional form and leads to quite plausible results about the temporal connection of brand-related investments and firm profitability. The $\gamma^{\prime} s$ of model specification (3) are presented in a more illustrative way in Figure 4.3. 
Table 4.3: Resulting Betas (Random-Effects Interval Regression)

\begin{tabular}{|c|c|c|c|c|c|c|c|c|}
\hline & $\begin{array}{r}(1 \\
\text { Poi }\end{array}$ & & $\begin{array}{r}(2) \\
\text { Line }\end{array}$ & $\begin{array}{l}\text { 2) } \\
\text { lear }\end{array}$ & Quad & $\begin{array}{l}\text { 3) } \\
\text { Aratic }\end{array}$ & $\begin{array}{r}(4 \\
\text { Cub }\end{array}$ & $\begin{array}{l}\text { 4) } \\
\text { bic }\end{array}$ \\
\hline & Coef. & Std. Err. & Coef. & Std. Err. & Coef. & Std. Err. & Coef. & Std. Err. \\
\hline$\gamma_{0}$ & $0.008 * * *$ & $(0.002)$ & 0.002 & $(0.005)$ & -0.005 & $(0.007)$ & 0.006 & $(0.011)$ \\
\hline$\gamma_{1}$ & $0.008^{* * *}$ & $(0.002)$ & 0.003 & $(0.004)$ & -0.002 & $(0.005)$ & 0.004 & $(0.007)$ \\
\hline$\gamma_{2}$ & $0.008^{* * *}$ & $(0.002)$ & 0.004 & $(0.004)$ & 0.001 & $(0.004)$ & 0.003 & $(0.004)$ \\
\hline$\gamma_{3}$ & $0.008^{* * *}$ & $(0.002)$ & 0.005 & $(0.003)$ & 0.004 & $(0.003)$ & 0.003 & $(0.004)$ \\
\hline$\gamma_{4}$ & $0.008 * * *$ & $(0.002)$ & $0.005^{*}$ & $(0.003)$ & $0.007^{* *}$ & $(0.003)$ & 0.003 & $(0.004)$ \\
\hline$\gamma_{5}$ & $0.008^{* * *}$ & $(0.002)$ & $0.006^{* *}$ & $(0.003)$ & $0.009 * * *$ & $* \quad(0.003)$ & 0.004 & $(0.005)$ \\
\hline$\gamma_{6}$ & $0.008^{* * *}$ & $(0.002)$ & $0.007^{* * *}$ & $* \quad(0.002)$ & $0.011^{* * *}$ & * $(0.003)$ & 0.006 & $(0.005)$ \\
\hline$\gamma_{7}$ & $0.008^{* * *}$ & k $(0.002)$ & $0.007 * * *$ & $* \quad(0.002)$ & $0.013^{* * *}$ & $* \quad(0.004)$ & 0.008 & $(0.005)$ \\
\hline$\gamma_{8}$ & $0.008^{* * *}$ & $(0.002)$ & $0.008^{* * *}$ & $*(0.002)$ & $0.014^{* * *}$ & * (0.004) & $0.011^{* *}$ & $(0.005)$ \\
\hline$\gamma_{9}$ & $0.008 * * *$ & k $(0.002)$ & $0.009 * * *$ & $* \quad(0.002)$ & $0.015^{* * *}$ & $* \quad(0.004)$ & $0.013^{* * *}$ & $* \quad(0.005)$ \\
\hline$\gamma_{10}$ & $0.008^{* * *}$ & $k^{k}(0.002)$ & $0.010 * * *$ & $* \quad(0.002)$ & $0.016^{* * *}$ & $* \quad(0.005)$ & $0.016^{* * *}$ & * (0.005) \\
\hline$\gamma_{11}$ & $0.008^{* * *}$ & $(0.002)$ & $0.010^{* * *}$ & $*(0.003)$ & $0.017^{* * *}$ & $*(0.005)$ & $0.018^{* * *}$ & * (0.005) \\
\hline$\gamma_{12}$ & $0.008^{* * *}$ & $(0.002)$ & $0.011^{* * *}$ & $*(0.003)$ & $0.017^{* * *}$ & $*(0.005)$ & $0.021^{* * *}$ & $*(0.006)$ \\
\hline$\gamma_{13}$ & $0.008^{* * *}$ & $(0.002)$ & $0.012^{* * *}$ & $* \quad(0.004)$ & $0.018^{* * *}$ & * $(0.005)$ & $0.023^{* * *}$ & $* \quad(0.007)$ \\
\hline$\gamma_{14}$ & $0.008^{* * *}$ & $(0.002)$ & $0.013^{* * *}$ & $*(0.004)$ & $0.017^{* * *}$ & $*(0.005)$ & $0.025^{* * *}$ & $*(0.008)$ \\
\hline$\gamma_{15}$ & $0.008^{* * *}$ & $(0.002)$ & $0.013^{* * *}$ & $*(0.005)$ & $0.017^{* * *}$ & $* \quad(0.005)$ & $0.027^{* * *}$ & * (0.009) \\
\hline$\gamma_{16}$ & $0.008^{* * *}$ & $(0.002)$ & $0.014^{* * *}$ & $*(0.005)$ & $0.016^{* * *}$ & $* \quad(0.005)$ & $0.028^{* * *}$ & * $(0.010)$ \\
\hline$\gamma_{17}$ & $0.008 * * *$ & $\quad(0.002)$ & $0.015^{* *}$ & $(0.006)$ & $0.015^{* * *}$ & $*(0.006)$ & $0.028^{* *}$ & $(0.012)$ \\
\hline$\gamma_{18}$ & $0.008^{* * *}$ & k $(0.002)$ & $0.015^{* *}$ & $(0.006)$ & $0.014^{* *}$ & $(0.006)$ & $0.028^{* *}$ & $(0.012)$ \\
\hline$\gamma_{19}$ & $0.008^{* * *}$ & $(0.002)$ & $0.016^{* *}$ & $(0.007)$ & $0.013^{*}$ & $(0.007)$ & $0.027^{* *}$ & $(0.013)$ \\
\hline$\gamma_{20}$ & $0.008 * * *$ & k $(0.002)$ & $0.017^{* *}$ & $(0.007)$ & 0.011 & $(0.008)$ & $0.025^{*}$ & $(0.013)$ \\
\hline$\gamma_{21}$ & $0.008^{* * *}$ & $(0.002)$ & $0.018^{* *}$ & $(0.008)$ & 0.009 & $(0.009)$ & 0.022 & $(0.014)$ \\
\hline$\gamma_{22}$ & $0.008^{* * *}$ & $(0.002)$ & $0.018^{* *}$ & $(0.009)$ & 0.007 & $(0.011)$ & 0.018 & $(0.014)$ \\
\hline$\gamma_{23}$ & $0.008^{* * *}$ & $(0.002)$ & $0.019^{* *}$ & $(0.009)$ & 0.004 & $(0.013)$ & 0.012 & $(0.014)$ \\
\hline$\gamma_{24}$ & $0.008 * * *$ & $\quad(0.002)$ & $0.020^{* *}$ & $(0.010)$ & 0.002 & $(0.015)$ & 0.005 & $(0.015)$ \\
\hline$\gamma_{25}$ & $0.008^{* * *}$ & $(0.002)$ & $0.020^{* *}$ & $(0.010)$ & -0.001 & $(0.017)$ & -0.003 & $(0.017)$ \\
\hline$\gamma_{26}$ & $0.008^{* * *}$ & $(0.002)$ & $0.021^{* *}$ & $(0.011)$ & -0.005 & $(0.019)$ & -0.013 & $(0.020)$ \\
\hline$\gamma_{27}$ & $0.008^{* * *}$ & $(0.002)$ & $0.022^{*}$ & $(0.011)$ & -0.008 & $(0.022)$ & -0.024 & $(0.025)$ \\
\hline$\gamma_{28}$ & $0.008^{* * *}$ & $(0.002)$ & $0.023^{*}$ & $(0.012)$ & -0.012 & $(0.024)$ & -0.038 & $(0.031)$ \\
\hline$\gamma_{29}$ & $0.008^{* * *}$ & $(0.002)$ & $0.023^{*}$ & $(0.012)$ & -0.016 & $(0.027)$ & -0.053 & $(0.039)$ \\
\hline$\gamma_{30}$ & $0.008^{* * *}$ & $(0.002)$ & $0.024^{*}$ & $(0.013)$ & -0.021 & $(0.030)$ & -0.070 & $(0.049)$ \\
\hline
\end{tabular}

Significance levels: ${ }^{* * *} \mathrm{p}<0.01,{ }^{*} * \mathrm{p}<0.05,{ }^{*} \mathrm{p}<0.1$. Standard errors in parentheses.

Source: ZEW: Mannheim Innovation Panel. 
Figure 4.3: Lag-distributed Marginal Effects of Brand-related Investments

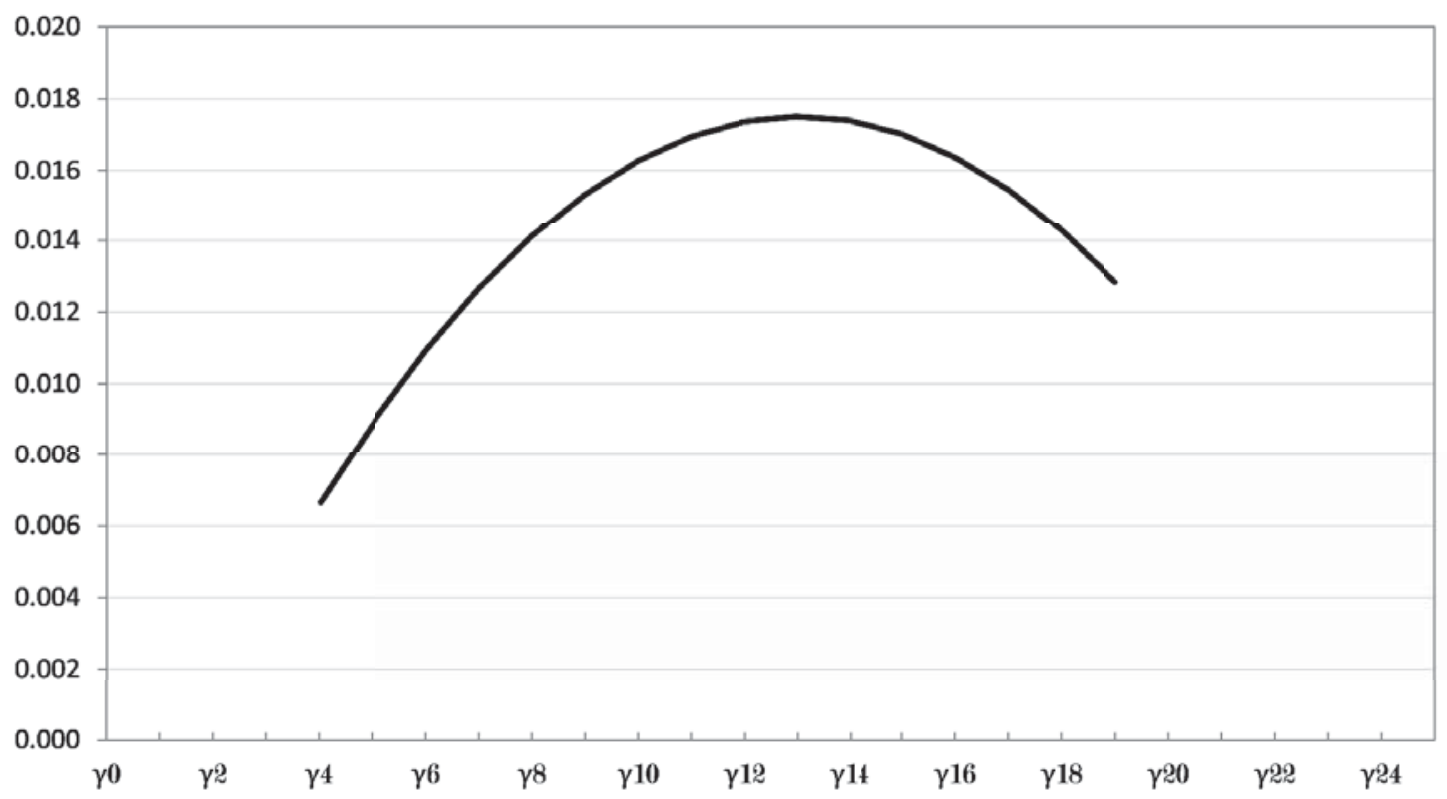

Notes: The graphical representation is based on Column (3) of Table 4.3.

The inverted U-shape relationship between the age of a brand-related investments and their impact on firm profitability illustrates the 'life cycle' of these investments. The economic value of brand-related investments are not significantly different from zero in the first few years, increase over a period of about 10 years, and decreases afterwards.

The impact of brand-related investments on a firm's profit margin is statistically significant. But to which extent do these investments contribute to firm profits? The coefficients of the estimated $\gamma$ 's identify directly, as already stressed, the marginal effects on firm profits. This allows us to calculate the profits of a firm that are related to its brand-related investments, proxied by its valid trademarks. Each brandrelated investment is thus weighted according to its age using the corresponding gamma coefficient. We take those coefficients that are not significant at the ten percent level as zero. We obtain for each firm a weighted portfolio of brand-related investments that represent the average marginal effect of this portfolio on firm profitability. Multiplication of firm sales with the weighted marginal effect yields a firm's profits that are related to its brand-related investments. The distribution of the contribution of brand-related investments to profits is highly skewed. The annual marginal effect of the median brand-related investments is 0.018 . The corresponding contribution of the median brand-related investments to firm profits is about EUR 273.000 per year. The contribution to firm profits is zero for a non-negligible group of $20 \%$ of trademarking firms and reaches values of more than 2.8 million Euros for the upper quartile of trademarking firms.

Our econometric results are robust against several modifications: (i) Relaxing the assumption about the functional form to a cubic polynomial leads to no substantial 
changes in the results. (ii) Another modification concerns the number of brandrelated investments, proxied by valid trademarks. The distribution of the size of trademark portfolios is highly skewed. Excluding the firms with the largest trademark portfolios has no effect, the results remain stable. (iii) Large firms might be more capable to establish valuable brands. Excluding firms with more than 500 employees does not affect the major results. The U-shape relationship is again confirmed, but the first years of the brand-related investment have a significantly negative effect on profitability. (iv) We consider only valid (living) trademarks as proxy for brand-related investments. The consideration of all registered trademarks, including non-valid ones, does not change the results.

\subsection{Conclusion}

Brand equity contributes to the financial performance of a firm in two ways: It affects revenues positively and decreases marketing costs. The successful development of brand equity requires, however, the investment of substantial marketing efforts and it is a priori unclear whether these investments pay off for an average firm.

This paper investigates the relationship between past brand-related investments and current financial performance for a representative sample of German firms. We make use of a panel from 2001 to 2010 that also contains many small and medium-sized firms. Most of these firms are not required to publish any data, which constitutes an important difference compared to other studies. Other studies that rely on publicly available firm level information most likely use a selective sample of large firms which are not representative for the economy. We are able to avoid this limitation.

We contribute to the literature by explaining a firm's profit margin with brandrelated investments. We use a standard model of profitability and proxy brandrelated investments by the flow of trademark registrations over a long period of thirty years. The flow of investments is not consolidated in a stock formulation but is used to estimate the contribution of brand-related investments within a distributed lag model. This is a major difference to most other studies which use a stock formulation. Our results support the view that continual investment is needed to maintain brand equity. Brand-related investments have a long-run impact on a firm's profit margin, but show no significant short-term impact. We find that the contribution of brand equity to profits is not only statistically significant but also economically. The median firm that conducts brand-related investments achieves a contribution of EUR 273.000 per year to its profits. 


\section{A Appendix}

\section{A.1 Definition of Variables}

Table 4.4: Variable Definitions

\begin{tabular}{ll}
\hline Variable & Definition \\
\hline Profit Margin & Profit before taxes on income as a percentage of turnover. \\
Trademarks & Dummy variable taking value 1, if firm has at least one registered \\
trademark. & Number of a firm's registered and still valid trademarks over the past \\
Trademark Stock & 30 years. This stock is equivalent to the Almon-Polynomial Term 1. \\
Firm size & Log of the number of employees. \\
Sales & $\begin{array}{l}\text { Sales capture the total turnover of a firm and are deflated (base year } \\
\text { is 2006). }\end{array}$ \\
Group & $\begin{array}{l}\text { Dummy variable taking value 1, if firm reports to be part of an enter- } \\
\text { prise group. }\end{array}$ \\
East & $\begin{array}{l}\text { Dummy variable taking value 1, if firm is located in East Germany } \\
\text { (the former territory of the GDR and West-Berlin). }\end{array}$ \\
Firm Age & $\begin{array}{l}\text { Log of the number of years since the enterprise was founded. Firms } \\
\text { observed in the year of their foundation are set to be 0.5 years old. }\end{array}$ \\
Dummy variable taking value 1, if firm reports a positive export value. \\
Exporter
\end{tabular}




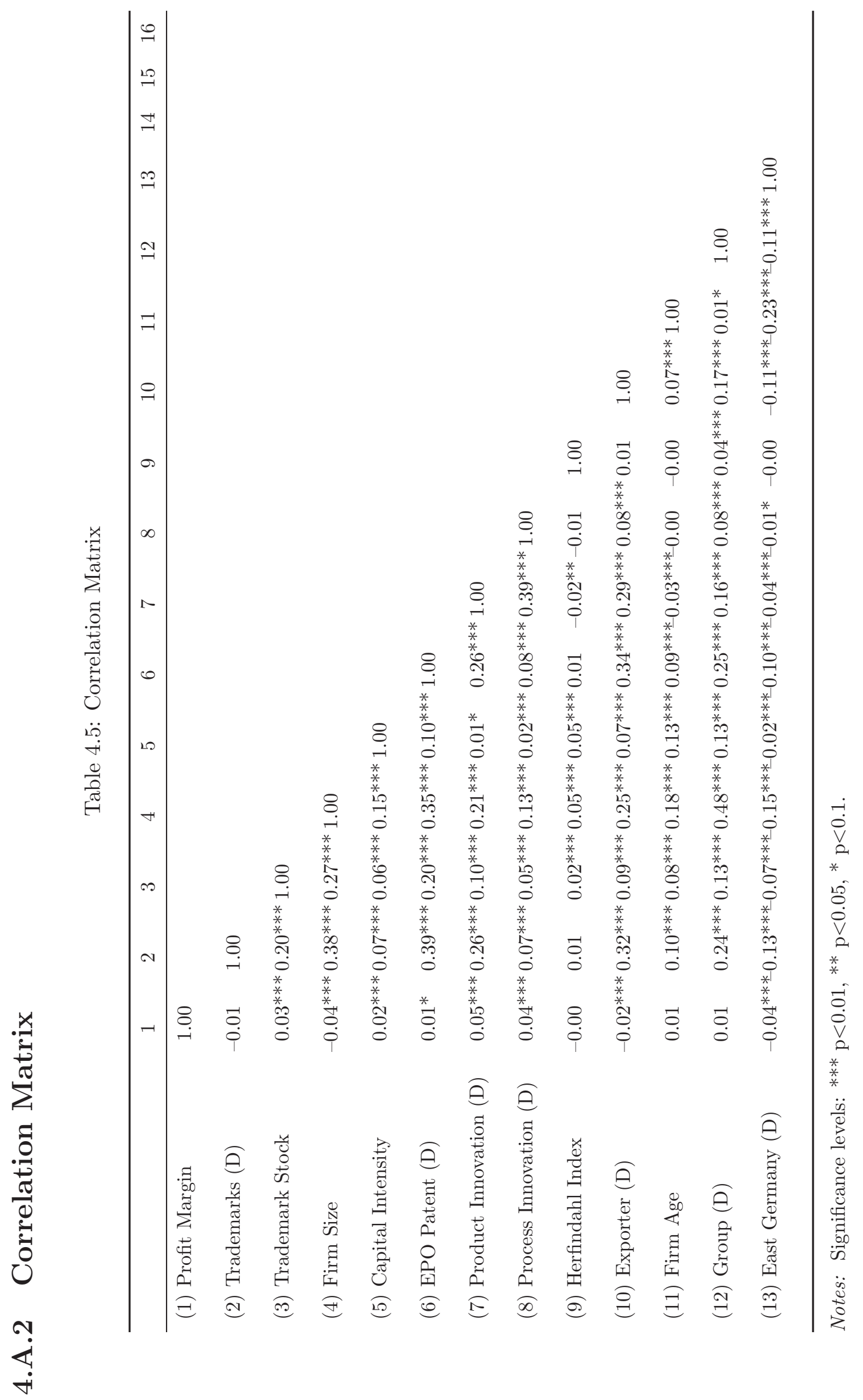


Table 4.6: Pooled vs. Panel Interval Regression

\begin{tabular}{|c|c|c|}
\hline & $\begin{array}{c}(1) \\
\text { Pooled Regression }\end{array}$ & $\begin{array}{c}(2) \\
\text { Panel Regression }\end{array}$ \\
\hline \multicolumn{3}{|l|}{ Brand-related Investments } \\
\hline Almon-Polynomial Term 1 & $\begin{array}{l}-0.013 \\
(0.009)\end{array}$ & $\begin{array}{l}-0.005 \\
(0.007)\end{array}$ \\
\hline Almon-Polynomial Term 2 & $\begin{array}{l}0.005^{* *} \\
(0.003)\end{array}$ & $\begin{array}{l}0.003^{* *} \\
(0.002)\end{array}$ \\
\hline Almon-Polynomial Term 3 & $\begin{array}{l}-0.000^{*} \\
(0.000)\end{array}$ & $\begin{array}{l}-0.000^{*} \\
(0.000)\end{array}$ \\
\hline Firm Size & $\begin{array}{l}-0.879^{* * *} \\
(0.075)\end{array}$ & $\begin{array}{l}-0.852^{* * *} \\
(0.105)\end{array}$ \\
\hline Firm Size Squared & $\begin{array}{l}0.066^{* * *} \\
(0.008)\end{array}$ & $\begin{array}{l}0.060^{* * * *} \\
(0.012)\end{array}$ \\
\hline Capital intensity & $\begin{array}{l}0.152^{* * *} \\
(0.025)\end{array}$ & $\begin{array}{c}0.024 \\
(0.025)\end{array}$ \\
\hline EPO Patent (D) & $\begin{array}{l}0.215^{* *} \\
(0.106)\end{array}$ & $\begin{array}{l}0.256^{*} \\
(0.154)\end{array}$ \\
\hline Product Innovation (D) & $\begin{array}{l}0.360^{* * *} \\
(0.080)\end{array}$ & $\begin{array}{l}0.294^{* * *} \\
(0.059)\end{array}$ \\
\hline Process Innovation (D) & $\begin{array}{l}0.132^{* * *} \\
(0.048)\end{array}$ & $\begin{array}{c}0.060^{*} \\
(0.034)\end{array}$ \\
\hline Herfindahl index & $\begin{array}{l}-2.052 \\
(2.432)\end{array}$ & $\begin{array}{c}0.733 \\
(2.231)\end{array}$ \\
\hline Exporter (D) & $\begin{array}{l}-0.038 \\
(0.080)\end{array}$ & $\begin{array}{c}0.077 \\
(0.092)\end{array}$ \\
\hline Firm Age & $\begin{array}{l}-0.011 \\
(0.031)\end{array}$ & $\begin{array}{l}0.182^{* * * *} \\
(0.044)\end{array}$ \\
\hline Group (D) & $\begin{array}{l}0.178^{* *} \\
(0.081)\end{array}$ & $\begin{array}{c}0.029 \\
(0.093)\end{array}$ \\
\hline East Germany (D) & $\begin{array}{l}-0.391^{* * *} \\
(0.072)\end{array}$ & $\begin{array}{l}-0.168 \\
(0.116)\end{array}$ \\
\hline W_Almon & 0.000 & 0.000 \\
\hline W_Industry & 0.000 & 0.000 \\
\hline W_Time & 0.000 & \\
\hline$\sigma \_u$ & & 5.304 \\
\hline$\sigma_{-} e$ & & 3.346 \\
\hline$\rho$ & & 0.715 \\
\hline Log-likelihood & $-75,523.78$ & $-66,846.96$ \\
\hline Observations & 38,431 & 38,431 \\
\hline
\end{tabular}

Significance levels: ${ }^{* * *} \mathrm{p}<0.01,{ }^{* *} \mathrm{p}<0.05,{ }^{*} \mathrm{p}<0.1$. Standard errors in parentheses.

Notes: Regression additionally includes three dummies indicating exporter, group, and capital intensity are missing. P-values of Wald tests on joint significance are indicated by "W.".

Source: ZEW: Mannheim Innovation Panel, surveys 2002-2011. 



\section{Chapter 5}

\section{Intangible Assets and Firm-Level Productivity ${ }^{10}$}

\subsection{Introduction}

Since the beginning of the nineties we have seen a rather weak growth performance in European countries compared to the US. The first response of the EU was the Lisbon strategy in 2000 which has recently been replaced by the new strategy for smart, sustainable and inclusive growth for high levels of employment, productivity and social cohesion, called Europe 2020. It is the EU's declared objective of this initiative to reap benefits from the knowledge economy. One important change that has taken place in the new initiative is the acknowledgement that knowledge capital is more than R\&D: it also includes other types of intangible capital such as design and licenses, computerized information, brand equity, firm-specific human capital, and organizational capital.

Measuring such intangible assets ${ }^{11}$ and their impacts is a challenging task due to data limitations. It is just recently that the literature has come up with new concepts of improving the measurement of intangible assets. At the macro level, Corrado et al. (2009) provided a consistent framework for the measurement of intangible assets and simultaneously confirmed the importance of intangible capital for economic growth. They found that in the United States $11.7 \%$ of GDP was invested in intangible assets in 2003. This share is much lower in European countries, but still high. It amounted to $10.1 \%$ of GDP in the United Kingdom (Marrano and Haskel, 2007), $7.6 \%$ in Germany (Crass et al., 2009), 8.7\% in France, $5.15 \%$ in Italy, and $5.2 \%$ in Spain (Hao et al., 2009). Using a growth accounting framework, Corrado et al. (2009) also showed that intangible investment stimulated labour productivity growth in the

\footnotetext{
${ }^{10}$ This chapter is co-written with Bettina Peters (ZEW, Zurich University). The authors are grateful for financial support that has been provided by the COINVEST project, www.coinvest.org.uk, funded by the European Commission Seventh Framework Programme, Theme 9, Socio-economic Science and Humanities, grant number 217512.

${ }^{11}$ We use the terms intangible assets and intangible capital interchangeably.
} 
United States by 0.84 percentage points. The growth enhancing effect is smaller in many European countries but still considerable: Labour productivity was boosted by 0.58 percentage points in the UK, 0.53 in Germany, 0.34 in Italy, and 0.19 in Spain.

The studies mentioned above have analysed the effect of intangible assets at the national or highly aggregated industry level. Our study, in contrast, takes a micro perspective and investigates how intangible assets affect productivity at the firmlevel. It is common knowledge that there is an extremely large heterogeneity in (labour) productivity at the firm level - even within the same industry. Productivity differences seem furthermore to be a persistent phenomenon (Doms and Bartelsman, 2000). These characteristics of firm-level productivity variation and persistence has aroused research into the underlying factors Syverson (2011). One argument that is put forward to explain these large productivity differences is the heterogeneity of firms' investments in intangible assets, which have been insufficiently taken into account in traditional productivity estimations.

There is a substantial literature studying productivity effects of R\&D, ICT and human capital in isolation (for recent surveys see Hall et al., 2010; de la Fuente, 2011; Abramovsky and Griffith, 2009). Less is known, however, about productivity effects of other types of intangible assets. We contribute to this strand of literature in two ways. First we simultaneously account for different types of intangibles in the spirit of Corrado et al. (2009). In addition to R\&D and human capital, we examine how and to what extent other intangible capital input factors like investments in design and licenses, brand capital and organizational capital can explain the variability of firm productivity. By simultaneously accounting for different types of intangibles we are better able to identify and isolate productivity effects of each category. Second, we provide evidence on whether complementarity or substitutability exists between investments in different kinds of intangible assets. In order to detect complementary or substitutive relationships we follow a recent test approach proposed by Carree et al. (2011). The empirical analysis is based on the Mannheim Innovation Panel (MIP), the German contribution to the European-wide Community Innovation Surveys (CIS). As a distinctive feature MIP provides information on expenditures related to intangible assets for German companies from the period 2006 to 2010 .

The outline of this paper is as follows. Section 5.2 summarises the main empirical firm-level evidence on productivity effects of intangibles that is beyond the consideration of R\&D. Our econometric framework is presented in section 5.3. The data set and variables are described in section 5.4. Stylized facts about the investments in intangible assets and productivity differences are presented in section 5.5. Results of the econometric analysis are given in section 5.6. The last section 5.7 draws some conclusions and discusses the main findings. 


\subsection{Productivity Effects of Intangible Assets}

Many firms spend a large amount on intangible assets such as R\&D, design, branding, organizational or human capital. As already pointed out, a major challenge in quantifying the productivity effects of such intangible assets roots in the problem of measuring them appropriately. Data for some of these components, like scientific R\&D, are well documented, internationally harmonized and comparable to a large extent. Other categories like organizational capital, however, are rather crudely measured so far. In addition, accounting rules for these components differ across accounting standards. Depending on the type of intangible asset,${ }^{12}$ they have to be capitalized if they fulfil certain criteria (e.g. development expenditures in IAS), firms can opt for capitalization (e.g. own produced fixed intangible assets in German accounting standard HGB) or they are not allowed to be capitalized and treated as expenses (e.g. research expenditures in IAS and HGB, own produced trademarks or goodwill in HGB).

In a recent study, (Marrocu et al., 2012) examine the impact of intangible capital on firms' productivity level in six European countries: France, Italy, Netherlands, Spain, Sweden and the United Kingdom. Their study relies on balance sheet information for the period 2002 to 2006 and thus intangible capital comprises only those intangible assets that have been capitalized. Based on a Cobb-Douglas production function approach they find a highly significant effect of intangible capital on productivity. The impact of intangible capital, however, turns out to be lower than that of physical capital. The estimated elasticity of about $0.04-0.06$ is only roughly half as large as that of physical capital. Moreover, they corroborate a productivityenhancing effect in all countries. The variation across countries turns out to be relatively large. The impact is more than three times larger in the UK (0.09) than in Spain (0.023).

The study by Bontempi and Mairesse (2014) goes beyond the impact of purely capitalized intangible assets. In comparing productivity effects of intangible relative to tangible capital, they differentiate between capitalized versus expensed intangible capital on the one hand and intellectual (mainly $R \& D$ and patents) versus customer intangible capital (mainly advertising, trademarks) on the other hand. Using data for Italian firms, their estimates also provide evidence that intangible capital has a stimulating effect on productivity. They find a strong positive relationship between intangible capital and productivity levels with an estimated output elasticity of about 0.025 whereas the nexus was much weaker in terms of productivity growth (estimated output elasticity of 0.012). In contrast to Marrocu et al. (2012) their results further show that intangible capital and its different components are at least as productive as tangible capital. Focussing on intangible components, they find

\footnotetext{
${ }^{12}$ The international accounting standard IAS defines an intangible asset as an "identifiable nonmonetary asset without physical substance".
} 
that intangible capital based on current expenses which involves a higher risk is less productivity-enhancing than capitalized intangible capital.

Both studies investigate the effect of intangible capital as a whole or in broad categories (intellectual versus consumer-related) without disentangling the effect of single intangible components. The most prominent component that has deserved a lot of attention in the literature is R\&D. At the micro level, the productivity-enhancing effect of R\&D is well documented. Starting with the seminal work by Griliches (1979), many studies have investigated the impact of $R \& D$ on productivity at the firm level. We refer to the recent survey by Hall et al. (2010) and the references cited therein. In a nutshell, they conclude that most studies show a significant positive private return to $R \& D$, ranging mostly between 20 to $30 \%$. The corresponding output elasticity of $\mathrm{R} \& \mathrm{D}$ ranges from 0.01 to 0.25 in most studies and is often centered around 0.08 .

Greenhalgh and Longland (2005) measure productivity effects of innovative capital through a set of indicators: In addition to R\&D expenditures they use patents and trademark registrations. They find for their sample of manufacturing firms that trademark activity is correlated with permanent productivity gains. Greenhalgh and Rogers (2012) also examine the role of trademark activity on productivity. Firms which apply for a trademark in the previous year are defined as trademark active. They find trademark activity leads to significantly higher productivity and improved productivity growth. Trademarking firms have between 10\% and 30\% significantly higher value added than non-trade markers.

Other components of intangible capital have attracted much less attention, again mainly because of difficulties in measurement. In the terminology of Corrado et al. (2009) one of these components is computerized information. At the firm-level, an increasing number of studies have investigated the effect of information technology (computer hardware and peripherals), communication technology (mainly broadband) or ICT in general on productivity. Recently, Software has been considered also (Sarbu, 2013). These studies provide empirical evidence of a positive and significant productivity effect of ICT in general (Bertschek and Kaiser, 2004; Hempell, 2005), IT (Brynjolfsson and Hitt, 1996; Bresnahan, 2002) and broadband (Grimes et al., 2012). The estimated output elasticity of ICT is in the 0.05 range (see Kretschmer et al., 2013) and has increased over time. This contradicts the Solow paradox, which stated that computers are everywhere but in the productivity statistics (Solow, 1987). See for instance the surveys by Kretschmer et al. (2013); Brynjolfsson and Hitt (2003); Bertschek (2003), or Draca et al. (2007). Brynjolfsson and Hitt (2003) found for example that over short horizons, estimated output contributions of computers are roughly equal to their costs. Over longer time horizons computerization is associated with an output contribution between two and five times as much as the short-run impact. Moreover, they emphasize that relatively large and time-consuming investments in complementary inputs, such as 
organizational capital, are required. Polder et al. (2009) extended the standard CDM framework that relates innovation input to innovation output and innovation output to productivity (see also Crépon et al., 1998). They include investment in ICT as an endogenous input into innovation output and analyse the combined implementation of product, process and/or organizational innovation on productivity. Data on organizational innovation are sourced from the Community Innovation Survey (CIS) for the Netherlands. Organizational innovation includes the introduction of new business practices, knowledge management systems, methods of workplace organization, and management of external relations. The introduction of an organizational innovation can be seen as a change in the organizational capital of a firm. Their findings indicate that in manufacturing the strongest productivity effects have been derived from organizational innovation. In services, the strongest productivity effect results from the combined use of process and organizational innovation. Furthermore, they show that organizational and product innovations are substitutes whereas organizational innovation and process innovation are complements. In a recent series of studies, Bloom, Sadun and Van Reenen have investigated the effect of various organizational and management practices on productivity (Bloom and van Reenen, 2007; Bloom et al., 2010, 2012). Bloom and van Reenen (2007) conducted a telephone survey of 732 medium-sized manufacturing firms in the United States, the United Kingdom, France, and Germany. Based on a five-point Likert scale of 18 practices which are grouped into the areas operations, monitoring, targets, and incentives, they derive a measure of overall managerial practice. They find better managerial practice to be strongly associated with higher firm-level productivity.

Another important component of intangible capital is firm-specific human capital, measured by training expenditures in the Framework of Corrado et al. (2009). The impact of training on firm productivity has been investigated by a relatively small number of empirical papers, with special attention being paid to the relationship of human capital and wages. The background for this is the (simplest) neoclassical view of a perfect competitive labour market where wages will be equal to the value of the marginal product of labour. Thus, wages can be used a direct measure of productivity. However, empirical studies listed below suggest that the productivity effect of training is higher than the wage effect and thus wages as direct productivity measures may underestimate the role of training. In our context it is important to note that a positive correlation of training and productivity is generally found. One example is the sector-level study of Dearden et al. (2006). They use a panel of British industries and confirm (based on a Cobb-Douglas production function) a statistically and economically significant impact of work-related training on productivity in the private sector: A one percent increase in training is associated with an increase in value added per hour of about 0.6 percent. Black and Lynch (1996) study the relationship of human capital investments in the form of employer provided training on business productivity. Using survey data on U.S. establishments with more than 
20 employees they estimate a Cobb-Douglas production function and find that the number of workers trained has no significant impact on productivity. However, the greater the proportion of time spent in formal off-the-job training, the higher the productivity in manufacturing firms. Black and Lynch (2001) find mixed evidence: raising the average educational level of workers increase productivity while training has no impact. Konings and Vanormelingen (2009) examined the effect of training on productivity and wages. They make use of firm-level panel data on various elements of training from annual reports of Belgian firms to simultaneously estimate a wage equation and a production function. They estimate a productivity premium for a trained worker of 23 percent and a wage premium of training that is roughly 12 percent. Thus, training enhances marginal productivity more than it increases the wage of the respective employee. Furthermore, they found that training has a slightly higher impact in services compared to manufacturing.

But so far only a very few papers have investigated the effect of different intangible components at the same time. Ballot et al. (2006) examined the effect of training and R\&D on productivity using firm-level data for France and Sweden. They found the effect of training to be larger than that of $\mathrm{R} \& \mathrm{D}$. The estimated average output (value added per employee) elasticity of training and R\&D amounts to 17.3 and 5.4 percent in France and 7.3 and 6.1 percent in Sweden, respectively. In addition, they corroborate a significant positive complementarity effect between training and R\&D. That is, the empirical results indicate that training (R\&D) has a larger positive impact on productivity if the firm has accumulated a higher stock of R\&D capital (human capital). In a recent study, Ramirez and Hachiya (2008) measured the contribution of intangibles to productivity growth of Japanese firms. They distinguish R\&D, advertising and firm-specific organizational capital. A special feature of their study is that firm-specific organizational capital growth is not directly measured but approximated by the estimated fixed effect of an annual growth equation. They conclude that firm-specific organizational capital is one of the most critical factors in determining the productivity growth and advertising is one of the most productive inputs.

Our study contributes to the literature by simultaneously investigating the productivity effects of a comprehensive set of intangible components similar to the ones proposed by Corrado et al. (2009). By simultaneously accounting for different types of intangibles, we are better able to identify and isolate productivity effects of each category. As explained in more detail in section 5.4, we include different measures for Innovative Capital, Human Capital, Branding Capital, as well as Organizational Capital. Furthermore, we investigate whether complementarity or substitutability exists between investments in different kinds of intangible assets. 


\subsection{Econometric Framework}

Most of the studies mentioned above have used a production function approach in general and a Cobb-Douglas production function in particular as their theoretical framework (see, for example, Mairesse and Sassenou, 1991). We follow this line of research and estimate in the first stage firm level Total Factor Productivity (TFP) and in the second stage the contribution of several intangible assets on TFP.

\section{First stage: Estimation of TFP}

The output of firm $i$ at time $t$ can be described by the Cobb-Douglas production function:

$$
Q_{i t}=A_{i t} L_{i t}^{\beta_{l}} K_{i t}^{\beta_{k}} M_{i t}^{\beta_{m}}
$$

where $Q_{i t}, M_{i t}$, and $K_{i t}$ denote firm $i^{\prime} s$ value of output, material, and physical capital and $L_{i t}$ denotes its labour input, measured as the number of employees. $A_{i t}$ is a measure of firm $i^{\prime} s$ level of efficiency, commonly referred to as Total Factor Productivity (TFP). The effect of $A_{i t}$ on $Q_{i t}$ is assumed to be Hicks-neutral, so TFP is additively separable from the other production factors. ${ }^{13}$

An alternative representation of equation (5.1), where small letters denote corresponding log values, constitutes a linear production function,

$$
q_{i t}=\beta_{0}+\beta_{l} l_{i t}+\beta_{k} k_{i t}+\beta_{m} m_{i t}+\omega_{i t}+\eta_{i t}
$$

where $\ln \left(A_{i t}\right)$ is now decomposed into three elements, $\beta_{0}, \omega_{i t}$, and $\eta_{i t}$. The first element, $\beta_{0}$, represents mean efficiency across all firms and $\omega_{i t}$ denotes the time- and firm-specific deviation from that mean, while $\eta_{i t}$ is a true error term that contains unobserved shocks and measurement errors. We assume that the firm-specific deviation from the mean efficiency is observable by the firm when it makes its investment decision, but not by the econometrician.

Since we are interested in analysing the influence of intangibles on productivity, we define the left hand side as output per employee and therefore as labour productivity:

$$
q_{i t}-l_{i t}=\beta_{0}+\left(\beta_{l}-1\right) l_{i t}+\beta_{k} k_{i t}+\beta_{m} m_{i t}+\omega_{i t}+\eta_{i t}
$$

With a little algebra, equation (5.3) becomes:

$$
q_{i t}-l_{i t}=\beta_{0}+\left(\beta_{l}+\beta_{k}+\beta_{m}-1\right) l_{i t}+\beta_{k}\left(k_{i t}-l_{i t}\right)+\beta_{m}\left(m_{i t}-l_{i t}\right)+\omega_{i t}+\eta_{i t}
$$

Equation (5.4) allows us to test for constant returns to scale. A labour coefficient significantly greater (smaller) than zero, suggests increasing (decreasing) returns

\footnotetext{
${ }^{13}$ For recent efforts of allowing for labour-augmenting biased technological change see Doraszelski and Jaumandreu (2014)
} 
to scale. In the case of constant returns to scale in all input factors, i.e. $\mu=$ $\beta_{l}+\beta_{k}+\beta_{m}=1$, the production function becomes:

$$
q_{i t}-l_{i t}=\beta_{0}+\beta_{k}\left(k_{i t}-l_{i t}\right)+\beta_{m}\left(m_{i t}-l_{i t}\right)+\omega_{i t}+\eta_{i t}
$$

Based on the estimates of equation (5.4), which will be explaned in more detail in section 5.6, total factor productivity is computed in the following way,

$$
\widehat{T F P}_{i t}=\left(q_{i t}-l_{i t}\right)-(\widehat{\mu}-1) l_{i t}-\widehat{\beta}_{k}\left(k_{i t}-l_{i t}\right)-\widehat{\beta_{m}}\left(m_{i t}-l_{i t}\right)
$$

\section{Second stage: The contribution of intangible assets to TFP}

The estimate for Total Factor Productivity $\widehat{T F P}_{i t}$ resulting from equation (6) is used in the second stage to evaluate the impact of intangible assets. The resulting regression looks as follows:

$$
\widehat{T F P}_{i t}=\gamma_{1} I C_{i t}+\gamma_{2} H C_{i t}+\gamma_{3} B C_{i t}+\gamma_{4} O C_{i t}+X_{i t}+\varepsilon_{i t}
$$

where IC denotes Innovative Capital, HC captures Human Capital, BC is Branding or Reputation Capital and OC stands for Organizational Capital. In addition to intangible capital, a set of control variables $X_{i t}$ is included. In the following section, we describe the data set and the measurement of the variables used in the econometric analysis.

\subsection{Data and Variables}

\subsubsection{Data}

Our study makes use of the Mannheim Innovation Panel (MIP). The MIP is the official German innovation survey. Since 1993 the survey has been conducted annually by the Centre for European Economic Research (ZEW), infas-Institut für Sozialforschung and ISI Fraunhofer Institute on behalf of the German Federal Ministry of Education and Research. Initially every fourth year and since 2005 every second year it is the German contribution to the European Community Innovation Survey (CIS), co-ordinated by Eurostat. The methodology and questionnaires are internationally harmonized across the countries. The survey is representative for all enterprises with at least five employees in German manufacturing and services. The sample is drawn as a stratified random sample, using industry (Nace 2-digit classification), firm size (eight size classes: 5-9, 10-19, 20-49, 50-99, 100-249, 250499, 500-999, 1000 and more) and region (East and West Germany) as stratification criteria. The survey is voluntary in Germany and each year between 5000 and 7000 enterprises in manufacturing and services respond to the survey and provide infor- 
mation on their innovation activities and some general firm characteristics such as sales, employment, exports, physical capital or investment. Primary respondents are general managers and heads of $\mathrm{R} \& \mathrm{D}$ departments or innovation management department. ${ }^{14}$ For a more detailed description of the dataset and the survey see Peters (2008), Aschhoff et al. (2013) and Peters and Rammer (2013). Since not all categories of intangible capital were asked for the whole period, we have to restrict the empirical analysis to the surveys 2007-2011 which cover the time period 20062010. All variables expressed in Euro values are deflated by industry-specific price indices published by the German statistical office. Our unbalanced panel consists of 6,231 firms with an average participation of 1.77 and 11,021 observations in total.

\subsubsection{Variables}

\section{Dependent Variable}

Since our panel is rather short and unbalanced, we use TFP in levels instead of TFP growth as our main dependent variable. As a robustness check, we furthermore study the impact of intangibles on labour productivity, which is defined as the logarithm of sales per employee.

\section{Traditional Factor Inputs}

The productivity equation controls for input variations in material and physical capital. Capital measures physical capital which is defined as tangible assets in book value per employee in year $\mathrm{t}$ (in log.). Information on tangible assets is directly inquired in the survey. Material is defined as material costs per employee in year $t$ (in log.). Material costs actually comprise expenditures for materials, intermediate inputs and energy (including ordered services). Both Capital and Material as well as the amount of investment in physical capital (Investment) are direct information from the MIP. Although productivity is measured in intensity form, Labour is additionally included in the set of explanatory variables. This specification allows us to test for the hypothesis of constant returns to scale which corresponds to a zero coefficient of Labour. Labour is measured as the number of employees excluding the number of R\&D employees (in logs). The latter correction is made to avoid double counting R\&D employees as part of Labour and as part of R\&D since a substantial proportion of the total R\&D expenditure consists of outlays for R\&D employees (see Cuneo and Mairesse 1995). Schankerman (1981) and Hall and Mairesse (1995) have shown that the estimated elasticity of $R \& D$ capital is downward biased if we do not correct for double counting. Admittedly, we would also have loved to correct Capital for investments in physical capital related to R\&D and Material for mate-

\footnotetext{
${ }^{14} 76 \%$ of the questionnaires are filled out by general managers and CEOs, $3 \%$ by head of R\&D departments. Another $14 \%$ of respondents belong to controlling and accounting.
} 
rial expenses related to $R \& D$ which are usually also included in $R \& D$ expenditure figures. Based on the data at hand, however, we are not able to correct Capital and Material to avoid double counting. However, figures of the R\&D surveys in Germany shows that the majority of $R \& D$ expenditure consists of labour costs $(60 \%)$ whereas investment make up only $7.8 \%$ and material costs $32.2 \%$.

\section{Intangible Inputs}

Which types of intangible assets do we account for? In our main regressions, we distinguish between three broad categories of intangibles: Innovative Capital (IC), Human Capital (HC), and Branding Capital (BC).

Innovative capital is proxied using three different intangible components: R\&D, design \& licenses, and the patent stock. R\&D is defined as the outlays for intramural and extramural R\&D activities in year t per employee (in log). Design \& Licenses (DL) captures innovative capital that is not related to R\&D activities but is related to the expenses for design, external knowledge, and product preparation in the course of innovation activities (per employee, in log.).

Due to data constraints, we cannot further separate these expenses. To avoid double counting we correct for marketing expenses and employee training and education programs related to the introduction of new products. ${ }^{15}$

In addition to the input oriented measures of innovative capital, we use the patent stock (P) as an output oriented variable for a firm's knowledge capital. The patent stock captures the accumulated number of granted patents at the European Patent Office (EPO). We use the perpetual inventory method to construct the patent stock applying a depreciation rate of $15 \%$. In order to account for the skewness of the patent stock we employ patent stock per employee on period $t-1$ as explanatory variable in the regression. Since some firms do not have patents, we additionally include a dummy variable indicating firms without patents.

Starting with the 2007 survey, the MIP also contains information on firm's total marketing expenditure which we employ to proxy reputation or branding capital. Marketing expenditure are defined as the sum of in-house and purchased advertising expenditure, conceptual design of marketing strategies, market and customer demand research and establishment of new distribution channels. Expenditure solely directed at sales and distribution activities are explicitly excluded. Marketing expenses are also scaled by using the number of employees and taking logs to account for the skewness of the distribution. Branding capital can be protected by trade-

\footnotetext{
${ }^{15}$ For both marketing and training expenditures for innovation, we use the average ratio of these expenses to overall innovation expenditure (IE) in industry $j$ from a prior wave to get expenditures for Design \& Licenses (DL) in the following way:
}

$$
D L=I E_{i j t}-\overline{\left(\frac{\text { marketing for innovation }}{I E}\right)_{j}} * I E_{i j t}-\overline{\left(\frac{\text { training for innovation }}{I E}\right)_{j}} * I E_{i j t}
$$


marks, which belong like patents to the family of intellectual property rights. The trademark stock of a firm might proxy two different types of intangibles: First, trademarks directly protect a firm's branding capital and thus the signs and names of its products and services so that it is not possible for other companies to use a confusingly similar mark (Economides, 1998). We use trademark data from the German Patent and Trade Mark Office (DPMA) for national protected trademarks as well as from the Office of Harmonization for the Internal Market (OHIM) for Community trademarks. We calculate the stock of registered trademarks per employee (in $\log$ ) and use the one-year lagged value as an additional variable for branding capital in the regression.

We follow Black and Lynch (2001) and use two indicators to proxy human capital. The first indicator accounts for the educational level of workers. The share of highskilled labour captures the proportion of employees with a tertiary degree. The second variable is the expenditure for internal and external professional development training. Information on both variables are directly taken from the survey. Note, as for marketing, training expenditure also includes costs for training activities that firms have occurred within innovation projects.

In addition to these three broad categories of intangibles, Corrado et al. (2009) suggested to account for computerized information and organizational capital as well. Unfortunately, the survey does not contain information on software investments. Regarding organizational capital, we do not have quantitative information but only qualitative measures. We use three dummy variables that indicate whether the firm has introduced new business processes (e.g. quality management systems, supply chain management systems, lean production, matrix organization), new methods of workplace organization (e.g. decentralization or centralization of decision making, job rotation, team work, basic realignment of departments), and new types of external relationships (e.g. alliances, cooperation agreements, outsourcing, customer relationship, supplier integration) in a three-year period t-2 to t. We interpret the introduction of one of these events as an improvement in organizational capital. Since this information is only available for the 2006, 2008 and 2010 cross-section, we leave out organizational capital in the main model but include it in a robustness analysis in section 5.6.

\section{Control Variables}

As additional control variables we include the export intensity and we use dummy variables indicating whether the company's headquarter is located in East Germany and whether a company is part of a group as well as time and industry dummies. A detailed definition of the variables employed in the empirical analysis is provided by Table 5.12 in the Appendix. 


\subsection{Stylized Facts on Firm-Level Investments in Intangibles}

This section presents some stylized facts on firm-level investment in intangibles and its relationship to productivity. Table 5.1 starts with reporting the proportion of firms that have invested in different types of intangible assets. It turns out that by far not all firms invest in all components of intangible assets.

Table 5.1: Proportion of Firms with Intangibles by Industries

\begin{tabular}{lccccccc}
\hline & $\begin{array}{c}\text { Full sample } \\
\text { Mean }\end{array}$ & $\begin{array}{c}\text { O-M } \\
\text { Mean }\end{array}$ & $\begin{array}{c}\text { LT-M } \\
\text { Mean }\end{array}$ & $\begin{array}{c}\text { MT-M } \\
\text { Mean }\end{array}$ & $\begin{array}{c}\text { HT-M } \\
\text { Mean }\end{array}$ & $\begin{array}{c}\text { KI-S } \\
\text { Mean }\end{array}$ & $\begin{array}{c}\text { LKI-S } \\
\text { Mean }\end{array}$ \\
\hline Innovative Capital & & & & & & & \\
$\quad$ R\&D & 0.42 & 0.11 & 0.35 & 0.59 & 0.81 & 0.36 & 0.15 \\
$\quad$ Design \& Licenses & 0.36 & 0.20 & 0.33 & 0.46 & 0.47 & 0.33 & 0.23 \\
$\quad$ Patent Stock & 0.18 & 0.06 & 0.12 & 0.35 & 0.43 & 0.06 & 0.04 \\
Human Capital & & & & & & & \\
$\quad$ Training & 0.88 & 0.89 & 0.78 & 0.89 & 0.93 & 0.88 & 0.89 \\
$\quad$ High Skilled Labour & 0.88 & 0.83 & 0.82 & 0.92 & 0.95 & 0.90 & 0.83 \\
Branding Capital & & & & & & & 0.83 \\
$\quad$ Marketing & 0.82 & 0.72 & 0.82 & 0.83 & 0.91 & 0.83 & 0.80 \\
$\quad$ Trademark Stock & 0.37 & 0.24 & 0.40 & 0.44 & 0.60 & 0.30 & 0.23 \\
Organizational Capital & & & & & & & 0.34 \\
$\quad$ Business Process & 0.39 & 0.26 & 0.31 & 0.44 & 0.54 & 0.41 & 0.31 \\
$\quad$ Labour Organization & 0.36 & 0.28 & 0.33 & 0.38 & 0.42 & 0.38 & 0.31 \\
$\quad$ Relation Management & 0.25 & 0.21 & 0.18 & 0.25 & 0.36 & 0.28 & 0.20 \\
\hline Observations & 11,021 & 766 & 1,714 & 3,198 & 943 & 2,941 & 1,459 \\
\hline
\end{tabular}

Notes: LT-M, MT-M, and HT-M denote low-tech manufacturing (including energy and construction), medium-tech manufacturing, and high-tech manufacturing. KI-S denotes knowledgeintensive and LKI-S low-knowledge-intensive services.

Source: ZEW: Mannheim Innovation Panel, surveys 2007-2011.

Regarding innovative capital, for instance, only about 42 percent of the firms in our sample report positive expenditures in $\mathrm{R} \& \mathrm{D}$ and only 18 percent have at least one granted patent at the European Patent Office (EPO). Around 36 percent report positive expenditures for Design \& Licenses. Much more common are investments in branding and human capital. About 82 percent of the companies invest in their reputation by spending in marketing activities. However, only 37 percent of the firms in the sample protect their branding capital by means of a registered Community or German trademark. The most common investment in intangibles relates to human capital. About 88 percent of the firms employ high skilled employees. This is further enhanced through investment in professional training by 88 percent of the firms in our sample. In contrast to investment in branding and human capital, firms invest less often in the third type of economic competences (Corrado et al., 2009), i.g. less frequently in organizational capital. Around one third of the companies invested in business processes (39 percent) and new methods of workplace organization (36 percent) and about one quarter in new external relations (25 percent). We further- 
more find that many firms have more than one type of intangible capital. Using the three broad categories $\mathrm{IC}, \mathrm{BC}, \mathrm{HC}$, we find that only a very small proportion of firms $(1.8 \%)$ do not invest in intangibles at all. About $11 \%$ of the firms invest in one type of intangibles. $35.8 \%$ of the firms invest in two types and more than half of the firms have all three types of intangibles (51.3\%). For the 2006, 2008, 2010 subsample we even find that one quarter of firms $(25.4 \%)$ have invested in all four types of intangibles (IC, BC, HC, OC). The correlation matrix in Appendix 5.14 provides evidence on the pairwise correlation of the usage of the various types of intangible assets. Highest correlation is found for R\&D and Design \& Licenses, R\&D and Patents, and Patents and Trademarks.

Table 5.1 furthermore provides an industry breakdown for six broad industry categories. As expected, the proportion of firms engaged in Innovative Capital is highest in high-tech manufacturing, followed by medium-tech manufacturing and knowledgeintensive service industries. The heterogeneity across sectors is large for $R \& D$ and patents, but much smaller for Design \& Licenses. The table reveals a clear ranking: Except for patents and trademarks, we find the share of firms having invested in intangibles to be highest in high-tech manufacturing, followed by medium-tech manufacturing and knowledge intensive service. For patents and trademarks, shares are also highest in high-tech manufacturing and medium-tech manufacturing but followed by low-tech manufacturing.

Table 5.2 furthermore reports quantitative measures on intangible assets. On average firms spend 2.87 thousand Euro per employee on R\&D and 2.1 thousand Euro on Design \& Licenses. Marketing expenditures are in between, amounting to 1.83 thousand Euro per employee. On average, less is spent on training activities (0.5 thousand Euro per employee).

The median of labour productivity amounts to 125 thousand Euro while the mean productivity is much higher with 203 thousand Euro. The per-employee level statistics suggest considerable departures from normality: the means are almost always larger than the corresponding medians.

As already mentioned, in the econometric analyse we use Labour which is corrected for R\&D employees to avoid double counting. This correction affects all per capita variables. While column (2) reports the mean values using the total number of employees in the denominator, column (6) additionally provides mean values using the corrected labour measure which are used in the empirical regression. As the denominator remained the same through the correction or became smaller, we see higher average values. This is particularly true for R\&D. Since a considerable proportion of firms do not invest in intangible assets, column (7) provides the average intangible capital per employee for those firms that invest in the respective intangibles. Investing firms spend the highest amounts into R\&D and Design \& Licenses, followed by Marketing. The median value of zero for all components of innovative capital and for the trademark stock point to the fact that less than half of the firms 
Table 5.2: Descriptive Statistics of Main Variables

\begin{tabular}{|c|c|c|c|c|c|c|c|}
\hline & $\begin{array}{c}(1) \\
\text { Median }\end{array}$ & $\begin{array}{c}(2) \\
\text { Mean }\end{array}$ & $\begin{array}{l}(3) \\
\text { SD }\end{array}$ & $\begin{array}{l}(4) \\
\text { Min }\end{array}$ & $\begin{array}{l}(5) \\
\text { Max }\end{array}$ & $\begin{array}{c}(6) \\
\text { Mean cL }\end{array}$ & $\begin{array}{c}(7) \\
\text { Mean IC }\end{array}$ \\
\hline \multicolumn{8}{|l|}{ Productivity } \\
\hline Productivity & 124.93 & 202.95 & 329.71 & 1.67 & 6990.9 & 216.90 & - \\
\hline \multicolumn{8}{|l|}{ Traditional Inputs } \\
\hline Capital & 26.35 & 129.52 & 452.80 & 0.049 & 14696.4 & 134.69 & - \\
\hline Labour & 53.00 & 872.91 & 6260.66 & 1 & 174773 & 825.00 & \\
\hline Material & 45.82 & 102.49 & 224.78 & 0.048 & 4944.6 & 107.56 & - \\
\hline \multicolumn{8}{|l|}{ Innovative Capital } \\
\hline R\&D & 0.00 & 2.87 & 8.74 & 0 & 290.3 & 5.08 & 12.15 \\
\hline Design \& Licenses & 0.00 & 1.21 & 9.80 & 0 & 921.6 & 1.52 & 4.24 \\
\hline Patent Stock & 0.00 & 0.00 & 0.03 & 0 & 1.65 & 0.01 & 0.05 \\
\hline \multicolumn{8}{|l|}{ Human Capital } \\
\hline Training & 0.25 & 0.50 & 0.86 & 0 & 24.7 & 0.58 & 0.66 \\
\hline High Skilled Labour * & 0.10 & 0.20 & 0.23 & 0 & 1 & 0.20 & 0.23 \\
\hline \multicolumn{8}{|l|}{ Branding Capital } \\
\hline Marketing & 0.33 & 1.83 & 6.36 & 0 & 200.6 & 2.07 & 2.51 \\
\hline Trademark Stock & 0.00 & 0.03 & 0.12 & 0 & 4 & 0.04 & 0.10 \\
\hline
\end{tabular}

Notes: The Table shows raw values in thousands of Euros. This is for the purposes of transparency only; the logarithmized variables are included in the models. The only exceptions are High Skilled Labour, which is a proportion between 0 and 1 and Labour which is measured in number of employees. Patents and Trademarks are measured as stocks per employee. Column (6) provides the sample means using the corrected labour measure as denominator in the per capita calculations and column (7) the truncated mean for firms with non-zero intangible capital.

Source: ZEW: Mannheim Innovation Panel, surveys 2007-2011.

invest in those intangible assets.

Do firms that invest in intangible assets differ in productivity? The descriptive statistics of Table 5.3 and mean difference tests support this view. For each category we find average labour productivity to be higher in firms that have invested in this type of intangible capital than in non-investing firms. The mean differences are in each case statistically significant. Firms that invest a disproportionately large amount in the respective intangible asset (i.e. above the mean), have an even higher average productivity. Interestingly, the only exception are the intellectual property rights, patents and trademarks for which we find productivity some what smaller in high-investing firms than in low-investing firms. The observed productivity differences between investors and non-investors might be driven by other observed or unobserved individual characteristics. Therefore, we use econometric techniques to analyse whether and to what extent this result holds in section 5.6. 
Table 5.3: Differences in Firm Productivity by Intangible Assets

\begin{tabular}{lccc}
\hline & Non-Investors & Investors & High investing firms \\
\hline Innovative Capital & & & \\
$\quad$ R\&D & 196.5 & $245.4^{* * *}$ & 302.8 \\
$\quad$ Design \& Licenses & 199.2 & $248.7^{* * *}$ & 282.8 \\
$\quad$ Patent Stock & 200.4 & $290.5^{* * *}$ & 279.1 \\
Human Capital & & & \\
$\quad$ Training & 151.0 & $226.2^{* * *}$ & 279.2 \\
$\quad$ High Skilled Labour & 143.0 & $226.7^{* * *}$ & 255.3 \\
Branding Capital & & & \\
$\quad$ Marketing & 188.4 & $223.0^{* * *}$ & 278.4 \\
$\quad$ Trademark Stock & 176.9 & $286.5^{* * *}$ & 284.8 \\
$\quad$ Organizational Capital & & & \\
$\quad$ Business Process & 199.0 & $225.4^{* * *}$ & \\
$\quad$ Labour Organization & 199.3 & $227.2^{* * *}$ & \\
$\quad$ Relation Management & 197.4 & $244.4^{* * *}$ & \\
\hline
\end{tabular}

\subsection{Econometric Results}

\subsubsection{Estimation Method}

In order to estimate the production function we have used various parametric and non-parametric econometric estimation methods. The empirical results presented below are based on our preferred approach of Olley and Pakes (1996). This approach solves both the endogeneity problem due to simultaneity of input and output decision and the selection problem that arises in the estimation of production functions. The endogeneity problem arises since the input factors are chosen by the firm and the firm has knowledge (at least to some extent) of its productivity shock when making these input choices. As a result, the firm's input choices will likely be correlated with its productivity (Marschak and Andrews, 1944). This implies that the input factors are correlated with the error term of the productivity equation. In this case, OLS is an inappropriate estimation method as it delivers inconsistent estimates. The variable inputs like labour and materials are expected to have an upward bias and the coefficients associated with quasi-fixed inputs like capital are expected to be biased downwards (Olley and Pakes, 1996). The method by Olley and Pakes (1996) solves the simultaneity issue by using the observable investment decision of the firm to proxy for unobserved productivity shocks in a control function approach.

The empirical analysis below is conducted in four steps. In section 5.6 .2 we focus on the effect of innovative, human and branding capital on productivity. Section 5.6.3 is devoted to some robustness checks regarding the estimation method and the measurement of intangible capital and productivity. In section 5.6.4 we additionally explore the role organizational capital plays for productivity. Finally, in section 5.6.5 we investigate whether investments in different kinds of intangible assets are complements or substitutes. 


\subsubsection{Effect of Intangibles on Productivity}

Table 5.4 provides the estimation results of equations (5.4) and (5.7), the first and second stage of our estimation procedure. Column (1) presents the estimates of a production function using solely the traditional input factors whereas the estimates in Column (2) additionally account for a set of control variables. Physical Capital and Material turn out to be highly significant with an estimated output elasticity of about 0.13 and 0.38 . The significantly positive coefficient of labour in Column (1) becomes significantly negative after including the controls indicating slightly decreasing returns to scale. The control variables further show that the productivity level is (still) lower in East Germany (the former GDR), that a firm which belongs to a group has synergy advantages, and that a higher export intensity is related to higher productivity levels.

In the second stage, TFP (Total Factor Productivity) is regressed on various components of intangible assets. ${ }^{16}$ We first examine separately the three broad intangible asset categories. We restrict the specification to the three components of Innovative Capital in Column (3), to those of Human Capital in Column (4), and to the components of Branding Capital in Column (5). Finally, all intangible asset components are jointly investigated in Column (6). It turns out that all components of Innovative Capital in Column (3), namely R\&D, Design \& Licenses, and Patent Stock, are highly significant in explaining TFP levels in German firms. The productivityenhancing effect of $R \& D$ is in line with many other empirical studies (Hall et al., 2010). Moreover, our findings show that also non-R\&D-related investment in innovative capital like Design \& Licenses are conducive to productivity. Note that we cannot directly compare the magnitude of the effect of tangible capital and intangible components since the latter are proxied by expenses. Column (4) shows that both components of Human Capital, Training and High Skilled Labour, also significantly raise productivity. The same is true for both components of Branding Capital in Column (5). Marketing and Trademark Stocks have a positive and seizable effect on TFP.

It is interesting to note that all coefficients of intangible capital get considerably smaller, when including the other types of intangibles, shown in Column (6). This reflects an omitted variable bias problem in Column (3) to (5). As the omitted variable bias formula states, positively correlated variables (like the intangible assets in our sample) that are left out in the regression cause an overestimation of the effect of included variables. The estimated effect for R\&D is, for instance, overestimated by $80 \%$ while R\&D and Design and Licenses are still significant the effect of the Patent Stock is no longer significant in the joint regression. This is an important message

\footnotetext{
${ }^{16}$ Many companies report no investment for some or all intangible assets. In order to deal it, we replace the log values with a constant (here: zero) and additionally add dummy variables for non-investing observations. In this way, the estimated output elasticity is unaffected by the choice about the constant.
} 
Table 5.4: Effect of Intangibles on Firm-Level Productivity (TFP)

\begin{tabular}{|c|c|c|c|c|c|c|}
\hline & $\begin{array}{c}(1) \\
\text { 1st stage }\end{array}$ & $\begin{array}{c}(2) \\
\text { 1st stage }\end{array}$ & $\begin{array}{c}(3) \\
\text { 2nd stage }\end{array}$ & $\begin{array}{c}(4) \\
\text { 2nd stage }\end{array}$ & $\begin{array}{c}(5) \\
\text { 2nd stage }\end{array}$ & $\begin{array}{c}(6) \\
\text { 2nd stage }\end{array}$ \\
\hline Capital & $\begin{array}{l}0.097^{* * *} \\
(0.022)\end{array}$ & $\begin{array}{l}0.131^{* * *} \\
(0.038)\end{array}$ & & & & \\
\hline Labour & $\begin{array}{l}0.019^{* * *} \\
(0.003)\end{array}$ & $\begin{array}{l}-0.012^{* * *} \\
(0.004)\end{array}$ & & & & \\
\hline Material & $\begin{array}{l}0.391^{* * * *} \\
(0.007)\end{array}$ & $\begin{array}{l}0.378^{* * *} \\
(0.007)\end{array}$ & & & & \\
\hline \multicolumn{7}{|l|}{ Innovative Capital } \\
\hline $\mathrm{R} \& \mathrm{D}$ & & & $\begin{array}{l}0.056^{* * *} \\
(0.004)\end{array}$ & & & $\begin{array}{l}0.031^{* * *} \\
(0.005)\end{array}$ \\
\hline Design \& Licenses & & & $\begin{array}{l}0.008^{* * *} \\
(0.003)\end{array}$ & & & $\begin{array}{c}0.005^{*} \\
(0.003)\end{array}$ \\
\hline Patent Stock & & & $\begin{array}{l}0.015^{* * *} \\
(0.005)\end{array}$ & & & $\begin{array}{c}0.005 \\
(0.005)\end{array}$ \\
\hline \multicolumn{7}{|l|}{ Human Capital } \\
\hline Training & & & & $\begin{array}{l}0.061^{* * *} \\
(0.004)\end{array}$ & & $\begin{array}{l}0.039 * * * \\
(0.005)\end{array}$ \\
\hline High Skilled Labour & & & & $\begin{array}{l}0.350^{* * *} \\
(0.026)\end{array}$ & & $\begin{array}{l}0.266^{* * *} \\
(0.026)\end{array}$ \\
\hline \multicolumn{7}{|l|}{ Branding Capital } \\
\hline Marketing & & & & & $\begin{array}{l}0.047^{* * *} \\
(0.003)\end{array}$ & $\begin{array}{l}0.030^{* * *} \\
(0.003)\end{array}$ \\
\hline Trademark Stock & & & & & $\begin{array}{l}0.032^{* * *} \\
(0.005)\end{array}$ & $\begin{array}{l}0.022^{* * *} \\
(0.005)\end{array}$ \\
\hline \multicolumn{7}{|l|}{ Controls } \\
\hline East Germany & & $\begin{array}{l}-0.156^{* * *} \\
(0.010)\end{array}$ & $\begin{array}{c}-0.007 \\
(0.010)\end{array}$ & $\begin{array}{c}-0.014 \\
(0.010)\end{array}$ & $\begin{array}{c}0.018^{*} \\
(0.010)\end{array}$ & $\begin{array}{c}-0.006 \\
(0.010)\end{array}$ \\
\hline Group & & $\begin{array}{l}0.147^{* * *} \\
(0.013)\end{array}$ & $\begin{array}{c}-0.020^{*} \\
(0.011)\end{array}$ & $\begin{array}{l}-0.029^{* * *} \\
(0.010)\end{array}$ & $\begin{array}{c}-0.020^{*} \\
(0.011)\end{array}$ & $\begin{array}{l}-0.034^{* * *} \\
(0.011)\end{array}$ \\
\hline Export & & $\begin{array}{l}0.160^{* * *} \\
(0.024)\end{array}$ & $\begin{array}{l}-0.073^{* * *} \\
(0.020)\end{array}$ & $\begin{array}{c}-0.039^{* *} \\
(0.019)\end{array}$ & $\begin{array}{c}-0.039 * * \\
(0.019)\end{array}$ & $\begin{array}{l}-0.084^{* * *} \\
(0.020)\end{array}$ \\
\hline W_Time & & 0.022 & 0.824 & 0.967 & 0.000 & 0.000 \\
\hline W_Industry & & 0.000 & 0.000 & 0.000 & 0.000 & 0.000 \\
\hline Adjusted R2̂ & 0.633 & 0.702 & 0.026 & 0.044 & 0.035 & 0.066 \\
\hline Observations & 11,021 & 11,021 & 11,021 & 11,021 & 11,021 & 11,021 \\
\hline
\end{tabular}

Notes: Significance levels: ${ }^{* * *} \mathrm{p}<0.01,{ }^{*} \mathrm{p}<0.05,{ }^{*} \mathrm{p}<0.1$. Standard errors in parentheses. Estimation method: Olley and Pakes (1996). The number of observations refers to the first stage of the OP regression. Due to the time structure, 5,453 observations remain for the non-linear regression of the second stage of the OP approach. Column (1) and (2) provide bootstrapped standard errors in parentheses. The TFP regression additionally includes six dummies indicating R\&D, Design \& Licenses, Patent Stock, Firm-specific Training, Marketing, and Trademark Stock is zero. Column (3) to (6) provide robust standard errors in parentheses.

in itself, as it implies that output elasticities of individual intangible components are overestimated, when not all inputs are properly considered. Admittedly, this restriction applies (to a lesser extent) also to our estimates because intangible assets like software and databases or organizational capital are not considered due to data limitations. However, the extent of the bias in our more complete set of intangible assets should be rather limited. To sum up, our results strikingly show that except 
for Patent Stock, all intangible components are productivity-enhancing.

We also aim at shedding light on the question of whether the impact of intangibles differ across industries. In order to do so, we split the sample into various subsamples. Our results show some interesting findings. ${ }^{17}$ First, it is corroborated that human capital has a stimulating effect on productivity across all industries. Interestingly, the average effect is stronger in more labour-intensive service industries compared manufacturing industries. Likewise, branding capital turns out to be positive related to productivity in all manufacturing and service industries. Rather puzzling is the finding that trademarks do not significantly enter the productivity equation, neither for medium-tech and high-tech, nor for knowledge-intensive firms. Trademarks are however productivity enhancing in industries of low level of technological intensity (low-tech manufacturing and low-knowledge-intensive services). The impact of marketing expenditure is highly significant across all industries and of similar magnitude in all industries except for medium-tech manufacturing. Third, the largest variations across industries stick out for our proxies measuring different aspects of innovative capital. Our results are sensible in that we find that R\&D significantly boosts productivity in all manufacturing industries and knowledgeintensive services. We find a long-term effect of innovative capital in a sense that accumulated granted patents stimulate current productivity in high-tech manufacturing as well as in knowledge-intensive and low-knowledge-intensive services. In low-knowledge intensive services such as transport or wholesale the picture that emerges is more obscure. Investments in $R \& D$ do not lead to productivity increases per se but only if firms have successfully transformed R\&D investments into granted patents. Our results further provide interesting insights into the role of design and licenses. We find them to largely matter only in knowledge-intensive services but not in manufacturing industries.

\subsubsection{Robustness Checks}

\section{Several Productivity Estimation Methods}

The econometric literature provides several approaches to deal with the endogeneity issue in the context of production function estimation. Eberhardt and Helmers (2010) emphasize that the most popular estimators for Cobb-Douglas production functions are conceptually quite similar but that in practice the choice of the estimation method might considerably influence the empirical results. We examine the influence of the estimation method on our empirical results by comparing alternative parametric (OLS, FE) and non-parametric (OP, LP) estimation methods. Table 5.5 provides the results of the second stage, the regression of TFP on our set of intangible assets.

\footnotetext{
${ }^{17}$ Detailed results are presented in Table 5.16 and Table 5.17 in the Appendix.
} 
Table 5.5: Robustness Check: Parametric and Non-Parametric Estimation Methods

\begin{tabular}{|c|c|c|c|c|}
\hline & $\begin{array}{c}(1) \\
\text { OLS }\end{array}$ & $\begin{array}{l}(2) \\
\mathrm{FE}\end{array}$ & $\begin{array}{l}(3) \\
\text { LP }\end{array}$ & $\begin{array}{l}(4) \\
\mathrm{OP}\end{array}$ \\
\hline \multicolumn{5}{|l|}{ Innovative Capital } \\
\hline $\mathrm{R} \& \mathrm{D}$ & $0.033^{* * *}(0.005)$ & $0.028 * * *(0.006)$ & $0.045^{* * *}(0.005)$ & $0.031^{* * *}(0.005)$ \\
\hline Design \& Licenses & $0.005^{*} \quad(0.003)$ & $0.007^{* *}(0.003)$ & $0.010^{* * *}(0.003)$ & $0.005^{*} \quad(0.003)$ \\
\hline Patent Stock & $0.005 \quad(0.005)$ & $-0.004 \quad(0.007)$ & $-0.008 \quad(0.006)$ & $(0.005)$ \\
\hline \multicolumn{5}{|l|}{ Human Capital } \\
\hline Training & $0.041^{* * *}(0.005)$ & $0.082^{* * *}(0.007)$ & $0.068 * * *(0.005)$ & $0.039 * * *(0.005)$ \\
\hline High Skilled Labour & $0.255^{* * *}(0.029)$ & $0.380 * * *(0.037)$ & $0.288 * * *(0.031)$ & $0.266^{* * *}(0.026)$ \\
\hline \multicolumn{5}{|l|}{ Branding Capital } \\
\hline Marketing & $0.030 * * *(0.003)$ & $0.050 * * *(0.004)$ & $0.051^{* * *}(0.004)$ & $0.030 * * *(0.003)$ \\
\hline Trademark Stock & $0.020 * * *(0.005)$ & $0.032^{* * *}(0.006)$ & $0.019 * * *(0.006)$ & $0.022^{* * *}(0.005)$ \\
\hline Controls & yes & yes & yes & yes \\
\hline W_Time & 0.000 & 0.000 & 0.000 & 0.000 \\
\hline W_Industry & 0.000 & 0.000 & 0.000 & 0.000 \\
\hline Adjusted R̂2 & 0.249 & 0.361 & 0.212 & 0.066 \\
\hline Observations & 11,021 & 7,392 & 11,021 & 11,021 \\
\hline
\end{tabular}

Notes: Significance levels: $* * * \mathrm{p}<0.01,{ }^{*} * \mathrm{p}<0.05,{ }^{*} \mathrm{p}<0.1$. Standard errors in parentheses. Estimation method: OLS, FE (fixed effects), LP (Levinsohn and Petrin, 2003) and OP (Olley and Pakes, 1996). Regression additionally includes the standard control variables (East, Group, and Export) and six dummies indicating R\&D, Design \& Licenses, Patent Stock, Firm-specific Training, Marketing, and Trademark Stock is zero.

The OLS estimates are presented in Column (1). As already stressed, they are likely to be biased. One traditional (parametric) solution to the endogeneity problem is fixed effects (FE) estimation which makes explicit use of firm panel data. The fundamental assumption behind this model is that unobserved productivity is constant over time. As reported in other studies, we got unreasonable large coefficients for labour in the FE estimates and therefore follow the suggestions by Mairesse and Griliches (1998) and assume constant return to scale. The FE estimates in Column (2) of Table 5.5 confirm a strong significant impact of R\&D, Design \& Licenses, Human and Brand Capital on productivity. However the effect of Human and Brand Capital is larger in the FE estimation.

An alternative solution to FE and OP is provided by Levinsohn and Petrin (2003), who build on the Olley and Pakes (1996) approach. Levinsohn and Petrin (2003) (LP) propose the use of intermediate inputs instead of investment to back out productivity shocks observed by the firm. Column (3) shows that LP also provides qualitatively the same results as $\mathrm{OP}$ and FE. Comparing LP and OP, we generally find somewhat larger effects of intangibles using LP, except for Trademarks. Qualitatively, FE yield the same results as OP and OLS.

Overall, the coefficient of $R \& D$ is largest in the LP estimation. The same is true for Design \& Licenses, whereas the effect of Training and High Skilled Labour is largest in the FE estimation. But all in all, accounting for endogeneity by using the OP estimation method provides very similar results to the alternative estimation 
methods. The estimated productivity effects of intangible assets remain quite stable and, with the exception of the Patent Stock, highly significant.

\section{Labour Productivity vs. Total Factor Productivity}

Our estimation approach is sequential and consists of two stages: In the first stage, firm-level TFP is estimated and the second stage investigates the impact of intangible assets on TFP. An alternative widely used approach uses a standard CobbDouglas production function augmented with intangible capital stocks (Griliches, 1979; Hall and Mairesse, 2006). The augmented production function is estimated in one stage.

In the case of our empirical setting, this results into the following equation:

$$
\begin{array}{r}
q_{i t}-l_{i t}=\beta_{0}+(\mu-1) l_{i t}+\beta_{k}\left(k_{i t}-l_{i t}\right)+\beta_{m}\left(m_{i t}-l_{i t}\right) \\
+\gamma_{1}\left(i c_{i t}-l_{i t}\right)+\gamma_{2}\left(h c_{i t}-l_{i t}\right)+\gamma_{3}\left(b c_{i t}-l_{i t}\right)+\gamma_{4}\left(o c_{i t}-l_{i t}\right)+\omega_{i t}+\eta_{i t}
\end{array}
$$

Hence, we re-estimated our preferred model specification (Column (6) of Table 5.4) in one step. Table 5.6 shows that the estimated coefficients and standard errors of the intangible assets are roughly the same for both approaches. The estimated coefficients of the intangible assets are slightly smaller in the two-stage TFP approach, while the capital coefficient is slightly larger. This points to a correlation of intangible and physical capital. In contrast to the two step results, the one-step approach indicates constant returns to scale. 
Table 5.6: Robustness Check: Labour Productivity vs. TFP

\begin{tabular}{|c|c|c|c|c|c|c|}
\hline \multirow[b]{3}{*}{ Capital } & \multicolumn{4}{|c|}{ Two-Stage Approach } & \multirow{2}{*}{\multicolumn{2}{|c|}{$\begin{array}{c}\text { Single-Stage Approach } \\
\text { (3) } \\
\text { Lab. Prod. }\end{array}$}} \\
\hline & \multicolumn{2}{|c|}{$\begin{array}{c}(1) \\
\text { 1st stage }\end{array}$} & \multicolumn{2}{|c|}{$\begin{array}{c}(2) \\
\text { 2nd stage (TFP) }\end{array}$} & & \\
\hline & $0.131^{* * *}$ & $(0.038)$ & & & $0.116^{* * *}$ & $(0.036)$ \\
\hline Labour & $-0.012^{* * *}$ & $(0.004)$ & & & -0.002 & $(0.004)$ \\
\hline Material & $0.378^{* * *}$ & $(0.007)$ & & & $0.357^{* * *}$ & $(0.007)$ \\
\hline \multicolumn{7}{|l|}{ Innovative Capital } \\
\hline R\&D & & & $0.031^{* * *}$ & $(0.005)$ & $0.033^{* * *}$ & $(0.005)$ \\
\hline Design \& Licenses & & & $0.005^{*}$ & $(0.003)$ & $0.005^{*}$ & $(0.003)$ \\
\hline Patent Stock & & & 0.005 & $(0.005)$ & 0.004 & $(0.005)$ \\
\hline \multicolumn{7}{|l|}{ Human Capital } \\
\hline Training & & & $0.039 * * *$ & $(0.005)$ & $0.044^{* * *}$ & $(0.005)$ \\
\hline High Skilled Labour & & & $0.266^{* * *}$ & $(0.026)$ & $0.263^{* * *}$ & $(0.028)$ \\
\hline \multicolumn{7}{|l|}{ Branding Capital } \\
\hline Marketing & & & $0.030^{* * *}$ & $(0.003)$ & $0.034^{* * *}$ & $(0.003)$ \\
\hline Trademark Stock & & & $0.022^{* * *}$ & $(0.005)$ & $0.025^{* * *}$ & $(0.006)$ \\
\hline \multicolumn{7}{|l|}{ Controls } \\
\hline East Germany & $-0.156^{* * *}$ & $(0.010)$ & -0.006 & $(0.010)$ & $-0.160^{* * *}$ & $(0.010)$ \\
\hline Group & $0.147^{* * *}$ & $(0.013)$ & $-0.034^{* * *}$ & $(0.011)$ & $0.122^{* * *}$ & $(0.012)$ \\
\hline Export & $0.160 * * *$ & $(0.024)$ & $-0.084^{* * *}$ & $(0.020)$ & $0.084^{* * *}$ & $(0.024)$ \\
\hline W_Time & 0.022 & & 0.000 & & 0.000 & \\
\hline W_Industry & 0.000 & & 0.000 & & 0.000 & \\
\hline Adjusted R̂ि & 0.702 & & 0.066 & & 0.724 & \\
\hline Observations & 11,021 & & 11,021 & & 11,021 & \\
\hline
\end{tabular}

Notes: Significance levels: $* * * \mathrm{p}<0.01, * * \mathrm{p}<0.05, * \mathrm{p}<0.1$. Standard errors in parentheses. Estimation method: Olley and Pakes (1996). The number of observations refers to the first stage regression. In the nonlinear regression of the second stage remain due to the time structure 5,453 observations. Regression additionally includes six dummies indicating R\&D, Design \& Licenses, Patent Stock, Firm-specific Training, Marketing, and Trademark Stock is zero.

\section{Revenue vs. Value Added}

Instead of using labour productivity, measured as sales per employee, the production function could also be specified in terms of value added:

$$
v a_{i t}-l_{i t}=\beta_{0}+\beta_{k}\left(k_{i t}-l_{i t}\right)+\omega_{i t}+\eta_{i t}
$$

where $v a_{i t}$ denotes value added, defined as sales less material costs (in logs). The sample is slightly reduced since value added is negative for 102 observations and the corresponding logarithm is not defined. The exclusion of this special group of observations could potentially affect the estimates, but the results in Table 5.7 show only minor deviation of the results from those of the full sample (Table 5.4). Qualitatively the value added approach yields the same results, i.e. except for patents all intangible asset components are highly significant. But the coefficients change in magnitude. The capital coefficient is almost twice as large in the value added specification and the all intangible asset components are considerably larger 
than in the revenue specification.

Table 5.7: Robustness Check: Value Added

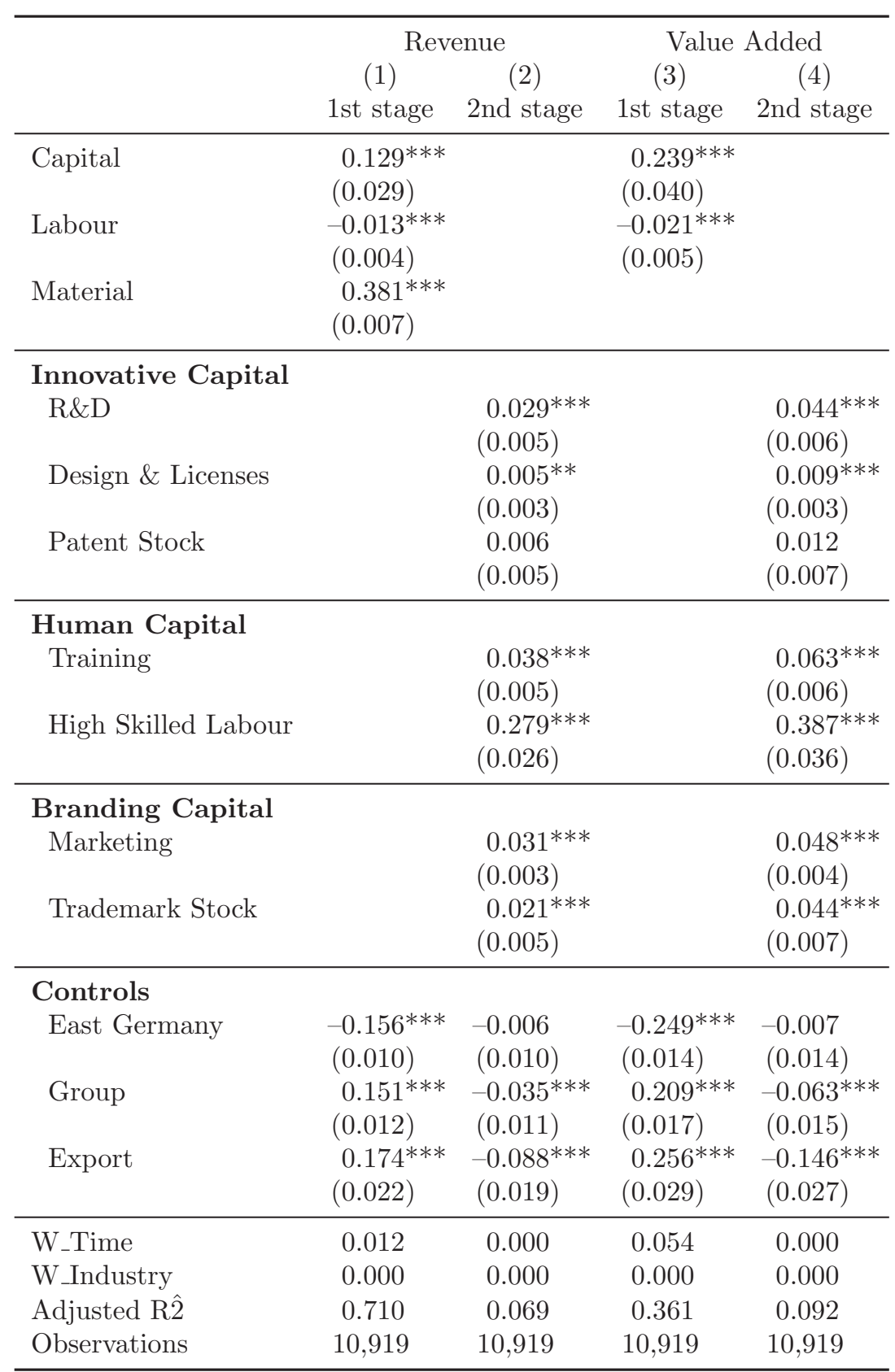

Notes: Significance levels: ${ }^{* * *} \mathrm{p}<0.01,{ }^{*} * \mathrm{p}<0.05,{ }^{*} \mathrm{p}<0.1$. Standard errors in parentheses. Estimation method: Olley and Pakes (1996). The number of observations refers to the first stage regression. In the nonlinear regression of the second stage remain due to the time structure 5,354 observations. Regression additionally includes six dummies indicating R\&D, Design \& Licenses, Patent Stock, Firm-specific Training, Marketing, and Trademark Stock is zero.

\section{Proxy of Capital Stocks: Expenses versus PIM}

In section 5.6.2, we extended the production function to account for different types of knowledge-related intangible capital. Except for Patents, Trademarks and High 
Skilled Labour and in contrast to physical capital, however, we have used expenses as proxies for intangible capital stocks up to now. The main reasons are due to the fact that the observed time period is rather short in order to construct intangible capital stocks and that the panel is highly unbalanced.

We check whether this difference in measurement impacts our results by using a more balanced subsample. For firms in the subsample we employ the well-known Perpetual Inventory Method (PIM) to derive capital stocks from a flow of investments (Griliches 1979). The intangible capital stock IC of firm $i$ in year $t$ is defined as:

$$
I C_{i, t}=(1-\delta) I C_{i, t-1}+I_{i, t-1}^{R}+I_{i, t-1}^{N}
$$

where $\delta$ is the depreciation rate, and investment $\left(I_{i, t-1}\right)$ of firm $i$ in year $t-1$ is composed of a replacement $\left(I_{i, t-1}^{R}\right)$ and net investment $\left(I_{i, t-1}^{N}\right)$. The replacement investment corresponds to the depreciated capital $\left(\delta I C_{i, t-1}\right)$ and net investment represents the change in the capital stock $\left(\gamma I C_{i, t-1}\right)$. Hence, we can write total investment as:

$$
I_{i, t-1}=\delta I C_{i, t-1}+\gamma I C_{i, t-1}
$$

It could be argued that it takes some time for a firm to achieve the desired optimal level of an intangible capital stock and by assuming that this process follows a partial adjustment mechanism (Chirinko et al. 1999, Nadiri and Rosen 1969), the assumption of constant investment growth $(\gamma)$ might be plausible. Moreover, the closer the capital stock to the long term optimum, the smaller is the net investment and thus the assumption of a constant growth rate is less of a concern.

The assumption of constant growth and depreciation rates leads to the following formula

$$
I C_{i, t}=\frac{I_{i, t}}{\delta+\gamma}
$$

which is widely used to approximate capital stocks. Up to now, we have approximated the capital stock by intangible investment. Multiplying investment with a constant (such as $(\delta+\gamma)^{-1}$ ), as suggested in Equation (5.12) has no effect on the estimated elasticities in the logarithmic specification of the production function. Thus, our approach is robust against any choice of (constant) depreciation and growth rates.

In contrast to this approach, a longer and more balanced panel allows us to relax the assumption of a constant growth rate but not that of a constant depreciation rate and to use the PIM method to construct capital stocks. We approximate the initial capital stock by multiplying intangible investment with the constant $(\delta+\gamma)^{-1}$. We use intangible-specific depreciation rates $\delta$ following Corrado et al. (2009). Intangiblespecific growth rates $\gamma$ are based on the development of intangible expenditures in Germany for each component for the pre-sample period 1995 to 2006 (Crass et al., 2015, see Table 5.13 in the Appendix). The initial capital stocks are perpetuated 
using the very same depreciation rates and actual expenditures.

Table 5.8: Intangibles Proxied by Expenses versus PIM Capital Stocks

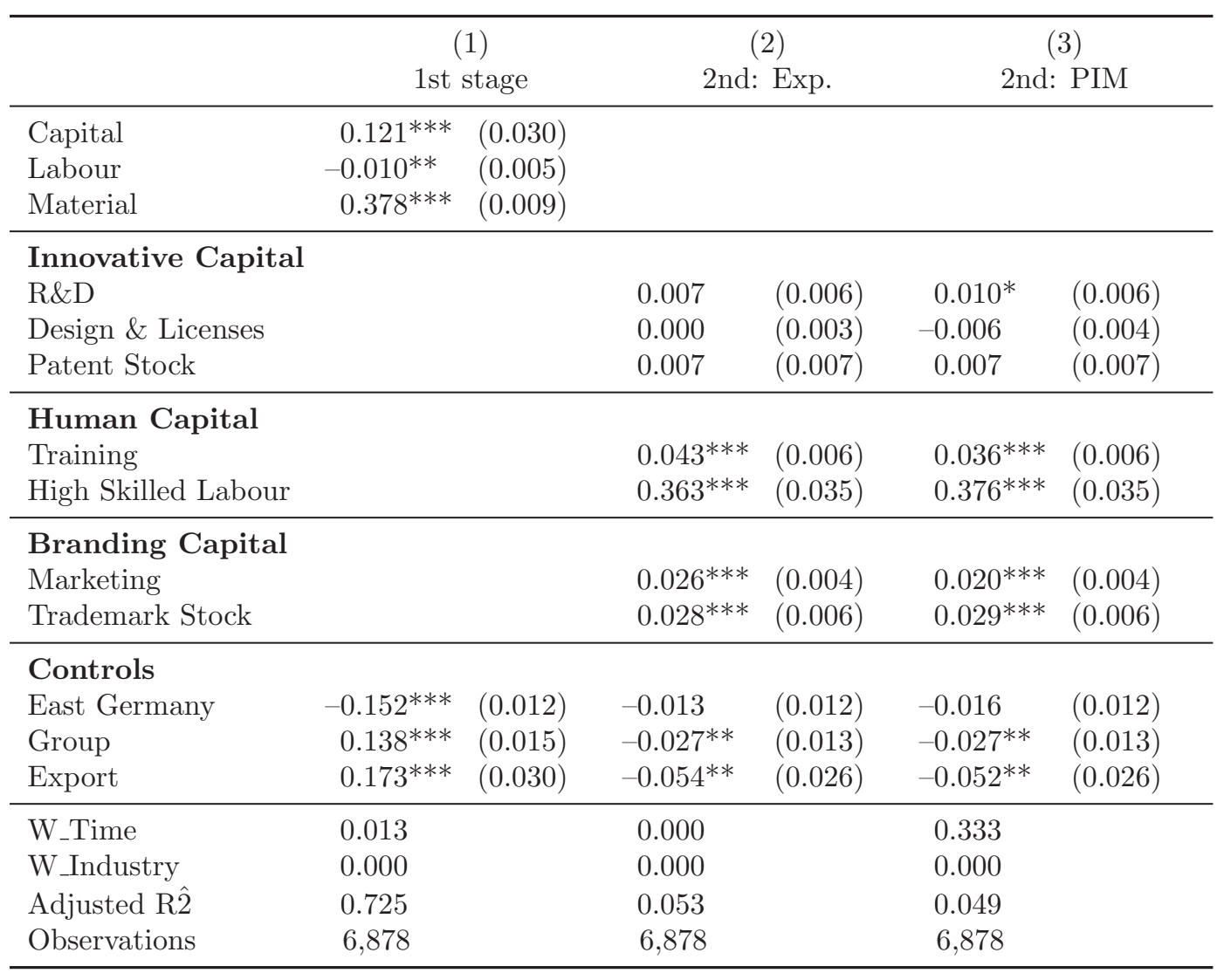

Notes: Significance levels: ${ }^{* * *} \mathrm{p}<0.01,{ }^{* *} \mathrm{p}<0.05,{ }^{*} \mathrm{p}<0.1$. Standard errors in parentheses. Estimation method: Olley and Pakes (1996). The number of observations refers to the first stage regression. Regression additionally includes six dummies indicating R\&D, Design \& Licenses, Training, Marketing, and Trademark Stock is zero.

Table 5.8 compares estimation results using PIM capital stocks (Column 1) with results for intangibles proxied by expenses (Column 2). PIM capital stocks are calculated for R\&D, Design \& Licenses, Training, and Marketing. Overall, results are very similar in both regressions. For the reduced subsample, we still find HC and $\mathrm{BC}$ to be productivity enhancing. In contrast R\&D and Design \& Licenses are not significant using expenditures but $R \& D$ becomes significant again in the PIM-version. Both are estimated by a subsample of 6,876 observations.

The results show that expenses qualify as proxies for capital stocks from our theoretical considerations as well as from the empirical results presented above.

\subsubsection{The Role of Organizational Investment on Productiv- ity}

Our estimates so far might have neglected an other important type of intangible assets: Organizational Capital. As explained in section 5.4 it is still a difficult task to measure organizational capital and we consider the introduction of an organizational 
innovation as an improvement in Organizational Capital. We extend equation 5.7 by including three dummy variables indicating organizational innovation in business practices, workplace organization and external relationships.

Table 5.9: Effect of Organizational Investment on Firm-Level Productivity

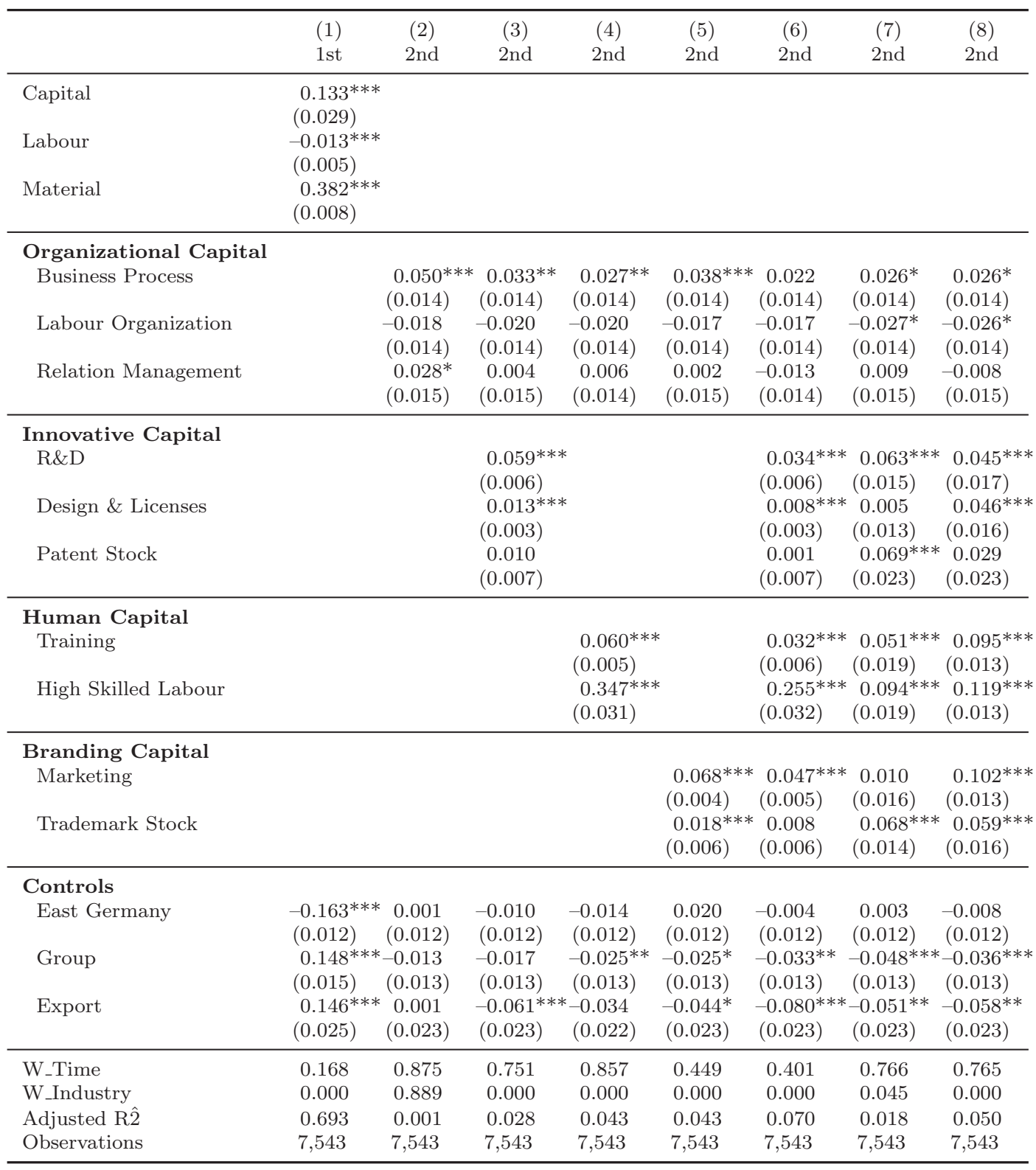

Notes: Significance levels: $* * * \mathrm{p}<0.01, * * \mathrm{p}<0.05, * \mathrm{p}<0.1$. Standard errors in parentheses. Estimation method: Olley and Pakes (1996). The number of observations refers to the first stage regression in OP. Due to the time structure 5,132 observations remain in the non-linear regression of the second stage. Regression additionally includes six dummies indicating R\&D, Design \& Licenses, Firm-specific Training, Marketing, and Trademark Stock is zero. In Column (7) and (8) Innovative, Human, and Branding Capital is measured by dummy variables: Column (7): Each component of IC, HC, BC is measured by a dummy variable which is 1 for positive expenditures. Column (8): Like Column (7) but dummy is 1 for expenditures larger than the median.

Table 5.9 illustrates the effects of organizational capital on productivity. In Columns (2) to (5), we explore the role of organizational capital on productivity when we stepwise include other types of intangible assets. Column (6) presents the full model specification. Overall, the results for Organizational Capital are mixed. Innovations in firms' business processes and external relations turn out to be significant in (2) 
when we do not account for other intangible assets. However, these productivity effects get smaller when we account for additional intangible assets and they even vanish in the full model specification (6). Whereas the productivity stimulus of traditional input factors and intangibles assets (with the exception of patents and trademarks) remains positive and significant, the different types of organizational innovations seems to have no significant impact on labour productivity.

One explanation why we find significant effects for R\&D, Human and Branding Capital but not for Organizational Capital might be rooted in the fact that the first ones are quantitative measures whereas Organizational Capital is a dummy variable. We therefore dig deeper and check robustness of our results by measuring innovative, human and branding capital using dummy variables that equal 1 if the corresponding expenditure or stock is positive and zero else (Column 7). These indicator variables incorporate less information thus it is maybe not surprising that we do not find any effect for Design \& Licenses and Marketing due to the limited information content of these variables. On the contrary, the effects of R\&D, Patents, Human Capital and Trademarks survive even using indicator variables. In contrast to Column (6), Organizational Capital matters in Column (7). We find improvements in business processes to foster productivity whereas changes in workplace organization lead on average to a decline in productivity (at least in the short-run). As an alternative Column (8) employs indicator variables for Innovative, Human and Branding Capital which take the value one if the firm invests a disproportionate high share in these intangibles above the median. The results are provided in column (8). Unlike in Column (7), the results confirm strong productivity enhancing effects for all proxies for Innovative, Human and Branding Capital and thus corroborate findings from our main regression in Table 5.4. But we still yield the same mixed results for Organizational Capital.

\subsubsection{Complementarity Between Intangible Assets}

Finally, we are interested in the question whether complementary or substitutive relations between various components of Innovative Capital, Human Capital, and Branding Capital exist. Complementarity (substitutability) between two intangibles is defined as an increase (decrease) in total factor productivity of one intangible asset through the investment in another intangible.

Since we have multiple components of intangible assets which are quantitative in nature, we follow a recent methodology by Carree et al. (2011) to test whether complementarity or substitutability exist. They emphasize that with more than two practices, estimates of only pair-wise interaction effects are potentially biased, since the joint investment in several intangibles might affect marginal productivity as well. Their approach considers, in consequence, the impact of all additional cross-terms. Starting point of their test procedure is the objective function 
$f\left(x_{1}, x_{2}, x_{3}, x_{4}, x_{5}, x_{6}, x_{7}\right)$ which includes all combinations of cross-terms of intangible components $x_{1}$ to $x_{7}$. The test indicates complementarity of two components $\left(x_{1}\right.$ and $\left.x_{2}\right)$ if the cross derivative of the objective function is non-negative $\left(\partial^{2} f / \partial x_{1} \partial x_{2} \geq 0\right)$ for all values $\left(x_{1}, x_{2}, x_{3}, x_{4}, x_{5}, x_{6}, x_{7}\right)$ with the inequality being strictly positive for at least one value. The definition for substitutability applies accordingly; the cross derivatives have to be non-positive with at least one strictly negative.

The cross-derivatives constitute the hypotheses, that are tested simultaneously. In our case of seven components of intangible capital, the number of hypotheses is 32 . The objective function is rewritten according to the hypotheses (see Table 5.A.4 in the appendix) and all separate hypotheses are tested simultaneously using linear regression. The combined hypothesis of complementarity or substitutability is accepted if all the separate hypotheses are accepted. Carree et al. (2011) show that in this setting the test indicates complementarity between two components, if the coefficient for at least one of the 32 variables representing the hypotheses is positive and significant while none of the coefficients of the other variables (hypotheses) is significantly negative and vice versa for substitutability. Since we have multiple restrictions, the significance level of the combined hypotheses is adjusted by the Bonferroni and alternatively by the Sidak procedure.

The seven components of intangible assets allow for 21 pair-wise combinations that are tested for complementarity or substitutability relations. Table 5.10 provides results only for those three combinations that turn out to be significant. The results show some interesting relationships between different kind of intangible assets. We find two components of Innovative Capital, R\&D and Patent Stock, to be complements. R\&D is proxied by current expenses and indicates a firm's innovation input, while the Patent Stock captures the firm's whole patenting history and the (patentable) output of its innovation activities. The complementarity of these two components indicate that marginal productivity of $R \& D$ increases if the Patent Stock increases. This points to the importance of a stock of prior knowledge as basis for a learning effect. Prior knowledge leads also to the creation of "absorptive capacity" (Cohen and Levin, 1989), which makes investments in a firm's research and development activities more productive.

The results furthermore show innovative capital and human capital on the one hand and innovative capital and branding capital on the other hand to be complements with respect to productivity. To be more precise, the patent stock and skilled labour are complementary, suggesting that a firm's human capital is a key asset to make commercial use of the patented technological knowledge more productive. We also find patents and marketing to be complements, that is the marginal return of the technological knowledge, captured by the patent stock, increases, as the marketing intensity increases. This finding stresses the importance of a firm's ability to successfully market innovative products, in addition to its ability to develop the technological basis for these products in the first place. Marketing enhance the commercial 
Table 5.10: Complementarities and Substitutabilities

\begin{tabular}{|c|c|c|c|}
\hline & (1) & $(2)$ & (3) \\
\hline Test & $\mathrm{R} \& \mathrm{D} \times$ Patents & Patents $\times$ Skilled Labour & Patents $\times$ Marketing \\
\hline H1 & . & . & . \\
\hline $\mathrm{H} 2$ & . & . & . \\
\hline H3 & . & . & \\
\hline $\mathrm{H} 4$ & $(+++)$ & . & $(++)$ \\
\hline H5 & . & . & \\
\hline H6 & . & . & . \\
\hline $\mathrm{H} 7$ & . & . & \\
\hline $\mathrm{H} 8$ & $(+++)$ & & $(+)$ \\
\hline H9 & . & $(+)$ & \\
\hline H10 & & & \\
\hline H11 & $(++)$ & . & $(++)$ \\
\hline H12 & . & . & . \\
\hline H13 & . & . & \\
\hline H14 & . & . & $(++)$ \\
\hline H15 & $(+++)$ & . & $(++)$ \\
\hline H16 & & 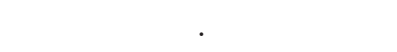 & \\
\hline H17 & $(++)$ & . & $(++)$ \\
\hline H18 & . & . & . \\
\hline H19 & . & & \\
\hline $\mathrm{H} 20$ & - & $(+)$ & \\
\hline $\mathrm{H} 21$ & $(+++)$ & . & \\
\hline H22 & . & . & \\
\hline $\mathrm{H} 23$ & . & . & $(++)$ \\
\hline $\mathrm{H} 24$ & $(++)$ & . & $(++)$ \\
\hline $\mathrm{H} 25$ & . & . & \\
\hline H26 & & . & $(+)$ \\
\hline $\mathrm{H} 27$ & & . & $(+)$ \\
\hline H28 & $(++)$ & . & $(+)$ \\
\hline $\mathrm{H} 29$ & . & . & . \\
\hline H30 & . & . & . \\
\hline H31 & 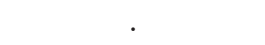 & . & $(++)$ \\
\hline H32 & & & \\
\hline
\end{tabular}

Notes: Estimation method: Olley and Pakes (1996). Bonferroni-corrected significance levels of complements: $(+++) \mathrm{p}<0.01,(++) \mathrm{p}<0.05,(+)$ $\mathrm{p}<0.1$. Significance levels of substitutes: $(---) \mathrm{p}<0.01,(--) \mathrm{p}<0.05$, $(-) \mathrm{p}<0.1$. Both corrections (Bonferroni and Sidak) lead to nearly identical results. A more detailed presentation of the hypotheses is provided in the Appendix section 5.A.4. Detailed regression results are available on request.

success because it helps to increase the awareness of potential customers. Marketing activities also influence the perception of desirable overall quality, and address favorable associations (Keller and Lehmann, 2006). Reciprocally, the patent stock might add to a firm's reputation and thus enhance the marginal return of marketing.

\subsection{Conclusion}

In contrast to many recent papers investigating the contribution of intangible assets to productivity growth at the macro level, this paper takes a firm-level perspective. 
It contributes to the literature by simultaneously investigating productivity effects of a comprehensive set of intangible assets following to a large extent the conceptual framework of Corrado et al. (2009). To the best of our knowledge, this paper is furthermore the first to investigate for a large set of intangibles whether they are complements or substitutes. In particular, our econometric approach accounts for Innovative Capital (measured by current R\&D expenditure, design \& licenses expenditure, and patent stock), Human Capital (proxied by training expenditure and share of high skilled labour), Branding Capital (measured by marketing expenditure and trademark stocks), and Organizational Capital (proxied by the introduction of different kinds of organizational innovations).

Table 5.11: Complementarity and Substitutability Between Intangibles

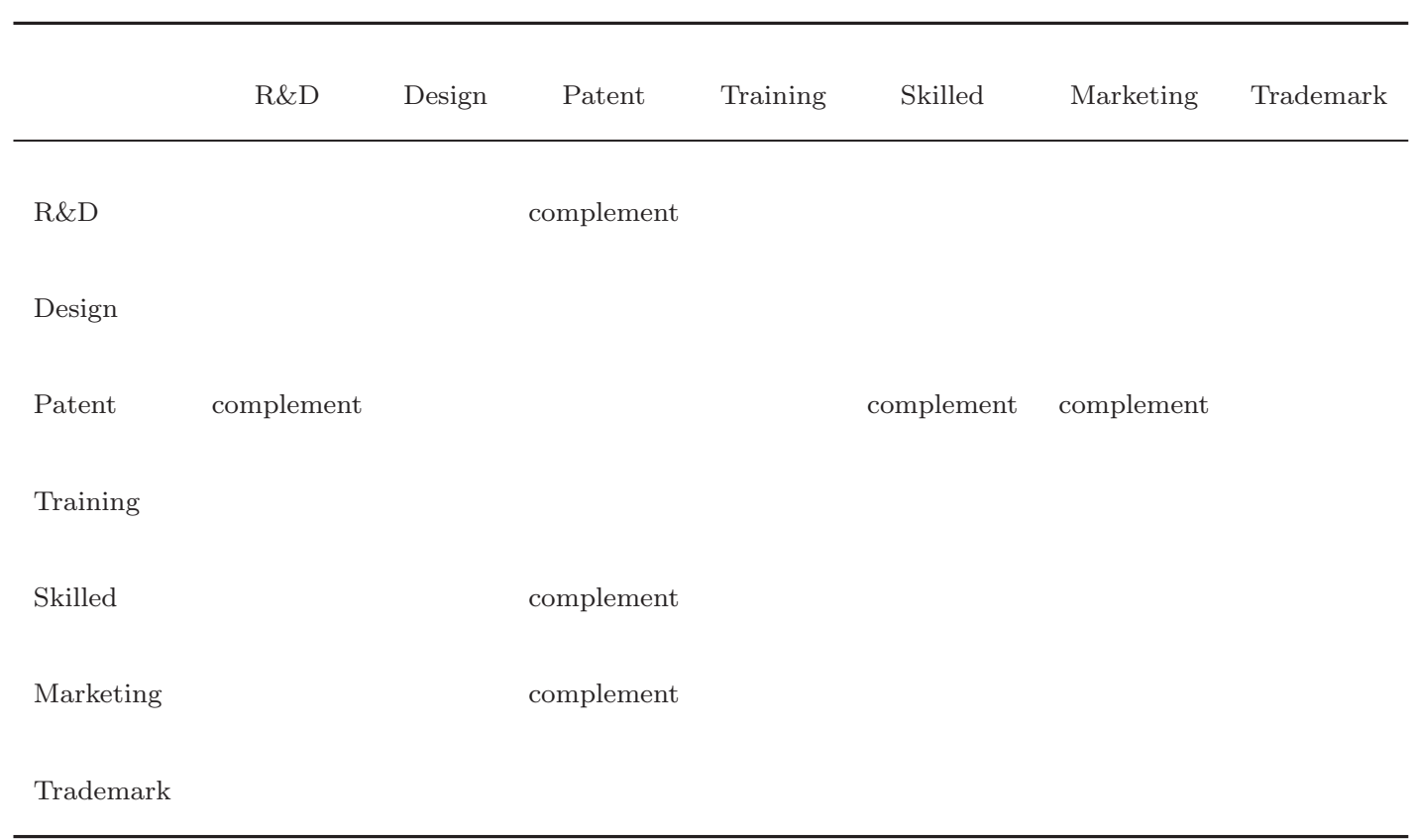

Using panel data for German companies covering the period 2006-2010, we can draw the following conclusions. First, even when controlling for a comprehensive set of intangible assets, we find strong productivity-enhancing effects for $R \& D$, Brand Capital and Human Capital. However, due to collinearity the single effects turn out to be smaller compared to studies that use one type of intangible assets only. Interestingly, the short-run productivity effect of an increase in training expenditure is stronger than for R\&D expenditure or marketing expenditure which are of similar size. Second, we also find slightly positive long-term productivity effects for firms investing in innovative capital and branding capital. That is both a firm's accumulated stock of granted patents and trademarks are conducive to current productivity. Third, our findings suggest that not only R\&D is productivity-enhancing. Firms that increase their expenditure for design and licenses also experienced productivity gains though the effect is rather small in magnitude. Fourth, results for Organizational Capital turn out to be mixed. We find a productivity enhancing 
effect for firms investing in organizational capital by changing business processes. However, the opposite holds when firms introduce new workplace organizations.

Fifth, our studies also show some interesting complementarities between different kinds of intangible assets. We find $\mathrm{R} \& \mathrm{D}$ and patent stocks to be complementary, pointing to the importance of prior knowledge and the creation of absorptive capacity. Furthermore, the results show innovative capital and human capital on the one hand and innovative capital and branding capital on the other hand to be complements with respect to productivity. We find in particular that the patent stock and skilled labour are complements as well as the patent stock and marketing. And finally, our results are robust to different parametric and non-parametric production function estimates accounting for selectivity and endogeneity, as well as different kinds of measurement of productivity and intangible capital. 


\section{A Appendix}

\section{A.1 Definition of Variables}

Table 5.12: Description and Definition of Main Variables

\begin{tabular}{|c|c|c|}
\hline Variable & Model & Description \\
\hline Labour Productivity & $\mathrm{Q} / \mathrm{L}$ & Turnover per employee in year $t$, in logs. \\
\hline Total Factor Productivity & TFP & TFP is computed based on equation 5.6. \\
\hline Value Added & VA & $\begin{array}{l}\text { Difference between turnover and expenses for materials per } \\
\text { employee in year t, in logs. }\end{array}$ \\
\hline Capital & $\mathbf{K}$ & $\begin{array}{l}\text { Physical capital stock (in book values) per employee in year } \\
\mathrm{t} \text {, in logs. Capital is updated by investments and a industry } \\
\text { specific depreciation rate. Book value and investments are } \\
\text { based on direct survey information. }\end{array}$ \\
\hline Labour & $\mathbf{L}$ & $\begin{array}{l}\text { Log number of employees in year } \mathrm{t} \text { (annual averages; incl. } \\
\text { apprentices and interns; without R\&D employees). }\end{array}$ \\
\hline Material & $\mathbf{M}$ & $\begin{array}{l}\text { Expenses for materials, intermediate inputs, and energy (incl. } \\
\text { ordered services) per employee in year } t \text {, in logs. }\end{array}$ \\
\hline Innovative Capital & IC & \\
\hline $\mathrm{R} \& \mathrm{D}$ & RD & $\begin{array}{l}R \& D \text { expenditures per employee in year } t \text {, in logs. } R \& D \text { in- } \\
\text { cludes in-house } R \& D \text { and external } R \& D(R \& D \text { contracted out } \\
\text { to third parties). }\end{array}$ \\
\hline Design \& Licenses & DL & $\begin{array}{l}\text { Expenses for design, licenses and other external knowledge } \\
\text { and product preparation related to innovation per employee } \\
\text { in year t; in logs. }\end{array}$ \\
\hline Patent Stock & $\mathbf{P}$ & $\begin{array}{l}\text { Stock of granted patents at the European Patent Office in year } \\
\mathrm{t}-1 \text {, in logs. A depreciation rate of } 15 \% \text { is applied. }\end{array}$ \\
\hline Human Capital & $\mathrm{HC}$ & \\
\hline Training & $\mathbf{T}$ & $\begin{array}{l}\text { Expenditures for professional development training (internal } \\
\text { and external per employee in year } t \text {, in logs. }\end{array}$ \\
\hline High Skilled Labour & SL & Share of employees holding a university or college degree. \\
\hline Branding Capital & $\mathrm{BC}$ & \\
\hline Marketing & $\mathbf{M}$ & $\begin{array}{l}\text { Marketing expenditures per employee in year t, in logs. In- } \\
\text { cludes all internal and external expenditures for advertise- } \\
\text { ment, for the conceptual design of marketing strategies, mar- } \\
\text { ket and costumer research, and the installation of new distri- } \\
\text { bution channels, without market expenditures for innovation } \\
\text { projects. }\end{array}$ \\
\hline Trademark Stock & TM & $\begin{array}{l}\text { Stock of registered trademarks at the German Patent and } \\
\text { Trademark Office (DPMA) and the Office for Harmonisation } \\
\text { in the Internal Market (OHIM) without depreciation per em- } \\
\text { ployee in year t-1, in logs. }\end{array}$ \\
\hline Organisational Capital & $\mathrm{OC}$ & \\
\hline Business Processes & BP & $\begin{array}{l}\text { Organizational investment in business processes (e.g. intro- } \\
\text { duction of quality management systems, supply chain manage- } \\
\text { ment systems, lean production, matrix organization, knowl- } \\
\text { edge management) in the period } t-2 \text { to } t \text {. }\end{array}$ \\
\hline Labour Organization & LO & $\begin{array}{l}\text { Organizational investment in labour organization (e.g. decen- } \\
\text { tralization or centralization of decision making, job rotation, } \\
\text { team work, basic realignment of departments) in the period } \\
t-2 \text { to } t \text {. }\end{array}$ \\
\hline Relation Management & RM & $\begin{array}{l}\text { Organizational investment in external relations (e.g. alliances, } \\
\text { cooperation agreements, outsourcing, customer relationship, } \\
\text { supplier integration) in the period } t-2 \text { to } t \text {. }\end{array}$ \\
\hline \multicolumn{3}{|l|}{ Control Variables } \\
\hline Industry & I & Set of 25 industry dummies. \\
\hline Export intensity & EX & Share of exports in turnover in year $\mathrm{t}(0 / 1)$. \\
\hline East Germany & $\mathbf{E}$ & Headquarter in East Germany in year $\mathrm{t}(0 / 1)$. \\
\hline Group & G & Company is part of a group in year t $(0 / 1)$. \\
\hline
\end{tabular}




\section{A.2 Depreciation and Growth Rates}

Table 5.13: Depreciation- and Growth Rates for Intangibles

\begin{tabular}{lcc}
\hline & $\begin{array}{c}\text { Growth rate } \\
\text { (in \%) }\end{array}$ & $\begin{array}{c}\text { Depreciation } \\
\text { rate (in \%) }\end{array}$ \\
\hline R\&D & 2.48 & 20.00 \\
Design \& Licenses & 2.48 & 20.00 \\
Marketing & -0.55 & 60.00 \\
Training & 0.03 & 40.00 \\
\hline
\end{tabular}

Notes: Growth rates are based on time series of intangibles for Germany for the time period 1995-2006 (Crass et al., 2015). Depreciation rates have been taken from Corrado et al. (2009).

\section{A.3 Correlation Matrix}

Table 5.14: Correlation Coefficients of Intangibles (Dummy-Variables)

\begin{tabular}{|c|c|c|c|c|c|c|c|c|c|c|}
\hline & $\mathrm{RD}$ & DL & $\mathrm{P}$ & $\mathrm{T}$ & $\mathrm{SL}$ & $\mathrm{M}$ & TM & $\mathrm{BP}$ & LO & $\mathrm{RM}$ \\
\hline $\mathrm{RD}$ & \multicolumn{10}{|c|}{1.00} \\
\hline DL & \multicolumn{10}{|c|}{$0.37^{* * * *} 1.00$} \\
\hline $\mathrm{P}$ & \multicolumn{10}{|c|}{$0.36^{* * *} 0.17^{* * *} 1.00$} \\
\hline $\mathrm{T}$ & \multicolumn{10}{|c|}{$0.19^{* * *} 0.16^{* * *} 0.11^{* * *} 1.00$} \\
\hline SL & \multicolumn{10}{|c|}{$0.22^{* * *} 0.14^{* * *} 0.13^{* * *} 0.26^{* * *} 1.00$} \\
\hline M & \multicolumn{10}{|c|}{$0.21^{* * *} 0.17^{* * *} 0.10^{* * *} 0.25^{* * *} 0.13^{* * *} 1.00$} \\
\hline TM & \multicolumn{10}{|c|}{$0.33^{* * *} 0.20^{* * *} 0.39^{* * *} 0.16^{* * *} 0.20^{* * *} 0.21^{* * *} 1.00$} \\
\hline $\mathrm{BP}$ & \multicolumn{10}{|c|}{$0.28^{* * *} 0.24^{* * *} 0.14^{* * *} 0.19^{* * *} 0.14^{* * *} 0.13^{* * *} 0.14^{* * *} 1.00$} \\
\hline $\mathrm{LO}$ & \multicolumn{10}{|c|}{$0.21^{* * *} 0.19^{* * *} 0.09^{* * *} 0.15^{* * *} 0.11^{* * *} 0.13^{* * *} 0.10^{* * *} 0.47^{* * *} 1.00$} \\
\hline $\mathrm{RM}$ & \multicolumn{10}{|c|}{$0.24^{* * *} 0.19^{* * *} 0.10^{* * *} 0.13^{* * *} 0.11^{* * *} 0.15^{* * *} 0.13^{* * *} 0.34^{* * *} 0.36^{* * *} 1.00$} \\
\hline
\end{tabular}

Notes: Significance levels: $* * * \mathrm{p}<0.01,{ }^{*} * \mathrm{p}<0.05,{ }^{*} \mathrm{p}<0.1$. 


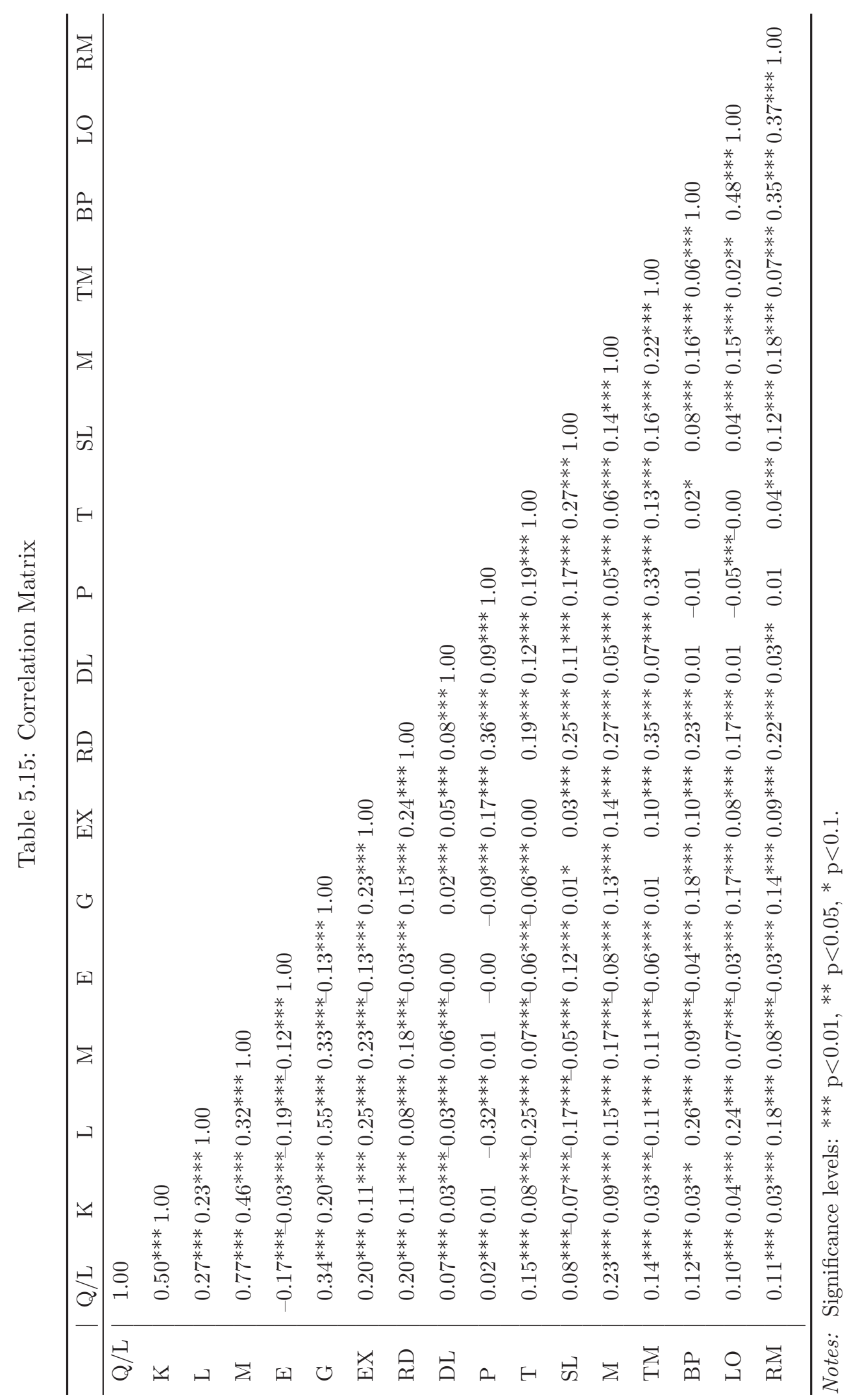




\section{A.4 Testing for Complementarity}

\section{Overview of variables and hypotheses for seven practices}

\begin{tabular}{|c|c|c|}
\hline \# & Variable & Hypothesis \\
\hline$(1)$ & $\begin{array}{l}x_{1} x_{2}\left(1-x_{3}\right)\left(1-x_{4}\right)\left(1-x_{5}\right)(1- \\
\left.x_{6}\right)\left(1-x_{7}\right)\end{array}$ & $\alpha_{12} \geqslant 0$ \\
\hline$(2)$ & $x_{1} x_{2} x_{3}\left(1-x_{4}\right)\left(1-x_{5}\right)\left(1-x_{6}\right)\left(1-x_{7}\right)$ & $\alpha_{12}+\alpha_{123} \geqslant 0$ \\
\hline$(3)$ & $x_{1} x_{2}\left(1-x_{3}\right) x_{4}\left(1-x_{5}\right)\left(1-x_{6}\right)\left(1-x_{7}\right)$ & $\alpha_{12}+\alpha_{124} \geqslant 0$ \\
\hline$(4)$ & $x_{1} x_{2}\left(1-x_{3}\right)\left(1-x_{4}\right) x_{5}\left(1-x_{6}\right)\left(1-x_{7}\right)$ & $\alpha_{12}+\alpha_{125} \geqslant 0$ \\
\hline$(5)$ & $x_{1} x_{2}\left(1-x_{3}\right)\left(1-x_{4}\right)\left(1-x_{5}\right) x_{6}\left(1-x_{7}\right)$ & $\alpha_{12}+\alpha_{126} \geqslant 0$ \\
\hline$(6)$ & $x_{1} x_{2}\left(1-x_{3}\right)\left(1-x_{4}\right)\left(1-x_{5}\right)\left(1-x_{6}\right) x_{7}$ & $\alpha_{12}+\alpha_{127} \geqslant 0$ \\
\hline$(7)$ & $x_{1} x_{2} x_{3} x_{4}\left(1-x_{5}\right)\left(1-x_{6}\right)\left(1-x_{7}\right)$ & $\alpha_{12}+\alpha_{123}+\alpha_{124}+\alpha_{1234} \geqslant 0$ \\
\hline$(8)$ & $x_{1} x_{2} x_{3}\left(1-x_{4}\right) x_{5}\left(1-x_{6}\right)\left(1-x_{7}\right)$ & $\alpha_{12}+\alpha_{123}+\alpha_{125}+\alpha_{1235} \geqslant 0$ \\
\hline$(9)$ & $x_{1} x_{2} x_{3}\left(1-x_{4}\right)\left(1-x_{5}\right) x_{6}\left(1-x_{7}\right)$ & $\alpha_{12}+\alpha_{123}+\alpha_{126}+\alpha_{1236} \geqslant 0$ \\
\hline$(10)$ & $x_{1} x_{2} x_{3}\left(1-x_{4}\right)\left(1-x_{5}\right)\left(1-x_{6}\right) x_{7}$ & $\alpha_{12}+\alpha_{123}+\alpha_{127}+\alpha_{1237} \geqslant 0$ \\
\hline$(11)$ & $x_{1} x_{2}\left(1-x_{3}\right) x_{4} x_{5}\left(1-x_{6}\right)\left(1-x_{7}\right)$ & $\alpha_{12}+\alpha_{124}+\alpha_{125}+\alpha_{1245} \geqslant 0$ \\
\hline$(12)$ & $x_{1} x_{2}\left(1-x_{3}\right) x_{4}\left(1-x_{5}\right) x_{6}\left(1-x_{7}\right)$ & $\alpha_{12}+\alpha_{124}+\alpha_{126}+\alpha_{1246} \geqslant 0$ \\
\hline$(13)$ & $x_{1} x_{2}\left(1-x_{3}\right) x_{4}\left(1-x_{5}\right)\left(1-x_{6}\right) x_{7}$ & $\alpha_{12}+\alpha_{124}+\alpha_{127}+\alpha_{1247} \geqslant 0$ \\
\hline$(14)$ & $x_{1} x_{2}\left(1-x_{3}\right)\left(1-x_{4}\right) x_{5} x_{6}\left(1-x_{7}\right)$ & $\alpha_{12}+\alpha_{125}+\alpha_{126}+\alpha_{1256} \geqslant 0$ \\
\hline$(15)$ & $x_{1} x_{2}\left(1-x_{3}\right)\left(1-x_{4}\right) x_{5}\left(1-x_{6}\right) x_{7}$ & $\alpha_{12}+\alpha_{125}+\alpha_{127}+\alpha_{1257} \geqslant 0$ \\
\hline$(16)$ & $x_{1} x_{2}\left(1-x_{3}\right)\left(1-x_{4}\right)\left(1-x_{5}\right) x_{6} x_{7}$ & $\alpha_{12}+\alpha_{126}+\alpha_{127}+\alpha_{1267} \geqslant 0$ \\
\hline$(17)$ & $x_{1} x_{2} x_{3} x_{4} x_{5}\left(1-x_{6}\right)\left(1-x_{7}\right)$ & $\alpha_{12}+\alpha_{123}+\alpha_{124}+\alpha_{125}+\alpha_{1234}+\alpha_{1235}+\alpha_{1245}+\alpha_{12345} \geqslant 0$ \\
\hline$(18)$ & $x_{1} x_{2} x_{3} x_{4}\left(1-x_{5}\right) x_{6}\left(1-x_{7}\right)$ & $\alpha_{12}+\alpha_{123}+\alpha_{124}+\alpha_{126}+\alpha_{1234}+\alpha_{1236}+\alpha_{1246}+\alpha_{12346} \geqslant 0$ \\
\hline$(19)$ & $x_{1} x_{2} x_{3} x_{4}\left(1-x_{5}\right)\left(1-x_{6}\right) x_{7}$ & $\alpha_{12}+\alpha_{123}+\alpha_{124}+\alpha_{127}+\alpha_{1234}+\alpha_{1237}+\alpha_{1247}+\alpha_{12347} \geqslant 0$ \\
\hline$(20)$ & $x_{1} x_{2} x_{3}\left(1-x_{4}\right) x_{5} x_{6}\left(1-x_{7}\right)$ & $\alpha_{12}+\alpha_{123}+\alpha_{125}+\alpha_{126}+\alpha_{1235}+\alpha_{1236}+\alpha_{1256}+\alpha_{12356} \geqslant 0$ \\
\hline$(21)$ & $x_{1} x_{2} x_{3}\left(1-x_{4}\right) x_{5}\left(1-x_{6}\right) x_{7}$ & $\alpha_{12}+\alpha_{123}+\alpha_{125}+\alpha_{127}+\alpha_{1235}+\alpha_{1237}+\alpha_{1257}+\alpha_{12357} \geqslant 0$ \\
\hline$(22)$ & $x_{1} x_{2} x_{3}\left(1-x_{4}\right)\left(1-x_{5}\right) x_{6} x_{7}$ & $\alpha_{12}+\alpha_{123}+\alpha_{126}+\alpha_{127}+\alpha_{1236}+\alpha_{1237}+\alpha_{1267}+\alpha_{12367} \geqslant 0$ \\
\hline$(23)$ & $x_{1} x_{2}\left(1-x_{3}\right) x_{4} x_{5} x_{6}\left(1-x_{7}\right)$ & $\alpha_{12}+\alpha_{124}+\alpha_{125}+\alpha_{126}+\alpha_{1245}+\alpha_{1246}+\alpha_{1256}+\alpha_{12456} \geqslant 0$ \\
\hline$(24)$ & $x_{1} x_{2}\left(1-x_{3}\right) x_{4} x_{5}\left(1-x_{6}\right) x_{7}$ & $\alpha_{12}+\alpha_{124}+\alpha_{125}+\alpha_{127}+\alpha_{1245}+\alpha_{1247}+\alpha_{1257}+\alpha_{12457} \geqslant 0$ \\
\hline$(25)$ & $x_{1} x_{2}\left(1-x_{3}\right) x_{4}\left(1-x_{5}\right) x_{6} x_{7}$ & $\alpha_{12}+\alpha_{124}+\alpha_{126}+\alpha_{127}+\alpha_{1246}+\alpha_{1247}+\alpha_{1267}+\alpha_{12467} \geqslant 0$ \\
\hline$(26)$ & $x_{1} x_{2}\left(1-x_{3}\right)\left(1-x_{4}\right) x_{5} x_{6} x_{7}$ & $\alpha_{12}+\alpha_{125}+\alpha_{126}+\alpha_{127}+\alpha_{1256}+\alpha_{1257}+\alpha_{1267}+\alpha_{12567} \geqslant 0$ \\
\hline$(27)$ & $x_{1} x_{2} x_{3} x_{4} x_{5} x_{6}\left(1-x_{7}\right)$ & $\begin{array}{l}\alpha_{12}+\alpha_{123}+\alpha_{124}+\alpha_{125}+\alpha_{126}+\alpha_{1234}+\alpha_{1235}+\alpha_{1236}+ \\
\alpha_{1245}+\alpha_{1246}+\alpha_{1256}+\alpha_{12345}+\alpha_{12346}+\alpha_{12356}+\alpha_{12456}+ \\
\alpha_{123456} \geqslant 0\end{array}$ \\
\hline$(28)$ & $x_{1} x_{2} x_{3} x_{4} x_{5}\left(1-x_{6}\right) x_{7}$ & $\begin{array}{l}\alpha_{12}+\alpha_{123}+\alpha_{124}+\alpha_{125}+\alpha_{127}+\alpha_{1234}+\alpha_{1235}+\alpha_{1237}+ \\
\alpha_{1245}+\alpha_{1247}+\alpha_{1257}+\alpha_{12345}+\alpha_{12347}+\alpha_{12357}+\alpha_{12457}+ \\
\alpha_{123457} \geqslant 0\end{array}$ \\
\hline$(29)$ & $x_{1} x_{2} x_{3} x_{4}\left(1-x_{5}\right) x_{6} x_{7}$ & $\begin{array}{l}\alpha_{12}+\alpha_{123}+\alpha_{124}+\alpha_{126}+\alpha_{127}+\alpha_{1234}+\alpha_{1236}+\alpha_{1237}+ \\
\alpha_{1246}+\alpha_{1247}+\alpha_{1267}+\alpha_{12346}+\alpha_{12347}+\alpha_{12367}+\alpha_{12467}+ \\
\alpha_{123467} \geqslant 0\end{array}$ \\
\hline$(30)$ & $x_{1} x_{2} x_{3}\left(1-x_{4}\right) x_{5} x_{6} x_{7}$ & $\begin{array}{l}\alpha_{12}+\alpha_{123}+\alpha_{125}+\alpha_{126}+\alpha_{127}+\alpha_{1235}+\alpha_{1236}+\alpha_{1237}+ \\
\alpha_{1256}+\alpha_{1257}+\alpha_{1267}+\alpha_{12356}+\alpha_{12357}+\alpha_{12367}+\alpha_{12567}+ \\
\alpha_{123567} \geqslant 0\end{array}$ \\
\hline$(31)$ & $x_{1} x_{2}\left(1-x_{3}\right) x_{4} x_{5} x_{6} x_{7}$ & $\begin{array}{l}\alpha_{12}+\alpha_{124}+\alpha_{125}+\alpha_{126}+\alpha_{127}+\alpha_{1245}+\alpha_{1246}+\alpha_{1247}+ \\
\alpha_{1256}+\alpha_{1257}+\alpha_{1267}+\alpha_{12456}+\alpha_{12457}+\alpha_{12467}+\alpha_{12567}+ \\
\alpha_{124567} \geqslant 0\end{array}$ \\
\hline$(32)$ & $x_{1} x_{2} x_{3} x_{4} x_{5} x_{6} x_{7}$ & $\begin{array}{l}\alpha_{12}+\alpha_{123}+\alpha_{124}+\alpha_{125}+\alpha_{126}+\alpha_{127}+\alpha_{1234}+\alpha_{1235}+ \\
\alpha_{1236}+\alpha_{1237}+\alpha_{1245}+\alpha_{1246}+\alpha_{1247}+\alpha_{1256}+\alpha_{1257}+ \\
\alpha_{1267}+\alpha_{12345}+\alpha_{12346}+\alpha_{12347}+\alpha_{12356}+\alpha_{12357}+\alpha_{12367}+ \\
\alpha_{12456}+\alpha_{12457}+\alpha_{12467}+\alpha_{12567}+\alpha_{123456}+\alpha_{123457}+ \\
\alpha_{123467}+\alpha_{123567}+\alpha_{124567}+\alpha_{1234567} \geqslant 0\end{array}$ \\
\hline
\end{tabular}

Based on Carree et al. (2011). 


\section{A.5 Industry Differences}

Column (1) and (2) provide evidence for the subsample of firms in manufacturing and services, respectively. The following columns (3) to (5) further split manufacturing firms into low-tech (including energy and construction), medium-tech, and high-tech industry according to the OECD/Eurostat classification. Column (6) and column (7) distinguish between firms belonging to knowledge-intensive and low-knowledgeintensive service industries.

Table 5.16: Effect of Intangibles on Firm-Level Productivity: 1st Stage

\begin{tabular}{lccccccc}
\hline & $(1)$ & $(2)$ & $(3)$ & $(4)$ & $(5)$ & $(6)$ & $(7)$ \\
& Manuf. & Serv. & LT-M & MT-M & HT-M & KI-S & LKI-S \\
\hline Capital & $0.087^{* *}$ & $0.157^{* * *}$ & $0.074^{*}$ & 0.044 & $0.117^{* *}$ & $0.189^{* * *}$ & $0.121^{* *}$ \\
& $(0.035)$ & $(0.041)$ & $(0.040)$ & $(0.043)$ & $(0.052)$ & $(0.054)$ & $(0.060)$ \\
Labour & $-0.011^{* * *}$ & $-0.026^{* * *}$ & 0.002 & $-0.018^{* * *}$ & $-0.019^{*}$ & -0.010 & $-0.046^{* * *}$ \\
& $(0.004)$ & $(0.007)$ & $(0.007)$ & $(0.004)$ & $(0.010)$ & $(0.008)$ & $(0.011)$ \\
Material & $0.476^{* * *}$ & $0.306^{* * *}$ & $0.493^{* * *}$ & $0.459^{* * *}$ & $0.453^{* * *}$ & $0.292^{* * *}$ & $0.307^{* * *}$ \\
& $(0.011)$ & $(0.009)$ & $(0.018)$ & $(0.016)$ & $(0.025)$ & $(0.010)$ & $(0.021)$ \\
East Germany & $-0.117^{* * *}$ & $-0.204^{* * *}$ & $-0.097^{* * *}$ & $-0.146^{* * *}$ & $-0.154^{* * *}$ & $-0.188^{* * *}$ & $-0.232^{* * *}$ \\
& $(0.011)$ & $(0.019)$ & $(0.019)$ & $(0.014)$ & $(0.031)$ & $(0.022)$ & $(0.035)$ \\
Group & $0.118^{* * *}$ & $0.165^{* * *}$ & $0.162^{* * *}$ & $0.108^{* * *}$ & $0.067^{*}$ & $0.148^{* * *}$ & $0.172^{* * *}$ \\
& $(0.014)$ & $(0.024)$ & $(0.027)$ & $(0.015)$ & $(0.035)$ & $(0.030)$ & $(0.038)$ \\
Export & $0.150^{* * *}$ & $0.098^{* *}$ & $0.203^{* * *}$ & $0.125^{* * *}$ & $0.194^{* * *}$ & 0.083 & 0.117 \\
& $(0.021)$ & $(0.047)$ & $(0.046)$ & $(0.025)$ & $(0.054)$ & $(0.058)$ & $(0.090)$ \\
\hline W_Time & 0.063 & 0.443 & 0.308 & 0.010 & 0.001 & 0.090 & 0.382 \\
W_Industry & 0.000 & 0.000 & 0.178 & 0.000 & 0.000 & 0.000 & 0.000 \\
Adjusted $R^{2}$ & 0.755 & 0.667 & 0.771 & 0.783 & 0.680 & 0.696 & 0.553 \\
Observations & 6,622 & 4,400 & 2,481 & 3,198 & 943 & 2,941 & 1,459 \\
\hline
\end{tabular}

Notes: Significance levels: $* * * \mathrm{p}<0.01,{ }^{*} \mathrm{p}<0.05, * \mathrm{p}<0.1$. Standard errors in parentheses. Estimation method: Olley and Pakes (1996). LTM, MTM, and HTM denote low-tech manufacturing (including energy and construction), medium-tech manufacturing, and high-tech manufacturing. KIS denotes knowledge-intensive and LKIS low-knowledge-intensive services. 
Table 5.17: Effect of Intangibles on Firm-Level Productivity: 2nd Stage

\begin{tabular}{|c|c|c|c|c|c|c|c|}
\hline & $\begin{array}{c}\text { (1) } \\
\text { Manuf. }\end{array}$ & $\begin{array}{c}(2) \\
\text { Serv. }\end{array}$ & $\begin{array}{c}(3) \\
\text { LT-M }\end{array}$ & $\begin{array}{c}(4) \\
\text { MT-M }\end{array}$ & $\begin{array}{c}(5) \\
\text { HT-M }\end{array}$ & $\begin{array}{c}(6) \\
\text { KI-S }\end{array}$ & $\begin{array}{c}(7) \\
\text { LKI-S }\end{array}$ \\
\hline \multicolumn{8}{|l|}{ Innovative Capital } \\
\hline \multirow{2}{*}{$\mathrm{R} \& \mathrm{D}$} & $0.026^{* * *}$ & * $0.034^{* * *}$ & * $0.037^{* * *}$ & $* 0.036^{* * *}$ & $* 0.028^{* *}$ & $0.033^{* * *}$ & $* 0.048$ \\
\hline & $(0.005)$ & $(0.009)$ & $(0.012)$ & $(0.007)$ & $(0.013)$ & $(0.010)$ & $(0.036)$ \\
\hline \multirow{2}{*}{ Design \& Licenses } & 0.000 & $0.019^{* *}$ & 0.002 & -0.001 & -0.002 & $0.028^{* * *}$ & $*-0.021$ \\
\hline & $(0.003)$ & $(0.009)$ & $(0.005)$ & $(0.004)$ & $(0.016)$ & $(0.010)$ & $(0.024)$ \\
\hline \multirow[t]{2}{*}{ Patent Stock } & 0.001 & $0.041^{* * *}$ & ${ }^{*}-0.029^{*}$ & 0.007 & $0.031^{* *}$ & $0.040^{* * *}$ & * $0.107^{* * *}$ \\
\hline & $(0.006)$ & $(0.012)$ & $(0.016)$ & $(0.006)$ & $(0.015)$ & $(0.013)$ & $(0.029)$ \\
\hline \multicolumn{8}{|l|}{ Human Capital } \\
\hline \multirow{2}{*}{ Firm-specific Training } & $0.031^{* * *}$ & * $0.048^{* * *}$ & * $0.042^{* * *}$ & * $0.026^{* * *}$ & $* 0.034^{* *}$ & $0.040^{* * *}$ & $* 0.062^{* * *}$ \\
\hline & $\begin{array}{l}(0.005) \\
0.295^{* * *}\end{array}$ & $\begin{array}{l}(0.009) \\
0.252^{* * *}\end{array}$ & $\begin{array}{l}(0.010) \\
0.309 * * *\end{array}$ & $\begin{array}{l}(0.007) \\
0.180 * * *\end{array}$ & $* \begin{array}{l}(0.014) \\
0.250^{* * * *}\end{array}$ & $\begin{array}{l}(0.011) \\
0.271^{* * *}\end{array}$ & $* \begin{array}{l}(0.018) \\
0.333^{* * *}\end{array}$ \\
\hline High Skilled Labour & $(0.040)$ & $(0.039)$ & $(0.068)$ & $(0.064)$ & $(0.074)$ & $(0.041)$ & $(0.121)$ \\
\hline \multicolumn{8}{|l|}{ Branding Capital } \\
\hline \multirow[t]{2}{*}{ Marketing } & $0.027^{*}$ & * $0.035^{* * *}$ & * $0.041^{* * *}$ & * $0.008^{* *}$ & $0.040^{* * *}$ & $0.031^{* *}$ & $0.043^{* *}$ \\
\hline & $(0.003)$ & $(0.006)$ & $(0.007)$ & $(0.004)$ & $(0.010)$ & $(0.008)$ & $(0.011)$ \\
\hline \multirow[t]{2}{*}{ Trademark Stock } & $0.017^{* * *}$ & $k^{*} 0.023^{* *}$ & $0.038^{* * *}$ & $*-0.001$ & 0.001 & 0.014 & $0.049^{*}$ \\
\hline & $(0.005)$ & $(0.011)$ & $(0.011)$ & $(0.006)$ & $(0.013)$ & $(0.012)$ & $(0.028)$ \\
\hline \multirow[t]{2}{*}{ East Germany } & -0.012 & 0.002 & -0.011 & -0.006 & -0.023 & -0.002 & 0.014 \\
\hline & $(0.011)$ & $(0.018)$ & $(0.019)$ & $(0.014)$ & $(0.030)$ & $(0.022)$ & $(0.032)$ \\
\hline \multirow[t]{2}{*}{ Group } & $-0.023^{* *}$ & -0.027 & $-0.039^{*}$ & 0.003 & -0.042 & -0.011 & -0.043 \\
\hline & $(0.011)$ & $(0.021)$ & $(0.021)$ & $(0.013)$ & $(0.029)$ & $(0.026)$ & $(0.034)$ \\
\hline \multirow[t]{2}{*}{ Export } & $-0.079^{* * *}$ & ${ }^{*}-0.065$ & -0.057 & -0.029 & $-0.200^{* * *}$ & *-0.092 & -0.002 \\
\hline & $(0.021)$ & $(0.046)$ & $(0.042)$ & $(0.027)$ & $(0.053)$ & $(0.057)$ & $(0.084)$ \\
\hline W_Time & 0.000 & 0.000 & 0.000 & 0.308 & 0.007 & 0.010 & 0.042 \\
\hline W_Industry & 0.000 & 0.000 & 0.008 & 0.000 & 0.144 & 0.000 & 0.254 \\
\hline Adjusted $R^{2}$ & 0.082 & 0.069 & 0.102 & 0.066 & 0.131 & 0.074 & 0.058 \\
\hline Observations & 6,622 & 4,400 & 2,481 & 3,198 & 943 & 2,941 & 1,459 \\
\hline
\end{tabular}

Notes: Significance levels: $* * * \mathrm{p}<0.01,{ }^{*} \mathrm{p}<0.05,{ }^{*} \mathrm{p}<0.1$. Standard errors in parentheses. Estimation method: Olley and Pakes (1996). The number of observations refers to the first stage regression. Regression additionally includes six dummies indicating R\&D, Design \& Licenses, Firm-specific Training, Marketing, and Trademark Stock is zero. LTM, MTM, and HTM denote low-tech manufacturing (including energy and construction), medium-tech manufacturing, and high-tech manufacturing. KIS denotes knowledge-intensive and LKIS lowknowledge-intensive services. 


\section{Chapter 6}

\section{Concluding Discussion}

\subsection{Overall Summary}

The thesis explores the use and the impact of brands on firm performance. It investigates the use of trademark registrations by firms, the effect of brands on innovation performance and the impact of brand-related investments on overall firm profitability. In the last productivity chapter it compares the effect of brands with the effect of other types of intangibles and examines whether complementarity exists between different kinds of intangible assets. Employing a representative sample of German firms, the German part of the Community Innovation Survey (CIS), the data set of the studies contain also many small and medium-sized firms. Most of these firms are not required to publish any data. This constitutes an important difference to other studies. Other studies relying on publicly available firm level information, most likely use a selective sample of large firms which are not representative for the economy. The studies of this dissertation are able to avoid this limitation.

For this thesis trademark application data have been prepared and merged to firmlevel data. The administrative trademark data provides detailed information on a firm's trademark applications filed with, or registrations issued by, the German Patent and Trademark Office (DPMA) and the Office for Harmonization in the Internal Market (OHIM). Firm-level data is obtained from the Mannheim Innovation Panel (MIP), which is the German version of the Community Innovation Survey (CIS). Surveyed firms have been linked with information on firm's trademark activity by matching the name of the firms participating in the innovation survey with the names of applicants at the OHIM and the DPMA using a special software developed at ZEW, and including an extensive manual double-check.

Chapter 2 provides empirical evidence of the proportion of firms that have registered trademarks in 2010 and analyses the role of several firm characteristics that are related to a firm's decision to register trademarks. The empirical analysis relies on a large sample of about 5,400 German firms from many different industries in the German business sector. The extrapolated proportion of $18 \%$ of firms with at least 
one registered and still valid trademark is representative for all firms with more than five employees in corresponding sectors. In the empirical analysis, I examine which factors explain the propensity of firms to have at least one registered trademark that is still valid in 2010. The results cannot be taken as indicating causality because of potential endogeneity. But the empirical results point to circumstances under which trademarks are significantly more often used: this is the case when a large distance between a firm and its customers exists, a firm's product quality is difficult to assess, a firm's products are characterized by a limited (but not strong) substitutability, and when a firm is engaged in $R \& D$ and introduces innovative products. Trademarks are considerably less frequently used if none of the factors are present.

A firm has to decide whether it uses brand names to introduce its product innovations into the market place. Branded product innovations have the potential to achieve a higher level of awareness among the target audience, might profit from the reputation of the brand, and allow a firm to better appropriate the returns from its innovations (Aaker, 2007). Chapter 3 makes use of German 2011 Community Innovation Survey (CIS), which provides a direct link between the introduction of a firm's product innovations and its use of a new or an established brand. The descriptive analysis shows that about $38 \%$ of product innovating firms introduce new products under a brand. About $26.5 \%$ of the firms rely on already established brands, while about $14 \%$ introduce product innovations under a new brand name. The focus of this chapter is on the question whether branded product innovations achieve a higher economic performance. The results suggest that branded product innovations are more successful in terms of sales with these products. The empirical results could be driven by the unobservable quality of the firm's innovation, so that this can not be interpreted as causal effects. The use of an established brand is, however, associated to remarkable $35 \%$ higher sales with product innovations.

Brand equity contributes to the financial performance of a firm in two ways: It affects revenues positively and decreases marketing costs. The successful development of brand equity requires, however, the investment of substantial marketing efforts and it is a priori unclear whether these investments pay off for an average firm. Chapter 4 investigates the relationship between past brand-related investments and current financial performance for a representative sample of German firms. We use a standard model of profitability and proxy brand-related investments by the flow of trademark registrations over a long period of thirty years. The flow of investments is not consolidated in a stock formulation but is used to estimate the contribution of brand-related investments within a distributed lag model. This is a major difference to most other studies which use a stock formulation. Our results support the view that continual investment is needed to maintain brand equity. Brand-related investments have a long-run impact on a firm's profit margin, but show no significant short-term impact. We find that the contribution of brand equity to profits is not only statistically significant but also economically. The median firm that conducts 
brand-related investments achieves a contribution of EUR 273.000 per year to its profits.

Chapter 5 contributes to the literature by simultaneously investigating productivity effects of a comprehensive set of intangible assets following the conceptual framework of Corrado et al. (2009) and by asking whether different kinds of intangible assets are complements or substitutes. In particular, our econometric approach accounts for Innovative Capital (measured by current R\&D expenditure, design \& licenses expenditure, and patent stock), Human Capital (proxied by training expenditure and share of high skilled labour), Branding Capital (measured by marketing expenditure and trademark stocks), and Organizational Capital (proxied by the introduction of an organizational innovation). Using panel data for German companies covering the period 2006-2010, we can draw the following conclusions. First, even when controlling for a comprehensive set of intangible assets, we find strong positive productivity effects for R\&D, brand capital and firm-specific human capital. However, due to collinearity the single effects turn out to be smaller compared to studies that use one type of intangible assets only. Second, we also find positive long-term productivity effects for firms investing in innovative capital and branding capital. That is both a firm's accumulated stock of granted patents and trademarks are conducive to current productivity. Our studies also show some interesting relationships between different kind of intangible assets. We find R\&D and patent stocks to be complementary, pointing to the importance of prior knowledge and the creation of absorptive capacity. Furthermore, the results show innovative capital and human capital on the one hand and innovative capital and branding capital on the other hand to be complements with respect to productivity.

\subsection{Limitations and Future Research}

The research presented in this thesis has some limitations. The limitations of the empirical studies are mostly data-driven. Measuring intangible assets and their impacts is a challenging task due to data limitations. The improved concepts applied in chapter 5 still have shortcomings. A major part of the intangible asset components are measured by current expenses instead of stocks. Since most intangible assets are not capitalised in a firm's balance sheets and the only way to calculate intangible capital stocks is the use of expenses. Longer time series are needed to improve those stocks. We use a comprehensive set of intangible assets, including innovation capital, branding capital, and human capital. The comprehensive set used is still incomplete. Intangible assets like organisational capital or software and databases are crude measures or not available at all. Organisational capital is measured by dummy variables which indicate some investment in organisational capital. The information content of the dummy variables is limited, but more detailed data is not available. However, firms' expenses for software have been recently included in the 2013 survey. 
Future research can also investigate the impact of a more complete set of intangible assets, including software, on firm productivity. The use of cross-sectional data has its own limitations. The timing of the variables does not allow us to interpret the results as causal effects. The studies in chapter 2 and chapter 3 rely on crosssectional data. These studies make use of the flexibility of the German CIS and rely on additional questions, included in the survey 2011. These additional questions make the study possible but the results have to be interpreted as associations rather than causal relationships. The study in chapter 4 uses a firm's history of trademark registrations as proxy for its brand-related investments. While major investments in a firm's brand equity are likely to be accompanied by trademark registrations, investments that are not trademarked are neglected. A more complete panel of a firm's marketing activities would be needed to avoid this limitation. 


\section{Chapter 7}

\section{Bibliography}

Aaker, D. A. (1991), Managing brand equity: capitalizing on the value of a brand name, New York: The Free Press.

Aaker, D. A. (2007), 'Innovation: Brand It or Lose It', California Management Review 50(1), 8-24.

Abramovsky, L. and Griffith, R. (2009), ICT, Corporate Restructuring and Productivity, Institute for Fiscal Studies Working Papers W09/10.

Ailawadi, K. L., Neslin, S. A. and Lehmann, D. R. (2003), 'Revenue Premium as an Outcome Measure of Brand Equity', Journal of Marketing 67(4), 1-17.

Akerlof, G. A. (1970), 'The Market for 'Lemons': Quality Uncertainty and the Market Mechanism', The Quarterly Journal of Economics 84(3), 488-500.

Amara, N., Landry, R. and Traor, N. (2008), 'Managing the protection of innovations in knowledge-intensive business services', Research Policy 37(9), 1530-1547.

Aschhoff, B., Baier, E., Crass, D., Hud, M., Hünermund, P., Köhler, C., Peters, B., Rammer, C., Schricke, E., Schubert, T. et al. (2013), Innovation in Germany - Results of the German CIS 2006 to 2010. Background report on the Innovation Surveys 2007, 2009 and 2011 of the Mannheim Innovation Panel, Zew-dokumentation 13-01, Mannheim.

Bagwell, K. (2007), The Economic Analysis of Advertising, Handbook of Industrial Organization, Vol. 3, Elsevier, chapter 28, pp. 1701-1844.

Bahadir, S. C., Bharadwaj, S. G. and Srivastava, R. K. (2008), 'Financial Value of Brands in Mergers and Acquisitions: Is Value in the Eye of the Beholder?', Journal of Marketing 72(6), 49-64.

Ballot, G., Fakhfakh, F. and Taymaz, E. (2006), 'Who Benefits from Training and R\&D, the Firm or the Workers?', British Journal of Industrial Relations 44(3), 473-495. 
Barney, J. (1991), 'Firm Resources and Sustained Competitive Advantage', Journal of Management 17(1), 99-120.

Baroncelli, E., Fink, C. and Javorcik, B. K. S. (2004), The Global Distribution of Trademarks: Some Stylized Facts, World Bank Publications.

Belderbos, R., Carree, M., Diederen, B., Lokshin, B. and Veugelers, R. (2004), 'Heterogeneity in R\&D cooperation strategies', International Journal of Industrial Organization 22(8/9), 1237-1263.

Bertschek, I. (2003), 'Information technology and productivity gains and cost savings in companies', New Economy Handbook, Elsevier Science, Amsterdam pp. 213228.

Bertschek, I. and Kaiser, U. (2004), 'Productivity Effects of Organizational Change: Microeconometric Evidence', Management Science, INFORMS 50(3), 394-404.

Black, S. E. and Lynch, L. (1996), 'Human-Capital Investments and Productivity', American Economic Review 86(2), 263-267.

Black, S. E. and Lynch, L. M. (2001), 'How To Compete: The Impact Of Workplace Practices And Information Technology On Productivity', The Review of Economics and Statistics 83(3), 434-445.

Bloom, N., Sadun, R. and van Reenen, J. (2010), 'Recent Advances in the Empirics of Organizational Economics', Annual Review of Economics 2(1), 105-137.

Bloom, N., Sadun, R. and van Reenen, J. (2012), 'The Organization of Firms Across Countries', The Quarterly Journal of Economics 127(4), 1663-1705.

Bloom, N. and van Reenen, J. (2007), 'Measuring and Explaining Management Practices Across Firms and Countries', Quarterly Journal of Economics 122(4), 13411408 .

Bontempi, M. E. and Mairesse, J. (2014), 'Intangible Capital and Productivity at the Firm Level: A Panel Data Assessment', Economics of Innovation and New Technology (ahead-of-print), 1-30.

Borden, N. H. (1944), The Economic Effects of Advertising, 3rd edn, Richard D. Irwin, Chicago.

Bosworth, D. and Rogers, M. (2001), 'Market Value, R\&D and Intellectual Property: An Empirical Analysis of Large Australian Firms', The Economic Record $77(239), 323-337$. 
Bresnahan, T. F. (2002), Prospects for an Information-Technology-Led Productivity Surge, in 'Innovation Policy and the Economy, Volume 2', NBER Chapters, National Bureau of Economic Research, Inc, pp. 135-162.

Brynjolfsson, E. and Hitt, L. (1996), 'Paradox Lost? Firm-Level Evidence on the Returns to Information Systems Spending', Management Science 42(4), 541-558.

Brynjolfsson, E. and Hitt, L. M. (2003), 'Computing Productivity: Firm-Level Evidence', Review of Economics and Statistics 85(4), 793-808.

Buddelmeyer, H., Jensen, P. H. and Webster, E. (2010), 'Innovation and the determinants of company survival', Oxford Economic Papers 62(2), 261-285.

Buil, I., de Chernatony, L. and Martinez, E. (2013), 'Examining the role of advertising and sales promotions in brand equity creation', Journal of Business Research 66(1), 115-122.

Cameron, A. C. and Trivedi, P. K. (2009), Microeconometrics using STATA, Vol. 5, Stata Press College Station, TX.

Carree, M., Lokshin, B. and Belderbos, R. (2011), 'A note on testing for complementarity and substitutability in the case of multiple practices', Journal of Productivity Analysis 35(3), 263-269.

Cassiman, B. and Veugelers, R. (2006), 'In Search of Complementarity in Innovation Strategy: Internal R\&D and External Knowledge Acquisition', Management Science 52(1), 68-82.

Ceccagnoli, M., Graham, S. J., Higgins, M. J. and Lee, J. (2010), 'Productivity and the role of complementary assets in firms' demand for technology innovations', Industrial and Corporate Change 19(3), 839-869.

Chudnovsky, D., López, A. and Pupato, G. (2006), 'Innovation and productivity in developing countries: A study of Argentine manufacturing firms' behavior (19922001)', Research Policy 35(2), 266-288.

Cohen, W. M. and Levin, R. C. (1989), Empirical Studies of Innovation and Market Structure, in R. M. A. Schmalensee and R. D. Willig, eds, 'Handbook of Industrial Organization', Vol. 2, Elsevier, pp. 1059-1107.

Cohen, W. M. and Levinthal, D. A. (1990), 'Absorptive Capacity: A New Perspective on Learning and Innovation', Administrative Science Quarterly pp. 128-152.

Corrado, C. A. and Hao, J. X. (2014), Brands As Productive Assets: Concepts, Measurement, and Global Trends, WIPO Economic Research Working Papers 13. 
Corrado, C., Hulten, C. and Sichel, D. (2009), 'Intangible capital and economic growth', The Review of Income and Wealth 55(3), 661-685.

Crass, D., Czarnitzki, D. and Toole, A. A. (2014), The Profitability of Trademark Portfolios - Microeconometric Evidence for Germany, mimeo.

Crass, D., Licht, G. and Peters, B. (2015), Intangible Assets and Investments at the Sector Level - Empirical Evidence for Germany, in A. Bonfour and T. Miyagawa, eds, 'Intangibles, Market Failure and Innovation Performance', Springer.

Crass, D., Licht, G., Peters, B. and Sofka, W. (2009), Time Series Estimates of Intangible Investments - Sensitivity Analysis for Germany, Technical report, ZEW, Mannheim.

URL: www.coinvest.org.uk/bin/view/CoInvest/CoinvestPub

Crass, D. and Peters, B. (2014), Intangible Assets and Firm-Level Productivity, mimeo.

Crépon, B., Duguet, E. and Mairesse, J. (1998), 'Research, Innovation and Productivity: An Econometric Analysis at the Firm Level', Economics of Innovation and New Technology 7(2), 115-158.

Czarnitzki, D. and Kraft, K. (2010), 'On the profitability of innovative assets', Applied Economics 42(15), 1941-1953.

de la Fuente, A. (2011), Human capital and productivity, Barcelona Working paper 530, Barcelona.

Dearden, L., H., R. and van Reenen, J. (2006), 'The Impact of Training on Productivity and Wages: Evidence from British Panel Data', Oxford Bulletin of Economics \& Statistics 68, 397-421.

Doms, M. and Bartelsman, E. J. (2000), 'Understanding Productivity: Lessons from Longitudinal Microdata', Journal of Economic Literature 38(3), 569-594.

Doraszelski, U. and Jaumandreu, J. (2014), Measuring the Bias of Technological Change, mimeo.

Draca, M., Sadun, R. and van Reenen, J. (2007), 'ICT and Productivity: A Review of the Evidence', Handbook of Information and Communication Technologies .

Dubin, J. A. (2007), 'Valuing intangible assets with a nested logit market share model', Journal of Econometrics 139(2), 285-302.

Eberhardt, M. and Helmers, C. (2010), Untested Assumptions and Data Slicing: A Critical Review of Firm-Level Production Function Estimators, Economics Series Working Papers 513, University of Oxford, Department of Economics. 
Economides, N. (1998), 'Trademarks', The New Palgrave Dictionary of Economics and the Law (Peter Newman, Ed.) .

Eurostat (2013), Community Innovation Survey 2010: Synthesis Quality Report, Technical report, Eurostat, Luxembourg.

Farquhar, P. H. (1989), 'Managing Brand Equity', Marketing Research 1(3), 24 33.

Farquhar, P. H. (1990), 'Managing Brand Equity', Journal of Advertising Research $30(4), \mathrm{RC}-7-\mathrm{RC}-12$.

Fosfuri, A. and Giarratana, M. S. (2009), 'Masters of War: Rivals' Product Innovation and New Advertising in Mature Product Markets', Management Science $\mathbf{5 5}(2), 181191$.

Garcia, R. and Calantone, R. (2002), 'A critical look at technological innovation typology and innovativeness terminology: a literature review', Journal of Product Innovation Management 19(2), 110 - 132.

Graham, S., Hancock, G., Marco, A. and Myers, A. (2013), 'The USPTO Trademark Case Files Dataset: Descriptions, Lessons, and Insights'. Arlington.

Greenhalgh, C. and Longland, M. (2005), 'Running to Stand Still? - The Value of R\&D, Patents and Trade Marks in Innovating Manufacturing Firms', International Journal of the Economics of Business 12(3), 307-328.

Greenhalgh, C. and Rogers, M. (2012), 'Trade Marks and Performance in Services and Manufacturing Firms: Evidence of Schumpeterian Competition through Innovation', Australian Economic Review 45(1), 50-76.

Greenhalgh, C., Rogers, M., Schautschick, P. and Sena, V. (2011), Trade Mark Incentives, Report for the uk intellectual property office.

Griffith, R., Huergo, E., Mairesse, J. and Peters, B. (2006), 'Innovation and Productivity across Four European Countries', Oxford Review of Economic Policy 22(4), 483-498.

Griffiths, W., Jensen, P. H. and Webster, E. (2011), 'What Creates Abnormal Profits?', Scottish Journal of Political Economy 58(3), 323-346.

Griliches, Z. (1979), 'Issues in Assessing the Contribution of Research and Development to Productivity Growth', The Bell Journal of Economics 10(1), 92-116.

Griliches, Z. and Mairesse, J. (1984), Productivity and R\&D at the Firm Level, in 'R \& D, Patents, and Productivity', NBER Chapters, National Bureau of Economic Research, Inc, pp. 339-374. 
Grimes, A., Ren, C. and Stevens, P. (2012), 'The Need for Speed: Impacts of Internet Connectivity on Firm Productivity', Journal of Productivity Analysis 37(2), 187201.

Grimpe, C. and Kaiser, U. (2010), 'Balancing Internal and External Knowledge Acquisition: The Gains and Pains from R\&D Outsourcing', Journal of Management Studies 47(8), 1483 - 1509.

Gujarati, D. N. (2003), Basic Econometrics, 4th edn, McGraw-Hill Inc., US.

Hall, B. H. (1999), Innovation and Market Value, Working Paper 6984, National Bureau of Economic Research.

Hall, B. H., Helmers, C., Rogers, M. and Sena, V. (2012), The Choice between Formal and Informal Intellectual Property: A Literature Review, NBER Working Papers 17983. Cambridge, MA.

Hall, B. H., Lotti, F. and Mairesse, J. (2013), 'Evidence on the Impact of R\&D and ICT Investments on Innovation and Productivity in Italian Firms', Economics of Innovation and New Technology 22(3), 300-328.

Hall, B. H., Mairesse, J. and Mohnen, P. (2010), Measuring the Returns to R\&D, in B. H. Hall and N. Rosenberg, eds, 'Handbook of the Economics of Innovation', Vol. 2, Elsevier, chapter 22, pp. 1033-1082.

Hall, B. and Mairesse, J. (2006), 'Empirical studies of innovation in the knowledgedriven economy', Economics of Innovation and New Technology 15(4-5), 289-299.

Hao, J., Manole, V. and van Ark, B. (2009), Intangible Capital and Growth - an International Comparison, Coinvest deliverable d3.6: Paper quantifying figures on time-series estimates dating back to 1980, Brussels.

URL: www.coinvest.org.uk/bin/view/CoInvest/CoinvestPub

Hauser, J., Tellis, G. J. and Griffin, A. (2006), 'Research on Innovation: A Review and Agenda for Marketing Science', Marketing Science 25(6), 687-717.

Helmers, C. and Rogers, M. (2010), 'Innovation and the Survival of New Firms in the UK', Review of Industrial Organization 36(3), 227-248.

Hempell, T. (2005), 'Whats Spurious, Whats Real? Measuring the Productivity Impacts of ICT at the Firm-Level.', Empirical Economics 30(2), 427-464.

Jaffe, A. B. (1986), 'Technological Opportunity and Spillovers of R\&D: Evidence from Firms' Patents, Profits, and Market Values', American Economic Review 76(5), 984-1001. 
Jensen, P. H. and Webster, E. (2009), 'Another Look At The Relationship Between Innovation Proxies', Australian Economic Papers 48(3), 252-269.

Jensen, P. H., Webster, E. and Buddelmeyer, H. (2008), 'Innovation, Technological Conditions and New Firm Survival', The Economic Record 84(267), 434-448.

Keller, K. L. (2013), Strategic brand management: building, measuring, and managing brand equity, 4th edn, Pearson Education.

Keller, K. L. and Lehmann, D. R. (2006), 'Brands and Branding: Research Findings and Future Priorities', Marketing Science 25(6), 740-759.

Kirk, C. P., Ray, I. and Wilson, B. (2013), 'The impact of brand value on firm valuation: The moderating influence of firm type', Journal of Brand Management 20(6), $488-500$.

Klingebiel, R. and Rammer, C. (2014), 'Resource allocation strategy for innovation portfolio management', Strategic Management Journal 35(2), 246 - 268.

Konings, J. and Vanormelingen, S. (2009), The Impact of Training on Productivity and Wages: Firm Level Evidence, C.E.P.R. Discussion Papers 7473, London.

Krasnikov, A., Mishra, S. and Orozco, D. (2009), 'Evaluating the Financial Impact of Branding Using Trademarks: A Framework and Empirical Evidence', Journal of Marketing 73(6), $154-166$.

Kretschmer, T., Cardona, M. and Strobel, T. (2013), 'The Contribution of ICT to Productivity: Key Conclusions from Surveying the Empirical Literature', Information Economics and Policy 3(25), 109-125.

Landes, W. M. and Posner, R. A. (1987), 'Trademark Law: An Economic Perspective', Journal of Law and Economics 30(2), 265-309.

Laursen, K. and Salter, A. (2006), 'Open for innovation: the role of openness in explaining innovation performance among U.K. manufacturing firms', Strategic Management Journal 27(2), 131-150.

Leiponen, A. and Helfat, C. E. (2010), 'Innovation objectives, knowledge sources, and the benefits of breadth', Strategic Management Journal 31(2), 224-236.

Leone, R. P., Rao, V. R., Keller, K. L., Luo, A. M., McAlister, L. and Srivastava, R. (2006), 'Linking Brand Equity to Customer Equity', Journal of Service Research $\mathbf{9}(2), 125-138$.

Levinsohn, J. and Petrin, A. (2003), 'Estimating Production Functions Using Inputs to Control for Unobservables', Review of Economic Studies 70(2), 317-341. 
Licht, G. and Stahl, H. (1997), Ergebnisse der Innovationserhebung 1996, Technical report, ZEW-Dokumentation.

Löö, H. and Heshmati, A. (2002), 'Knowledge Capital and Performance Heterogeneity: A Firm-Level Innovation Study', International Journal of Production Economics, Elsevier 76(1), 61-85.

Mairesse, J. and Mohnen, P. (2002), 'Accounting for Innovation and Measuring Innovativeness: An Illustrative Framework and an Application', American Economic Review 92(2), 226-230.

Mairesse, J. and Mohnen, P. (2010), Using Innovations Surveys for Econometric Analysis, NBER Working Papers 15857, Cambridge, MA.

Mairesse, J. and Sassenou, M. (1991), R\&D Productivity: A Survey of Econometric Studies at the Firm Level, NBER Working Papers 3666, Cambridge, MA.

Marrano, G. and Haskel, J. (2007), How Much Does the UK Invest in Intangible Assets?, C.E.P.R Discussion Papers 6287, London.

Marrocu, E., Paci, R. and Pontis, M. (2012), 'Intangible capital and firms' productivity', Industrial and Corporate Change 21(2), 377-402.

Marschak, J. and Andrews, W. H. (1944), 'Random Simultaneous Equations and the Theory of Production', Econometrica 12(3), 143-205.

Mendonca, S., Pereira, T. S. and Godinho, M. M. (2004), 'Trademarks as an indicator of innovation and industrial change', Research Policy 33(9), 1385-1404.

Millot, V. (2011), Firms' intangible assets: who relies on trademarks? Analysis of French and German firms' trademarking behaviour, in 'paper presented at the DRUID Society Conference', Copenhagen, Denmark.

Moore, K. and Reid, S. (2008), 'The birth of brand: 4000 years of branding', Business History 50(4), 419-432.

OECD, Eurostat (2005), Oslo Manual: Guidelines for Collecting and Interpreting Innovation Data, 3rd edn, Paris.

Olley, G. S. and Pakes, A. (1996), 'The Dynamics of Productivity in the Telecommunications Equipment Industry', Econometrica 64(6), 1263-1297.

Pavitt, K. (1985), 'Patent statistics as indicators of innovative activities: Possibilities and problems', Scientometrics 7(1-2), 77-99.

Peters, B. (2008), Innovation and Firm Performance - An Empirical Investigation for German Firms, ZEW Economic Studies 38, Heidelberg, New York. 
Peters, B. (2009), 'Persistence of innovation: stylised facts and panel data evidence', The Journal of Technology Transfer 34(2), 226-243.

Peters, B. and Rammer, C. (2013), Innovation panel surveys in Germany, in F. Gault, ed., 'Handbook of Innovation Indicators and Measurement', Edward Elgar Publishing, Cheltenham, UK and Northampton, MA, USA, chapter 6, pp. $135-177$.

Peters, B. and Schmiele, A. (2010), The Influence of International Dispersed vs. Home-Based R\&D on Innovation Performance, ZEW Discussion Papers 10-102.

Peters, B. and Schmiele, A. (2011), The contribution of international R\&D to firm profitability, ZEW Discussion Papers 11-002, Mannheim.

Polder, M., van Leeuwen, G., Mohnen, P. and Raymond, W. (2009), Productivity effects of innovation modes, Discussion paper 09033, Statistics Netherlands, Den Haag.

Raggio, R. D. and Leone, R. P. (2007), 'The theoretical separation of brand equity and brand value: Managerial implications for strategic planning', Journal of Brand Management 14(5), 380 - 395.

Raggio, R. D. and Leone, R. P. (2009), 'Chasing brand value: Fully leveraging brand equity to maximise brand value', Journal of Brand Management 16(4), 248 - 263.

Ramello, G. B. (2006), 'What's in a Sign? Trademark Law And Economic Theory', Journal of Economic Surveys 20(4), 547-565.

Ramirez, P. and Hachiya, T. (2008), 'A comprehensive study on profits and sustainable competitive advantages', Management Research News 31(9), 670-682.

Rexhäuser, S. and Rammer, C. (2014), 'Environmental Innovations and Firm Profitability: Unmasking the Porter Hypothesis', Environmental \&6 Resource Economics 57(1), 145-167.

Rust, R. T., Ambler, T., Carpenter, G. S., Kumar, V. and Srivastava, R. K. (2004), 'Measuring Marketing Productivity: Current Knowledge and Future Directions', Journal of Marketing 68(4), 76 - 89.

Sáiz, P. and Fernández, P. (2009), Intangible Assets and Competitiveness in Spain: An Approach Based on Trademark Registration Data in Catalonia (1850-1946), Working Papers in Economic History 2009/01, Universidad Autnoma de Madrid (Spain), Department of Economic Analysis (Economic Theory and Economic History).

Sandner, P. G. and Block, J. (2011), 'The Market Value of R\&D, Patents, and Trademarks', Research Policy 40(7), 969-985. 
Sarbu, M. (2013), Does Social Software Increase Labour Productivity?, ZEW Discussion Papers 13-041.

Schautschick, P. and Greenhalgh, C. (2013), Empirical Studies of Trade Marks - The Existing Economic Literature, Discussion Paper Series 659, University of Oxford.

Schmalensee, R. (1982), 'Product Differentiation Advantages of Pioneering Brands', American Economic Review 72(3), 349-65.

Simon, C. J. and Sullivan, M. W. (1993), 'The Measurement and Determinants of Brand Equity: A Financial Approach', Marketing Science 12(1), 28-52.

Solow, R. M. (1987), 'We'd better watch out', New York Times Book Review p. 36.

Srinivasan, S., Hsu, L. and Fournier, S. (2011), 'Branding and firm value', Handbook of Marketing and Finance, Shankar Ganesan and Sunder Bharadwaj, eds., Edward Elgar Publishing .

Srinivasan, V., Park, C. S. and Chang, D. R. (2005), 'An Approach to the Measurement, Analysis, and Prediction of Brand Equity and Its Sources', Management Science 51(9), 1433-1448.

Stahl, F., Heitmann, M., Lehmann, D. R. and Neslin, S. A. (2012), 'The Impact of Brand Equity on Customer Acquisition, Retention, and Profit Margin', Journal of Marketing 76(4), $44-63$.

Syverson, C. (2011), 'What Determines Productivity?', Journal of Economic Literature 49(2), 326-65.

Vakratsas, D. and Ambler, T. (1999), 'How Advertising Works: What Do We Really Know?', Journal of Marketing 63(1), 26 - 43.

van Beers, C. and Zand, F. (2014), 'R\&D Cooperation, Partner Diversity, and Innovation Performance: An Empirical Analysis', Journal of Product Innovation Management 31(2), 292-312.

von Graevenitz, G. (2007), Which Reputations Does a Brand Owner Need? Evidence from Trade Mark Opposition, Discussion Paper Series of SFB/TR 15 Governance and the Efficiency of Economic Systems 215, Free University of Berlin, Humboldt University of Berlin, University of Bonn, University of Mannheim, University of Munich.

Wang, F., (Steven) Zhang, X.-P. and Ouyang, M. (2009), 'Does Advertising Create Sustained Firm Value? The Capitalization of Brand Intangible', Journal of the Academy of Marketing Science 37(2), 130 - 143. 
Williams, R. (2012), 'Using the Margins Command to Estimate and Interpret Adjusted Predictions and Marginal Effects', Stata Journal 12(2), 308-331.

WIPO (2013), World Intellectual Property Report: Brands - Reputation and Image in the Global Marketplace, Wipo economics \& statistics series, Geneva.

Wooldridge, J. M. (2002), Econometric Analysis of Cross Section and Panel Data, The MIT press.

Yoo, B., Donthu, N. and Lee, S. (2000), 'An Examination of Selected Marketing Mix Elements and Brand Equity', Journal of the Academy of Marketing Science 28(2), $195-211$. 



\section{Valorization}

The scientific relevance of this thesis is outlined in more detail in the concluding discussion of Chapter 6. This chapter aims to illustrate the social and economic relevance of the research findings in addition to its scientific relevance. The social and economic relevance of dissertations in other disciplines like those from natural sciences become particularly apparent from their contribution to the development of new product and services, new processes or commercial activities.

The four empirical studies that constitute the scientific core of this thesis investigate the behaviour of firms in the German business sector with respect to their use of the trademark system, investment in brands and other intangible assets as well as the performance of these firms with respect to sales with product innovations, firm profitability and productivity. In short, the empirical investigations of this thesis deepen the understanding about the impact of brands on innovation and firm performance. This understanding does not directly lead to new products or commercial activities. It is, however, relevant not only for the scientific discourse but also particularly for managers and policy makers.

Managers can use the empirical findings about the behaviour of firms with regard to branding in their own decision process. Policy makers are responsible for efficient institutions, like the institutional functioning of the trademark system and their effect on market outcomes. They are interested in measures to improve the ability of firms to innovate, to enhance international competitiveness of firms, and to increase productivity growth. In this regard, the empirical findings of the four scientific studies provide some implications for managers and policy makers.

\section{Which Firms Use Trademarks - and Why?}

The first scientific study (presented in Chapter 2) consists of two parts. The first part analyses how many firms make use of the trademark system by registering at least one trademark at the German (DPMA) or European (OHIM) trademark office. The study provides extrapolated figures to the total firm population in Germany by industry and size classes. This kind of information is not available in official statistics from the trademark offices. The statistics of the trademark office are restricted to information from the offices administrative data. The published statistics contain detailed information about the number of applications, the proportion of applica- 
tions that are registered or the duration between application and registration. The link to basic firm characteristics however is not available but necessary to investigate which kind of firms use the trademark system and which are not. Chapter 2 addresses this gap.

The results provide empirical evidence to what extent German firms use trademarks to legally protect their brands and what determines their decision to do so. It is shown that the proportion of trademarking firms in the German business sector amounts to just $18 \%$. This figure is quite low, given that nearly each firm has its reputation to protect, which leads to question what kind of firm actually apply for trademark protection. The empirical evidence shows that firms use trademarks to overcome the distance to their customers, differentiate their products against those from competitors, and that product innovations in particular are associated to trademark registrations. The association between trademark registrations and product innovation is good news for policy makers that are interested in monitoring innovation activities. Trademark registrations might serve as a complementary indicator for (product) innovations to monitoring innovation.

An early draft of the chapter has been presented to a non-scientific auditorium of managers and lawyers in London. ${ }^{18}$ The unique information provided has been of relevance for managers as well as for lawyers. Especially the lawyers achieved a better understanding about the firms that use the trademark system. A trademark attorney can learn about the profile of (potential) customers. Managers on the other hand might reconsider whether their firm fits into the profile of trademarking firms and whether it already has a reputation to protect.

\section{The Impact of Brand Use on Innovation Performance}

The second study, which is presented in Chapter 3, analyses the impact of brand-use on a firm's innovation performance. The central message of the study is that the success of a firm's innovation strategy has two dimensions: First, the ability of a firm to master the research and development process, leading to the market introduction of a product innovation. Second, the ability to turn the market introduction of a product innovation into commercial success. While a firm's technological capabilities are conducive for developing a product innovation, the new product might face a lack of interest among potential customers after its market introduction. The introduction of a product innovation under an established brand name can make the difference.

The research findings are highly relevant for managers as well as for policy makers. Managers are responsible for the economic success in terms of firm profitability. Given that a large proportion of product innovations fail and that these innovations

\footnotetext{
${ }^{18}$ IBC Legal Conference "European Trademarks 2012 - Latest Developments \& Trends Across Europe"
} 
are soon withdrawn from the market, the tools to improve the probability of commercial success are crucial. One strategic management tool is the building of brand equity. A brand might generate interest, add credibility and reputation and has the potential for the firm to better appropriate the returns from its innovations. The results show that managers can improve the odds of commercial success by pursuing a branding strategy. The market introduction of a product innovation is shown to be associated with 35\% larger sales if the firm uses an established brand to introduce the product innovation into the market.

Policy makers should also be interested in the research results since the findings suggest that a functioning trademark system helps innovating firms and strengthens the international competitiveness of these firms. The public funding of R\&D projects might take into account the fact that branding improves the probability of commercial success. If policy makers want to choose the most promising R\&D project proposals, they should consider a firm's established brands in the selection process. Policy could also encourage innovators to establish reputation and to pursue a branding strategy. One could alternatively argue, that a firm that can make use of an established brand achieves a higher expected value of its product innovations and is better able to appropriate the returns to its innovation activities. Since a higher degree of appropriation goes hand in hand with a lower degree of knowledge spillovers, public funding could be reduced.

\section{Investments in Brand Equity and Firm Profitability}

The study presented in Chapter 4 investigates the relationship between brandrelated investments and firm profitability. While famous global brands like Apple, Coca-Cola or Google are highly valuable in terms of their contribution to firm profitability, a manager of an 'average firm' cannot easily copy the branding strategy of these global players. An average firm is much smaller and relies on much smaller resources. The management decision to establish a brand in the marketplace implies nonetheless a significant investment in brand building activities. Whether this investment pays off for an average firm is not obvious a priori.

The empirical findings for a representative sample of German firms show that past brand-related investments contribute to current profits. Brand-related investments are measured by the flow of trademark registrations over the past thirty years. The results show an inverse U-shaped profile of brand-related investments. On average, it takes four years until brand-related investments show a positive return, and twelve years until their return peaks. Investments older than twenty-three years have no significant impacts anymore.

While many attempts to establish a brand in the marketplace might fail, the study provides empirical evidence for managers that brand-related investment pays-off -? at least on average. Managers, however, have to be aware that the building of a 
brand is a long-term investment and that it might takes years until brand contribute to profits.

\section{Intangible Assets and Productivity}

The last study, presented in Chapter 5, investigates the role of intangible assets on firm productivity. The role of intangible assets is of interest not only for managers but also for policy makers. The weak growth performance in European countries since the beginning of the nineties, lead to the Lisbon strategy of the European Union in 2000 with the aim to make the EU "the most competitive and dynamic knowledge-based economy in the world". The Lisbon strategy has recently been replaced by the new strategy for smart, sustainable and inclusive growth for high levels of employment, productivity and social cohesion, called Europe 2020. It is the EU's declared objective of this initiative to reap benefits from the knowledge economy. One important change that has taken place in the new initiative is the acknowledgement that knowledge capital is more than R\&D: it also includes other types of intangible capital such as design and licenses, computerized information, brand equity, firm-specific human capital, and organizational capital.

The study explores to what extent different kinds of intangible assets are conducive to firm-level productivity by simultaneously comparing productivity effects of innovative capital, human capital, branding capital and organizational capital and testing whether complementarity or substitutability exists between different intangible assets. The empirical findings confirm strong positive productivity effects of human capital and branding capital. Results for innovative capital are found to be mixed. While R\&D has a strong positive impact on productivity, design \& licenses and patents show only weak productivity enhancing effects. The same holds for organizational capital. The study also provides evidence that innovative capital and branding capital are complements. For managers this result provides strong evidence that innovation alone is not enough and that firms need to invest in branding and human capital as well to optimally exploit their potential. For policymakers this again stresses the need to maintain a well-functioning trademark system. 


\section{Curriculum Vitae}

\section{Dirk Crass}

Dirk Crass was born on August 21, 1977 in Limburg an der Lahn, Germany. He attended comprehensive school between 1984 and 1994 at the Freiherr-vom-Stein Schule in Hünfelden and high school (Gymnasium) between 1994 and 1997 at the Peter-Paul-Cahensly Schule in Limburg an der Lahn.

He studied Economics at the Goethe University of Frankfurt am Main with main focus on microeconomics, industrial organisation in particular. In his diploma thesis, he analysed the competition regarding the internet backbone market. Subsequently, he studied Quantitative Economics at the Frankfurt University and obtained his Master of Science in Quantitative Economics in 2010. His master thesis is entitled "Regional Labour Markets - Determinants and Forecasts". At that time, he was working as a researcher at the "Institut für Wirtschaft, Arbeit und Kultur (IWAK)" in Frankfurt/Main.

After graduation in 2008, Dirk joined the Department of Industrial Economics and International Management at the Centre for European Economic Research (ZEW) in Mannheim as a researcher. He was a visiting researcher at the Imperial College Business School in London in the UK in 2011 and at Robert H. Smith School of Business, Management \& Entrepreneurship of the University of Maryland in the US in 2012 . 
UNITED NATIONS UNIVERSITY

\section{UNU-MERIT}

\section{4}

\section{Dirk Crass}

The Impact of Brands on Innovation and Firm Performance: Empirical Evidence from Germany

\section{Samyukta Bhupatiraju}

The Geographic Dimensions of Growth and Development

\section{François Lafond}

The evolution of knowledge systems

\section{Annalisa Primi}

Promoting Innovation in Latin America: What Countries Have Learned (and What They Have Not) in Designing and Implementing Innovation and Intellectual Property Policies

\section{Fatoumata Lamarana Diallo}

Evaluation of Meal and Deworming Programs for Primary Schools in Rural Senegal

\section{3}

\section{Anant Kamath}

Information Sharing through Informal Interaction in Low-Tech Clusters

\section{Flavia Pereira de Carvalho}

What we talk about when we talk about Brazilian Mulitantionals: an investigation on Brazilian FDI, economic structure, innovation and the relationship between them

\section{Jun Hou}

Complementarity in Innovation and Development: A Cross-country Comparison

\section{Rufin Baghana}

Impacts of Government Incentives to R\&D, Innovation and Productivity:

A Microeconometric Analysis of the Québec Case

\section{Lilia I. Stubrin}

High-Tech Activities in Emerging Countries: A Network perspective on the Argentinean biotech activity

\section{2}

\section{Abdul Waheed}

Innovation Determinants

and Innovation as a Determinant:

Evidence from Developing Countries

\section{Bilal Mirza}

Energy Poverty and Rural Energy Markets in Pakistan

\section{Benjamin Engelstätter}

Enterprise Software and Video Games: An Empirical Analysis

\section{Fulvia Farinelli}

Natural Resources, Innovation and Export Growth: The Wine Industry in Chili and Argentina

\section{Rodolfo Lauterbach}

Innovation in Manufacturing: From Product Variety and Labor Productivity Growth to Economic Development in Chile

\section{Kirsten Wiebe}

Quantitative Assessment of Sustainable Development and Growth in Sub-Saharan Africa.

\section{Julio Miguel Rosa}

Organizational Strategies, Firms' Performance and Spatial Spillovers. The Canadian Case in Research and Development.

\section{Johannes Wilhelmus Marie Boels} Joseph Schumpeter, honderd jaar economische ontwikkeling. Een historisch-theoretische beschouwing.

\section{1}

\section{Daniel Vertesy}

Interrupted Innovation: Emerging economies in the structure of the global aerospace industry.

\section{Tina Saebi}

Successfully managing alliance portfolios: an alliance capability view. 
70. Nora Engel

Tuberculosis in India - A case of innovation and control.

\section{Evans Mupela}

Connectivity and growth in Sub-Saharan Africa: The role of communication satellites

\section{Nantawan Kwanjai}

Cross cultural intelligence amid intricate cultural webs: A tale of the UnDutchables in the land of 1002 smiles

\section{Lina Sonne}

Innovation in Finance to Finance Innovation: Supporting pro-poor entrepreneur-based innovation

\section{0}

\section{Fernando Santiago}

Human Resources Management Practices and Learning for Innovation in Developing Countries: Pharmaceutical Firms in Mexico

\section{Zakaria Babutsidze}

Essays on Economies with Heterogenous Interacting Consumers

\section{Bertha Vallejo}

Learning and Innovation Under Changing Market Conditions: The Auto Parts Industry in Mexico

\section{Donatus Ayitey}

Technical Change, Competitiveness and Poverty Reduction: A Study of the Ghanaian Apparel Industry

\section{Sergey Fillipov}

Multinational Subsidiary Evolution: Corporate Change in New EU Member States

\section{Asel Doranova}

Technology Transfer and Learning under the Kyoto regime; Exploring the Technological Impact of CDM projects in developing countries
2009

\section{Alexis Habiyaremye}

From Primary Commodity Dependence to Diversification and Growth". "Absorptive Capacity and Technological Catch Up in Botswana and Mauritius".

\section{Yoseph Getachew}

The Role of Public Capital in Economic Development

\section{Sandra Leitner}

Embodied Technological Change and Patterns of Investment in Austrian Manufacturing

\section{Semih Akçomak}

The Impact of Social Capital on Economic and Social Outcomes

\section{Abraham Garcia}

The Role of Demand in Technical Change

\section{Saurabh Arora}

Coherence in socio-technical systems: a network perspective on the innovation process

\section{8}

\section{Rutger Daems}

Medicines for the developing world

\section{Johannes Hanel}

Assessing Induced Technology: Sombart's Understanding of Technical Change in the History of Economics

\section{Rifka Weehuizen}

Mental Capital: the economic significance of mental health

\section{Danielle Cloodt}

The relationship between R\&D partnership formation, social embeddedness and innovative performance

50. Sabine Fuss

Sustainable Energy Development under Uncertainty 
2007

\section{Tobias Kronenberg}

Reconciling Environmental Conservation with Economic Prosperity: The Feasibility of Double Dividends in the Short and Long Run

\section{Viktoria Kravtsova}

Assessing the Impact of Foreign Direct Investment in Transition Economies

\section{Suhail Sultan}

The Competitive Advantage of Small and Medium Sized Enterprises: The Case of Jordan's Natural Stone Industry

\section{6}

\section{Bulat Sanditov}

Essays on Social Learning and Imitation

\section{Mamata Parhi}

Dynamics of New Technology Diffusion: A Study of the Indian Automotive Industry

\section{Andreas Reinstaller}

Social structures and the innovation process: Their role in the demand of firms and consumers

\section{Rose Kiggundu}

Innovation systems and development: the journey of a Beleaguered Nile Perch Fishery in Uganda

\section{Thomas Pogue}

The Evolution of Research Collaboration in South African Gold Mining: 1886-1933

\section{Geoffrey Gachino}

Foreign Direct Investment, Spillovers and Innovation: The Case of Kenyan Manufacturing Industry

\section{0. Önder Nomaler}

Technological Change, International Trade and Growth: An Evolutionary, Multi-Agents-Based Modeling Approach

\section{5}

\section{Samia Satti Osman Mohamed-Nour} Change and Skill Development in the Arab Gulf Countries

\section{Elad Harison}

Intellectual Property Rights: Economics and Policy Analysis

\section{Daniel Dalohoun}

The relationship between R\&D partnership formation, social embeddedness and innovative performance: a multi-level approach of social embeddedness

\section{Müge Ozman}

Networks, Organizations and Knowledge

\section{Bas Straathof}

Product variety and economic growth: The counteracting effects of scale and idiosyncrasy

\section{Wilfred Schoenmakers}

Knowledge Flows between Multinational Companies: A Patent Data Analysis

\section{Myriam Cloodt}

Mergers and Acquisitions (M\&As) in High-Tech Industries: Measuring the Post-M\&A Innovative Performance of Companies

\section{4}

\section{Paola Criscuolo}

R\&D Internationalisation and Knowledge Transfer. Impact on MNEs and their Home Countries

\section{Maarten Verkerk}

Trust and Power on the Shop Floor

\section{Gottfried Leibbrandt}

Adoption, harmonization and succession of network technologies across countries

\section{Mark Sanders}

Skill Biased Technical change - Its Origins, the Interaction with the Labour Market and Policy Implications

\section{3}

\section{Nadine Roijakkers}

Inter-firm cooperation in high-tech industries: a study of R\&D partnerships in pharmaceutical biotechnology

\section{Viki Sonntag}

Speed, Scale and Sustainability 
26. Masaru Yarime

From End-of-Pipe Technology to Clean Technology

\section{Stéphane Malo}

The combinatorial Chemistry Revolution -

Sustaining a Superior Performance Position through Technological Learning

\section{2}

24. Annelies Hogenbirk

Determinants of Inward Foreign Direct Investment: the Case of the Netherlands

\section{1}

\section{John Adeoti}

Technology Investment in Pollution Control in SubSaharan Africa: The Case of the Nigerian

Manufacturing Industry

\section{Edward Huizenga}

Innovation Management: How Frontrunners Stay Ahead. An Empirical Study on Key Success Factors in the ICT sector

\section{0}

\section{Machiel van Dijk}

Technological Change and the Dynamics of Industries. Theoretical Issues and Empirical evidence from Dutch Manufacturing

1999

\section{Jan Cobbenhagen}

Managing Innovation at the Company Level: A Study on Non-Sector-Specific Success Factors

\section{Marjolein Caniëls}

Regional Growth Differentials: The Impact of Locally Bounded Knowledge Spillovers

\section{8}

\section{Aldo Geuna}

Resource allocation and knowledge production: Studies in the economics of university research

\section{6}

\section{Reinoud Joosten}

Dynamics, Equilibria, and Values

\section{Hugo Kruiniger}

Investment, R\&D, and the Financing Decisions of the Firm

\section{5}

\section{Hans van Meijl}

Endogenous Technological Change: The Case of Information Technology. Theoretical Considerations and Empirical Results

\section{René Kemp}

Environmental Policy and Technical Change. A Comparison of the Technological Impact of Policy Instruments

\section{Rohini Acharya}

The Impact of New Technologies on Economic Growth and Trade. A Case Study of Biotechnology

\section{Geert Duysters}

The Evolution of Complex Industrial Systems. The Dynamics of Major IT Sectors

\section{Marjan Groen}

Technology, Work and Organisation, A Study of the Nursing Process in Intensive Care Units

\section{4}

\section{Huub Meijers}

On the Diffusion of Technologies in a Vintage Framework; Theoretical Considerations and Empirical Results

\section{Theon van Dijk}

The Limits of Patent Protection. Essays on the Economics of Intellectual Property Rights

\section{Hans Voordijk}

Naar Integrale Logistiek in Bedrijfsketens, Ontwikkelingen in de Bouw 
1993

\section{Paul Diederen}

Technological Progress in Enterprises and Diffusion of Innovations. Theoretical Reflections and

Empirical Evidence.

\section{Ben Dankbaar}

Economic Crisis and Institutional Change. The crisis of Fordism from the perspective of the automobile industry

\section{Hanno Roberts}

Accountability and Responsibility: The Influence of Organisation Design on Management Accounting

\section{2}

\section{Bart Verspagen}

Uneven Growth Between Interdependent

Economies. An Evolutionary View on Technology

Gaps, Trade and Growth

\section{Sjoerd Romme}

A Self-organization Perspective on Strategy

Formation

1989

\section{John Spangenberg}

Economies of Scale, and Atmosphere in Research Organisations

\section{8}

\section{John Hagedoorn}

Evolutionary and heterodox innovation analysis: a study of industrial and technological development in process control and information technology 